Andrea Aparecida Cavinato

\title{
Uma experiência em Teatro e Educação: a história do menino navegador llo Krugli e seu indomável Ventoforte
}

Dissertação apresentada ao Departamento de Artes Plásticas da Escola de Comunicações e Artes da Universidade de São Paulo como exigência parcial para a obtenção do título de Mestre em Artes, sob a orientação da Prof.. D Dr. ${ }^{\text {a }}$ Regina Stela Barcelos Machado.

Universidade de São Paulo.

Escola de Comunicações e Artes

São Paulo

2003 
Andrea Aparecida Cavinato

\section{Uma experiência em Teatro e Educação: a história do menino navegador llo Krugli e seu indomável Ventoforte}

Dissertação apresentada ao Departamento de Artes Plásticas da Escola de Comunicações e Artes da Universidade de São Paulo como exigência parcial para a obtenção do título de Mestre em Artes, sob a orientação da Prof.. Dr. ${ }^{\text {a }}$ Regina Stela Barcelos Machado.

Universidade de São Paulo.

Escola de Comunicações e Artes

São Paulo

2003 
Comissão julgadora:

Prof. ${ }^{\text {a }}$ Dr. ${ }^{-}$Maria Lúcia Souza Barros Pupo

Prof. ${ }^{a}$ Dr. ${ }^{a}$ Miriam Celeste Ferreira Dias Martins

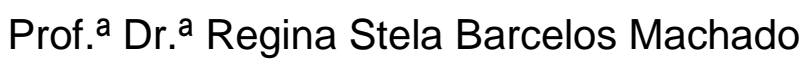




\section{Resumo}

Uma experiência em Teatro e Educação: a história do menino navegador llo Krugli e seu indomável Ventoforte, dissertação de Mestrado de Andrea Aparecida Cavinato, sob orientação da Prof. a Dr. ${ }^{\text {a }}$ Regina Stela Barcelos Machado, tem como objetivo de pesquisa situar e aprofundar a reflexão sobre as manifestações estética-pedagógicas do grupo de teatro Ventoforte a partir da visão de mundo da figura central do grupo: llo Krugli. A elaboração da pesquisa contou com pesquisa histórica, entrevistas, depoimentos e ancorou-se na experiência e observação pessoal. Foram desenvolvidos conceitos da proposta estética e pedagógica do grupo relacionada à aprendizagem em Arte; uma cronologia e o mapeamento das confluências que forjaram a linguagem cênica do Ventoforte, que nos seus 28 anos de trajetória, insere-se no contexto da contemporaneidade identificado a movimentos e idéias modernistas e no melhor devir dos ideais propostos por estes. O diretor llo Krugli e seu Ventoforte mantêm sua proposta de encenação, agora, uma marca registrada do grupo. 


\begin{abstract}
An experience on theatre and education: the story of the navigator boy llo Krugli and his indomitable "Ventoforte" (strongwind), master degree essay of Andrea Aparecida Cavinato, under orientation of Regina Stella Barcelos Machado. This essay has as research aim to place and deepen the reflexion about the manifestations aesthetic pedagogical of the theatre group "Ventoforte" according to the world's vision of the main and central figure of the group: llo Krugli. The elaboration of this research relied on historical research, interviews, testimonies and has anchored on personal experience and observation. Concepts about the aesthetic and pedagogical proposals of the group related to the process of art learning were developed; a chronology and the maping of the confluences which produced the scenic language of Ventoforte, which in its 28 years of course, sets itself in the contemporary context identified to ideas and movements of the modernism and in the best consequences of the ideals proposed by these. The director Ilo Krugli and his "Ventoforte" maintains his proposal of mise-en-scène, now, a trade mark of the group.
\end{abstract}




\section{Agradecimentos}

Muitas foram as pessoas que contribuíram para a realização desse trabalho. São tantas e todas elas tão importantes que temo não conseguir dar o nome a todas. Inicio agradecendo ao pessoal do grupo Ventoforte, todos aqueles que passaram por lá e os que permanecem.

À Prof. ${ }^{a}$ Dr. ${ }^{a}$ Regina Machado, professora-artista, minha orientadora, que desde o princípio, incentivou e acolheu a idéia do projeto, valorizando sempre a importância do seu desenvolvimento.

Às Prof. $\stackrel{a}{\text { Dr.a }}$ Miriam Celeste Ferreira Dias Martins e à Prof. ${ }^{a}$ Dr. ${ }^{\text {a }}$ Maria Lúcia de Souza Barros Pupo pelas valiosas sugestões no exame de qualificação.

E, ainda, à Prof..$^{\text {a }}$ Dr. ${ }^{\underline{a}}$ Maria Lúcia de Souza Barros Pupo e ao grupo da disciplina Prática de Ensino II, pela convivência no Programa de Aperfeiçoamento de Ensino (PAE).

Aos professores da pós-graduação llíada Castro, Clóvis Garcia, Fausto Fuser, José Eduardo Vendramini, Ana Mae Barbosa, Cristina Rizzi, Marco Antônio Guerra e Marina Célia Moraes Dias.

A João Coin de Carvalho, pelas correções e dicas no projeto de pesquisa.

Ao amigo Rui Weber, a quem acordei várias vezes para me ajudar com o computador. 
À Luciana Coin, que me apresentou o Ventoforte, e Paulo da Rosa, colegas do curso para crianças e adolescentes, que sempre me ajudaram com informações e sugestões, participando ativamente da construção da pesquisa.

À Lindalva Souza, que valoriza meu trabalho, meu agradecimento sincero.

À Mariana Corollon, Mônica Huambo, Tatiana Bichara, Paulo Farah André, Fátima Campidelli, Paulo César Brito, Oswaldo Gabrielli, Wilton Amorim, Révero Ribeiro, Selma Bustamante, Edgar Lippo, Beto Andreeta, Henrique Sitchin, Ronaldo Mota, Laurent Matari, Luiz Carlos Laranjeiras, Marina Marcondes Machado e todos que contribuíram com seus depoimentos.

À Rosa Comporte, Lígia Catunda e Tião Carvalho, pelas entrevistas.

À Fátima Ortiz, pelo depoimento, Hector Girondo, do Teatro de la Plaza pela ajuda com a pesquisa em Buenos Aires sobre Javier de Villafãne.

A Roberto Melo e Fábio Viana pelas fotos e tudo mais, do arquivo do grupo Ventoforte.

Vera Alejandra pela tradução para o inglês.

Aos colegas da pós-graduação Rogério Moura e Lelê Ancona, que inspiraram caminhos à minha frente. 
À Safira Lyra de Moraes, que acompanhou as batalhas travadas para a conquista desta e de outras realizações.

Ao Marcos Coin, companheiro de todas as horas.

E a llo Krugli, mestre querido, protagonista da história que aqui vou contar. 
"Saúdo a todos que me lerem, tirando-Ihes o chapéu largo Quando me vêem à minha porta Mal a diligência levanta de cima do outeiro. Saúdo-os e desejo-Ihes sol, E chuva, quando a chuva é precisa,

E que suas casas tenham Ao pé duma janela aberta Uma cadeira predilecta Onde se sentem, lendo os meus versos. E ao lerem os meus versos pensem Que sou qualquer cousa natural Por exemplo, a árvore antiga À sombra da qual as crianças Se sentavam com um baque, cansados de brincar, E limpavam o suor da testa quente Com a manga do bibe riscado".

Alberto Caeiro 


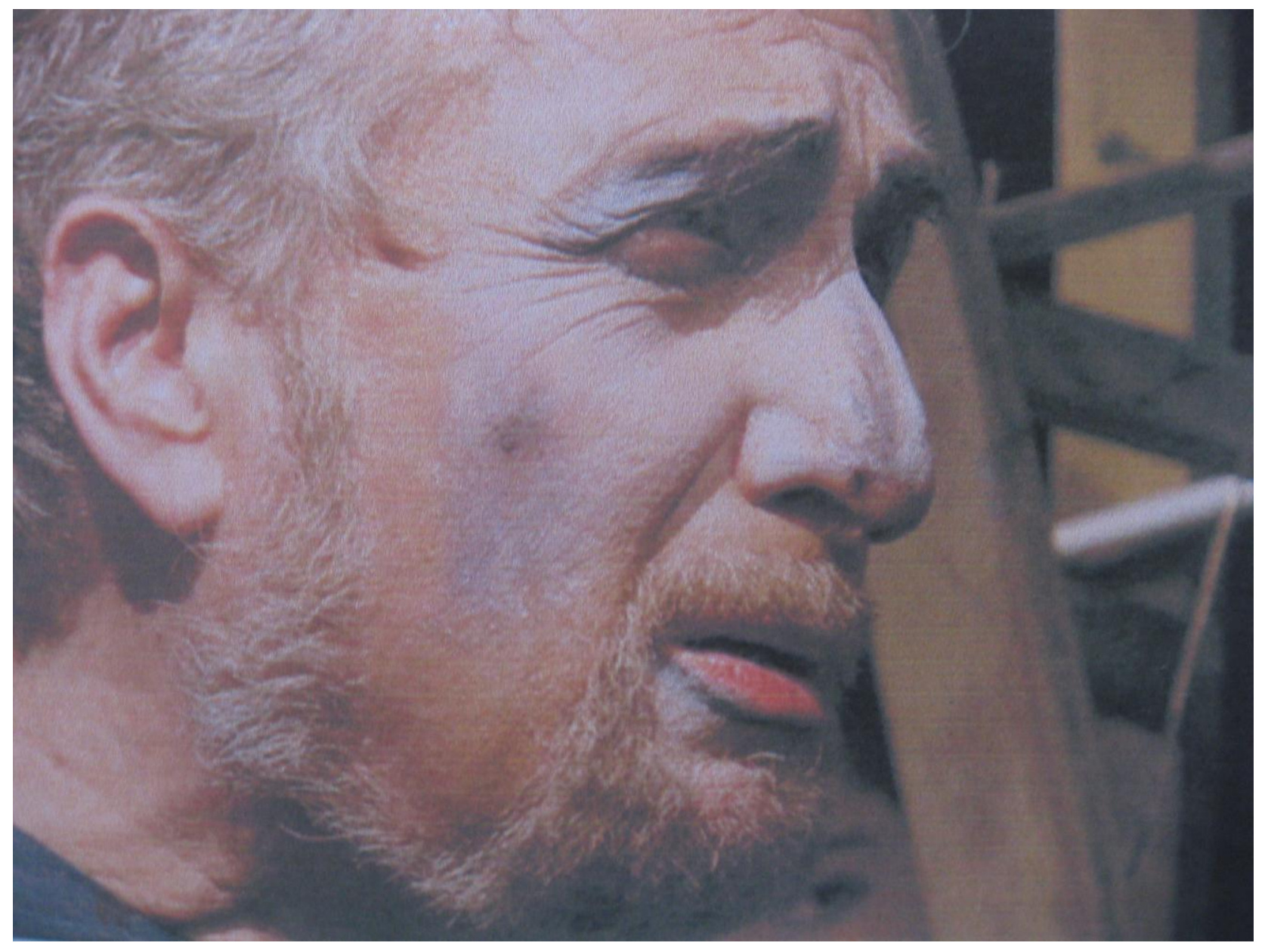

Ilo Krugli. Portal das Maravilhas. Foto: Gil Grossi. 


\section{SUMÁRIO}

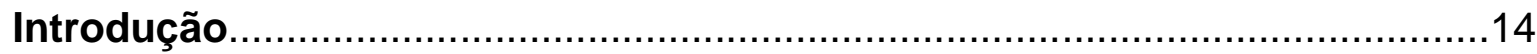

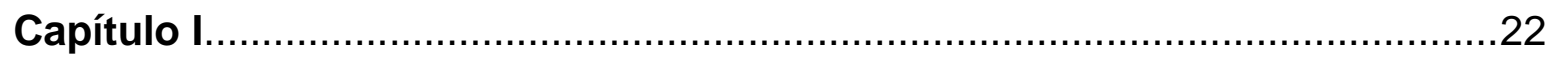

\section{Era uma vez um menino navegador}

Uma espécie de auto biografia.

Onde se conta sobre:

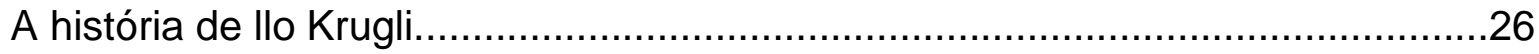

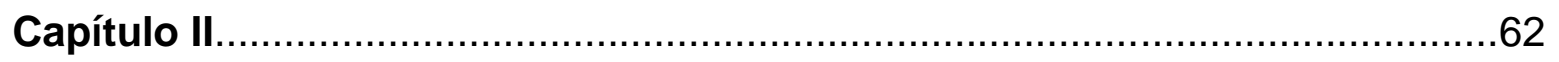

\section{Que enfrentou Quatro Portas...}

Contextualização histórica do grupo Ventoforte

Onde se conta sobre:

A tradição do teatro andarilho............................................................66

- $\quad$ Aspectos políticos, culturais e estéticos no caminho histórico do grupo

Teatro Ventoforte:

- Influência do trabalho da Dr. ${ }^{\stackrel{a}{ }}$ Nise da Silveira.....................................71

- A importância da cultura popular.....................................................73

- Uma possível relação com a proposta da Bauhaus...............................83

- $\quad$ A tendência da livre expressão e o Movimento Escolinhas de Arte........89

- $\quad$ Cronologia de llo Krugli e seu indomável Ventoforte..............................91

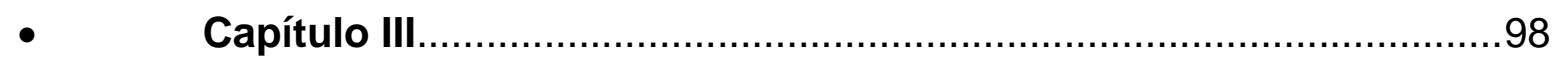

\section{A porta da Terra e do Fogo...}

Aspectos da proposta pedagógica do grupo Ventoforte.

1. Onde se conta sobre: 
- $\quad$ Conceito de ensino da Arte em relação ao Movimento Escolinha de Arte 103

- A concepção de um teatro para crianças 114

- $\quad$ Cursos para crianças, adolescentes e adultos

2. Onde se conta sobre:

- A concepção de teatro para crianças em diálogo com idéias formadoras: a livre-expressão e o movimento Escolinhas de Arte do Brasil...........................127

Capítulo IV. .138

\section{A porta da Água e do Ar}

- $\quad$ Aspectos da proposta estética do grupo Ventoforte

- $\quad$ Manifestação estética: Forma teatral do grupo de llo Krugli para crianças de todas as idades

- $\quad$ O que é fazer Arte para criança segundo Ilo Krugli.............................142

- Compreensão de aprendizagem estética.............................................161

- $\quad$ Espetáculo Histórias que o Eco Canta...............................................163

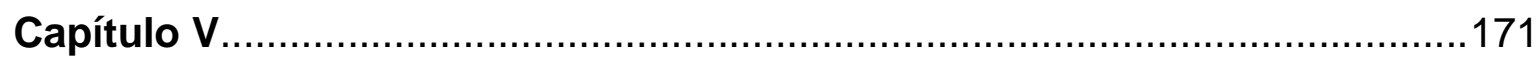

E que entregou as quatro chaves para outras pessoas

- Desdobramentos

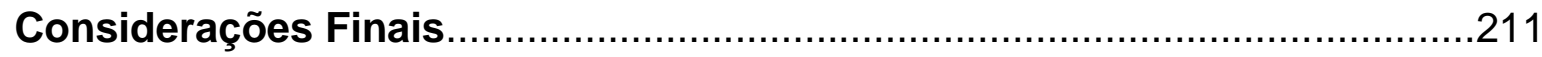

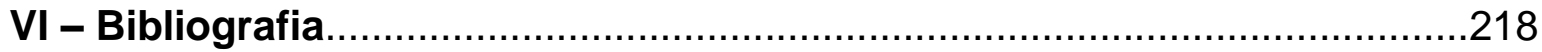

VII - Anexos:

1. Depoimentos 2. Manuscrito da peça Histórias que o Eco Canta 3. Folheto da Feira de teatro e capa do Livro de Javier. 4. Capa do programa de Histórias de Fuga, Paixão e Fogo. 5. Folheto de divulgação. 6. Cartaz O Rio que vem de longe. 7. Foto: Ilo Krugli: O rio que vem de longe. Foto Gil Grossi. 8. Convite para comemoração do aniversário do grupo.

\section{Errata}

Erramos: No sumário na página 12, por favor considerar apenas o item número 2 e no capítulo III na página 135 na nota de rodapé a citação é "idem" a nota 33 e não "idem" a 31. 


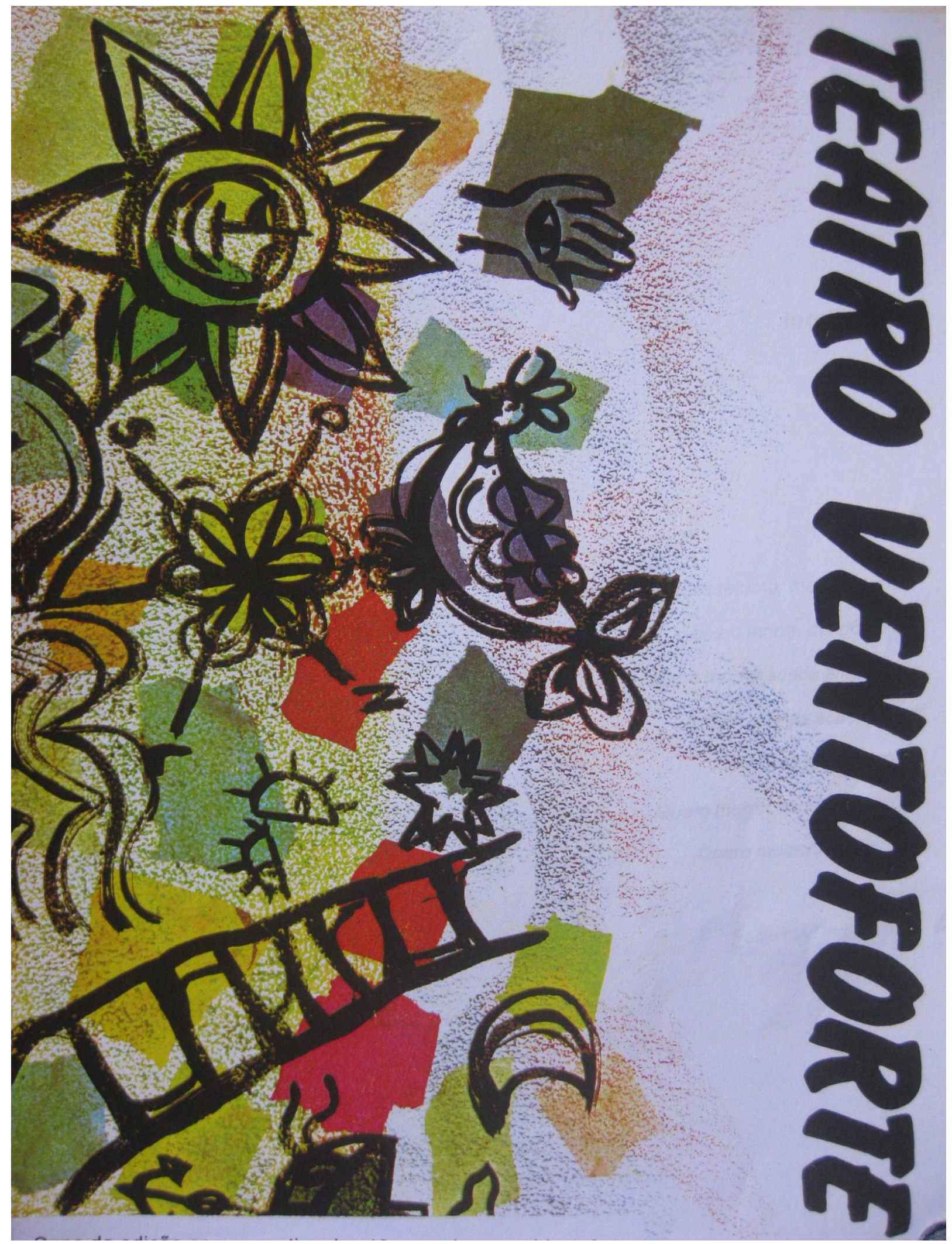

Capa da edição comemorativa dos 10 anos do grupo Ventoforte 


\section{Introdução}

"Por minhas asas retorno, me deixe voltar

Quero morrer sendo ontem

Quero morrer sendo amanhecer

Por minhas asas retorno

Me deixe voltar

Quero morrer sendo manancial

Quero morrer fora do mar"

Federico Garcia Lorca 
Três pancadas na madeira, vela acesa, os atores e músicos estão prontos: a função vai começar.

— Respeitável público: crianças, damas e cavalheiros!

As cortinas já estão abertas, são vários os cortinados. O palco da história são muitos: vãos de escadas, caminhões, carroças, barracões, portas de igreja, praças e o próprio teatro. A peça conta a história de gente de teatro, de poesia, da Arte, da aprendizagem através da Arte.

Olho pelos cortinados, com olhos da memória, com olhos de menina, com olhos de pesquisadora. Exercendo o ofício que escolhi trago as imagens do meu aprendizado em Arte, junto ao levantamento histórico de críticas e matérias de jornal, depoimentos, entrevistas e o diálogo com autores, reflexões. Abro as cortinas para contar o que vi, li, refleti e recolhi sobre llo Krugli e o grupo de Teatro Ventoforte.

- Respeitável público, aí vêm os atores e músicos cantando, carregando seus bonecos...

\author{
Ai girassol, \\ ai girassol de fogo, \\ ai girassol, \\ ai cravinhos do sol, \\ e no bico uma flor e na flor uma oliva, \\ e na oliva um limão,
}




$$
\begin{gathered}
\text { ai girassol, } \\
\text { girassol da manhã, } \\
\text { ai cravinhos do sol. }{ }^{1}
\end{gathered}
$$

Eu, mestre de cerimônias, aqui peço licença aos donos da casa para abrir as cortinas e introduzi-los às coxias, às salas de aula, aos processos de criação que antecedem aos espetáculos, aos caminhos que fundem obra e vida. Quero que vejam através do meu relato alguns trechos de alguns desses mesmos espetáculos.

Conheci llo Krugli em 1990, como professor do curso Teatro da Imaginação. Eu era então sua aluna, vinda de Limeira, onde havia feito teatro amador para cursar Terapia Ocupacional na USP.

Muito tímida, participava incrédula das aulas em um barracão enfeitado com panos lilases no teto e chão de madeira. Ali, a partir das sete da noite, alunos se movimentavam pela sala ao som de músicos que tocavam ao vivo. Na primeira aula me escondi embaixo da arquibancada. Eu tinha 19 anos.

Naqueles tempos eu já me perguntava como é que ele fazia aquilo. Ele falava esquisito, explicava a proposta da aula sentado no chão junto a uma grande roda de pessoas de idades variadas, acompanhado do cachorro Hércules, alguns gatos, chimarrão. No começo eu não entendia nada, vinha de decorar texto em Limeira e fazer laboratório. Assim que ele terminava de falar, os músicos começavam a tocar e logo os alunos se moviam pela sala rodopiando, se arrastando, se olhavam nos olhos, alguns ofereciam o que traziam tirando do peito um rio, o sol, as estrelas...

1 Letra de F. G. Lorca e llo Krugli, música de Ronaldo Motta. 
Nos finais de semana o barracão denominado Teatro dos Pés abrigava a Tempestade ou o Punhal de Caliban, adaptação do texto de Shakespeare. Quando assisti a peça, ainda em 1990, minha perplexidade cresceu. Pequenino e dançando engraçado, llo Krugli interpretava Próspero, e eu não entendi mesmo muita coisa... Mas as imagens ficaram cravadas em mim em um misto de espanto e de falta de noção de tempo e espaço. Miranda usava uma boneca feita de arame que parecia às vezes um espelho; a cabeça saía do corpo da boneca e se transformava em uma máscara; Caliban cantava batendo num tambor, parecia uma festa. Eu até aqui vira pouquíssimo teatro e nada como este que lembrava um carnaval de rua de antigamente e embora não compreendesse bem, experimentei um sentimento desconhecido, uma emoção, me lembro de uma sensação de nó na garganta!

Inspirada um pouco pelo espetáculo e outro tanto pelos alunos do curso, não demorou muito para que aos poucos achasse que tinha entendido o jeito de se fazer: era dançar daqui, de lá, movimentar o corpo; imaginando que eu era vento, terra, fogo, água. Me esqueci até que, o tempo todo, ele nos via. Eu tinha feito balé em Limeira e me soltei... Nessa e em muitas aulas eu me perguntava como é que ele tinha feito aquilo, eu que era tão tímida estava conseguindo me soltar... Até que, em roda, ele comentou do mal que fazia o balé às meninas do interior... Movimentos estereotipados, algo assim. Todo mundo me olhando... Gelei. Então eu soube que devia existir um certo e um errado, mas como era isso ?

Não perguntei nada, não sabia perguntar. Perguntas e palavras ainda estavam muito distantes de serem conquistadas. A estas primeiras, outras se somaram, sobre a aprendizagem através da Arte, o que era possível aprender? Como ele conseguia a participação das crianças nos espetáculos de maneira tão espontânea e a dos alunos em aulas e oficinas? Quem era, afinal, esse senhor? Como conseguia ser sempre tão próximo da maneira das crianças. 


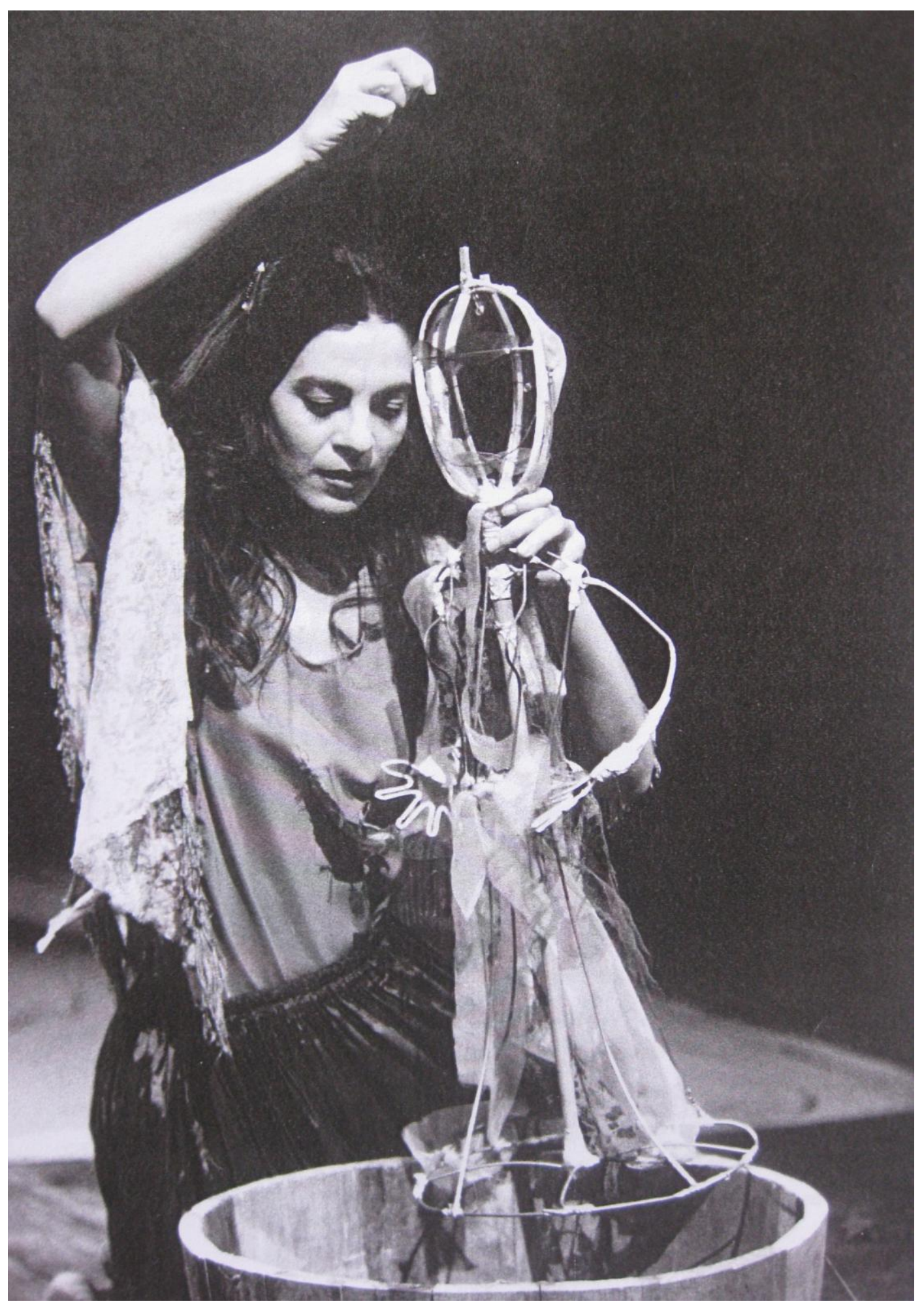

A Tempestade ou o Punhal de Caliban. Rosa Comporte interpreta Miranda. Foto Gil Grossi. Arquivo Rosa Comporte. 
Muitas perguntas foram sendo formuladas; o envolvimento e a paixão necessários para tentar respondê-las surgiram e permanecem. Algumas fui resolvendo nos dez anos na Casa do Ventoforte, tempo de permanência muito curto se comparado ao de integrantes que estão no grupo desde 1980.

Pude perceber, no entanto, nesse período e também para essa pesquisa, a emoção de todos os tipos que a menção do nome llo Krugli e do Ventoforte causam. Bem ao exemplo das forças da natureza: incontroláveis, imprevisíveis... Ventos fortes em geral anunciam belas tempestades. Ilo Krugli é considerado como um grande mestre, que possibilita o contato com a arte de maneira especial, singular e que imprime marcas profundas.

Novas perguntas surgiram quando comecei a dar aulas. Confusas, ainda não tinham forma interrogativa e aos poucos, somado o aprendizado da graduação, da especialização ${ }^{2}$ com a experiência em arte, pude organizá-las em uma só, por enquanto.

$\mathrm{Na}$ tentativa de ir respondendo as várias perguntas contidas em uma, me deparei com as confluências. O bonequeiro argentino Javier de Villafãne é a primeira delas. Mesmo em tempos de internet conseguir trazer da Argentina os livros sobre ele, demonstrou ser uma operação complexa em que várias pessoas estiveram envolvidas. Foi uma verdadeira epopéia encontrar e conseguir uma biografia sua e o primeiro livro que publicou. Quando chegaram da Argentina, mal tirei o livro de Javier da sacola e o desenho da capa me salta aos olhos: a carroça com bonecos, La Andariega com o galinho dos ventos indicando os pontos cardeais. No folheto da feira de teatro Ventosopravento em comemoracão aos 28 anos do teatro Ventoforte, um desenho de Ilo Krugli também mostra uma carroça com o galinho indicando os quatro pontos cardeais, símbolo que representa

2 Graduação em Terapia Ocupacional na USP.

Especialização em Arte-educação na ECA/USP. 
graficamente o grupo. As imagens indicavam um enraizamento em Javier para o qual eu gostaria de continuar olhando. $O$ bonequeiro argentino merecia mesmo minha determinação em importar os livros.

O foco da pesquisa definiu-se por uma aproximação da visão de mundo de llo Krugli e então esmiuçá-la, olhando para sua infância, descobrindo-a nos espetáculos. Conhecer seus pensamentos e conceitos sobre a Arte e a aprendizagem, que se fundem em forma teatral repleta de poesia; investigar ainda de que é feita essa forma teatral e quais são os processos criativos que llo Krugli conduz para chegar aos espetáculos para crianças e adultos; produções poéticas inauguradas para o grande público e para a crítica com Histórias de Lenços e Ventos, em 1974.

O espetáculo que demarcou a história do teatro infantil brasileiro possui a mesma qualidade essencial dos que o seguiram em 28 anos de trajetória do grupo Ventoforte: são momentos de aprendizagem estética. Investigar e desvendar os meandros dessa proposta estética-pedagógica referindo-se, ainda a alguns outros espetáculos, é a aventura para a qual partimos.

Enquanto levantava dados relacionando a visão de mundo de llo Krugli, às formas teatrais desenvolvidas pelo Ventoforte, fui percebendo o que queria investigar: o que faz com que estes espetáculos se tornem momentos de aprendizagem estética? Descobri que essa era a pergunta central do meu trabalho.

Para respondê-la, além da minha própria experiência, contei com entrevistas de llo Krugli e com o depoimento de pessoas que fizeram cursos no Ventoforte. Enquanto desdobramento dessa experiência, em teatro e educação, escolhi algumas pessoas, que tendo passado pelo grupo, deram continuidade a 
uma proposta em arte articulada de forma pessoal e criadora a partir do aprendizado junto ao Ventoforte.

Para Osvaldo Gabrielli, Fátima Ortiz, Fátima Campidelli, Paulo César Brito, para mim (alguns dos exemplos concretos citados nessa dissertação), e certamente para muitos outros, llo Krugli é o mestre que faz com que a chama brilhe e com esse pequenino lume, sempre aceso, possamos encontrar nossos próprios caminhos.

Os caminhos que levam à aprendizagem estética perpassam pelos espetáculos do grupo Ventoforte e se relacionam com o processo conduzido para sua elaboração: da figura do diretor à escolha do texto, da formação dos atores à dramaturgia, dos objetos, à música e o movimento inspirados na cultura popular, destacando-se apenas alguns dos elementos que constituem a linguagem cênica do grupo.

E, claro, uma dose do indecifrável, do oculto, misterioso como cabe à tradição dos poetas e andarilhos. A poesia que nos toca, mas que é impossível de ser realmente explicada. Resta-nos tê-la partilhado e reconhecido.

Três pancadas na madeira, vela acesa, os atores e músicos estão prontos: a função vai começar. Iluminado por candeeiros à querosene e sob a luz das estrelas, Mestre Trotamundos convocava o público para os espetáculos que aconteciam na carroça La Andariega.

— Respeitável público: crianças, damas e cavalheiros!

A função vai começar! 


\title{
Capítulo I
}

\section{Era uma vez um menino navegador}

\author{
"Diga-Ihe. Que pelos sonhos da sua juventude \\ ele deve ter consideração, quando for homem." \\ Schiller
}




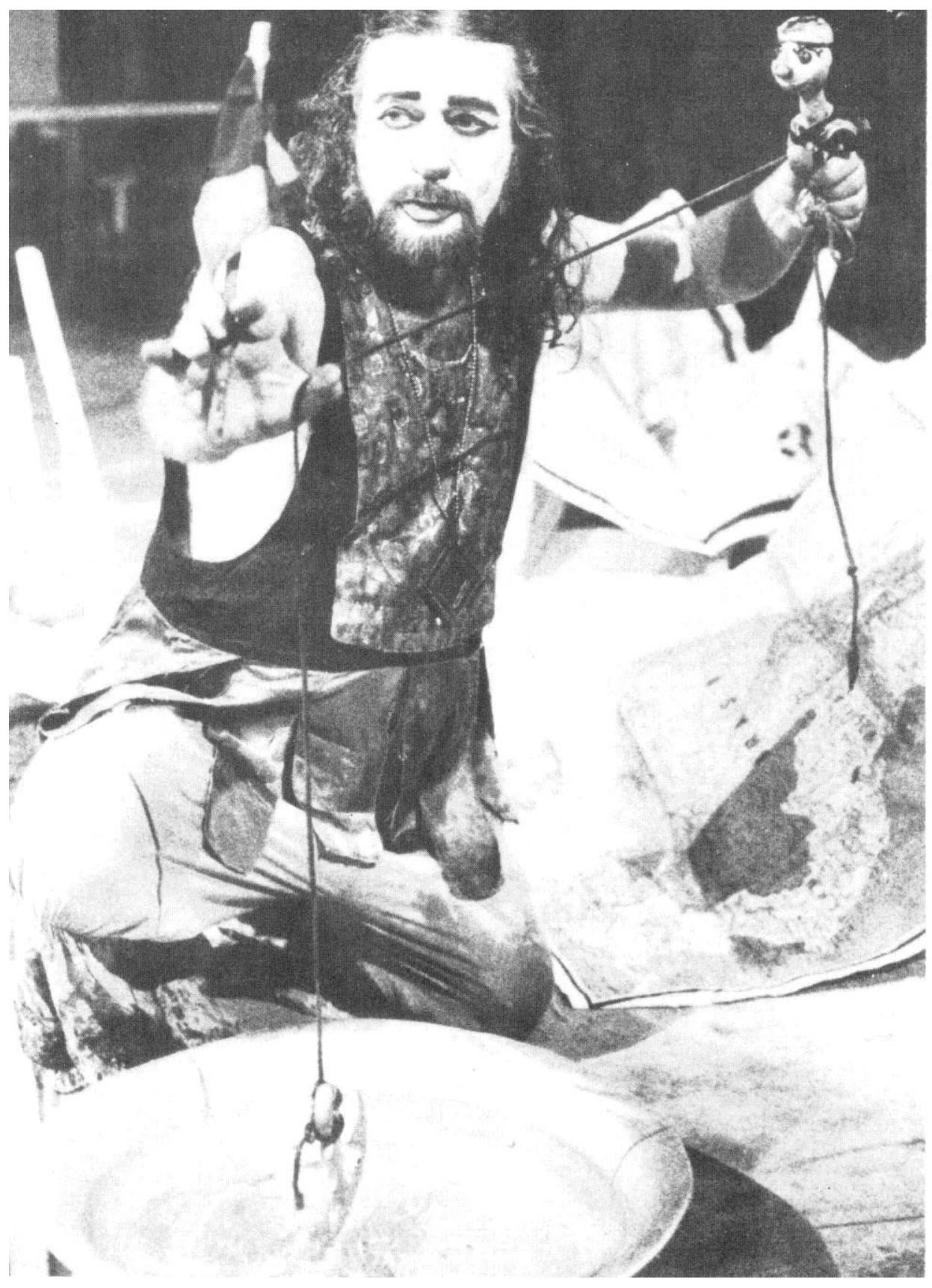

Ilo Krugli. O rio que vem de longe. Foto Gil Grossi. Arquivo Ventoforte 


\section{A entrevista}

Conversar com llo Krugli, para mim, é sempre um misto de aula, trocas, confidências. Sempre um prazer. Suas muitas histórias divertem, ensinam. Nem lembra o diretor enérgico que leva a pulso seus atores na rigorosa arte do teatro. Fala mansa e expressiva, decidida e delicada. Olhos brilhantes, entre suspiros, interjeições e exclamações ele vai contando com preciosa memória e riqueza de detalhes suas histórias...

Vindo da Argentina e naturalizado brasileiro, Ilo Krugli possui um modo de falar e um característico modo de acentuar as palavras que são peculiares. Tentei manter na transcrição essa forma literalmente.

As entrevistas aconteceram na casa de llo, dentro do espaço que abriga a Casa do Ventoforte, e no Teatro do Círculo, um dos barracões transformados em teatro do grande espaço arborizado que o grupo ocupa no bairro do Itaim, na cidade de São Paulo, antes dos ensaios para o espetáculo que estão montando sobre Vítor Hugo. Pelo espaço passam cachorros, gatos. Músicos se aquecem em seus instrumentos, atores montam o espaço de ensaio. No horário de verão ainda há muita luz, filtrada pela treliça das janelas altas do teatro.

Foi elaborado um roteiro de entrevista com perguntas que o levassem a uma autobiografia, à reflexão sobre seu próprio trabalho e uma análise dos percursos do grupo. 
Contudo, llo Krugli foi muito mais além disso, e durante a entrevista conheci o Discurso sobre o brinquedo ${ }^{3}$, poema que leu e no qual relata seus brinquedos durante a vida.

Dessas conversas animadas, sérias e emocionadas que levaram dois dias para serem gravadas, pode-se iniciar o caminho que leva a conhecer o artista por ele mesmo.

Autodidata, freqüentou ateliês na adolescência e aprendeu a fazer bonecos no primário, chegou pronto ao mundo, como ele mesmo diz. Exigente, está sempre aprendendo e idealizando o projeto da sua escola que a realidade ainda não permitiu que fosse mais elaborada...

A arte esteve sempre, desde cedo muito presente em sua vida e contribuiu para definir muitas de suas escolhas, sua coerência, seu rigor nessas escolhas. A manutenção do grupo Ventoforte se deve às suas muitas experiências desde a infância com diferentes grupos.

Sabemos que o teatro é feito da força criadora do trabalho de muitos, às vezes até mesmo anônimos. O grupo Ventoforte se renova praticamente a cada nova temporada, centralizado e impulsionado pela força de seu diretor llo Krugli.

Foi professor em muitas escolas, de tanta gente... Está muito ocupado agora, escrevendo a adaptação para o Vítor Hugo...

Três batidas. O primeiro ato vai começar...

3 Publicado por BOTKAY, Caíque. Achados. Rio de Janeiro: Editora Nova Fronteira, 2002. 


\section{A primeira pergunta é seu nome completo...}

É. Vamos começar por isso. Meu nome completo é llo Krugli!!!! Claro que, nos meus documentos está o Elias Kruglianski que é meu nome civil, jurídico, eu não sei, qualquer coisa assim.

Mas quando eu era pequeno não sei que loucura deu em mim que eu queria, sempre quis mudar de nome, quando eu era pequeno eu queria que me chamassem com o nome de um passarinho, aí meio, aquele bem pardalzinho, coisa assim, mas ele tinha um topetinho e se chamava Tingolo, da onde que eu tirei não sei, existe. Existe lá, e era engraçado. Claro que ninguém quis me chamar por esse nome. Mas sempre, parece que quis mudar, não é? E aí cedo eu mudei de nome.

Também dentro da minha casa eu recebia vários nomes e acho que isso tem a ver até com o nome que eu escolhi. Meu pai me chamava de várias formas. Um nome era Alioshoa, que é russo, meu pai era polonês russo, então Alioshoa, que é um personagem do Dostoiévski, Alioshoa. Me chamavam de llia, Ilich, Eli e Elias, claro, porque é o nome ....então é isso, sempre possibilidades de nomes e acho que percebi que cada um deles tinha outro espaço.

O Aliosha, que é uma coisa que fica muito querida porque descobri quem era o personagem do Dostoiéviski muito depois e pela oposição porque meu pai era, se dizia ateu e justo, ele fazia questão de me chamar de Aliosha, que dos Irmãos Karamázovi é o irmão mais novo e que é religioso, é padre, então é isso!!

\section{De onde você veio até chegar ao Brasil?}


Nasci na Argentina, em Buenos Aires. É importante dizer em que mês se nasceu: 10 de dezembro de 1930.

É uma viagem que aconteceu de uma forma assim, vamos dizer, aqui no Brasil é fácil de qualificar: uma viagem mambembe, com bonecos. Eu fui viajando por vários países, fui viajar pela Argentina parando de cidade em cidade, coisa assim, norte e Argentina, fui para Bolívia, fui para o Peru, voltei a descer por esses países entrei no Brasil e cheguei em 61.

\section{Uma vez você disse que primeiro veio em $51 \ldots$}

Não, 55... Mas isso era outra coisa... Eu vim para um encontro de jovens pela liberdade... Se encontraram em São Paulo. Mas isso é outra coisa! Eu vim para o Brasil de uma forma mais decidida, até menos clara que um congresso.

Vim para tentar morar aqui fazer experiências, 61, entrando pelo Mato Grosso e chegando através da Central do Brasil no Rio de Janeiro, em 61. É isso? É isso, fazendo teatro de bonecos...

Chegando para me comunicar com uma escola de Arte, isso acho que é importante. Chegando para me comunicar com Augusto Rodrigues na Escolinha de Arte do Brasil.

\section{Você já conhecia?}

Eu conhecia pelo adido cultural na Bolívia, como sabia que eu estava indo para o Brasil, ele sugeriu, me deu uma carta para me encontrar com Augusto Rodrigues e a Escola de Arte do Brasil... 
Agora como eu falo nalgum poema, vou te passar esse poema porque acho que é interessante, está publicado agora em um livro discurso sobre o brinquedo, diz que saí com não sei o que, não sei o que e Herbert Read debaixo do braço.

O educação pela Arte, isso, com isso eu saí viajando pela América Latina, com isso eu cheguei ao Brasil e ainda com o Herbert Read debaixo do braço.

\section{E como foi sua infância... Você brincava de quê?}

Ah! Principalmente brincava de teatro, brincava de teatro, mas brincava também como as crianças brincam. As crianças brincam de teatro!! Porque aí fabulam, inventam, não sei que mais e passa a ser um teatro. Agora também brincava com características claras: Vamos fazer teatro!

Então, sentado o público em uma escada e ao pé da escada eu representava com várias outras crianças.

Representávamos o Príncipe Feliz de Oscar Wilde, eu não sabia que era Oscar Wilde, nem quem era Oscar Wilde...

Me contaram a história e me convidaram para assistir ao teatro aonde se fazia essa história, só que eu não consegui ir, era longe de onde eu morava que era uma periferia. Minha família estava sem dinheiro... estava sem dinheiro e era na cidade e ainda tinha que pagar os ingressos e não sei que e eu não fui.

Então contaram a história, e depois os amigos que foram eu perguntei como foi? E aí contaram como era o espetáculo. A partir daí eu comecei a fazer o 
Príncipe Feliz já que não fui eu fazia e fiz durante anos o Príncipe Feliz... Só depois na adolescência ou depois eu descobri quem era Oscar Wilde e que essa história que eu fazia era dele.

\section{Mas você costumava frequentar teatro, via teatro?}

Via, fazia teatro também, na escola, que não era uma escola, era... apenas era.... o Centro cultural de Imigrantes judeus poloneses, então, lá faziam atividades artísticas, sobretudo teatro faziam, então eu via o teatro que faziam lá.

Fora disso ainda eu via outros lugares, nessa época chegavam a Buenos Aires companhias do exterior, dos Estados Unidos, companhias judias que faziam teatro, operetas, peças de romances russos Dostoiévski, Tolstói, Gorki essas coisas, e também tinha, como era na época da Guerra, o fluxo da Europa tinha parado, então ficaram em Buenos Aires alguns grupos de atores que eram poloneses, que faziam periodicamente espetáculos. Íamos assistir. Vinham fazer recitais, abríamos a bilheteria...

\section{Você lá com a sua família?}

É claro! E fazíamos!! Tanto que o primeiro espetáculo que eu fiz... eu tenho a impressão, que se chamava Os espíritos, mas eu tenho a impressão que era de lbsen e eu fazia um pintor...

\section{Você era pequeno?}


É, com o cavalete, desenhava o espectro do espetáculo, sei lá o que... Era um teatro de adulto!! Também recitava poemas.

O teatro ocupou muito espaço mas também desenhava, pintavam fazia tudo que a criança faz..... construía cidades.... de barro, de pedras, e não sei que mais coisas que a criança faz...

\section{E você ia para a escola? Passava meio período, o dia inteiro?}

Aí é que está! Pela manhã eu ia numa escola do Estado, frequentava essa escola, também fazia alguma coisa de Arte.

Essa outra escola que eu falo era uma outra escola onde se estudava com base num língua que é um dialeto de alemão que os judeus da Europa Ocidental falavam...

Porque eles continuavam cultivando a língua que eles falavam, que se falava dentro de casa, eram imigrantes, então mandavam as crianças na escola para aprender a falar e escrever. Era época da guerra.

Então, uma vez eu falei que chamávamos a escola da manhã, a escola do Estado chamávamos spanichol, a escola em espanhol, e a outra era idichol, que falava a língua ídiche.

Já eu sei que tem alguma pergunta aí que cedo começou minha aventura com a repressão, com a polícia, e não sei que nessa escola chegou a polícia de repente e fecharam a escola, as crianças não podiam sair e confiscaram meu livro de leitura, que se escrevia papabueno...eles achavam que estavam ensinando comunismo coisa assim, papai mamãe, sei lá o que. 
É, um livro e acho que meu caderno também levaram para saber o conteúdo. E os pais, e só liberavam as crianças depois que os pais vinham e...

\section{Durante quanto tempo você estudou nessa escola?}

É o primário até 13, 14 anos. Jardim eu ia, mas não oficialmente, escolinhas que um professora que reunia crianças de todas as idades e dava aulas..

Você me contou que uma professora, em uma dessas escolas, tinha aprendido com o Javier de Villafañe a fazer bonecos...

Isso, no primeiro ano primário a professora nos ensinou a fazer bonecos e ela tinha tido aulas ou estava tendo aulas com o Javier de Villafañe e alguns discípulos dele, e ela me deu de presente um livro, um livro com três histórias dele muito conhecidas e que tinha uma epígrafe na primeira página que era: "Quando eu vejo títeres, quando eu vejo títeres quando eu vejo títeres..."

Ah! É... "passa como um fiozinho de ouro no meu coração."

\section{Você lembra até hoje?}

Lembro e tinha uma assinatura... é, agora dançou... "quando vejo títeres passa como um hilo de luz, coração". Ai caramba!!

Agora dançou ela vem... depois ela vem... 
Fulano, 13 anos. Essa frase era de um garoto de 13 anos, e ficou para sempre essa frase, já devo ter alguma vez falado dela... eu fiz uma música para um espetáculo que falava de uma coisa parecida.

Então, fazíamos bonecos e ela tinha sido, era aluna do Villafañe.

E essa infância, era num bairro muito característico, com muitas pessoas...

Bairro operário, de vários imigrantes. Indústrias predominante, era indústria têxtil.

\section{E seu pai fazia o que?}

Era operário têxtil, trabalhava em uma fábrica.

E sua mãe não trabalhava... Quer dizer, trabalhava em casa?

É. Trabalhava como uma louca.

\section{Tinha muitos filhos? Você tem irmãos?}

Éramos dois. Mas minha mãe cuidava de tudo em casa e além de tudo isso ela costurava roupa para fora, tudo isso...

\section{E a sua família veio toda? Seus avós, tios..}

Não! Porque eles começaram a fazer papéis para trazer a família, e aí estourou a guerra, está tudo nesse poema...

Falo o poema?

Sim... 


\section{Discurso sobre os brinquedos}

Hoje falaríamos de brinquedos,... eu preferia ser,... que fosse, nas escadarias do Olimpo,

nas pirâmides maias

ou qualquer rua em direção ao mar, mas não havendo maresiadas

nem Deuses, será apenas nos degraus do Serviço Social do Comércio... da Avenida Paulista

onde Midas mora, e eu não conheço,... nem quero conhecer!

Só conheci o mar, depois dos vinte anos, e os deuses invisíveis nunca, os meus Deuses são tangíveis, de fogo, mato, raio e trovoada. O grande brinquedo da minha vida, foi ser brasileiro, brincante e brinqueiro, eu sempre fui, com sol ou chuva sempre, nos quintais, $e$ às vezes nas escadarias do luar,...

Eu era pequeno! E não sou pequeno ainda?

$E$ às vezes tímido, estrangeiro e leve?

E outras diabolicamente ousado... dizem, pensam, calam de mim... perseguido com cores e palavras, da morte sempre a vida, o som e a voz cantando, no realejo encantado do dia a dia, choram também lágrimas salgadas.

Na mesa, a toalha do labirinto bordado familiar,

das ternas trevas onde corpos, suspiros e brinquedos não têm mais gravidade, recebia recados dos avós e do silêncio. Para lá partirei velho, eu sei, serei fantasma $e$ ancestral, o último suspiro embranquecido, pulando e brincando com a minha sombra marionete, no silêncio apenas cem anos, 
de flautas e tambores.

Renascerei depois com um choro imenso, renascerei rubro e criança, em qualquer olhar do tempo.

De criança neste século, nunca ganhei brinquedos no Natal em Buenos Aires, berço das minhas aventuras, nunca ganhei um brinquedo.

Ah! Sim, um elefante de borracha inflável de Varsóvia, ou qualquer cidade semelhante, de trincheiras bombardeadas.

Ganhei com a última carta, antes do pacto de Hitler e Stalim...

Renascerei tentando então, renascer em outra cidade no Oriente milenar, bordado a ouro numa feira no Peru, santo pequeno...

- Santurantiki... existirá ainda? ou numa casa torta de chocolate e tijolinho de Amsterdam, da avenida Singer... Frente ao canal.

Nos anos 40 desta vida, nas argentinas praias, nem sinos de ouro, nem guirlandas vermelho e neve de Santa Claus.

Era dia de Baltazar, de reis cristãos Seis de janeiro, eu não ganhava nada,

Eu não sabia porquê... Ou sabia?!

Mas aceitava, compactuava, fingia... pintando mais uma vez.

Passava anilina e cera num banquinho velho, que carregava como dádiva dos magos, nos sapatos da janela.

Meus olhos, uma flor envergonhada, amava sem brinquedos, de graça...

Sempre amei de graça

Minha mãe conspiradora e costureira Rosa Zacharias Dreher,

Rosa apaixonada, fada das agulhas e do dedal.

Os melhores remendos da minha vida...

Eu aprendi com ela, fazer a trama e a cama e remendar o coração...

Temia de graça, com adoração, meu pai autoritário: Jaime o tenor desafinado, 
ateu, asmático e tecelão.

Dele só sobrou um violino "roto"

o sonho e a utopia do futuro "rosso".

Brincar com quê? O menino "branco", anêmico, obediente, quase puro, quase...

que a falta de brinquedos,

brincava de teatro de figuras desenhadas,

nas janelas...

Brincava beijando ocultamente

nos cantinhos, no quintal do lixo

a menina meiga, Felisa Furman.

Também Helena mais alta e de olhos cinzas,

e Marta, uma primeira atriz

das minhas janelas,

que marejava lágrimas de outono,

olhos de safiras e príncipes felizes

de Oscar Wilde.

Do outro lado do muro, nos terraços inacabados,

(nada era acabado na periferia)

beijava e beliscava Pirula a galega, também seu irmão Pichin,

vesgo e órfão, desencontrando a ternura,

do medo e dos cata-ventos do remorso,

abraços, beijos, rolando e rodando, a liberdade pelo chão...

Deve ter sido castigo de Deus!

Deus não nos amava,

Isto, segundo as velhas armênias

e as gordas ucranianas, que em cima dos telhados

preparavam conservas e carne de sol...

eu nem sabia por que, não ganhava nada,

mas compactuava pintando mais uma vez...

O banquinho velho de tampo circular,

seria, pensava, porque meus pais eram ateus?

Ou porque, éramos também judeus?

A religião é o ópio do povo?

E ainda pobres poloneses da cabeça aos pés...

Pobres como pinóquio e Gepeto,

apenas uma maçã na mesa

e a sopa de lentilhas...

Um garoto pobre,

de casaco azul estreito e cachecol xadrez,

não pode nem deve estudar no Belas Artes,

é fantasia!'Disse aristocraticamente autoritária,

a diretora da escola Susana Tressaurieu, na sala Dom Pedro II, 
da Escola Brasil da periferia...

"É perder tempo!" Ela pensava.

Penso eu agora também... Talvez...

- Aprender um ofício,

técnica e artes, ofícios gráficos, ele precisa!

Brincando sem grandes sonhos impressionistas,

a profissão mais cubista, surreal, dadá...

pedras lisas e granuladas, medievais.

Eu escolhi mais uma vez compactuando

tramando como o meu pai,

remendando como minha mãe.

Litografias, magias alquímicas,

Alois Senefelder, descobridor e mago...

(depois de Gutemberg),

algum dia serão canonizados os dois...

Artes adolescentes gráficas

pelas ruas Montes de Oca e Martim Garcia, entre Barracas y la Boca todos os desejos ocultos, todos rodando e imprimindo, meus primeiros calos, amassei e toquei as tintas européias.

Pedras, zincos, tangos, swing, cantigas russas, litografia, off-set na sola do sapato, inverno no bonde, nas rotogravuras verão, escorreguei no asfalto e na goma arábica,

"Mambrú se fue a la guerra

Não sei se vai voltar"

Ácidos míticos, nítricos, sulfúricos, fosfóricos

e o mate, os papéis manila e outros que esqueci...

Esqueci Evita Mãe e as letras d'água.

O amor agasalhado na barriga, nas pernas e nos braços,

só a alma nua.

Flora sexagenária, também nua e infinita não cabia nas aulas de modelo vivo.

Isto depois de abandonar qualquer escola gráfica.

Na Sociedade Estímulo de Córdoba e Florida

me estilizava a percepção e o olhar...

Juntava ao carvão, as aquarelas, misturei tonalidades...

1 à impressão, o amarelo e a luz, a estrela de Davi e a foice

e o martelo,

$2^{a}$ impressão, avermelhado de bandeiras anarquistas

os frutos, romã que se chamava granada

3ํimpressão, azul sereno, ultra-mar, índigo, violetas das esquinas

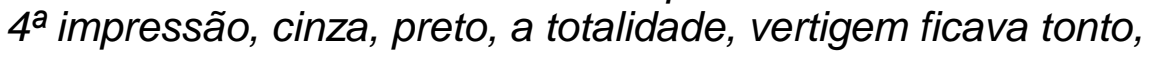




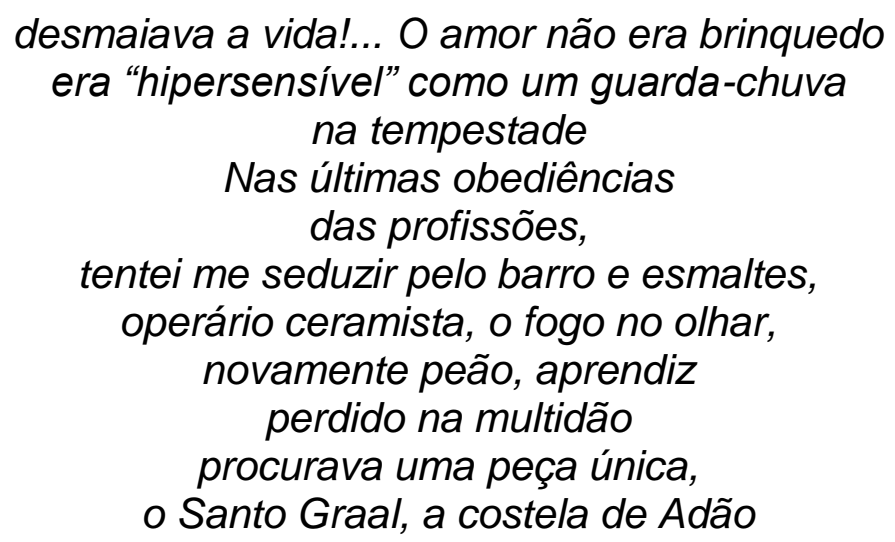

texturei o cobalto, o ferro, o cobre, Sartre e Simone de Beauvoir.

Ninguém comprava, morreu Stalin, morreu o Partido Comunista.

morreu Prokopief (chorei), morreu Jaime Pai, violinista aposentado.

Assinei e pichei os muros de madrugada, a favor e contra, fugi e me escondi,

à tarde neocubista, Gauguin, Van Gogh, Cezane, Loth,

à noite realismo socialista, Deus que nos perdoe!

Guerra, golpes, ditadura, liberdades, invasões,

a cadeira de brinquedo do inferno

de Etel e Julius Rosemberg.

Nem príncipe, nem cavaleiro, nem Dulcinéia.

Sentei no chão para brincar novamente, escolinha utópica do sétimo dia, sempre aos domingos, periferia.

"Mambrú se fue a la guerra, não sei se vai voltar".

Criança retorna e renasce com o dia, andarilho andante, amador de Teatro,

a pátria universal que ri e chora.

Enfiei o pé na estrada, Chê de olhos azuis, enfiei e dedilhei os títeres de pano, as figuras

desenhadas.

Papier marche, cabaças, garatujas,

com panos e lãs descabeladas, o alvo.

Neto e bisneto do velho Villafañe

Cavaleiro da mão de fogo.

E o jovem imortal, a la cinco de la tarde,

Federico Garcia.

Lorca no coração, Herbert Reed debaixo do braço, junto ao trilho do trem que partia para Bolívia. Rosa Z. D. perguntou...

Mas é só bonecos 
Que você vai fazer na vida ${ }^{4}$

Eu falo do Gutemberg, eu digo algum dia os dois terão que ser canonizados porque eles deram um grande salto na cultura...

\section{E o seu percurso de estudos, você se encontrou com o Javier de Villafañe...teve contato direto..}

Tive mas muito pouco, duas ou três vezes na minha vida. Uma vez fui num bar, com ele perto de um lugar aonde trabalhávamos, porque ele só bebia vinho, não é? Conversamos um pouco e depois em alguns festivais anos depois.

\section{A entrada para o teatro, como foi?}

Porque como estava fazendo desenho, cerâmicas, tudo isso, comecei a fazer teatro de bonecos com uma escultora, e depois desse teatro de bonecos, passei a fazer um teatro de bonecos na periferia, não é? $E$ depois disso começamos a andar por vários lugares e depois de repente disso participamos de algum festival.

E viajamos para a Bolívia, viajamos para o Norte do país voltamos, isso com 25 anos, e eu decidi que ia embora da Argentina e fui embora para a Bolívia. E aí começou Bolívia, Peru, depois Brasil e todo o percurso, a minha viagem fora da Argentina.

A minha migração é através de teatro de bonecos...

\section{E que você aprendeu diretamente com...}

\footnotetext{
${ }^{4}$ Publicado em BOTKAY, Caíque. Achados. Rio de Janeiro: Nova Fronteira, 2000.
} 
As pessoas que eram que trabalhavam com Villafâne, a professora. Isso quando éramos crianças, depois, quando éramos mais velhos, estávamos num grupo onde várias pessoas trabalhavam, tinha uma escultora que trabalhava com a gente e fazia bonecos.

\section{E a Mané Bernardo, di Mauro, bonequeiros.}

Eu não cheguei a trabalhar, conheci eles depois. Os irmãos di Mauro....

\section{São de outra geração...}

Não, di Mauro, quase, ele é mais velho do que eu um pouco....

\section{E a partir de quando se tornou professor de teatro?}

O professor está no poema... A escolinha do sétimo dia...

\section{0 que quer dizer?}

Que eu tinha um ateliê de cerâmica e nos domingos pela manhã eu abri, recebi alunos, sentávamos no chão, também fazíamos cerâmica, desenhava, não sei que mais e que eu chamo de escolinha do sétimo dia.

\section{Você dava aula de cerâmica?}

De desenho também...

Aí falta... No poema fala de pinturas que eu fazia que era Gauguin, neocubistas, um ateliê que eu frequentei, depois o ateliê do grupo comunista que era de alunos socialistas de Buenos Aires. 
Quando viajei com o teatro de bonecos pelo norte do Brasil, pelo norte da Argentina, Peru, tudo isso, parávamos em alguns lugares Aonde parávamos fazíamos um espetáculo e dávamos uma aula de bonecos para os professores e para as crianças. Dávamos aula.

\section{E você já conhecia o exemplo do Javier de recolher desenhos? Sim, conhecia.}

\section{Vocês recolhiam também?}

Sim, criou-se quase uma tradição de recolher desenhos. E o Javier, curiosamente, veio ao Brasil e ficou muito amigo do Augusto Rodrigues e o Augusto coloca ele como inspirador da experiência dele orientada para a criança. Quando ele diz, que viu um espetáculo do Javier, que o Javier falava... que os bonecos falavam a matemática:

Dois mais dois? São cinco!! Ele falava que a melhor aula de matemática que ele assistiu na vida dele.

\section{Então... Dessas experiências, qual você considera importante no seu percurso como professor de arte?}

Primeiro eu fiz assim, experiências junto com amigos, as escolas de artes gráficas me davam professores nada assim em especial que me marcaram, não é....Era gente legal, até teve um que era, chama Forte, é um pintor que depois vi no Brasi, lá na Escolinha de Arte, era assim um professor mesmo, mas nada assim de especial, o mais forte veio depois aqui no Brasil para mim a grande 
experiência foi entrar em contato com as populações mestiças indígenas da América Latina, ali eu aprendi coisas... Porque a cultura deles era muito instigante, eu vi eles fazendo artesanato, vi eles dançando, vi eles cantando.....

\section{Me lembro uma vez, você contou que uma menina fez um desenho na areia...}

Sim, isso no Peru, Peru perto do Cuzcu. Não, ela fez no papel, com um traço e colocou duas rodelas de papel, e a gente naquela época tomava cuidado, ainda, perguntar o que é isso ?

E ela disse: Isso é, com a professora do lado que traduzia, isso é....ÃÃÃ̃̃̃̃̃̃̃. Era o avião que passava, então, era uma experiência impossível porque é um critério de expressão que depois eu não vi em lugar nenhum. Em um escola aqui nós trabalhamos com a bidimensionalidade e nunca trabalhamos 0 espaço tridimensional com o desenho, não é? Nunca o desenho... agora, claro que 0 teatro pode ser 0 desenho que se movimenta mas o desenho gráfico mesmo não se movimenta, ela... era quase um brinquedo isso. Então é uma coisa muito forte, então, nesses lugares eu aprendi... muito.

Agora, depois vem aquilo a que centra as experiências que é o contato com Augusto Rodrigues e com a Nise da Silveira.

Que centra... Quer dizer, que organiza você já tinha essas experiências e...?

Sim, e amplia também, amplia o discurso, amplia o como se relacionar com o outro, cabe ainda perto deles algumas outras pessoas, que 
circulavam em volta deles que, por exemplo, agora importante, aparece muito é o Ferreira Gullar. Ah! Claro era da Escolinha de Arte do Brasil.

O Ferreira é uma pessoa que me influenciou muito na época quando eu cheguei no Brasil, me influenciou muito e teve outros, sobretudo, a Nise e o Augusto Rogrigues.

Ah, depois teve o Conservatório Brasileiro de Música com a é... como ela chama, a Cecília Conde, mas aquela que era professora dela...a ...começou toda uma pesquisa de música com crianças que.... Eu trabalhava com eles também dava aulas de tudo, aulas de criatividade, fazíamos teatro de bonecos, não sei que mais... Depois se criou o curso de musicoterapia, fazia parte desse curso da primeira etapa agora eles até se reuniram...

\section{O que era uma aula de criatividade?}

De criatividade... era sobretudo integrando linguagens que talvez 0 meu trabalho principal era criar espaços de integração, onde se trabalhava com várias linguagens simultâneas, porque até lá muito a Escolinha era teatro, artes plásticas sobretudo, gravura, música e horário de brincar, brinquedo, não sei que mais mas poucas vezes se fazia a integração e nós começamos a fazer a integração.

\section{Quanto tempo você ficou na Escolinha?}

Onze anos.

\section{E como era esse contato com a Nise da Silveira?}

Começou primeiro ela aparecendo lá na Escolinha, frequentando o mesmo, a casa dela, lugar onde ela estudava, criou um grupo de estudos, e o pessoal do Museu do Inconsciente... 


\section{E esse grupo de estudos...}

Hidi Minhone, se chama a criadora dos processos de música, professora da Cecília Conde, isso, a Hidi Minhone, do Conservatório Brasileiro de Música, iniciação musical, então são pessoas que marcaram muito.

Nessa época você dava muitas aulas mas não fazia espetáculos.....

Fazia, sempre fazia espetáculos de bonecos.

\section{Então era você e o Pedro?}

E o Pedro, e às vezes com outras pessoas que se aproximavam...

\section{É dessa época Ubu Rei com o Gianni Rato?}

Sim, ele nos chamou para fazer Ubu Rei, antes disso fizemos El Retábulo de Maese Pedro de Manuel de Falia, compositor que trabalhava com o Lorca, uma ópera, fizemos dois ou três dias na sala Cecília Meireles com a Orquestra Sinfônica do Municipal, depois saía muito caro e parou o projeto, com três cantores, a orquestra sinfônica dirigida pelo.... e a direção teatral do Gianni Rato, e nós fazíamos os bonecos.

E o que era importante propor para os alunos naquela época e agora? Que formação em Arte...

Acho que não mudou muito a situação, acho que... 
A primeira coisa, as manifestações mais essenciais da linguagem de cada um sem partir de conhecimentos, o auto conhecimento. Quer pintar, quer desenhar, quer fazer teatro? Qual o tema que quer desenvolver ? É a primeira.... Claro, depois experiências sensíveis com cores, com formas, com passo, com dança, com não sei que mais... Mas o ponto de partida é a autoexpressão. Isso é fundamental, o ponto de partida, começar pela libertação da auto-expressão libertar, abrir, para depois encaminhar conhecimentos, outras experiências e todas essas coisas...

E o que se tem do outro lado a partir do ponto inicial, o que seria a experiência mais elaborada.... Para além do ponto de partida...?

Eu não diria que é mais elaborada, é outro caminho... Um caminho talvez mais formal mais condicionado, mais condicionado, acho que é... Essa é a experiência do Augusto, da Nise da Silveira.

Mas também eu percebo de que faz faltas vivências. Então, nessas vivências são importantes que o aluno veja, tenha experiência de assistir, de participar de espetáculos, de ver de conhecer, de ler. Tudo isso é importante que ele tenha. Que não é apenas... Que facilmente se colocava ah! Não sei que, já sei, mas é jogar tinta na mesa, não é isso, como uma experiência fundamentada interior, não sei que, agora quanto mais a criança vê, quanto mais o adulto percebe o que os outros fazem, mais possibilidades de desdobramentos isso tem, não é que se copia, é outra coisa, vivência, experiência, integração de possibilidades, e você vai desdobrar, eu mesmo, me contaram a história do Príncipe Feliz de Oscar Wilde e então, durante anos foi o meu brinquedo, se não me tivessem contado possivelmente iria achar algum tema para desenvolver, mas a história do Oscar Wilde foi muito importante na minha vida, esse desdobramento, morte, ressurreição, não sei, todos esses temas que encara a experiência. 
Esses temas morte, vida e ressurreição e a busca pela liberdade estão presentes em quase, se não em todos os espetáculos nesses quase 28 anos de Ventoforte... É uma coerência, uma influência....

Liberdade, a procura da liberdade... Imagina... Aí já não sei, não, são muitas experiências. Mas eu sempre me digo: brincam de bandido, ladrão, mas é um ritual de ressurreição, porque ninguém quer morrer, te matei pá! Matei. Estão passando por isso no espetáculo...

...Aí a criança se recupera e está viva de novo, agora que percebi nesse último, você viu? Não, você não estava, a última cena agora no Portal das Maravilhas começa com um tiroteio, e aí eles estão marchando e eles caem todos mortos, os atores e os soldados saem, e aí daqui a pouco se levantam, todos viram todos como se diz, glamourosos, e começam a desfilar como se fosse um desfile de modas. Essa a ressurreição que eu coloquei nesse momento... as pessoas logo desfilam, já estão vivas de novo, eu fiz, brinquei com os atores, o rei ressuscitado.

Eu não diria que a procura da liberdade é muito querida, depois tem momentos que a própria poesia ela é o tema. Ela nascendo, se motivando, renascendo, é um tema eu acho também por cima da idéia, os conflitos, problemáticas, não sei que mais, a poesia nascendo por cima disso, é quase como se para dizer, como se retirasse a essencialidade. A poesia ajuda a encontrar a essencialidade.

E na formação de artistas e educadores o que você pretende? Como professor, quais os seus objetivos? 
Não é assim, eu digo, eu tenho uma vocação natural e aí que está meu autodidatismo que sempre que eu podia, eu inventava uma escolinha. Tão claro isso, eu já cheguei formado, não é? Formava um grupo de teatro de ao pé da escada que fazia teatro e não sei que mais, aí recebia alunos do bairro, crianças e trabalhava com elas. Aí viajava e na comunidade onde íamos fazer o espetáculo dávamos aula, aí ainda, agora no ano passado, a gente viaja e não faz por menos dá umas oficinas para os atores do lugar então a possibilidade de ir além, sem dúvida de ir além do espetáculo é muito grande das experiências pedagógicas, experimentar junto, descobrir conhecer melhor que as pessoas se conheçam, agora a verdade é que eu nunca estive num projeto, claro, assim de formação de nada, não é? Não, eu quero dizer, tem escolas de vários níveis aonde existem cursos que têm primeiro ano, segundo ano, terceiro ano, nunca trabalhei nisso, o único curso que fiz uma experiência assim de sequência é durante dois ou três anos, é no curso de musicoterapia, primeiro curso de musicoterapia, no Rio no conservatório de música junto com a Escolinha de Arte do Brasil e de uma escola que eu tinha também naquela época que se chamava Núcleo de Artes Criativas.

\section{Então, você tem a sua escola aqui, a escola do Ventoforte, da Casa do} Ventoforte...

Mas ela não é regular...

\section{Não é regular, mas acaba formando muita gente...}

Sim, como a comparação, já que sempre a gente tenta comparar é com o estilo quase medieval, das oficinas de arte, aonde o aluno ele aprendia com mestres, o mestre trabalhando com os alunos, passando os conhecimentos, experiências... 
Foi assim que você pensou o curso do Ventoforte? Como foi que chegou a ser...

Não, não exatamente, a realidade não permite nunca chegar a uma escola mais planejada, sem dúvida que é esse o projeto, que está vivo, que ainda mas possivelmente a formação deveria ser um processo talvez mais elaborado.

Então você acha que essa escola ainda está incompleta...

Não, não é isso. Nós somos isso. Capaz que vamos ser sempre isso porque nunca houve uma proposta clara...

Mas que ela forma gente, forma!! Sem dúvida, tem gente que formou aqui.

Como conduz o caminho dos seus alunos? Quais são as etapas pelas quais passa um aluno formado pelo llo?

Não sei, talvez tenha que se repensar cultura e uma série de coisas, informação. Talvez...

Então nós tivemos, você até participou de reuniões em que às vezes se discutia até alunos, não é verdade?

Então talvez deveria ser uma coisa mais, mais orgânica, com mais tempo para ser visto isso, o processo dos alunos, as possibilidades de cada um, dentro do limite.

A escola, a gente pensa, sim, sempre pensa, porque parte disso, a expressão individual então está partindo desse indivíduo que a gente já sabe como se chama, acaba sabendo pelo mapa da vida tudo o que o indivíduo fez desde que nasceu até o momento que está fazendo o curso, tem uma série de experiências. 
Mas eu acho que poderia ser mais... Deve ter uma queixa no que estou dizendo, que poderia ter um sentido mais pleno, mais... A gente luta para que exista 0 processo. A realidade nos retira o processo e nos impõe apenas experiências mais eventuais, isso a realidade é assim, mas deve ser assim mesmo nas outras escolas também eu acho; que não há espaço muito bom, espaçoso, muito rico para aprofundar, sempre nos falta um pouco.

\section{E na idéia medieval, do mestre com seus alunos...}

Mas não sei se é tão organizado a oficina medieval, o ateliê medieval. São contingências de vida, então você não pode dizer olha, no próximo ano, para mim é difícil, no próximo ano você terá que fazer isso ou aquilo e eu não sei se no próximo ano a pessoa vai estar aqui.

\section{Existem relações entre o llo professor e o diretor?}

Sem dúvida, porque tudo é pesquisa. Estou trabalhando sobre processos que eu conheço, mas que eu não perco tempo de tentar sempre ampliar estes processos, Ainda que seja com alunos inexperientes, sempre estou tentando avançar num processo.

E em lugar de me diluir, de manhã faço não sei que, à tarde não sei que e de noite sei lá o que, tento que tudo crie um tecido para mim, para desenvolver a minha experiência teatral estética teatral também.

Pesa, sem dúvida eu me coloco mesmo assim para receber influências do próprio trabalho que acontece com o aluno. 


\section{Por que chama as crianças para participarem dos espetáculos?}

São vivências, uma experiência de comunicação... Aí é que está.

É dar muita importância a criança brincar, ao ser humano brincando, fabulando, inventando, sem dúvida o que deixa um rastro de vivência muito positivo para ela poder sempre brincando descobrir.

Brincando para mim, é que rejeito a palavra faz de conta, não é o faz de conta, fazendo vivência mesmo, não é?

Fazendo vivências... Não é a toa, nem automaticamente, nem conduzindo, nem manipulando, viramos para a direita, viramos para a esquerda e não sei que mais é dar espaço para a afetividade na comunicação.

Em Lenços e Ventos, na Suíça, as crianças davam para construir o papel que ia entrar no Castelo Medieval, mas só com metal poderiam entrar, então eles davam relógios, chaves até alguém falou baixinho é o símbolo da Suíça: relógios e chaves, que eles trabalham com capitais e com relógios, mas para toda a classe média, classe média alta, o relógio e as chaves são o poder...

Faz parte da... eu deixo correr uma idéia de brincar, de comunicar-se.

As boas intenções não são uma formulação nem ética, nem moral, as boas intenções são uma proposta, a partir daí, se você entrar na metáfora do brinquedo, você vai ter uma proposta ética de comunicação com as pessoas, entendeu? 


\section{Como os anos de repressão política e ideológica se refletiram nas suas}

experiências de vida e no seu trabalho?

O tipo de teatro que nós fazíamos era pouco atingido por isso como, como pessoas sérias e conscientes do que estava acontecendo em volta não, como a repressão as idéias, a gente lia, até os livros tem que esconder em algumas épocas, livros, então, e tudo isso fazia parte desse universo, mas a primeira manifestação, $A$ História do Barquinho é um canto à liberdade e foi criado um pouco antes de 64, fazíamos com os alunos, então é a liberdade, querer ser livre e passar por tempestades e voltar a renascer e ficar junto com quem se ama, soltar as amarras, mas em 73 fazemos isso no Chile e aí as pessoas que estavam vivendo um momento muito político olhavam com um olhar político para isso. Como era importante ter um protagonista que não queria estar preso, queria se libertar. É o público me devolveu, me espelhou, que estava fazendo já fazia anos, porque era um público, era um...não, eu sabia era a como se diz, enquanto eu estava a unidade popular então era o momento que se vivia essa coisa, ser livre, morrer, sair de todas essas ditaduras militares e não sei que mais. Então isso estava presente...

\section{E em Lenços e Ventos...}

Claro, aí não ia falar o acidente brutal que foi o golpe do Chile, então quando volto para o Rio monto Histórias de Lenços e Ventos.

História de Lenços e Ventos tem por trás uma grande dor, dor e enquanto tudo que tinha acontecido, quanto tudo que tínhamos perdido gente que tinha trabalhado com a gente que tinha sido assassinado lá no Chile, tudo isso então é consciente, falar do poder repressivo, tudo isso aparece em Lenços e Ventos.

\section{E por que para crianças?}


Porque era com a criança, fazíamos nesse momento teatro para crianças, então fizemos, depois disso fizemos Da metade do caminho ao país do último círculo, já tinha sido escrito antes, que já tinha temáticas, tinha o país da guerra, o país do sim o país do não, quem governava o país do sim... Isso foi escrito em 70 mais ou menos 71, quando estava fazendo o Barquinho no Rio de Janeiro já estava escrevendo essas temáticas Da metade do caminho ao país do último círculo, como conto depois feito a peça. Porque o gigante azul chora, sempre tema da guerra da repressão.

O país do sim e do não eram países terríveis, onde você podia ou dizer sim em um tinha que dizer sim a tudo e no outro tinha que dizer não a tudo, que no fundo é a mesma coisa e que no fundo é governado pelas mesmas pessoas e um dos protagonistas que morrem na guerra, e enfim, tudo isso já tinha um fundo político, mas quando fazemos Lenços e Ventos foi consciente, já sabemos o que estamos falando e colocamos num palco painéis forrados de jornais onde homenageamos todas as pessoas que a gente conheceu que lutavam por liberdade que foram importantes, que conheci na Bolívia, que eram sindicalistas, o dia que tinha sido preso, um sindicalista que muitos anos atrás eu tinha conhecido na Bolívia, na cidade de São Luiz do Potosí, isso quando viajava com Pedro, eu conheci ele lá, eu li nos jornais que esse sindicalista tinha sido preso, botei o nome dele lá. O nome do menino assassinado em Santiago do Chile, o Luís.

Então ele é colocado sempre, alguns amigos que vinha ver o espetáculo a gente colocava os nomes, homenageava, já tinha todo um fundo político sem dúvida, proposital, e por isso sabíamos que num momento da morte do herói, do jornal, do jornal de papel que ia ser queimado frente ao censor, discutimos vamos fazer essa cena, ou não fazemos, aí o censor dormiu e ele nem percebeu, a primeira, porque teve várias, a censura sempre assistiu, nunca tivemos problemas, eles ficavam desconfiados, o último que assistiu no Rio, não aqui em São Paulo, 
ele ficou... Disse tudo bem... Vamos liberar, saiu andando pelo teatro e se voltou, ficou vermelho, mas este texto tem alguma coisa sinalizando, assim apontando com o dedo, mas ele não foi proibido.

Mas fomos mais molestados pelas histórias do Lorca e um dos últimos Sete-corações a censura implicou, não queria liberar para crianças porque o poeta é assassinado, e aí eu argumentava e falava e se fosse a história de Tiradentes, como apresentaríamos a história de Tiradentes, não é? Enforcado, não é isso? Não seria enforcado? Só que nós não usávamos fuzis, com as vassouras como crianças brincando, simulamos as armas, não é? Sim, a partir de Lenços e Ventos vai se instalando, claramente como um projeto político fazer teatro, também, mas não é um projeto político, se instala uma coisa assim, poesia, ela sempre fala de coisas da vida, da repressão, da liberdade, se deixar de falar, de falar disso acho que ela nem existe...

\section{Como é seu processo de criação junto ao Ventoforte?}

Se trabalha muito em cima de improvisações, essas improvisações são temáticas, muitas vezes os temas têm a ver com o que está se desenvolvendo, às vezes com mais detalhes, às vezes mais em generalidade, agora trabalhamos a igualdade, a marginalidade, a pobreza, a miséria, são generalidades mas depois entramos a trabalhar a mendicância, as perseguições, depois centrar as informações sobre o próprio tema.

E aí também eles trabalham comigo, tem uma música que se canta desde o começo, que é a fala de um personagem muito perseguido, que é o Jean: quando está morrendo que ele diz: morrer é quase nada morrer é não viver assim, assim, e daí eu crio uma música que eles cantam e não sei que e vai e vai e vai indo em cima disso, então se bate num tema e se vai desenvolvendo, isso se 
transforma em tema de uma cena de um saguão de sangue que viveram mal, horrível é não viver, horrível é viver mal, não é morrer não, é o mais, não é nada morrer, mas não ter vivido é grave, essas coisas são parte do tema, como tem outros também. Então, se começa muito com improvisações por informações.

Tem vezes que trabalhamos com textos prontos e outras vezes que vai sendo criado o texto, eu crio o texto. Muitas vezes eu crio o texto um pouco pensando no ator que vai fazer depois, se tiver que substituir em algum momento pode até se substituir, mas a primeira fase nesse trabalho, por exemplo, agora, é como se eu estivesse escrevendo para o ator, sinto isso, é para a imagem dele. Então e aí são os espelhos, as identificações do próprio ator com os temas e aí que vai acontecendo o processo, agora como chegar a sínteses, como chegar a coisas essenciais, não ser realista, naturalista. As sínteses poéticas que às vezes não estão nem nas palavras e nem nos gestos, alguma coisa dessas.

Algumas situações, outras não, o texto é criado junto, e a música tem sempre um compositor, é coletivo de muitas formas, porque eu estou dirigindo e são todos textos, há alguma pessoa que dirige musicalmente, começa a compor cenas, a música para algumas cenas e às vezes é algum estímulo dos atores, e a gente integra, então, são coisas que acontecem desse jeito. Os atores ainda estão lendo a obra do Vítor Hugo...

Mas às vezes aparecem temas, coloquei o tema da Anita Garibaldi que aparentemente não tinha nada a ver com Vítor Hugo, mas tem a ver pelo século por que ela foi a paixão do Giuseppe Garibaldi, que por sua vez foi um lutador que... criar repúblicas na Europa e era muito amigo do Vítor Hugo, Vítor Hugo, por ser amigo dele que era perseguido, teve que se exilar se exilou em uma ilha não sei por quantos anos, da França, da Bélgica. 


\section{Qual é a sua compreensão de criança? Que criança é essa? Para quem se destinam os espetáculos?}

A gente encara a criança, eu digo encara por que bota a cara prá ela. Isso é fazer teatro, então a gente sempre acha que a criança tem mais liberdade para brincar para se envolver no lúdico do trabalho, então a gente já está com o olhar que se comunique, uma proximidade maior do que com o adulto.

O adulto às vezes tem resistências, tem... sei lá, até comportamentos não se entrega facilmente... Ao olhar nós fazemos um trabalho de corpo a corpo de aproximação, de olhar que não é muito comum em teatro, então, esse olhar é quase tocado, ficar de olho, dar texto de olho em alguém, isso é uma improvisação, importante em alguém, em alguns...

Já com as crianças isso é menos problematizado, se ela tem vontade ela brinca, ela percebe que estamos brincando, percebe até que está se improvisando uma história, não acredita assim como uma realidade absoluta, ela sabe o que está se fazendo e a partir daí ela fica cúmplice. Agora, é cúmplice, mas de repente pode se envolver tanto que pode rir ou chorar pelo que está acontecendo, bate a emoção nela, mas é tem um momento que ela se transforma em cúmplice, que ela vê que somos brincantes.

Brincantes, é isso que provoca a intimidade com ela, e aí, quando já vamos avançando para o que chamaríamos a participação, ela participa às vezes ela mesmo pensa ou descobre alguma coisa sobre o espetáculo e vem nos comunica: olha, por que não fazem isso ou aquilo, começa a tomar uma intimidade com os atores.

Não é assim, olha, é um ator, não, assim são pessoas que brincam igual que ela, como ela, com ela. 


\section{Como gostaria que seu trabalho fosse visto?}

Aaaaaah não! Essa é a pergunta, ela é importante?

Ah! Visto? Importante é abrir o coração, a sensibilidade, não, a gente quer que as pessoas venham ver, não é só ser visto, é abrir os olhos, abrir o coração, é abrir a sensibilidade, se prestar a esse jogo que estamos propondo, para nos seria e é geralmente e acontece, e quando acontece nós sentimos assim bastante, assim justificados, até .

A gente adora fazer teatro, não é? E sem isso é meio difícil de se fazer, não é ? Já quem está fazendo é por que adora fazer teatro... Que sem isso é meio difícil de se fazer, então, quando se coloca em frente ao público, o público sente também, quando os atores estão interessados no que estão fazendo, estão vivenciando uma forma intensa afetiva, isso já comove ao público, intriga para os que pouco viram teatro, que que eles estão fazendo, o que que eles vão querer fazer com a gente...nos chega este também, teatro tudo previsto, o público pode pensar: já sei o que vai acontecer...não tem que se enxergar o que vai acontecer, tem que ser uma caixa de surpresas contínua, sobretudo ainda para crianças porque... a gente procura surpreender, esse jogo é muito importante.

A palavra espelho é superimportante, porque ela... a palavra que coloca assim agora a surpresa, o surpreender o público, e o público nos surpreende porque o imaginário é meio imprevisto e inesgotável, a gente ser surpreendido pelo olhar da criança é muito importante.

\section{Qual é a sua contribuição para o teatro, o ensino de Arte?}


Ah... Eu acho que a contribuição do artista, do didata ou a pessoa que realiza sempre se ela, o alvo é contribuir, até quando você trabalha com pequenos alunos, crianças, não é formativo, de contribuição, e ele troca, é de troca sempre, é de troca e não é um caminho que vai da gente para eles, é um caminho com retorno, vai retornar de alguma forma, não é? Isso é que tem de lindo, se espelha, o espelho é perfeito, se espelha, devolve. A gente se espelha no público, o público se espelha no que nós fazemos, então isso vai repassando, as imagens as vivências, não é....?

Existe uma cadeia de transmissão do Lorca para o Javier e para o llo, é uma cadeia de transmissão? Que cadeia é essa?

\begin{abstract}
Ah... Parece uma coisa assim... Muito... É... Hoje que também, talvez eu esteja assim diferente, com uma certa humildade. Mas tudo bem pode ser, é que deve ter muitas, deve ter outras cadeias de transmissão do Lorca para muitas pessoas, mas eu aceito, muito sensibilizado e honrado essa cadeia de transmissão do Lorca para o Javier, o Javier para uma professora que se chamava Helena e que me ensinou a fazer bonecos e que me deu o primeiro livrinho do..., é uma cadeia que se estabelece até maior, não é ...?
\end{abstract}

Então, mas eu aceito, graças a Deus como quem diz o que não aceito é o Lorca logo ter sido fuzilado, assassinado. Lamentamos até ele não ter ficado em Buenos Aires, em lugar de voltar para a Espanha para ser de novo perseguido, destruído.

Então, o... Mas é real, acontece de certa forma. Eu era criança, já o Javier fazia parte da minha vida através da professora que se chamava Helena, eu não guardo bem nomes, ela chamava... Veio agora em mente Verrilho, que, aliás, 
eram duas irmãs e as duas tinham ido estudar teatro de bonecos com Javier e com alguns discípulos do Lorca: Helena e Josefina Verrilho.

\section{E o Lorca, você entrou em contato com as obras dele mais diretamente? Vendo espetáculos, lendo...}

Eu me interessei claro, eu vi, eu li, vi uma atriz que trabalhava com ele fazendo $A$ Sapateira Prodigiosa que é uma mulher de 70 anos que fazia o papel de uma moça de 18 anos e A Sapateira Prodigiosa eles chamam de comédia...., comédia? comédia? não sei que violenta, farsa violenta, comédia violenta, uma coisa assim meio colorida, desenfreada, então eu vi feito por ela. Eu vi também a uma das primeiras atrizes dele que é a Lola Membrives

Eu vi ela acho que em filme, foi, gravações, porque eu não me lembro se eu vi alguma vez de pequeno, ver ela, mas eu sei que a imagem dela está presente fazendo Bodas de Sangue.

Devo ter escutado também gravações da peça, a que fazia Sapateira Prodigiosa se chamava Margarida Xirgo e ela se exilou no Uruguai, tanto que no Uruguai tem uma escola de teatro que ela criou, é uma escola oficial já faz muitos anos, mas foi ela que criou uma escola de teatro de Montevidéu, ficou o nome dela, Margarida Xirgo. Então, ela e a Lola Membrives que era a outra praticamente eram duas entidades femininas que realizavam os espetáculos dele, do Lorca.

Eu me lembro que fui em algum, sim...teve uma época em Buenos Aires que se cultivavam recitais com poemas em teatros, fazíamos recitais com poemas de Garcia Lorca. Eu vi isso alguma vez, então isso foi se integrando, não é? As pessoas que cantavam Lorca no rádio ainda, as informações foram se somando, não é uma coisa assim tão definida mas aconteceu sem dúvida, aconteceu 
quando já passei da adolescência, depois dos 20 anos eu já sabia já bastante quem era Lorca e ele era cultuado em Buenos Aires, sem dúvida que era cultuado.

E ao mesmo tempo também minha família, vizinhança, que eram muitos espanhóis que moravam perto de onde eu morava, a experiência da guerra civil espanhola ela foi muito forte, então isso estava dentro do mundo dos adultos, mas a criança recebe tudo isso, todas essas informações, do franquismo, do fascismo que estava se instalando na Europa, dos voluntários que iam a lutar pela república, que cantavam as canções que o próprio Lorca resgatou, popular, mas mudando até letras.

E depois de muitos anos,... eu aprendi a cantar uma música que até ...que...depois de muitos anos cantei no espetáculo com outra letra, com a letra que o Lorca levantou, mas quando eu aprendi era o quinto, quinto, então era o quinto regimiento...

Com o quinto, quinto, quinto com el quinto regimiento el partido comunista deféndiendo está Madri! Isso cantavam os voluntários que foram a Espanha e voltaram para Buenos Aires depois de muitos anos eu cantei Com el vito, vito vito com el vito que me muero cada dia nino mio estoy más metida en fuego. Esse o texto popular recolhido pelo Lorca, então essas coisas, essa movimentação da temática da guerra civil, ele se transformou em uma das primeiras vítimas do pensamento fascista.

Não é casualmente, não foi assim sem querer, como faziam parecer, capaz que ele dançou... Como se fala assim sem querer, não, ele se afastou de Madri, foi se proteger na cidade dele, inclusive foi morar em casa de uns amigos que eram praticamente franquistas, eram mais da direita, mas arrancaram ele de 
lá e levaram e de madrugada fuzilaram e essas outras..., outras teorias torpes de tudo que fizeram com ele etc, etc.

Pagou o preço dos preconceitos, ele era um líder libertário, era popular. Sexualmente fazia o que queria da vida dele, tudo isso incomodava muito a burguesia, a direita, e aí o texto dele:... Nós somos do teatro... E não sei que... $\mathrm{E}$ nós estamos rindo daquele teatro dos lustres dourados... Não sei que mais... Mas estamos... é... Muito lindo o prólogo dele para muitos textos em que diz que vem renovar que esse ar que ficou daquele teatro da burguesia, nos anos 30, estava empesteado estava poluído pela fumaça dos cigarros não sei que mais... Agora poderia se traduzir isso quase como uma postura ecológica, mas era ecológica de, o verdadeiro sentido do teatro. Tudo isso foi se instalando, informações... é...

Acho que o que inspira muito, também tem um poema dele que na minha adolescência me apaixonou muito, que é o poeta em Nova lorque, que era já a etapa, etapa final até morrer, que é uma etapa mais surrealista, que falava de problemas políticos, o que ele sentiu frente à grande cidade, ele ficou fascinado, mas ao mesmo tempo deu aquela turbulência de que se misturava nessa grande cidade.

\section{Qual o primeiro texto do Lorca que você montou?}

Me dá a sensação que alguma...devo ter brincado em aulas, com os alunos, e antes disso devo ter brincado talvez com aqueles... Amor de Don Pirlimpim e Belisa no seu jardim, tenho a impressão que são pecados assim bem juvenis. Se reúnem, fazem em uma festa fazem...uma coisa assim.

\section{Então o primeiro foi As Pequenas histórias de Lorca?}


Claramente é...

\section{E existia um texto do Lorca que você quisesse montar...}

Não, porque acontece o seguinte: até 70 , até os anos 70 ainda era o remanescente de um andarilho que andava fazendo teatro de bonecos pela América Latina, era o remanescente, já estava instalado no Rio de Janeiro, mas

tinha essas características, eu não fazia teatro assim para ser apresentado em temporadas, eu fazia teatro de bonecos, teatro com as crianças, não sei que, mas não fazia temporadas, nos anos 70 aí já não me lembro, fizemos a ópera do Manuel de Falia, com Gianni Rato.

Então foi a primeira vez que eu trabalhei, mas trabalhamos três dias em uma sala de concertos, a sala Cecília Meirelles, até essa época de antes éramos, nós conhecíamos os andarilhos que faziam de cidade em cidade, de bairro em bairro, de escola em escola, de país em país, ou lá no Rio, mas também sempre de uma forma assim, nunca esse teatro que acontece oficialmente em salas estáveis, essas coisas eu não fazia.

Então, a verdade, a primeira montagem teatral minha que vai para um palco e fica num teatro e que fica em temporada é $A$ história do Barquinho, nos anos 70 e... 72. E em 73 faço isso no Chile e em 74 faço Histórias de Lenços e Ventos que ai para já a teatralidade minha assim em palco, no palco, e o palco inclusive usando livremente, claro já tinha feito isso.

Praticamente vivenciar o teatro do dia a dia, feito na escola, em uma feira em qualquer lugar... 
Em A História do Barquinho, encontro uma maneira poética de llo Krugli definir-se:

\author{
"Eu sou um rio, \\ que nasce novo, \\ que morre novo, \\ que nasce louco \\ e sonha trêmulo, \\ vira cometa de longa cauda na terra aberta \\ com fogo e água dos caminhantes \\ dos andarilhos \\ na selva. \\ Eu sou menino navegador \\ Do rio novo que desenhei no mapa antigo do coração, \\ Coração do menino navegador." 5
}

E sendo um rio, llo tem, então, afluentes, deltas, margens e meandros. Começamos falando do divisor de águas, a nossa próxima tarefa é organizar os rios e suas confluências.

${ }^{5}$ Letra de Ilo Krugli e música de Ronaldo Motta. 


\title{
Capítulo II Que enfrentou quatro portas...
}

\begin{abstract}
"Um texto que começa com Era uma vez... envia um sinal que Ihe permite de imediato selecionar seu próprio leitor-modelo o qual deve ser uma criança ou pelo menos uma pessoa disposta a aceitar algo que extrapola o sensato e o razoável"
\end{abstract}

Umberto Eco 


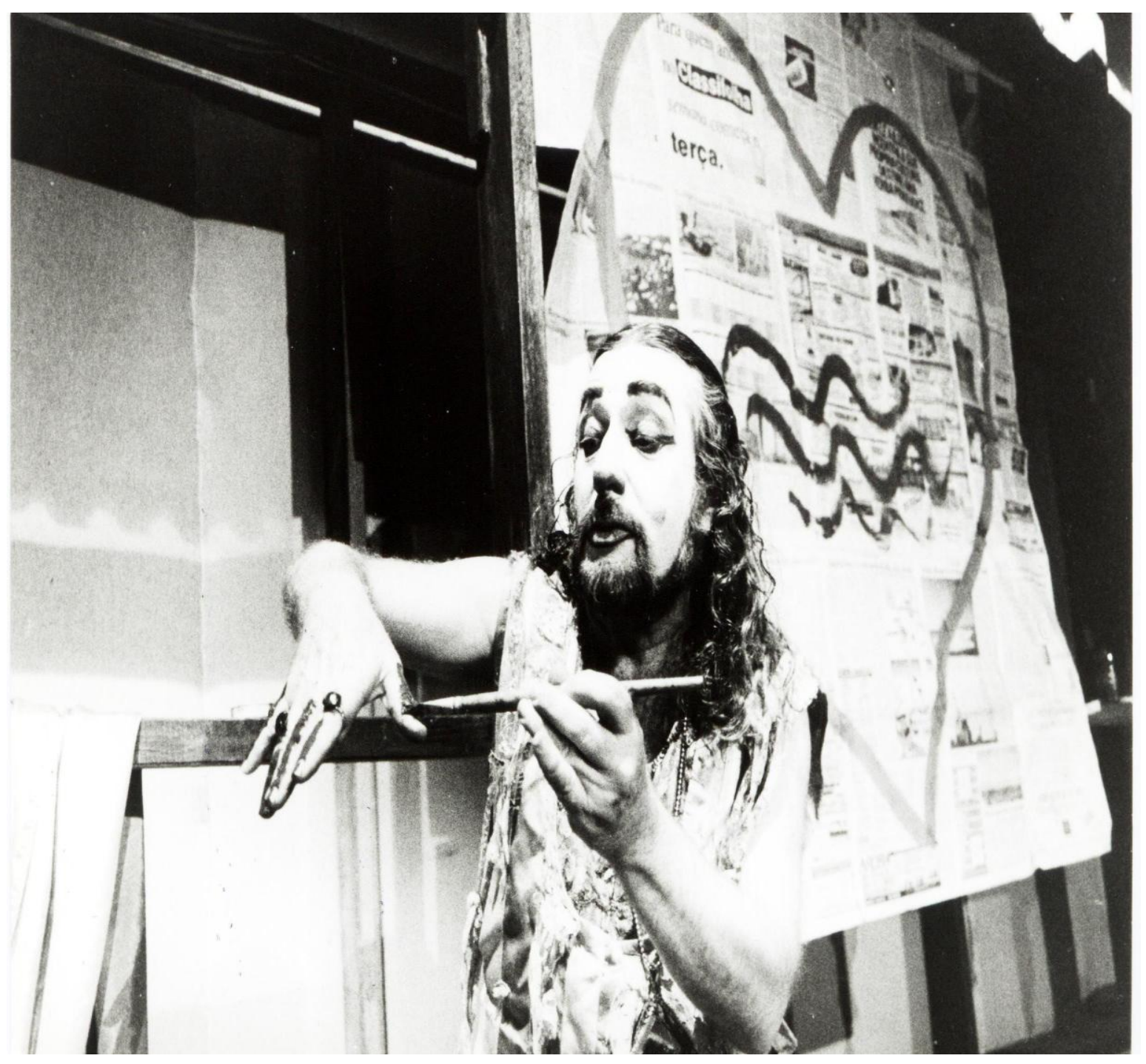

Ilo Krugli. O rio que vem de longe. Foto Gil Grossi. Arquivo Ventoforte 
Era uma vez um menino loiro de olhos azuis bem claros, límpidos como o arroyo límpido da cantiga de ninar espanhola...Claros como um rio.

A la nana, nana, nana, a la nanita de aquel que llevó el caballo al agua y lo dejó sin beber...6

Que brincava de ser ator no vão de uma escada, aos oito anos, em 1938, em um sobrado no bairro de imigrantes judeus poloneses na cidade de Buenos Aires, capital da Argentina. Lá brincava de ser ator o menino Elias, seu texto era O Príncipe Feliz, de Oscar Wilde.

Imaginar llo criança, brincando, não é difícil, já que em muitos espetáculos podemos ver llo Krugli assim. No Portal das Maravilhas, na cena do teatro de bonecos de papelão, é como se pudéssemos vê-lo nas ruas de seu bairro misturado às outras crianças, ouvindo histórias e assistindo às apresentações, as figuras de papelão. Nesse espetáculo ele é o dono destas figuras e há o medo do inquisidor. Seu personagem é mestre do teatro, dono das figuras, dos bonecos de papelão e é acusado de usar símbolos judaicos.

- Confessa que você é judeu! Grita o inquisidor. E Ilo Krugli/Mestre Serrão confessa que é artista e que usar símbolos é parte de seu trabalho.

Quando seu personagem é, enfim, preso pela Inquisição, o ator/diretor em seu texto relata ao público as maravilhas, dissabores e percursos de quem vive desde sempre para o teatro. A interpretação da personagem por Krugli é realizada ao modo de representar que convém à proposta cênica do seu teatro: olhos nos olhos e com muita emoção. E parece-nos relatar ali sua própria história.

6 LORCA, F. Garcia. Conferências. Brasília: Editora Universidade de Brasília: São Paulo: Imprensa Oficial do Estado, 2000. 
Subia no telhado para olhar as estrelas e tem essa mania de olhar para o céu. O pai, artesão e ateu, dizia que Deus está ali: e mostra as suas mãos. Como são expressivas as mãos de llo Krugli... o menino llo, ao ouvir o pai, subia no telhado, olhava as estrelas e pensava em Deus. Às vezes se escondia embaixo da cama com medo que o viessem buscar, tinha roubado terra, encheu uma lata com ela em um terreno e não sabia que a terra tivesse dono.

Aprendeu a fazer bonecos na escola, com uma professora que teve aula com Javier de Villafâne. Eu ainda posso vê-lo em minha memória no Mistério das Nove Luas, levando o Mané, boneco que ele manipula a história inteira; é um trapinho com olhos, mas nas mãos dele é gente! Dizendo carinhosamente que ia levar o Mané para a creche. No Mistério, llo/Mané brinca.

Brinca sempre de muitas maneiras, aproximando-se das crianças da platéia, e de todas as participações espontâneas deflagradas pelo caráter lúdico e de jogo que pude ver. A mais linda acontece no Mistério. Ele diz que para salvar a onça, que tinha sido levada da floresta, é preciso mais do que dinheiro. Instantaneamente, os atores saltam para a platéia pedindo mais do que dinheiro e as crianças entregam o que têm à mão: sacos de pipoca, chupetas, sapatinhos, o bichinho preferido, celular do pai, bolsa da mãe.... generosas, solidárias, afetivas, de olhos brilhando. Tudo é recolhido em um grande saco; os atores agradecem muito e levam para trocar pela onça.

O teatro de bonecos que aprendeu em criança e o livro que leu no primário (do poeta e bonequeiro argentino Javier de Villafãne) marcaram a vida e a obra de llo Krugli; mais apropriado será dizer que definiram o curso do rio, foram catalisadores da experiência sensível que pode ser a infância. 
Javier de Villafãne é uma figura tão importante que por si só mereceria uma dissertação inteira. Muitas das informações coletadas sobre ele vieram oralmente através de bonequeiros argentinos e brasileiros. Há muito ainda a ser feito pelos registros históricos que ligam a história do teatro de bonecos itinerante e a história da Arte Educação no Brasil e na Argentina.

Querido, pesquisado e editado em seu país de origem, Villafañe circulou com seu teatro itinerante de bonecos pela América Latina e pelo Brasil. No Rio de Janeiro, teve significativa importância nas reflexões de Augusto Rodrigues e na fundamentação do Movimento das Escolinhas de Arte. No sul do Brasil, graças às andanças de Javier, existe ainda em Canela e em outras cidades a tradição do teatro de bonecos onde Villafañe é cultuado. No Nordeste, entrou em contato com Ulisses Pernambucano, médico-psiquiatra e educador, que juntamente com Noêmia Varella e Augusto Rodrigues fundaram, em 1953, a Escolinha de Arte do Recife.

Javier de Villafañe nasceu em 1909 em Buenos Aires, e na infância assistia as apresentações de teatro de bonecos que representavam Andersem, Grimm e Perrault, e ainda a história de Fausto e Margarida, de Goethe, dirigidas por Dante S. Verzura, no Jardim Zoológico de Buenos Aires. Conheceu com um casal de sicilianos as marionetes que o impressionaram muito. Em contrapartida, na escola, vivenciava o embrutecimento e a incompreensão dos professores. Nos recreios, sozinho, costumava olhar para o céu apreciando o vôo dos pássaros e alimentando-os, sendo por isso alvo de repreensões e chacotas.

Em casa, porém a mãe lhe contava a llíada e a Odisséia, histórias das quais se lembraria sempre; a literatura oral nos seus primeiros anos de vida, antes 
de entrar na escola primária, Javier afirma ter sido determinante na sua vocação futura. ${ }^{7}$

Seguiu-se à escola o serviço militar obrigatório e lá Javier descobriu que poucos de seus companheiros sabiam ler; pediu então permissão para ensinar os companheiros a ler e instalou a leitura no quartel. Soldado-bibliotecário, Javier escreve e lê para seus companheiros seu primeiro texto que conta a história de um cavalo, um capitão e um sargento. A primeira do que seria uma vasta obra para crianças que ainda está sem tradução no Brasil.

O poeta espanhol Federico Garcia Lorca, que se identificava com os mouros, os ciganos e os andarilhos, visitou a Argentina com a companhia de Lola Membrives para a estréia de Bodas de Sangue, durante os últimos meses de 1933 e os primeiros de 1934. Javier tinha 24 anos e foi apresentado ao poeta; assistiu ainda as apresentações de Lorca e os atores da companhia em um improvisado teatro, como conta Javier:

"Como decía, el el escenario del Teatro Avenida se instaló un precario tinglado de guiñol, a la manera popular. Todo fue supervisionado por Federico, el grupo de amigos com Fontanals a la cabeza - admás, compañero de viaje- $y$ algunos actores de la companhia de Lola Membrives, que secundaran a Lorca en el manejo de los muñecos durante la representación.(...) ofrecion una estupenda e inolvidable exibición de títeres de cachiporra, y la representacion conto com un repertório muy especial: Las Euménides de Esquilo, un entremés de Cervantes, y el Retablilo de Don Cristóbal."»

7 Medina, Pablo. Javier Villafañe. Antologia . Obras y

Recopilaciones. Buenos Aires, Editorial Sudamericana, 1990.

${ }^{8}$ Idem 
A partir dessa noite, relatada como mágica, Javier comenta que Lorca veio transmitir todo seu entusiasmo contagioso pelos bonecos, a paixão que tinha por sua terra andaluza e a impactante poesia do seu teatro. Lorca, por sua vez, comentou El Fantasma de Javier (publicados depois, em 1936 junto a outras peças com o título Títeres de La Andariega) em uma carta, afirmando que se tornaria um clássico da farsa para bonecos.

"La Andariega es una carreta tirada por dos caballos que lleva un teatro de títeres y la música de un organito.

Com Juan Pedro Ramos hicimos un pequeño tinglado, unas docenas de muñecos y dejamos un día la ciudad para irmos de pueblo en pueblo.

\section{(...)}

$Y$ asi fue. Cantaron los gallos y el alba descolgó su licero. Partó La Andariega rumbo al Norte y en el camino se desvió para el Sur. Po-que muchas veces el norte no está en el Norte."

Em suas andanças com o seu La Andariega puxado pela égua La Guincha, Javier com Mestre Trotamundos, seu boneco mais famoso, apresentavam textos de Cervantes, Lope de Vega e do próprio Lorca, sempre pedindo que as crianças fizessem desenhos após os espetáculos que depois ele guardava para mostrá-los às crianças da próxima cidade.

Nessas suas viagens seguiu colecionando desenhos Essa coleção ele trouxe ao Brasil na sua visita a Augusto Rodrigues. Javier acreditava no amor e na união, seu universo poético e mágico encantou crianças como llo Krugli, que ganhou da professora Helena Verrilho um livro com histórias de Javier que podemos supor se tratar de Títeres de La Andariega, publicado pela primeira vez

\footnotetext{
${ }^{9}$ VILLAFAÑE, Javier. Títeres de la Andariega. Buenos Aires, Ediciones Colihue, 1990.
} 
em maio de 1936, com cinco peças para teatro escritas anos antes ou El figón del palillero, de 1934, escrita em colaboração com Juan Pedro Ramos.

A inspiração para as histórias Javier ia experimentando no seu encontro com grupos de crianças de diferentes cidades. Certa vez, enquanto passava com a carroça, viu um grupo de meninos que plantavam plumas de pássaros e perguntou porque estavam fazendo aquilo ao que responderam:

- Plantamos plumas para que nasçam pássaros!

Ele mesmo diz que aprendeu muito com esses meninos; dessas e inúmeras observações de pássaros desde a infância escreveu História de Pájaros. Dentre outras publicações para crianças estão Ell gallo Pinto, De puerta en puerta, El caballo celoso, Maese Trotamundos por el camino del Quijote, para citar alguns de seus títulos.

Permaneceu fora da Argentina 18 anos sempre viajando, e em 1985 recebeu o prêmio Austral por sua obra literária.

Embora minhas observações possam parecer informativas demais, sempre houve muita curiosidade a respeito de Javier e pouco se sabia sobre ele no meio acadêmico, além de um artigo de Rubem Braga. Para mim, a importância em conhecer detalhes de sua infância e de sua história de vida é a mesma que me leva aos detalhes sobre a infância de llo Krugli, comprovando que a obra desses mestres estiveram em embrião desde sempre e a vida e a educação informal, foi terra fértil e água de chuva para eles. 
Ilo Krugli tornou-se artesão, artista plástico, como ele mesmo conta no poema Discurso sobre o Brinquedo, visto no capítulo 1, e com o seu grupo de teatro de bonecos seguiu viagem pela América Latina. Conheceu crianças que falavam línguas diferentes, dialetos de tribos e experimentou a comunicação com os desenhos e objetos. Esteve no Brasil em 1951. Professor, dava aulas de teatro de bonecos e de um exercício para as mãos surgiu $A$ História do Barquinho.

A História do Barquinho é um espetáculo realizado com as mãos e com panos. Um barquinho tenta se libertar do ancoradouro e apaixona-se por uma flor; levado pela correnteza do rio, chega até o mar e conhece um marinheiro que com a ajuda de uma âncora o ensina a navegar e reencontrar a flor. O espetáculo foi remontado muitas vezes e continua a ser apresentado com o nome de $O$ rio que vem de longe.

\section{Chegada ao Brasil}

"Ilo Krugli e Pedro Touron Dominguez chegaram ao Rio com um espetáculo tipo guignol tradicional, na linha dos irmãos Di Mauro e Mané Bernardo, com quem se formaram em Buenos Aires.(...) Com sua tenacidade Ilo e Pedro foram aos poucos desenvolvendo no Rio, um teatro além dos padrões até então existentes. Sob a direção de Gianni Ratto produziram Ubu Rei. Mais tarde apresentaram Retablo de Maese Pedro. Montagens que, para a época, foram uma novidade cênica." 10

A maneira de ver a criança, o inusitado uso da animação de formas e a proximidade com as artes visuais, llo Krugli trouxe de seu país e de suas

\footnotetext{
${ }^{10}$ AMARAL, Ana Maria. Teatro de bonecos no Brasil e em São Paulo de 1940 a 1980. São Paulo, ComArte, 1994. Pág.35.
} 
andanças pela América Latina com o Teatro de Cocuyo, que depois tornou-se Teatro de llo e Pedro mas que vieram a se fortalecer no encontro com Augusto Rodrigues e a Escolinha de Arte do Brasil, no início da década de 60 .

Em entrevista a Antônio Gonçalves Filho ele conta que conheceu nesse ambiente, pessoas como: Ferreira Gullar, Heitor dos Prazeres, Ismael Silva e Helena Antipoff (pedagoga russa que trabalhava com Piaget e para a fundação Pestalozzi)

Sobre o movimento Escolinhas de Arte do Brasil falaremos melhor no capítulo 3.

Em 1964, no Rio de Janeiro o espaço da Escolinha de Arte do Brasil reuniu as idéias de Javier de Villafañe, llo Krugli e Nise da Silveira.

Médica psiquiatra humanista, fundadora do Museu do Inconsciente na cidade do Rio de Janeiro, estudiosa do discípulo de Freud, o psicanalista Carl Gustav Jung, Nise da Silveira ${ }^{11}$ propôs, em 1946, um tratamento artístico para pacientes internos no Centro Psiquiátrico de Engenho de Dentro.

Nise da Silveira preocupava-se com o tratamento destinado aos seus pacientes, com o tratamento desumano e ineficiente imposto aos que sofriam internações nos hospitais psiquiátricos e tornavam-se, depois de longos anos de internação, desprovidos de individualidade. Pacientes crônicos perdiam a capacidade da comunicação; isolados, não tinham qualquer forma de expressão.

\footnotetext{
${ }^{11}$ SILVEIRA, Nise da. O Mundo das imagens. S. Paulo. Editora Ática,
} 1992. 
O grupo Ventoforte liderado por Ilo Krugli nasceu no Rio de Janeiro em maio de 1974, com a montagem do espetáculo História de Lenços e Ventos; o espetáculo trazia no bojo dos anos 70 uma linguagem inovadora para crianças, tratava a criança como ser inteligente, levando em consideração o modo como a ela aprende e vê o mundo; o universo simbólico.

"A criação dessa estética propõe uma especificidade do teatro para crianças, na medida em que pela primeira vez o espetáculo se fundamenta na compreensão da função simbólica na criança." ${ }^{12}$

No espetáculo os objetos e as mãos dos atores se transformavam em personagens. Lenços e Ventos ${ }^{13}$, de maneira poética, fala sobre liberdade e opressão $^{14}$. Em plena ditadura militar, o espetáculo abordava a história de Azulzinha, um lencinho azul, e Papel, uma folha de jornal, e o rapto de Azulzinha pelo Rei Metal Mau que a mantinha presa na Cidade Medieval. Para salvá-la, Papel de Jornal conta com a união de todos os lenços do quintal; juntos eles libertam os prisioneiros do Rei Metal Mau.

O espetáculo foi montado em dez dias, segundo o próprio llo Krugli, para o Festival e Seminário de Teatro e Dramaturgia Infantil de Curitiba, promovido pelo Teatro Guaíra, onde estreou. De volta ao Rio, foi sucesso de crítica e de público. Ainda sem nome, o grupo batizou-se pelo próprio espetáculo a partir de uma crítica de Ana Maria Machado, então colaboradora do Jornal do Brasil em que dizia que ventos fortes estavam soprando no teatro para crianças no Brasil.

\footnotetext{
12 KOUDELA, Ingrid. Jogos Teatrais. São Paulo, Ed. Perspectiva, 1995.

${ }^{13}$ MACHADO, Ana Maria. Novos prêmios para teatro infantil. Rio de Janeiro, Jornal do Brasil,1977.

${ }^{14}$ LOPEZ, Rui Fontana. "Lenços e Ventos", jogos que derrotam a tirania. São Paulo, O Estado de São Paulo, 17-01-1981.
} 
O espetáculo colecionou prêmios, para citar dois deles: Moliére, para llo Krugli, em 1976, e Melhor espetáculo infantil do ano em 1974, prêmio da Associação Carioca de Críticos Teatrais. Foi considerado um marco, um divisor de águas $^{15}$, um paradigma no teatro infantil, viajou para festivais importantes, realizando uma turnê ${ }^{16}$ pela Europa, sempre com críticas favoráveis ${ }^{17}$, que exaltavam o uso dos objetos, as cores e a transformação de objetos pobres em grande riqueza visual.

De 1974 para cá, llo Krugli se mantém à frente do Teatro Ventoforte e se mudou para São Paulo, em 1980. No Rio, alguns dos antigos integrantes do grupo que participaram da primeira montagem de Lenços e Ventos criaram o grupo Hombu, do qual participam ainda, dentre outros, Sílvia Aderne e Beto Coimbra, nomes que fazem parte da história do teatro infantil no país.

$\mathrm{Na}$ formação do elenco de São Paulo, outros profissionais vieram contribuir com o grupo formado por Sonia Piccinin, Márcia Correa, Paulo César Brito e llo Krugli. E como é característica desse tipo de linguagem coletiva, alguns dos integrantes permanecem ainda hoje: Roberto Mello e Marilda Alface, que em 1980 juntaram-se ao núcleo do grupo Ventoforte que chegou a São Paulo.

A cultura popular já era uma vertente estética do grupo desde o Rio de Janeiro. Tratava-se de uma resignificação do popular, uma característica dos anos setenta, dos jovens da UNE e do CPC. O resgate de cantigas e danças da

${ }^{15}$ BELINKI, Tatiana. Lenços ao sopro do Ventoforte. São Paulo, Folha de São Paulo, 13-07-1980.

16 Desconhecido. Suíça assiste em maio ao teatro infantil brasileiro. São Paulo, O Estado de São Paulo, 31-01-81.

17 BERNASCONI, Roberto. II vento, i bambini, la speranza. Lugano, Libera Stampa ( Quotidiano del Partito Socialista Ticinese, 09-06-1981. 
tradição folclórica, o visual, as cores, os bonecos agora mamulengos e alguns bonecos grandes, como os de Olinda. A integração com a comunidade também estava presente. De 1975 a 1978, Krugli dirigiu um centro de criatividade para crianças e jovens no bairro do Méier, no Rio de Janeiro, um trabalho desenvolvido junto à comunidade que originou o espetáculo $O$ mistério das nove luas. $\mathrm{O}$ espetáculo foi construído utilizando-se festas que se realizaram com a comunidade.

$\mathrm{Na}$ formação de São Paulo, dois maranhenses tiveram o importante papel de enriquecer o grupo com sua bagagem cultural: Pedrão do Maranhão e Tião Carvalho. Os rituais do bumba-meu-boi e as danças dramáticas como cocos e lelês, cacuriás e caroço fizeram parte de espetáculos, da formação dos alunos, das oficinas e cursos do Ventoforte.

Mas essa conquista, essa apropriação do popular já era um dos ideais dos jovens que fizeram a Semana de 22, o que faz com que os anos 70 se caracterizem como uma floração dessas sementes plantadas no tempo e na arte décadas antes.

Os movimentos artísticos brasileiros surgidos na década de 70 podem ser considerados desdobramentos dos ideais preconizados pela Semana de Arte Moderna de 22, assim, como antes foi considerada, a geração de 45. O grupo, da elite pensante paulistana, de jovens artistas brasileiros, se inspirou em movimentos europeus, como o expressionismo. Buscou uma estética nacional que viria a florescer em vários momentos e em vários segmentos das Artes. $\mathrm{Na}$ Literatura, com o regionalismo vindo de 45, Vidas Secas de Graciliano Ramos, e as obras de José Lins do Rego. Na poesia concreta preconizada por Ferreira Gullar. Nas Artes Plásticas, a Antropofagia, termo inaugurado pelos modernistas 
de 22, será retomada por Ligia Clark e Hélio Oiticica; na cenografia, por Lina Bo Bardi e Flávio Império. A Tropicália, na música, fortemente influenciada pelo movimento da contracultura. O Cinema Novo de Gláuber Rocha que com Terra em Transe retoma o manifesto modernista, e na pós-modernidade a $24^{\mathrm{a}}$ Bienal de Artes de São Paulo.

O grupo navega também nas mesmas águas de Federico Garcia Lorca, criando relações estreitas com a cultura popular de seu país. Valorizando essas formações simbólicas pertencentes a uma cultura, a uma nação, ao patrimônio cultural de cada indivíduo.

Oswald de Andrade, Tarsila do Amaral, Mário de Andrade e Heitor VillaLobos, para citar alguns dos participantes da Semana de Arte Moderna, deixaram como legado uma permanente forma de investigação, onde os elementos de diferentes culturas se misturam e criam uma estética nacional. Anita Malfatti e Mário de Andrade, influenciados pelo expressionismo e por movimentos europeus em arte e educação, valorizarão a expressão e a arte infantil.

O Ventoforte desenvolveu ao longo do tempo uma proposta de encenação que se utiliza de objetos, bonecos, cantos e danças da cultura brasileira, criando um teatro de festa, um brinquedo, um folguedo popular. O espaço de seu teatro é sempre inusitado: coretos e barracões, investindo na utilização de vários planos, com alçapões e cortinas. Uma proposta extremamente visual, de investigação de possibilidades do corpo do ator, aliada ao uso das formas de animação de objetos, das mãos e bonecos. Acredito que essa forma teatral possa ser decorrente da transição e transposição, a partir dos anos 70 , do teatro itinerante, andarilho, de carroça para os palcos fixos em forma de temporadas que nunca foram muito longas, durando sempre no máximo um ano em cartaz. 


\section{Histórias de Lenços e Ventos no contexto histórico dos anos 70.}

A década de 70, no Brasil, foi marcada pelo golpe militar de 1964, a instituição do Al-5, a aceleração do processo de modernização, o estímulo ao consumo desenfreado, possibilitando ao Estado forjar o mito do milagre econômico beneficiando o capital estrangeiro. Outra característica do período foi um isolamento dos artistas mais críticos à ditadura.

A idéia que vigorava no país pré-64, tanto para a direita como para a esquerda, permanece ainda: a de uma revolução por vir. Ressalto as palavras de Marilena Chauí $^{18}$

“(...) sempre prevaleceu, desde os anos 20, um modelo explicativo sobre a sociedade brasileira e sua história que favorecia a imagem de uma revolução por vir. São traços fundamentais desse modelo: ausência de uma burguesia forte, capaz de ser classe dirigente; ausência de um proletariado organizado e maduro, capaz de realizar uma revolução: presença de uma classe média capaz de se radicalizar em defesa dos interesses nacionais, sejam estes apresentados pela direita ou pela esquerda; ausência de uma ideologia nacional, idéias sendo sempre importadas sem respeito pelo caráter nacional; em decorrência das ausências ou privações anteriores e do lugar específico da classe média como funcionária do universal, isto é, do Estado e de suas instituições (particularmente o exército), o único sujeito histórico é o aparelho estatal, a partir do qual, no qual e pelo qual são realizadas as transformações." 19

18 CHAUÍ, Marilena. Seminários. São Paulo, Editora Brasiliense, 1983, pág. 67.

19 Idem. 
O espetáculo História de Lenços e Ventos trouxe uma interessante metáfora desse período. Contra o poder estabelecido é criado um quintal mágico no qual sopra a liberdade, onde tudo é construído artesanalmente e às vistas do público. O poder é uma sombra sem vida própria.

O próprio llo viera de experiências truculentas do golpe militar de 1973, no Chile. Pouco antes de voltar para o Brasil, Luís Martins, ator, amigo de llo, fora morto. Questionado, certa vez, do por que dos lenços, llo relatou que guardara a imagem, após o golpe, da bandeira de seu país (Argentina), azulzinha (sic), tremulando no céu.

Algum tempo se passaria para que no Brasil, em plena ditadura militar, Azulzinha fosse levada pelo Rei Metal Mau, dono da Cidade Medieval, uma cidade brilhante, linda, de metal, de cristal. Nela só entra metal, cristal, ouro, prata, seda, renda, veludo, brilhantina, purpurina, lamê, laquê, acrílico, aço escovado e nunca um pedaço de papel de jornal. ${ }^{20}$

Esses aspectos do espetáculo de llo Krugli não foram abordados nas críticas, nos jornais do período, pois constituem uma crítica à indústria, ao consumo desenfreado de massa que vinha sendo estimulado e veiculado pela televisão. O espetáculo, em princípio destinado às crianças, abordava temas complexos e políticos, utilizando-se de uma estética que rompia com padrões autoritários de verdades e lições de moral.

Uma forma de expressar a sua indignação, talvez contra o slogan da ditadura militar esse é um país que vai prá frente, em que projetos e leis

\footnotetext{
${ }^{20}$ KRUGLI, Ilo. História de Lenços e Ventos. Rio de Janeiro, Editora Didática e Científica Ltda, 2000.
} 
beneficiaram a criação do ensino técnico e, assim, o protecionismo às indústrias americanas.

Em Histórias de Lenços e Ventos, o personagem Papel, uma folha de jornal, enfrenta o Rei Metal Mau, da cidade Medieval, onde tudo é brilhante e industrializado, tudo nela é certo, arrumado e perfeito; lá só entra metal, cristal, ouro e prata; tão diferente do quintal onde moram os lenços e o papel de jornal. A metáfora parece clara, e ainda mais clara quando todos os lenços do quintal e os ventos de todo o mundo se unem para salvar Papel e Azulzinha; juntos são fortes e o rei Metal Mau é apenas uma sombra, um boneco, um pobre rei de Metal.

Do início da década de 70, o professor Marco Antônio Guerra ${ }^{21}$ delineia o seguinte panorama:

"O início dos anos 70 é marcado pela eliminação das vozes que não concordavam com os planos dos militares e das multinacionais. A supressão dos canais de expressão da sociedade civil (assembléias legislativas, congresso, etc), a censura aos meios de comunicação (jornal, rádio, TV, cinema, teatro, livro, etc) são apenas a parte visível de um processo de modernização autoritária, que visava integrar o país na produção capitalista internacionalizada."

É marca característica do período o movimento da contracultura, estético e comportamental, assumido por muitos jovens após o Al-5. Um fenômeno que despontou em âmbito mundial, quando uma grande parcela da juventude começa a negar os valores da civilização ocidental, suas tradições e maneiras de atuar da sociedade. O movimento hippie pregava uma ruptura com o

${ }^{21}$ GUERRA, Marco Antônio. Carlos Queiróz Telles. História e Dramaturgia em Cena (Década de 70). São Paulo, AnnaBlume Editora,1993. 
sistema através de uma vida mais livre, mais natural, dirigida pelo poder do amor, da flor e das drogas, e contra as armas, a guerra, o dinheiro e a posição social e tudo o mais que o establishment americano colocava como valores a serem ansiados e protegidos.

História de Lenços e Ventos estava inserido em uma verdadeira explosão de espetáculos para crianças; produções que também buscavam o jogo, a imaginação e a quebra da narrativa, procurando aproximar-se do universo infantil rompendo com o discurso autoritário do adulto emissor e da criança receptor. No entanto, o espetáculo do grupo Ventoforte se distinguiu deles e tornou-se um marco no teatro infantil. Quais seriam as especificidades, as diferenças que tornam o espetáculo do grupo Ventoforte uma referência e um marco histórico?

Embora a história do teatro infantil precise ser reconstituída, são vários os elementos que tornaram Histórias de Lenços e Ventos um marco no teatro infantil brasileiro. Dentre eles: o uso inusitado dos objetos e dos bonecos, a qualidade da música composta para o espetáculo e executada ao vivo, a liberdade enquanto tema, a ausência de explicações e do tom didático e professoral, a seriedade da proposta para crianças, a complexidade e rompimento da linearidade da narrativa (incluindo flashbacks, ruptura e fragmentação), a participação das crianças, o jogo simbólico e poético, a função da obra de arte enquanto expressão e visão de mundo de seu criador.

O espetáculo que inaugura o grupo e passa historicamente a ser uma referência para o teatro infantil configura-se como um momento de aprendizagem estética. Esse levantamento das características do espetáculo faz com que nos deparemos com categorias que explicitam conceitos e parecem cumprir as propostas de educação do filósofo americano Jonh Dewey propondo uma experiência significativa para as crianças. O conceito de experiência significativa 
refere-se à experiência, forma de interação pela qual os dois elementos que nela entram: situação e agente são modificados.

"A experiência é, nesse passo, pouco significativa para a vida humana. Não chegando à reflexão consciente, não nos fornece nenhum instrumento para nos assenhorarmos melhor das realidades que nos circundam. Grande se vai tornar a sua significação, quando se completa com o elemento de percepção, de análise, de pesquisa, levando-nos à aquisição de "conhecimentos" que nos fazem mais aptos para dirigi-la, em novos casos ou para dirigir novas experiências.

Todas as vezes que a experiência for assim reflexiva, isto é, que atentarmos no antes e no depois do seu processo, a aquisição de novos conhecimentos, ou conhecimento mais extensos do que antes, será um dos seus resultados naturais. ${ }^{, 22}$

Dewey propõe uma integração entre a vida e a aprendizagem. Um processo de reconstrução da experiência e da qualidade destas na escola propondo que a aprendizagem seja similar à vida: decorrência de um processo profundo, um mergulho para se chegar à alma humana. Quase como essas coisas de poetas...

Voltando às categorias, é possível analisar no espetáculo vários planos de significação desde a recusa de Manuel e Manuela, os bonecos encontrados dentro de uma mala. E que, recusando-se a fazer teatro dizem aos atores para fazerem eles mesmos o teatro.

22 DEWEY, John. Vida e Educação. Companhia Editora Nacional, São Paulo, 1959. 
Manoel e Manoela se trancam dentro da mala por dentro. A partir daí a curiosidade da criança vai sendo despertada para o plano simbólico em um jogo mágico.

Sem bonecos, os atores começam a procurar com o que fazer o espetáculo e encontram lenços, enquanto cantam os atores vão pendurando os lenços em um varal.

\author{
Eu sou de seda, \\ Eu sou de pano, \\ sou bordado de lua \\ Tenho flores de prata, \\ Eu sou de chita \\ Eu sou de lã, \\ sou dura engomada, \\ de flor floreada, \\ sou uma bandeira, \\ uma saia rodada \\ lencinho pequeno, \\ de espirro e de mágoa.
}

A letra de llo Krugli e a música de Caíque Botkay sugerem imagens do que é feito cada lenço e suas características. E a partir daí, manipulando os lenços, os personagens se apresentam:

- Era uma vez um pano vermelho brilhante. 
- Era uma vez um pano amarelo quadrado.

E assim cada lenço se apresenta e torna-se personagem.

A desobediência inicial dos bonecos Manoel e Manoela provocou a crise e em seguida a criação. As crianças se identificam com esses atores que a partir da recusa dos bonecos terão que brincar.

Envolvido pelo jogo, pela narrativa ágil que se desenrola trazendo novas crises e mais soluções criativas, o espectador é colocado em face de imagens sugeridas por música, sons, cores e poesia. Em uma perspectiva simbólica, observamos a preparação para o ritual do herói que tem de salvar sua amada.

Seria uma história como tantas outras, mas o herói é um jornal velho e sua amada um lencinho azul (de espirro e de mágoa ?).

Azulzinha tem desejos de individuação, quer voar. Em seu aprendizado, ela conhece Branquinho, que tem um monograma, é um lenço de família, enquanto Azulzinha é só um lenço do quintal. Branquinho a ensina a pegar corrente de ar para voar. Azulzinha cai em um balde d'água e se molha. Os atores interrompem a cena e enquanto ela seca no varal eles fazem uma cena de suspense. E então, cantando, eles anunciam um tema que acontecerá mais adiante.

Os quatro elementos também estão presentes na história, alguns exemplos: o herói ressuscita das cinzas, alegoria da Fênix; a chuva traz o conflito que molha o papel. $O$ ar é o elemento do sonho e da magia, todos os ventos do mundo são convocados e comparecem. A terra é representada pelo quintal. 
O mal é a sombra do rei, a luta travada entre o herói não é no corpo a corpo, é mais poderosa, acontece em outro plano, o da sombra expondo a idéia de sombra da psicologia analítica. E, ainda, o símbolo do dragão, elemento de destruição e de vitalidade dos pântanos.

Os lenços aprisionados na caixa estratosférica são libertados pelo herói e pelos atores, todos os personagens que foram aprisionados juntos constroem o dragão que ajudará a salvar Azulzinha para que possam voltar para o quintal.

\section{História de Lenços e Ventos e ressonâncias da Bauhaus}

..É necessário criar "símbolos", devemos fazer do Teatro o instrumento de "conhecimento do ser". Essa frase de Lothar Screyer, integrante do movimento da Bauhaus, define muito bem a linguagem cênica em Lenços e Ventos, o encadeamento da ação e os símbolos utilizados estimulam a percepção e a reflexão que são características e propósitos da obra de arte.

"'Expressão" no sentido lógico- apresentação de uma idéia por meio de um símbolo articulado - é o poder dominante e o propósito da arte. E o símbolo é do começo ao fim, algo criado. A ilusão que constitui a obra de arte não é um mero arranjo de materiais dados num padrão esteticamente agradável; ela é o que resulta do arranjo de materiais dados num padrão esteticamente agradável; ela é o que resulta do arranjo, e é literalmente algo que o artista faz, não algo que ele encontra. Ela vem junto com sua obra e extingue-se com sua destruição. ${ }^{23}$

O movimento artístico da Bauhaus, surgido em 1919, teve repercussão no pensamento dos jovens artistas brasileiros que criaram a Semana, que por sua

\footnotetext{
${ }^{23}$ LANGER, S. Sentimento e forma. São Paulo, Ed. Perspectiva, 1980.
} 
vez autorizou uma permanente investigação na estética brasileira. Traçando paralelos entre o teatro da Bauhaus e o teatro feito pelo Ventoforte, pode-se refletir sobre artistas e movimentos artísticos. Ambos têm raízes nas artes plásticas e partem do símbolo como forma de linguagem.

A Bauhaus foi o nome dado ao movimento cultural alemão (1919-1933) que se caracterizou por uma intensa atividade de ensino de arte com professoresartistas que se notabilizaram pela originalidade de suas concepções artísticas e métodos pedagógicos. ${ }^{24}$

O movimento surge por iniciativa de Walter Gropius (1883-1969), arquiteto, considerado seu fundador e como legado à história da Arte, a Bauhaus propõe na arquitetura, a adoção de formas e métodos de criação que serão os mais lembrados. Contudo, as inovações e as contribuições do movimento não se limitaram à arquitetura.

Em Weimar, em 1919, é lançado o manifesto da Bauhaus. Com seus ideais baseados no expressionismo, o movimento deseja completar o ser humano que se perdeu através do Capitalismo e das máquinas. Em um trecho do manifesto, pode-se ler claramente a proposta de integração do ser através do fazer artístico.

"O objetivo final de qualquer atividade criadora é a construção! Arquitetos, pintores e escultores, temos todos que reaprender a conhecer e a compreender as múltiplas facetas da construção no conjunto e nas diversas partes; só assim estaremos aptos a animar as obras com o espírito arquitetônico,

${ }^{24}$ EFLAND, ARTHUR D. A History of Art Education. Intellectual and Social currents in Teaching the Visual Arts. New York, Teacher College Press, Columbia University, 1990. 
fato que esquecemos na arte de salão. Formemos, pois, um grêmio de artesãos sem a arrogância classista que pretende levantar preconceitos entre artistas e artesãos! Desejemos, inventemos e criemos, em comum, a nova construção do futuro que será um todo: arquitetura, escultura e pintura... ${ }^{25 "}$

Nesse trecho do manifesto se destaca a intenção de que a Bauhaus pretendia ser uma cooperação entre a arte e a indústria mas que viria a desenvolver conceitos extremamente formais.

Para a formação dos estudantes, Gropius convocou os artistas mais modernos e célebres como Lyonel, Feiningger, Johannes Itten, Gerhard Marcks, Lothar Scheyer, Oskar Sclemmer, Paul Klee e Wassily Kandinsky.

A Bauhaus, historicamente enquanto movimento, é uma reação à Primeira Guerra Mundial. Walter Gropius tinha, participado do front e os professores chamados para lecionar tinham passado pelas tristes experiências da guerra: a perda de amigos e parentes e o abandono de seu país natal. Os nazistas e os conflitos pré-Segunda Guerra irão determinar o fechamento da Bauhaus, em 1933, em Berlim, onde havia se instalado depois do período em Dessau. Um significativo número de professores passa a lecionar nos Estados Unidos. Moholy-Nagy, no Instituto de Desenho de Illinois, Albers, no Colégio Black Mountain e mais tarde na Universidade de Yale, Gropius, no Departamento de Arquitetura da Harvard, Kepes, no Instituto de Tecnologia de Massachsetts. Esses professores transformaram o ensino de artes, desenho industrial, arquitetura e ofícios segundo os métodos estabelecidos pela Bauhaus. ${ }^{26}$

25 DÜCHTING, Hajo. Wassily Kandinsky 1866-1944. A revolução da Pintura. Köln, Alemanha, Benedikt Tashen Editora, 1994.

${ }^{26}$ EFLAND, ARTHUR D. A History of Art Education. Intellectual and Social currents in Teaching the Visual Arts. New York, Teacher College Press,Columbia University, 1990. 
De acordo com Franciscono, ${ }^{27}$ há uma similaridade entre o método usado por Itten e o usado por Cizek. Assim como Cizek, Itten ensinou arte para crianças. Em ambos os casos, sua pedagogia estimulava nos adultos o poder livre de criação, encorajando-os a confiar em suas próprias experiências e descobertas. Contudo, havia uma discordância entre eles. Gropius tendia mais a favor do racional, e de uma forma tecnológica de arte-educação, enquanto que Itten conduzia suas aulas para o expressionismo e valorizava o individual e a produção idiossincrásica. Em 1922, ele deixa a Bauhaus, sendo seu curso assumido por Lazlo Moholy-Nagy e Josef Albers.

\section{O Teatro da Bauhaus}

"A obra teatral produz a vida como a vida produz a vida" Schreyer

Lothar Schreyer e Oskar Schlemmer serão os responsáveis pelo teatro na Bauhaus, que se caracterizará por um teatro de investigação e uma infinidade de peças, pantomimas e balés, que segundo a pesquisa de doutorado da professora Maria Victoria Granero, ${ }^{28}$ configuraram alguns aspectos que atualmente se denominam Teatro Físico e Visual. E é ainda ela quem comenta a descrição de Eric Michaud no estudo sobre Schreyer, em que tudo deve voltar-se para o homem interior: cada forma, cor, som, palavra enquanto símbolo.

O teatro, para Schreyer, seria uma atividade pura e é através dele que se busca o conhecimento do divino.

\footnotetext{
27 Idem. pág. 216.

28 GRANERO, Maria Victoria V. M. A Aventura do teatro na Bauhaus. Tese de Doutorado apresentada à ECA/USP, São Paulo, 1995.
} 
O teatro ritual, o culto dramático e coletivo, com intenção de reencontrar o ritual cênico, a verdade interior, envolta em misticismo, são idéias apresentadas em algumas peças de Schreyer, tais como: Forças, A Morte de uma criança, Pecado e Crucificação.

Oskar Schlemmer, criador do Balé Triádico, propõe a busca do tipo universal; o teatro da Bauhaus vai então incluir o folclore, a dança, as máscaras e as marionetes, a música e o espaço cênico visual, a tridimensionalidade, renunciando aos telões pintados. A dança é uma estratégia de busca do espírito através do corpo e deseja fazer abstração de formas naturais. Além disso, Oskar Schlemmer está atento para a importância do inconsciente no processo criativo e, em julho de 1913, anota em seu diário.

"Atentem para o inconsciente! A mão faz inconscientemente coisas que a sutileza da razão jamais encontraria" 29

O grupo Ventoforte em sua trajetória de construção de uma linguagem cênica também busca o universal e integra os mesmos elementos propostos por Oskar Schelemmer. $\mathrm{O}$ inconsciente como matriz de imagens e gestos também é uma constante no grupo.

E, na citação abaixo parece que encontramos uma síntese do pensamento proposto para o teatro da Bauhaus.

"Em suma, tratava-se de atender uma exigência espiritual de Gropius, segundo a qual tornava-se necessário não perder de vista em nenhum momento

${ }^{29}$ SCHLEMMER, Oskar. Theatre of the Bauhaus. (Ed. e introdução de W. Gropius, tradução de A . S. Weisinger), Midletown, Wesleyan University. Press, 1961. 
que o ser humano é que dá vida às coisas, mesmo que estas se apresentem apenas na sua aparência material. Assim, os efeitos de luzes no cenário, as cores, os figurinos, a emissão do som da voz, o traçado geométrico na coreografia, tudo contém um sentido simbólico, estético, constitui o traço de união entre um estado de espírito e a gesticulação, entre o ordenamento dos cenários e de tudo o mais que compõe a peça em representação." 30

A Bauhaus configura-se como uma escola extremamente complexa; seu teatro muitas vezes foi mal interpretado e uma série de preconceitos foram sendo criados. Ela foi acusada de realizar e propor uma mecanização do teatro.

Minha intenção ao estabelecer paralelos entre o teatro da Bauhaus e do grupo de Teatro Ventoforte estão na sua fundamentação estética. O modo como foi levada para a encenação essa fundamentação, contudo, os diferencia. O uso do boneco, do corpo do ator, da música, o espaço cênico, o ritual, a idéia de professores-artistas e artista e artesão são uma constante, o espiritual, o divino e o inconsciente estão presentes tanto no teatro da Bauhaus quanto no grupo Ventoforte. As confluências de rios que deságuam na experiência do Movimento Escolinhas de Arte é composta pela Bauhauss, pela Escola Nova de Anísio Teixeira e pelo pensamento de Jonh Dewey.

A síntese proposta por Gropius no manifesto da Bauhaus e a integração das artes parecem quase idênticas às propostas de llo Krugli, mas a Bauhaus desejava uma arte formal, aliar-se à indústria e valorizar o artesanal. $\mathrm{O}$ grupo Ventoforte realiza espetáculos essencialmente artesanais, fazendo dessa prática a forma de linguagem para expressão de sua visão de mundo, buscando identidade e liberdade de padrões impostos pela indústria cultural. Esse aspecto

\footnotetext{
${ }^{30}$ GRANERO, Maria Victoria V. M. A Aventura do teatro na Bauhaus. Tese de Doutorado apresentada à ECA/USP, São Paulo, 1995.
} 
artesanal é responsável, dentre outros fatores pela originalidade de seus espetáculos.

"Junto ao uso das mãos, reconhecemos no trabalho de llo Krugli uma forte tendência artesanal, que se expressa, sobretudo na construção e destruição dos objetos formadores do espetáculo diante dos olhos do espectador (o sol que é pintado na hora em O Barquinho, o papel que é molhado e queimado em Lenços e Ventos). Se entendermos o artesanato como o trabalho do homem com as mãos visando a produção de um objeto exterior a ele, mas que carrega parte de sua força, de sua energia, então nos convencemos de que estamos próximos da compreensão de um dos centros temáticos do trabalho do Ventoforte, bem como a idéia que Krugli tem da arte do teatro como matéria moldada em conjunto visando um resultado que contém a humanidade em essência." ${ }^{31}$

Os anos 70 viram nascer muitos grupos de teatro que como recurso de criação se utilizavam da improvisação e da criação coletiva, características predominantes de grupos surgidos nessa época; alguns deles ainda sobrevivem e continuam a fazer teatro de boa qualidade, tanto para crianças como para adultos. É o caso do Grupo Tapa e do Oficina.

A improvisação e o teatro improvisacional vinham sendo praticados nos Estados Unidos desde os anos 60, e faz parte desse movimento o sistema de jogos da americana Viola Spolin, ${ }^{32}$ no seu Improvisação para o Teatro, traduzido no Brasil por Ingrid Dormiem Koudela.

31PIRAGIBE, Mário. Um percurso do teatro de animação através da experiência de llo Krugli. Pesquisa para o site. (http://www.cbtij.org.br/pesquisa_p3.htm) pág 13.

32 SPOLIN, Viola. Improvisação para o teatro. São Paulo. Ed. Pespectiva, 4르d., 2000. 
O jogo passa a ser parte integrante do espetáculo, e uma característica de algumas montagens produzidas para crianças nos anos 70 .

Um panorama histórico do teatro infantil paulistano e carioca foram pesquisados por Ingrid Domien Koudela e Maria Lúcia Puppo. Jogos teatrais e No reino da desigualdade traçam esse panorama. Em São Paulo e no Rio de Janeiro, o Centro Brasileiro de Teatro para a Infância e Juventude (CBTIJ) disponibiliza em seu site http://www.cbtij.org.br/pesquisa um vasto material sobre os precursores do teatro infantil, pesquisas sobre encenadores como llo Krugli e Oswaldo Gabrielli do XPTO, que foram material de pesquisa consultados para este trabalho; o Tablado e Maria Clara Machado e uma série de lançamentos de textos e cartazes comemorativos, além de outras informações sobre a história do teatro infantil.

O texto O casaco encantado, de Lúcia Benedetti (1948), é considerado o primeiro para crianças no Brasil. Desde os jesuítas, o teatro era didático, religioso, e moralizador, feito de adultos para crianças, o adulto como detentor do poder.

"Nos anos setenta revelou-se a continuidade de uma tendência preocupada em propiciar a iniciativa da criança, mostrando que ela é capaz de usar a imaginação." 33

Ilo Krugli passou, então, a atravessar as portas da vida junto ao grupo Ventoforte. Já são 28 anos de estrada criando espetáculos que continuam seguindo a correnteza poética. Nos próximo capítulo vamos nos aproximar do modo como ele cria seus espetáculos, ensina Arte para seus alunos e como o rio continua seguindo em novas confluências.

33 KOUDELA, Ingrid. Jogos teatrais. Ed. Perspectiva, 1995. 


\section{Cronologia de llo Krugli e de seu indomável Ventoforte}

1930 - Nasce em Buenos Aires Elias Kruglianski.

1936 - O poeta e dramaturgo espanhol Federico Garcia Lorca visita a Argentina.

1955 - Ilo Krugli vem ao Brasil pela primeira vez.

1958 a 61 - Com um grupo de teatro de bonecos viaja pelo Norte da Argentina, Peru, Bolívia de volta à Buenos Aires, nova partida até chegar ao Brasil.

1961 - Ilo Krugli vem ao Brasil com o grupo Teatro de Cocuyo. teatro de bonecos que se transformaria em Teatro de llo e Pedro. Trabalha com Augusto Rodrigues na Escolinha de Arte do Brasil, com Nise da Silveira no Museu do Inconsciente e com ela participa por dez anos do grupo de estudos sobre C. Gustav Jung e é um dos editores da Revista Quartênio.

1971 - A História do Barquinho. Direção: llo Krugli.

A montagem desenvolveu-se a partir de um roteiro de 1963, cuja proposta era a de servir para o exercício de expressão com as mãos. Segundo o próprio autor e diretor é um cântico à liberdade.

1973 - Golpe no Chile onde Ilo Krugli trabalhava junto ao grupo Manos.

1974 - História de Lenços e Ventos. Texto e direção de llo Krugli. Música de Beto Coimbra e Caíque Botkay. É montado para o Festival de Teatro de Curitiba. Uma forma de teatro onde a fantasia e a imaginação tinham grande força. Mas o boneco com llo é, quase sempre, um elemento a mais do que protagonista propriamente. Ainda neste ano, a crítica de Ana Maria Machado no Jornal do Brasil "Ventos Fortes no teatro para crianças no Brasil", dá nome ao grupo. 
1975 - Da metade do caminho ao país do último círculo. Texto e direção: llo Krugli.

- $\quad$ Premiado no Concurso de Dramaturgia Infantil da Fundação Guaíra.

1976 - As Pequenas Histórias de Lorca. Adaptação de textos de Garcia Lorca. Direção: Ilo Krugli.

- $\quad$ Prêmio Moliére para llo Krugli por História de Lenços e Ventos.

- Prêmio Um dos Cinco Melhores do Ano. Rio de Janeiro. Serviço Nacional de Teatro.

- $\quad$ Prêmio ACCA (Associação Carioca dos Críticos de Arte)

1977 - Mistério das Noves Luas. Texto: llo Krugli, Paulo César Brito e Sonia Piccinin. Direção: llo Krugli.

Montado a partir de cursos e festas com a comunidade enquanto llo Krugli foi diretor do Centro de Criatividade do Meyer no Rio de Janeiro.

- $\quad$ Prêmio Mambembe.

As Pequenas Histórias de Lorca inaugura em São Paulo o Teatro de Arena para Teatro Eugênio Kusnet.

1978 - O Serviço Nacional de Teatro cria a Companhia Dramática Brasileira, e monta-se um texto premiado pelo próprio SNT. A direção de Sonhos de um coração brejeiro naufragado de ilusão de Ernesto de Albuquerque é entregue a llo Krugli.

1979 - Sonhos de um coração brejeiro naufragado de ilusão estréia em Artigas, no Uruguai e recebe o prêmio Títere de Ouro, no primeiro Festival Internacional de Bonecos, recebe também o Prêmio Mambembe pela música/figurino. 
llo Krugli recebe o prêmio Mambembe para personalidade: e Mistério das nove luas é considerado o melhor espetáculo infantil do ano pela Associação Paulista de Críticos de Arte.

O Ventoforte radica-se em São Paulo fundando a Casa Ventoforte na rua Tabapuã.

1980 - Histórias de Lenços e Ventos é remontada e recebe o prêmio de melhor espetáculo do ano.

Teatro Ruth Escobar. São Paulo.

1981 - Luzes e sombras. Texto e direção: llo Krugli.

Misteriosos Pássaros de Barro. Direção: Oswaldo Gabrielli.

História do Barquinho, esse menino navegador. Direção llo Krugli.

1982 - História de Fuga, Paixão e Fogo. Texto baseado em Os fugitivos de Alejo Carpentier Adaptação e direção: llo Krugli.

1983 - Estou fazendo uma flor. Texto de Javier de Villafañe, Trsitan Klingsor e llo Krugli. Direção: Ilo Krugli.

Brinquedos da Noite. Criação coletiva do grupo Ventoforte. Direção: Paulo César Brito.

As Quatro Chaves. Texto e Direção: Ilo Krugli.

Caminhadas. Texto e direção: llo Krugli. 
1984 - Os Cisnes Selvagens. Adaptação do conto de Hans Cristian Andersen. Direção: llo Krugli.

Histórias de um Barquinho

As quatro chaves.

1985 - Labirinto de Januário. Texto e direção llo Krugli.

Estréia do novo espaço do Ventoforte à Rua Brigadeiro Haroldo Veloso, 150 em São Paulo, onde se localiza até hoje.

- $1^{0}$ Prêmio no Concurso Nacional de Dramaturgia Infanto Juvenil-INACEN

- Prêmio APCA Melhor Espetáculo Infanto Juvenil.

- Prêmio MOLIÉRE de Incentivo ao Teatro Infanto Juvenil.

- Prêmio MAMBEMBE para a Casa Ventoforte .

1986 - Qualquer Homem é Suspeito. Direção e Adaptação llo Krugli. A partir de textos do Romanceiro Gitano de Garcia Lorca.

Choro Lorca. Adaptação e direção de llo Krugli. Direção musical: Rui Weber.

A partir das peças de Garcia Lorca: Assim que se passarem cinco anos, A sapateira prodigiosa e poemas do Romanceiro Gitano.

1987/88 - Os Dois Irmãos ou O pássaro de fogo. Adaptação do conto dos irmãos Grimm.

Direção: llo Krugli

Direção musical: Edgar Lippo

A Tempestade ou o Punhal de Caliban. Texto: William Shakespeare. Direção: Ilo Krugli 
Viagem à Cuba. Apresentações no Teatro Nacional de Cuba do espetáculo Histórias de Lenços e Ventos.

- $\quad$ Prêmio Melhor Espetáculo Estrangeiro da temporada de Cuba.

1989 - Prêmio Tempo Ventoforte para comemoração de seus 15 anos, seminário e oficina As Quatro Idades.

1990 - O grupo Ventoforte participa do Festival de Teatro em Córdoba, Argentina.

1991 - O Mistério do Fundo do Pote ou Como Nasceu a Fome. Texto e direção llo Krugli. Música: Ronaldo Motta

A partir do trabalho realizado nas casas de cultura em conjunto com a prefeitura de Luíza Erundina, dá-se continuidade ao projeto iniciado em 1990, o Mutirão São Francisco, organizado pela comunidade dos sem-terra e pela prefeitura de Luíza Erundina.

1992 - O Ventoforte sofre pressões para que o projeto de alargamento da Avenida Faria Lima se realize, o Parque do Povo, espaço onde está a Casa do Ventoforte deveria ser demolido.

O Mistério do Fundo do Pote ou Como Nasceu a Fome.

1993 - Uma Rosa para Bela. Adaptação coletiva do conto A Bela e a Fera. Direção Wilton Amorim. Direção musical: João Poletto.

Espetáculo criado e dirigido por alunos e professores do curso Teatro da Imaginação, de llo Krugli 
1994 - Através de discussões, abaixo-assinados e graças ao prestígio que conseguiu ter, o espaço é tombado como patrimônio cultural, juntamente com o Parque do Povo, que inclui a Escola de Circo Picadeiro e campos de futebol de várzea.

Minueto do final do século ou O Príncipe Feliz. Direção e adaptação: Ilo Krugli. Direção musical: João Poletto.

A partir do conto de Oscar Wilde O príncipe feliz em comemoração aos vinte anos do grupo Ventoforte. $O$ espetáculo traz a bailarina e atriz Mariana Muniz atuando com Ilo Krugli.

1995 - Tragicomédia da Lua Branca. Adaptação de textos de F. G. Lorca.

Direção: Ilo Krugli

Direção Musical: João Batista Poletto

Histórias que o Eco Canta. Adaptação dos contos $O$ aniversário da Infanta, O rouxinol e a rosa e O gigante egoísta, de Oscar Wilde.

Direção: llo Krugli.

Direção Musical:. João Batista Poletto

7 Indicações para o Prêmio Mambembe.

6 Indicações para o Prêmio Apetesp.

- Prêmios APCA Grande prêmio da Crítica para llo Krugli, 20 anos de Teatro Ventoforte)

- Prêmio APCA Atriz Revelação para Eliane Weinfurther.

- Prêmio Mambembe de Melhor Diretor

- Prêmio Mambembe dos Cinco Melhores Espetáculos Infantis 
1996 - Sete-corações. Poesia rasgada. Remontagem de Qualquer homem é suspeito. Adaptação de poemas do Romanceiro Gitano de Lorca.

- Prêmio Mambembe dos Cinco Melhores Espetáculos Infantis

O Círculo de giz caucasiano. Texto de Bertold Brecht. Texto do prólogo de Plínio Marcos. Dir. Ilo Krugli.

1997 - Entre o céu e o mar. Texto de Pauline Milek. Direção Ilo Krugli.

Direção musical: João Poleto

* Espetáculo que não foi produzido pela Casa Ventoforte.

1998 - Participação no projeto Lorca na Rua do SESC. Com o espetáculo Setecorações. Poesia rasgada.

1999 -Mistério das nove luas. Remontagem

Teatro Popular do SESI.

2000 -Histórias de Lenços e Ventos. Remontagem. SESI São Paulo.

2001 - Portal das Maravilhas. Adaptação de textos de Cervantes. Direção: Ilo Krugli. Direção musical: Evandro Palma. Estreia teatro Ruth Escobar. Temporada Teatro Brasileiro de Comédia/2002.

2002 - As quatro chaves. Remontagem. Teatro Brasileiro de Comédia TBC. São Paulo.

- $\quad$ Prêmio APCA para llo Krugli. Melhor diretor. 


\title{
Capítulo III
}

\section{A porta da Terra e do Fogo}

\author{
“Vai pela Terra, tua mãe \\ Às vistas moradas, aos bons favores! \\ Doce como a quem soube dar, \\ Que ela te proteja do Nada! \\ Forma arcos sobre ele e não o destruas; \\ Recebe-o, Terra, acolhe-o! \\ Cobre-o com uma barra do teu vestido \\ Como uma mãe protege seu filho." \\ (Rig Veda, Grhyasutra)
}

"O amor é a primeira hipótese científica

para a reprodução objetiva do fogo

antes de ser filho da madeira,

o fogo é filho do homem....."

(Bachelard) 


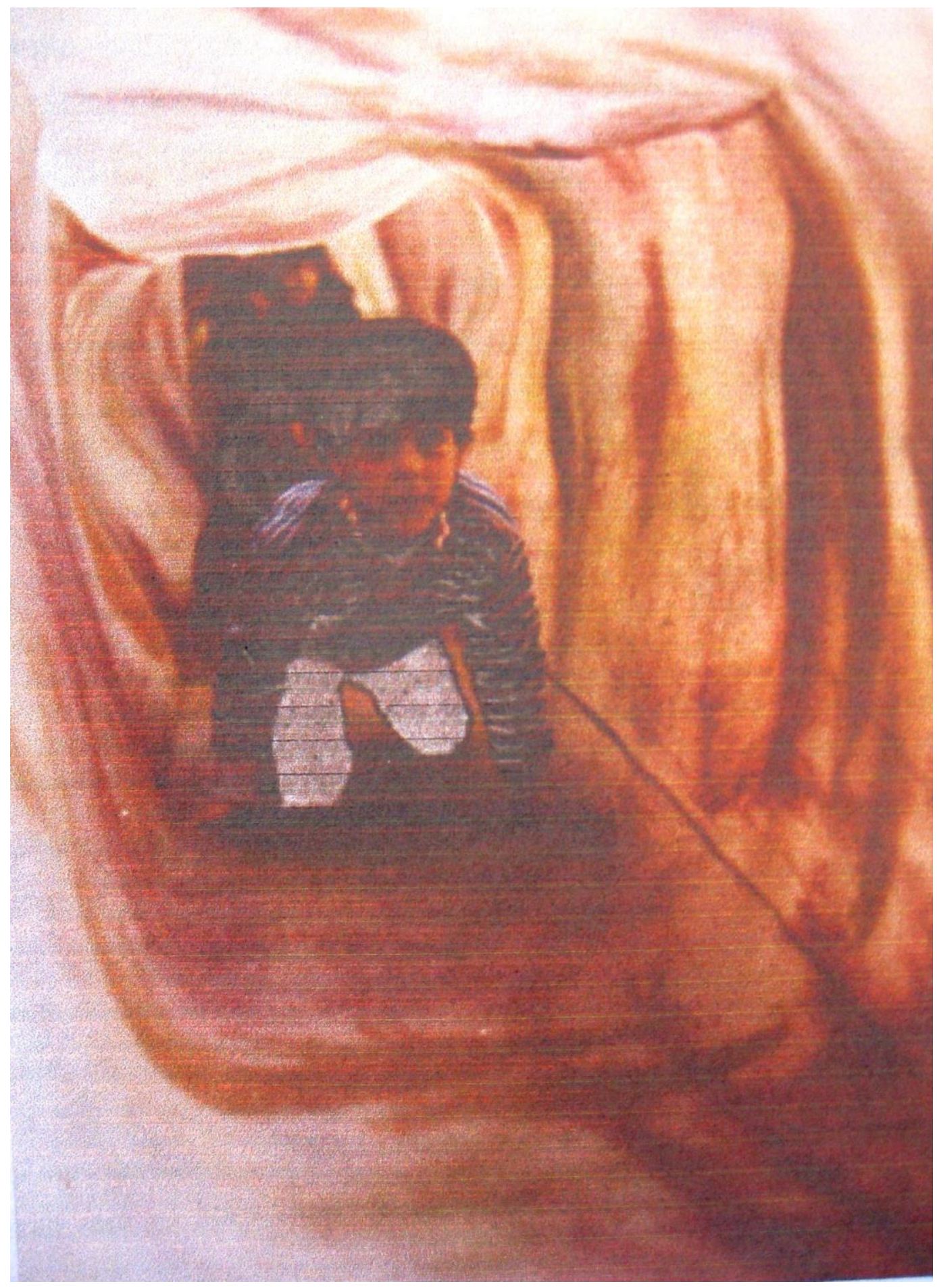

Espetáculo As quatro chaves. Foto: Roberto Mello. Arquivo Ventoforte 
A passagem pela porta da Terra e do Fogo deixa marcas profundas: nascimento, purificação, batismo, luz. Alunos e espectadores entram em contato com os vários símbolos propostos através da integração das linguagens: teatro de bonecos, dança, canto, artes plásticas e interpretação.

Nascido em meio à efervescência cultural dos anos 70, o grupo de Teatro Ventoforte teceu ao longo dos seus 28 anos de existência uma linguagem teatral que se relaciona à arte e à aprendizagem. Além dos espetáculos que criou ao longo desse período, exerceu intensa atividade pedagógica inserido e influenciado por movimentos artísticos que fundamentaram a história da arteeducação.

Para demonstrar propostas de aulas e oficinas e o fruto gerado por elas, foram recolhidos depoimentos de algumas pessoas que cursaram o Teatro da Imaginação, curso de formação de atores da Casa do Ventoforte. Esses depoimentos demonstram exercícios carregados de imagens, sinalizando a proposta pedagógica do grupo. Foram recolhidos a partir da memória. É inerente à natureza do recurso da memória selecionar imagens à luz de novas experiências. Contudo, os depoimentos são ricos em detalhes, também porque foi utilizado, em alguns casos, um diário de bordo, um caderno em que as aulas eram anotadas como um dever de casa. A partir dessa consulta, a memória pôde então se iluminar, se complementar, constituindo o material para análise; concebido das marcas profundas ou da ausência delas, conferidas pela aprendizagem em arte.

Os cursos e as oficinas para crianças, adolescentes e adultos são realizados na própria sede do grupo: A Casa do Ventoforte, no bairro do Itaim, em São Paulo, e também em casas de cultura, eventos, festivais e em projetos com comunidades e crianças de rua. Relatos minuciosos desses últimos foram desenvolvidos na dissertação de mestrado da pesquisadora Márcia Pompeu 
Nogueira $^{34}$ e tornarão a aparecer no capítulo cinco em depoimentos de antigos integrantes do grupo.

Uma equipe de professores-artistas sempre coordenados pelo diretor llo Krugli atua nos cursos para crianças, adolescentes e adultos. O diretor-pedagogo imprime a tudo o que faz a força da sua visão de mundo. De maneira coerente os cursos são compostos dos temas, conceitos e pela linguagem desenvolvida nos espetáculos ao longo de sua trajetória. A articulação do curso é poética e um de seus muitos objetivos é estimular o contato com a cultura brasileira e também com o "ser original". A Arte, e o processo criativo possibilitam ao sujeito a realização do desejo individual.

"Para sobreviver em determinada cultura o indivíduo precisa renunciar à sua individualidade - desejos, fantasias, instintos, animais, o que pode ser considerado como "pecado" erro, indisciplina - e assumir comportamentos socialmente aceitos pelo grupo.

A adaptação do sujeito à cultura é um processo de sofrimento, de desistência e abandono de si mesmo e da sua originalidade. Como moeda geral, intercambia-se o "ser original", reprimido através do esquecimento no plano do inconsciente, pela aquisição de modelos comportamentais positivados e socialmente valorizados pelo grupo." 35

Considero que o curso Teatro da Imaginação foi um importante centro de formação para um público misto: atores, artistas plásticos, terapeutas, médicos, professores e interessados em geral. Chego a essa afirmação de dois modos: a partir da observação e da formação nos anos junto ao grupo. Como já

\footnotetext{
${ }^{34}$ NOGUEIRA, Márcia Pompeo. Teatro com Meninos de Rua. Dissertação de Mestrado. ECA/USP, São Paulo, 1993.

${ }^{35}$ KENSKI, Vani Moreira. Sobre o conceito de memória. In. A pesquisa em Educação e as transformações do conhecimento. pág.147.
} 
pretendia iniciar uma pesquisa sobre o tema, a qual dei início na graduação, com a monografia de final de curso passei a recolher dados e informações. Me propus, ainda, a experimentar que um aluno formado pela escola de Krugli, poderia atuar como atriz ao lado de profissionais formados por escolas reconhecidas como a Escola de Arte Dramática e o Departamento de Artes Cênicas da USP, hipóteses que no meu caso vêm se comprovando.

Não me digam que não fiz nada de novo: a ordenação do material é nova! Já dizia Pascal. Organizei conscientemente minhas experiências para me expor à idéia de que a formação sensível do curso de Krugli, e que ele mesmo considera incompleta, poderia ser equivalente a outras instituições reconhecidas e respeitadas no ensino de Arte, desmitificando, assim, uma visão simplificadora com a qual o trabalho do grupo é abordado, muitas vezes filiada à má interpretação da livre-expressão.

Bicho-grilo, mago, bruxo do teatro infantil e outros adjetivos redutores aprisionam e classificam a partir de análise superficial, os elementos que compõem a linguagem cênica do grupo. Elementos os quais, serão úteis para responder à pergunta de como a arte é ensinada no Ventoforte e no que se relaciona a visão de mundo de seu criador na confluência dos rios que vêm desde muito longe trazendo a experiência do ensino técnico de Arte, a poesia de Lorca, o sonho de Villafañe e Herbert Read debaixo do braço.

Se por um lado é incompreendido, por outro não vê com bons olhos o ensino formal e regulamentado; se por um lado o ensino de arte é profícuo, por outro é concreto que nas condições materiais em que a escola do Ventoforte se desenvolve não pode oferecer sempre a possibilidade de sistematizar a experiência, ordená-la como ocorreu em Histórias que o Eco Canta, exemplo do qual falaremos no próximo capítulo. 
Espetáculos e aulas, cursos e oficinas deságuam em momentos de aprendizagem estética para os alunos e para quem frui dos espetáculos. A liberdade, tema de muitos deles, talvez de quase todos, confluência de suas experiências na Escolinha de Arte do Brasil, da sua práxis pedagógica e das características que foram se configurando na linguagem cênica do grupo.

Pode-se ler nas críticas de dois grandes nomes da crítica teatral, da história do teatro brasileiro: Yan Michalski e Sábato Magaldi, a intimidade do diretor, llo Krugli com o universo de Lorca e que, assim como o poeta alcança intimidade e valoriza a cultura popular de seu país.

"Com o seu ao mesmo tempo espanholíssimo e brasileiríssimo espetáculo, o Grupo Ventoforte contribui muito para a valorização da temporada de $1976(\ldots))^{36}$

"Já tivemos boas montagens do teatro de Garcia Lorca. Nenhuma, porém, conseguiu tanta intimidade com o universo poético do autor espanhol como as Pequenas Histórias de Lorca, trazida pelo Grupo Ventoforte do Rio de Janeiro para abrir o Teatro Eugênio Kusnet (ex-Teatro de Arena, na rua Teodoro Baima), $37^{\text {37 }}$

A proximidade do grupo com a cultura brasileira e com a tradição do teatro andarilho é articulada nos cursos e aulas de maneira original; busca a integração das artes. Mantém algumas semelhanças com movimentos artísticos e pedagógicos cuja proposta em Educação pela Arte tem objetivos, demonstra

\footnotetext{
${ }^{36}$ MICHALSKI, Yan. Pequenas Histórias. Grande Espetáculo. Rio de Janeiro, O Jornal do Brasil. 1976.

${ }^{37}$ MAGALDI, Sábato. Um grande espetáculo feito de coisinhas. São Paulo, O Estado de São Paulo, 1977.
} 
interesses e caminhos comuns ao Movimento Escolinhas de Arte do Brasil. Ilo Krugli deu aulas na Escolinha durante onze anos. Nos cursos da Casa do Ventoforte essas propostas se articularam segundo seus novos integrantes.

A integração das Artes têm o teatro como um núcleo. A imaginação é considerada o centro irradiador de toda a criação. Dança, música, literatura poesia, contos de tradição oral, contos de autor, contos de fadas, mitos - artes plásticas, teatro de bonecos e animação de formas são integrados na mediação da aprendizagem simbólica e na formulação das experiências interiores tornandoas concebíveis. As aulas se dividem em interpretação, danças populares, bonecos, contos de fadas e voz.

Aprende-se fazendo. Os músicos tocam ao vivo, os professores em muitos casos estão nos ensinando tradições com as quais convivem desde a infância. $O$ corpo vai ganhando expressividade a partir daquilo que poderemos chamar da cultura do afeto: o toque, estimulado pelas cirandas, as mãos dadas ou por outros movimentos pedidos pelas danças até a "umbigada", o toque, característico de algumas culturas e da nossa, vai sendo trabalhado, tem efeito terapêutico, como uma massagem coreografada.

Além das danças, o corpo é estimulado através de imagens, sempre um reflexo do movimento da Escolinha de Arte e dos métodos desenvolvidos por Maria Fux, amiga pessoal de llo Krugli, argentina é considerada a responsável pela sistematização da dança na Educação dentro do Movimento Escolinhas de Arte do Brasil. Os cursos de Maria Fux asseguravam o espaço e a importância da dança na educação enquanto linguagem, como possibilidade criadora e veículo da expressão. 
O trabalho realizado em dança reflete uma permanente preocupação com a cultura como tradição, termo que tomarei emprestado a Alfredo Bosi, uma vez que o conceito de folclore não daria conta da amplitude que o curso pretende ao desenvolver danças folclóricas, cirandas, danças do Maranhão e os rituais do Candomblé.

O corpo estar livre de tensões, espontâneo e desperto para dar vida às emoções e as imagens internas, representar essas imagens corporalmente são um dos primeiros objetivos dos cursos. O corpo é o veículo do teatro, instrumento trabalhado por exercícios de sensibilização, exercícios de sensorialidade e exercícios de encantamento.

As aulas de danças populares, festivas, nas quais é obrigatório, para as mulheres, usar saia. Dependendo da dança, os homens, em busca da movimentação corporal exigida, são estimulados a usá-la, como nas festas de São Gonçalo, por exemplo. Músicos ao vivo, lelês, cirandas, cacuriá, baralho. Uma festa a qual muita gente de fora vinha assistir. Tião Carvalho, cantor, dançarino, amo de boi, o que significa que ele é o dono do boi no auto do grupo Cupuaçú, da tradição popular maranhense, nosso professor nos levava para as apresentações no Morro do Querosene no bairro do Butantã, em São Paulo, onde dançávamos na praça com uma fogueira para nos iluminar.

\section{São Cosme e Damião}

\section{Damião cadê Doum}

\section{Doum foi passear no cavalo de Ogum}

Dois, dois, sereia do mar, dois, dois, mamãe lemanjá.

Dois, dois, sereia do mar, dois, dois, mamãe lemanjá. 
Festa junina, festa de final de ano e festa de São Cosme e Damião. Dançávamos junto à comunidade maranhense com integrantes do recém-criado grupo Cupuaçu, aprendíamos sobre as tradições culturais do Maranhão.

Muitas teorias poderiam aprofundar o que acontece com alunos de classe média, brancos que pagam suas mensalidades do curso de teatro no bairro do Itaim e em julho dançam horas seguidas em roda, em torno da fogueira cantando cirandas, cocos, lelê, cacuriás e toadas de Boi no ritual sagrado de vida e morte regido pela lua. Quando ela é cheia, em julho, tem festa! O suor escorrendo devido ao esforço em dançar no calçamento irregular e íngreme do morro; a catuaba - bebida típica do Maranhão; feita de vinho, cachaça, cravo-daíndia e mel - coletiva. A força do rito, do mito, da tradição. A vivência do ritual, da energia e força do coletivo são alguns dos ganhos efetivos, mas poderíamos enumerar muitos outros.

"Para que se dê a assimilação de um complexo será necessário junto à sua compreensão em termos intelectuais, que os afetos nele condensados sejam abranjidos, isto é, exteriorizem-se através de descargas emocionais. Os primitivos davam expressão a choques e traumas emocionais por meio de danças e cantos repetidos inúmeras vezes até que se sentissem purgados desses afetos". ${ }^{38}$

Além desses, há o exercício dos pés, o Bumba-meu-boi, assim como as outras danças dramáticas trazidas do Maranhão desenvolvem caminhadas em diferentes ritmos nos quais os pés são extremamente solicitados a executar os passos e deslocamentos sempre como quem estivesse deslizando. Em muitas culturas, como o teatro nô, o kabuki, japoneses e nos atores e dançarinos indianos kathakali e odissi, os pés são a base da representação no palco.

\footnotetext{
${ }^{38}$ SILVEIRA, Nise. Jung, vida e obra. Rio de Janeiro, Álvaro Editor, 1971.
} 
Essas experiências múltiplas estão voltadas para o teatro. Para se contar uma história controem-se bonecos que são utilizados junto ao ator, o boneco como objeto intermediário, sem tapadeiras, o corpo vai gerando formas, a música mobiliza o corpo e sempre coletivamente as histórias vão brotando a partir dos materiais propostos pelos professores. Essa integração busca identidade, memória, despertar a criança que está adormecida no adulto e na criança possibilitar espaço e linguagem para expressão. As escolhas são incentivadas pelos professores e depois cuidadosamente lapidadas, buscando desenvolvimento individual, o brincar, a espontaneidade, a construção, o artesanal.

As artes plásticas, o desenho, a pintura e a construção de bonecos e cenários estão entranhadas nos processos de aulas. A visão de inconsciente coletivo e de inconsciente pessoal, a expressão plástica desveladora do inconsciente, podem ser consideradas uma herança direta das pesquisas da Dra. Nise da Silveira. Estudiosa de Jung, um dos mais conhecidos discípulos de Freud, ela passa a fazer uma leitura das pinturas de seus pacientes buscando conteúdos submersos, que encontra expressos em forma análoga aos mitos. Mais uma vez falamos do símbolo como forma de expressão. A simbolização dos sentimentos. A partir dessa primeira etapa outras se seguiam incluindo aulas de pintura, fornecendo elementos da linguagem artística para que seus pacientes pudessem se expressar através dela.

A proposta artesanal pode ser analisada por diferentes olhares: o da sua função criadora, a função ritualística que possibilita o contato com a ancestralidade e a tradição, a visão de criança e a do materialismo histórico, nos seus aspectos culturais e sociais. Todas elas voltadas à educação e articuladas à proposta de aprendizagem estética do grupo Ventoforte.

Na função criadora, a vivência e a construção são possibilidades de simbolizar sentimentos, ordená-los em forma ainda que a princípio toscas. Além 
do tempo de estudo há um refinamento da percepção e da intuição, o que resulta numa elaboração desse material. Pelas imagens que brotam a partir do estímulo ao imaginário e experiências profundas de expressão há o desenvolvimento de um julgamento estético.

"O homem impregna suas ações com a presença de sua vida, com a carga de suas emoções e de seus conhecimentos. Dando forma à argila, ele dá forma à fluidez fugidia de seu próprio existir: estruturando a matéria, também dentro de si ele se estruturou. Criando, se recriou." 39

Na função ritualística, na festa, na coletividade, no fazer com as mãos retoma o papel do homem que atua no mundo e o transforma com suas mãos. Totens criados por várias civilizações e que animados, tornavam-se poderosos nos rituais sagrados.

"Vasculhando um pouco na memória e um pouco em anotações esparsas cheguei a uma experiência, que carrego ainda bem viva dentro de mim". As vivências de que participei nos quase dez anos em que estudei e trabalhei no Ventoforte ainda são chaves para a descoberta de muitos conteúdos. Vivências que longe de se esgotarem, são pontos de referência para percepções mais atuais.

1aㅡ Experiência: Estávamos trabalhando em 1990 com o tema do guerreiro, passando pela construção do personagem, sua história e objetos. A descrição é de uma das aulas iniciais, mais sensibilizatória.

06/08/90

Aula do llo

${ }^{39}$ OSTROWER, Fayga. Criatividade e processos de criação. Rio de Janeiro 
Movimentação pelo espaço, usar as mãos como guia. Escolher um movimento que goste e um que não goste.

(sentado) Procurar no corpo, percorrendo-o com as mãos, lembranças, sensações. Procurar o eixo interno, visualizá-lo (qual material).

Escolhe uma pessoa que você não conhece (a turma era mista de novos e antigos alunos), olha nos olhos, decide quem é um e quem é dois. Um pergunta para dois: Quem é você? Repetindo várias vezes. Dois responde sem pensar. Depois troca.

Sem comentar o exercício anterior, procurar um espaço, ou melhor, escolher. E tirando coisas do ar à sua volta, construir o guerreiro dentro de você, no seu corpo. Encontrar o eixo do guerreiro, construir uma muralha ou um castelo em volta de si. Tentar e conseguir sair de dentro.

Formamos um círculo e cada um imaginava um eixo central, onde pouco a pouco colocávamos as vestes e as texturas despidas do guerreiro. Terminamos a experiência num ritual, numa dança coletiva.

A interiorização do primeiro momento era profunda, mas o llo na condução tinha uma maneira muito acolhedora no lidar com a volta. Primeiro que trazia para o coletivo e para a elaboração de imagens. E quando acontecia de vir uma onda de sentimentos mais fortes ou choro, recebia com tranqüilidade, sem interpretações e com bom humor.

Eu era mais imatura que hoje e percebo que não me entregava inteiramente, terminando rápido a proposta e observando os outros, que entravam de cabeça e perduravam mais na experiência. Durante muito tempo eu acreditei que era uma questão de talento e capacidade que eu não possuía. Hoje, penso 
diferente, o envolver-se tem haver com disponibilidades internas, que carecem de tempo e certas vivências para despertá-las. Não é que não havia talento, é que eu não tinha a chave certa para abrir aquela porta. "Mas o que é incrivel, é que a vivência ninguém te tira, então você pode visitá-la indefinidamente e a cada reencontro descobrir novos e velhos significados."

(Luciana Coin, 29 anos, arte-educadora, atriz)

A visão de criança está no brinquedo e na construção artesanal, o aprender fazendo refletem sua práxis político estética ${ }^{40}$, uma ação social transformadora, já que o brinquedo está inserido na produção cultural, e fazendo artesanalmente, nega-se a aceitar a discriminação sancionada pela sociedade capitalista, distinguindo e subordinando a atividade manual à atividade intelectual.

"Através do brinquedo artesanal (e de outros tipos de artesanato) é possível avaliar-se a fragilidade de nossa democracia social e racial. No Brasil, desde os tempos da colonização portuguesa, a discriminação contra os negros e contra a atividade manual sempre se manteve associada. Historiadores clássicos, de formação liberal são unânimes em apontar essas mazelas da sociedade. O desprezo senhorial pela atividade manual era imenso e tinha dupla serventia: de um lado simbolizava a diferenciação social (estimava-se a superioridade na hierarquia social através da capacidade em se fazer servir pelo maior número de escravos); de outro, estigmatizava tanto os que tinham ocupação manual como todos os seus descendentes." 41

Um ponto chave da proposta pedagógica de llo Krugli é o ato de brincar. A brincadeira, o jogo simbólico, o faz de conta. Em cursos e oficinas para 40 VÁSQUEZ, Adolfo Sanches. Filosofia da práxis. Rio de Janeiro. Editora Paz e Terra, 2ª Ed. 1977. ${ }^{41}$ OLIVEIRA, Paulo Salles. O que é brinquedo. Ed. Brasiliense. $2^{\mathrm{a}}$ ed., São Paulo, 1989. Pág. 20. 
adultos e educadores, cria propostas facilitadoras da expressão espontânea através da brincadeira, do jogo.

Pretende, assim, instrumentalizar o adulto com o aprendizado ocorrido na infância, memória afetiva que traz material e experiências a serem desenvolvidas à luz da fase adulta. Ressalta ainda a identidade e a estima do educador e possibilita uma maior compreensão da criança, procurando romper com o discurso moralizante e o tom didático e professoral utilizado por muitos professores, habilitando-os a criar, a fazer conjuntamente, fazer com a criança.

A busca do conhecimento então perpassa por um autoconhecimento, uma memória concretizada em desenhos, exercícios, rodas de conversa e improvisações, valorizando aquilo que o adulto traz, estimulando a idéia da importância da autenticidade em sala de aula, da riqueza das experiências e da importância da preservação e respeito à infância.

A criança é vista como raiz arcaica do homem, sua presença estimula pesquisas, sua contribuição é respeitada. Reside no seu respeito à infância sua visão de mundo coerentemente articulada à sua proposta pedagógica, "o menino é o pai do homem."

“... atos infantis são sinais de forças e interesses em estados culminantes: a eles se aplica a máxima de bater enquanto o ferro está rubro. Porque se trata de uma questão de agora ou nunca. Selecionados, utilizados e cultivados, eles podem marcar uma encruzilhada definitiva na existência de um homem; desprezados, é uma oportunidade que se deixa fugir e que já não volta." 42

\footnotetext{
${ }^{42}$ DEWEY, Jonh. Vida e educação. São Paulo, Companhia Editora Nacional, 1959.
} 
Através da Arte, llo Krugli, em aulas e espetáculos, procura garantir à infância valores e faculdades humanas que poderão melhorar a inteligência, a qualidade da experiência e a manter o desejo, a capacidade de sonhar. Uma porta de acesso à beleza.

A brincadeira cantada, as brincadeiras de roda, de aculturação portuguesa, jogos tradicionais como são chamados, propostos para os adultos, crianças e adolescentes, são mais do que uma estratégia, buscam a espontaneidade, também são elementos culturais e simbólicos, marca de um povo, de uma nação.

Em consonância com a tradição poética lorquiana, a cantiga de ninar é valorizada e respeitada. Lorca, em uma das suas Conferências intitulada Comentário às Canções Infantis comenta sua pesquisa sobre as canções de ninar espanholas e a iniciação à poesia que refletem. Alguns anos depois ele viria a utilizar-se dessa pesquisa na belíssima cantiga de ninar de Bodas de Sangue.

"A mãe leva o menino para fora de si, para longe, e o torna ao regaço para que cansado, descanse". É uma pequena iniciação poética. São os primeiros passos no mundo da representação intelectual. Nesta canção (a mais popular do reino de Granada)

A la nana, nana, nana, a la nanita de aquel que llevó el caballo al agua y lo dejó sin beber. 
o menino tem um jogo lírico de beleza pura antes de se entregar ao sonho." ${ }^{, 43}$

Um outro brinquedo cantado que sintetiza muitos dos símbolos que são temas de aulas, cursos e oficinas é a ciranda, o círculo, a memória, o tempo, representados na ciranda que na cultura brasileira, especialmente em Pernambuco, como dança popular é dançada na praia, nas ruas e nos quintais.

$$
\begin{gathered}
\text { "A ciranda de estrelas salpicadas pelo céu, } \\
\text { é o luar da lua cheia, é o farol de Santarém, } \\
\text { não é lua, nem estrela } \\
\text { é saudade clareando } \\
\text { os zóinho de meu bem. }
\end{gathered}
$$

São sete estrelas cadentes, sete juras a jurar, três Marias, três Marias, cuide bem de se cuidar.... No amor, no juramento, que a estrela d'alva chora, de nos sete acreditar...."

O teatro é realizado com o Imaginário, para desenvolver o imaginário, e para isso acontecer estabeleceu-se a intrincada rede de relações entre os estímulos através do corpo, da música e da dança, das artes plásticas e dos objetos do cotidiano, o individual estimulando o coletivo e vice-versa.

43 LORCA, F. Garcia. Comentário às canções infantis. In: Conferências. Brasília: Editora Universidade de Brasília: São Paulo: Imprensa Oficial do Estado, 2000. 
"O teatro como forma de conhecimento, forma de desvendar enigmas, ajuda a conhecer a realidade e a si mesmo." ${ }^{44}$

A forma de conhecimento e de desvendar enigmas, expressa nessa frase de llo Krugli, é a forma que a aprendizagem estética pode oferecer, a imaginação, no conceito de pensar por imagens é uma possibilidade de configurar e significar uma experiência criadora ativa diante de um objeto do conhecimento. Procurando experiências que proponham sensibilidade, afetividade, intensidade para chegar-se à emoção, ao sentimento e exercitando a percepção, a intuição e o intelecto na definição das imagens, uma pedagogia da imaginação para que as imagens brotem sem que caiam num devaneio passageiro.

Uma vez que o corpo está desperto e disponível, a palavra e o som são estimulados junto ao corpo do ator. Exercícios de eco, uns contam para os outros trechos do texto com o qual se está trabalhando; cochicham procurando diferentes entonações, falam de longe, de perto, falam para as paredes, para as cadeiras de madeira, para os objetos, através dos panos procurando-se modificar o ritmo imprimindo características do objeto, adjetivos: leve, pesado, fugidio, etc.

Desenvolvendo, experimentando, tornando assim conhecida, as possibilidades de potência e volume da voz, a articulação e a intenção. Integrada ao corpo a voz é semelhante ao gesto, por isso, também é estimulada de maneira lúdica enquanto se cantam e dançam as danças dramáticas brasileiras e se contam histórias.

\footnotetext{
${ }^{44}$ NOGUEIRA, Márcia Pompeu. Teatro com meninos de rua. Dissertação de mestrado. ECA/USP, São Paulo, 1993. Pág.170.
} 
Voltando à frase de llo, em que o teatro é uma forma de desvendar enigmas, e à palavra expressa pela voz reflito sobre como Huizinga aborda a poesia como forma de jogo.

"Em qualquer civilização viva e florescente, sobretudo nas culturas arcaicas desempenha uma função vital que é social e litúrgica ao mesmo tempo. Toda a poesia da antiguidade é simultaneamente ritual, divertimento, arte, invenção de enigmas, doutrina, persuação, feitiçaria, advinhação, profecia e competição." ${ }^{\star 25}$

A partir daqui faço uma tentativa de desvendar conceitos das propostas de aula cultivadas por llo Krugli. Ao longo de tantos anos ele sistematizou uma série de exercícios. Peço licença para me aventurar mais uma vez como aprendiz de feiticeiro e registrar algumas dessas propostas de aulas.

Alguns exemplos dos temas para as aulas/propostas, experiências que propõe símbolos, procurando articular-se, sempre, de maneira poética são:

- Os quatro elementos da natureza. Entendidos como matriz arcaica do imaginário. Para se chegar à história de cada um, pois busca a identidade e a memória como fios condutores da expressão e estão relacionados à origem do ritmo no teatro.

“... ritmo cardíaco, respiratório ou muscular, influência das estações e dos ciclos lunares, propõe dois tempos: inspiração/expiração, tempo forte(marcado)/ tempo fraco (não-marcado). Para a ação teatral- ao menos na

\footnotetext{
${ }^{45}$ HUIZINGA, Johan. Homo Ludens. São Paulo, Ed. Perpectiva, 2001.
} 
dramaturgia clássica- é válido o mesmo esquema: ascensão/queda da ação, nó/desenlace, paixão/ catarse. ${ }^{46}$

- Caminhadas imaginárias e mergulhos nos elementos.

Como demonstração segue o relato de minhas aulas no início do curso:

Eu tinha 19 anos, vinha de experiências em teatro amador com decorar textos e fazer "laboratórios"; deveríamos levar objetos da Terra, desenhávamos nossas silhuetas e nascíamos da Terra. Lembro de ter sido menina-planta e não ter conseguido transformar a silhueta em personagem, meu objeto era uma colher e uma bacia e era meu primeiro semestre. Travava, ficava imóvel e não conseguia usar o objeto como fora proposto. Ao final da aula, atenta, a professora Fátima, então da equipe do Ventoforte, comentou os exercícios e propôs que nos transformássemos em bonecos de barro e caminhássemos sentindo nosso corpo feito de barro.

No decorrer da proposta lembro-me do exercício da Maria, uma colega de turma que gritava "Bichos escrotos, no esgoto tem cocô, sou um bicho escroto". Ela rastejava pelo chão e atirava nos outros pinhas de Natal (o objeto dela da terra), soltava uns gritos e se escondeu num canto. Embora não estivesse usando maquiagem nem figurinos, sua aparência assustou-me, desfigurava-se com caretas de angústia, se passávamos pelo canto onde estava nos "atacava". Eu mesma, sem ter elaborado, como era de praxe para mim fazer as coisas na época, corria de medo.

$\mathrm{Na}$ evolução da proposta em que construíamos casas para nossos personagens com panos e objetos: escadas, latas, pneus, etc, Maria construiu um túnel. Mais assustadora ainda, gritava lá de dentro e continuava a nos atirar pinhas, eu menina-planta de asinhas continuava seriamente em dificuldades para

${ }^{46}$ PAVIS, Patrice. Dicionário de Teatro. São Paulo: Ed. Perspectiva, 1999. 
sustentar minha construção de personagem, muito inspirada na história em quadrinhos Orquídea Selvagem. A "casa" da Maria era muito perto da minha, o que fez com que a minha fosse constantemente destruída pelas pinhas (os cocôs) - e eu que deveria ficar imóvel na minha árvore...- até o dia em que ela me raptou. Foi horrível. Mas daí nasceu o conflito, o nó para a ação que desenvolvemos a partir da improvisação até constituir-se em um roteiro de cenas, que pela sugestão da professora, seguiu a estrutura do mito do rapto de Pérsefone por Hades.

As aulas trouxeram espontaneidade e originalidade para minhas ações, minhas imagens começavam a surgir livres de padrões e esteriótipos, aprendi a improvisar e a aceitar o que surgia buscando forma; ainda com medo de parecer ridícula ia incorporando as ações que surgiam por medo da Maria e contracenava com o outro (fui impulsionada a isso). Construímos um roteiro de cenas a partir da improvisação e estávamos iniciando uma experiência em uma dramaturgia dos gestos, sem palavras.

- O caminho

É um tema muito caro a llo Krugli, a espiral (às vezes desenhada no chão) conduzindo a história como um caminho, simboliza a experiência da vida, o tempo, o passado, o presente, o futuro.

- Os sonhos

"Especialmente nessa proposta, a de representar sonhos coletivos, o Ilo falou bastante! Pontuou cada cena, valorizou diversos aspectos: estéticos, simbólicos, criativos, etc. 
Escolhi uma dessas aulas para contar porque entendi, ou cheguei perto, daquilo que o llo falava sobre imagens interiores, simbólicas e coletivas, tanto que a memória se deu na seguinte ordem: primeiro eu me lembrei da imagem, depois do sonho, depois do processo, depois das falas do llo e por último, do significado renovado dessa vivência, ou seja, do grande aprendizado que tive.

Quando me reuni com meu grupo, cada um falou espontaneamente sobre seus sonhos, encontrando personagens e situações comuns. Decidimos costurar algumas cenas e acrescentar outras ações das personagens a elas.

$\mathrm{Na}$ nossa história, caminhávamos numa mata (companheiros), procurando caminhos. Havia um guia com bandeiras espalhadas pelo corpo, inclusive sobre seu chapéu que indicava esses caminhos. Ele havia sido encontrado numa encruzilhada. Ele distribuía bandeiras para orientar melhor os caminhantes.

Depois de muito andarem, eles chegaram lá no alto, no lugar onde o sol se põe. No lugar onde o sol tem nome e identidade.

A imagem que guardei na memória foi a do instante em que o sol morreu. Era preciso que ele morresse e ele sabia disso. Esqueci de dizer que os viajantes carregavam uma roda (aro de bicicleta). Quando eles giravam a roda faziam a passagem de um sonho para outro, ou seja, a roda, do tempo, costurava os sonhos de cada um. Uma de nossas colegas era a Verônica, uma pessoa talentosa e pequenina. Na cena final, a do instante em que o sol morria, ela se deitou sobre a roda do tempo e girou até parar. 
Eu fazia o homem das bandeiras, guia dos caminhos.

O llo falou da força simbólica que tem a bandeira, da plasticidade da roda girando e de sua função de código cênico, indicador de tempo e mudança e da poesia do sol morrendo.

Uma das críticas que o llo fez a um grupo que reproduziu o seu sonho foi a escolha linear e literal de representação que fizeram.

"O sonho não precisa ser explicado assim como o teatro também não!

O excesso de racionalidade limita o desenvolvimento criativo e expressivo!"

(Mônica Huambo, 29 anos arte-educadora de música)

Buscando imagens originais e estimulando a valorização do inconsciente como um reservatório pessoal, um arcabouço de imagens e deflagrando propostas de criação.

- O círculo. O círculo com quatro portas

"Naquele dia o vento assoprava leve no jardim do teatro. Quando cheguei, nenhum cachorro na praça central. Última aula com Ilo Krugli no ano de 92. Éramos 8 ou 10 alunos. Trabalhamos com os quatro elementos todo o ano, ar, água, terra e fogo. O quinto elemento, a poesia, trabalharíamos junto a Lorca no outro ano. 
A aula foi no Teatro dos Pés. Uma imensa lona amarela servia de cortina. O chão cinza do cimento recém-passado. Naquele ano havíamos trabalhado o eixo, muito exercício de imaginação, polaridades do corpo, percursos; sempre com os músicos dialogando com os atores. Os oráculos no jardim, a natureza circundante. Era final da tarde, me lembro muito do ar preechendo todos os espaços. Meu pulmão. As folhas repousadas nos galhos da árvore. A cachorra Tuti passou e sorriu, mas nós estávamos sérios.

Sempre sentávamos em roda no começo (ouvir a proposta) e final da aula (falar dos núcleos). Primeira proposta foi imaginar que pegávamos coisas diferentes com as mãos e derramávamos para a terra. Cada ser imaginado propiciava um ato do braço.

Depois a caminhada no espaço do palco. Objetos referentes aos elementos. Eu usava um cabide para capturar o ar. Os outros todos muito loucos. (O percurso, o objeto e o outro, seria a síntese?) deixamos oferendas no centro do palco dançando ciranda.

Caminhamos para o jardim cantando "Vem vento caxinguelê..." e começou a ventar e os eucaliptus dançavam soberanos no perímetro do terreno. Um círculo de gentes dentro de um círculo de árvores. Três teatros, um coreto, desenhavam uma mandala. Todos nós dançando com o vento!

Eu nunca me esqueci desta aula, foi o fechamento de uma seqüência de rituais sem perder a relação com o ato. Entrar no Ventoforte e fazer teatro integrando as artes mudou o rumo de minha vida. Tive espaço para a poesia."

(Paulo Farah André, 36 anos. Ator, cenógrafo, educador) 
- O Mapa da vida.

"O mapa da vida: a proposta era desenhar em três pedaços de papel a sua história de vida. No primeiro, que era colocado no centro, desenhamos uma linha, um caminho cheio de imagens daquilo que sabíamos de nós mesmos desde que nascemos. No segundo, que ficava à nossa esquerda, desenhamos como eu era antes de nascer e, no terceiro, na nossa direita, para onde vou, o horizonte.

Lembro-me que rabiscamos muito os papéis, antes de desenharmos alguma imagem definida neles. O professor era o llo Krugli e passamos umas duas ou três semanas trabalhando no nosso mapa. Sempre, a cada parte do processo de confecção do mapa, tínhamos um momento de olhá-lo de perto e depois de longe e depois os dos outros de perto e de longe. Essa experiência de olhar de perto e de longe é muito importante. Você vê de diversas perspectivas a sua produção e a dos outros, o todo e as partes, o conjunto e os detalhes, e esse ir e vir é muito poético, quando vivenciado.

Fazendo este mapa, lembrei-me de diversas coisas da minha vida que não sabia que sabia. Uma imagem que ficou guardada foi a da vista pela janela do nascer-do-sol, que desenhei numa parte do meu caminho-linha da vida, quando lembrei que havia passado toda a minha infância olhando o nascer do sol da janela da minha casa, sozinha. Era um momento de solidão para mim, onde todos dormiam enquanto eu já estava acordada e minha companhia era o sol.

Contávamos para todos e para o llo o que havíamos desenhado e ele, cuidadosamente, conversava, via as imagens, deixava que falássemos sem "psicologizar" os conteúdos que apareciam ali. Tudo era resolvido pela arte e isso 
é realmente encantador. É fascinante poder fazer arte daquilo que é, a princípio seu e depois, do mundo.

Lembro-me que junto comigo, fazendo o mapa, havia um rapaz. Ele desenhou em seu mapa diversas coisas de preto, fez tudo muito pesado e foi contando sua história para nós. Não me lembro exatamente como era seu desenho, mas era forte, marcante e conforme nos contava seu mapa, revelou seu sofrimento por ser homossexual e, conforme falava de seu mapa, ia transformando ele, colocando cores diferentes, refazendo-o. Ele era um grande artista, muito bom ator e figurinista.

Esta é uma das lembranças: a possibilidade de fazer e olhar histórias através de imagens profundas e marcantes, que sozinhas, não são importantes, mas, junto com outras histórias desenhadas, produzem transformação e arte."

(Tatiana Bichara, 26 anos, psicóloga social.)

- Os sete corações. Exercício inspirado no poema de Lorca do Romanceiro Gitano. Sete corações tenho, mas não acho o meu...

- Festa. A participação nas festas com a comunidade. Cantigas e cirandas.

— O quintal, espaço esquecido.

- A passagem pelas portas de entrada e de saída, etc. 
— Os opostos como dia/noite, claro/escuro, vida/morte, lua/sol, quente/frio, seco/molhado, luz/escuridão, inteiro/metade, verdade/mentira entre outros.

As propostas do caminhante, do guerreiro. Andar na ponta dos pés, com os pés inteiros, sentindo os lados, os calcanhares. Pegar o ar com as mãos em cima e soltar embaixo, procurar o eixo sentados longe um do outro: metade dia, metade noite, colocar essas imagens dentro de si, enrolar-se em si mesmo e criar o guerreiro. Fiz um personagem masculino, cavaleiro que lutava pela honra do rei. $\mathrm{Na}$ sequência das aulas, os guerreiros caminhantes encontram o animal, ganham seus talismãs, criam sua vestimenta partindo de uma substância feita de cores e morrem. Meu personagem recebeu as asas negras da Morte e um assobio, no lugar de braços tinha asas (inspirados em histórias em quadrinhos para adultos), quando matava horrorizava-se de si e de angústia morreu.

Em pé, llo organizava as cadeiras de madeira e determinava em frente de quem cada um ia morrer.

Cadeiras de frente uns para os outros com o espaço do palco entre elas, a proposta é sintetizar a história do guerreiro nesse trajeto, contando para o colega que está à sua frente, sentado. Morrer aos pés dele. Olhando nos olhos do outro, renascer com a pergunta do colega: Por onde anda o sonho do dia e da noite? E algumas palavras são a resposta: no circo, na tempestade, no vento, na areia, no rubi, no horror...

$\mathrm{Na}$ roda final, Ilo pedia que fosse escolhido um núcleo da aula. Uma imagem, e que ela fosse descrita em palavras, ás vezes uma única palavra. A partir daí comentava o que tinha visto. 
$\mathrm{Na}$ seqüência das aulas as imagens transformavam-se em bonecos, de mão, vara ou sombra, em desenho, em coreografias e em histórias, às vezes, essas eram escritas e procurava-se um mito ou conto de fadas que ela pudesse sugerir, cantigas eram compostas pelos professores-músicos, outras resgatadas pelos alunos.

- Buscar imagens nas letras das cantigas propostas, toadas, cocos, lelês, cirandas, e o próprio repertório do grupo de músicas criadas e recolhidas para os espetáculos:

\author{
Meu pontão de ouro, \\ Maria alumeia, \\ O sereno brilha, \\ O pontão balanceia ${ }^{47}$
}

Os depoimentos recolhidos auxiliam a compreensão das propostas de aula, são demonstrativos e ampliam a visão da proposta pedagógica em diferentes matizes. O roteiro para sua elaboração pedia que fosse descrita uma aula qualquer, de qualquer um dos professores do curso, mas que pudesse ser descrita em detalhes e da qual se lembrassem da proposta inicial da aula ou de uma seqüência de aulas, do que realizaram, das relações com os outros, o que o professor apontou como leitura da proposta realizada e se quisessem comentar a experiência.

É importante frisar que a coleta de depoimentos me ocorreu depois do exame de qualificação para essa dissertação, justamente na tentativa de esclarecer para o leitor os processos de criação propostos. Eu já havia feito o

\footnotetext{
${ }^{47}$ Trecho de toada de Bumba-meu-boi cantada no Morro do Querosene por Ana Maria Carvalho.
} 
levantamento dos temas e verifiquei, na análise dos depoimentos que eles vêm a corroborar as marcas profundas das experiências ocorridas há quase dez anos atrás. E sem que houvéssemos combinado, traziam os blocos de temas das aulas que já haviam sido citados, nenhum novo surgiu fazendo com que eu tenha possivelmente cerceado a maioria deles e compreendido que podem surgir recombinações infinitas.

Buscando transformação através do movimento de imagens internas, a expressão é trabalhada, desenvolvida e orientada pelos professores, que tomam decisões dramatúrgicas para se chegar a uma síntese, para que de fato haja transformação, aprendizado, conhecimento de si, do outro e da linguagem teatral.

Há uma permanente busca por uma atitude ativa de escolhas, as aulas são discutidas com os alunos num processo participativo e dinâmico. Os exercícios sempre se transformam de acordo com os diferentes grupos. Enquanto trabalhávamos, às vezes, por três horas seguidas, os músicos tocavam.

"Na aula havia música ao vivo e o llo comandava a seqüência de movimentos, orientando sempre com base nos quatro elementos.

Em determinado momento éramos a água, experimentávamos 0 movimento leve e suave de ser água. A música sempre de acordo com a proposta. Da água passávamos para o fogo e assim por diante, até percorrer os quatro elementos.

Eu me lembro de ter dançado bastante, de ter percebido o quanto os movimento podem ser redondos, a partir de um estímulo e o quanto podem ser pontiagudos a partir de outro. $O$ quanto há de paixão e quietude em cada 
elemento da natureza. O peso e a leveza do nosso corpo. A ocupação dele no espaço.

As outras pessoas do grupo também dançaram bastante, mas não me lembro bem o que faziam. Era como se fossemos todos uma coisa só.

Essa aula me deixou lembranças muito fortes. Foi muito divertida, muito gostosa. A música era muito boa e o ambiente que se criou era extremamente agradável, propício para a imaginação sem limite, a experimentação dos nossos próprios recursos corporais e o exercício da percepção rítmica e poética de cada elemento."

(Mariana Laura Corullón, 24 anos, atriz)

Sentado, nos degraus da escada de madeira do Teatro dos Pés, llo Krugli observa muito atentamente, vai até os músicos e parece cochichar alguma coisa. Terminado o exercício, comenta um a um e pede que os exercícios sejam refeitos segundo suas orientações. Sugere que todos tenham um caderno e que em casa deve-se anotar imagens e desenhá-las. Ou, interfere constantemente, trabalhando a repetição em grupos e propõe que os resultados sejam mostrados de uns para os outros.

“ (...) Enfatizando a importância do jogo como gênese da metáfora instrumento primeiro da aquisição do conhecimento"48

\footnotetext{
${ }^{48}$ MORAES, Marina Célia Dias de. Metáfora e pensamento: considerações sobre a importância do jogo na aquisição do conhecimento e implicações para a educação pré-escolar. In. Hishimoto, T. (Org) Jogo, Brinquedo, Brincadeira e a Educação. São Paulo, Cortez Editora, pág, 46.
} 
$\mathrm{Na}$ medida em que tem a visão do Homem como ser simbólico, sua trajetória é norteada pelo desenvolvimento e aprofundamento do símbolo, da poesia, da metáfora na construção do pensamento e da linguagem; da articulação dos elementos integrantes da linguagem teatral que remontam às origens do teatro.

E tem a visão do homem "concebido como sujeito que interpreta o mundo a partir de esquemas de pensamento que são redes intrincadas, afetivas, cognitivas, conscientes e inconscientes, elaborações internas de cada um, construídas dentro e a partir do contexto cultural e social. O contexto cultural, por sua vez se estrutura por meio de representações coletivas simbólicas, que vão ser ao mesmo tempo, alimento e produto do pensamento humano (linguagem, arte, religião, mito e ciência) a realidade é assim construída, nunca capturada diretamente por um pensamento linear ou um discurso explícito" 49

O espaço de seu teatro, toda sua proposta pedagógica é construída por metáforas, pela poesia, numa pesquisa delicada e profunda, construção de uma linguagem que se comunica através do jogo poético e simbólico, assim como é feito o ritual do teatro. Cada elemento integrante da linguagem é desenvolvido metaforicamente.

\section{Concepção de teatro para crianças em diálogo com idéias formadoras: a livre expressão e o movimento Escolinhas de Arte do Brasil}

A compreensão de como a criança vê e apreende o mundo é a condutora da forma de seu teatro, as portas são abertas para que cada elemento: texto, ator, platéia possa ser experimentado como um ritual.

49 Idem. Pág, 47. 
“... desejo de tornar visível, o invisível, crença numa mudança política ao termo da morte ritual do indivíduo, obsessão pela participação do público no cerimonial cênico." ${ }^{n 0}$

Nesse sentido, nenhum outro encenador como llo Krugli propôs à criança a experiência do teatro em que lhe são dados os códigos, as chaves para a abertura das portas que levam à experiência da Arte.

No espetáculo As Quatro Chaves, as crianças são convidadas a buscar as chaves do baú onde foram aprisionados os desejos dos personagens: Joana quer filhos, o conhecido: uma conhecida, o gigante: um coração, Seu João quer pão para alimentar todos os filhos da Joana.

As crianças, todas juntas, mas podendo escolher os caminhos a seguir: terra, fogo, água e ar, ajudam a fazer de papel os filhos da Joana, fazem a massa do pão (que depois reaparece quentinho e é comido por todos), fazem o coração do gigante, e a conhecida do conhecido.

Enquanto fruidora da obra de Arte a criança é convidada a experienciar o teatro metaforicamente, esse teatro propõe valores, discute temas, abre lacunas a serem preenchidas com as reflexões e a imaginação da criança.

Nomear e qual nomenclatura usar para definir sua prática pedagógica vem exigindo reflexão. O grupo desenvolve uma prática voltada ao teatro, linguagem que se utiliza da música, das artes plásticas, da dança e da literatura e

\footnotetext{
${ }^{50}$ PAVIS, Patrice. Dicionário de Teatro. São Paulo: Ed. Perspectiva, 2000.
} 
tendo sido influenciado pelo pensamento de Herbert Read e da Escolinha de Arte do Brasil, o Ventoforte desenvolveu uma prática pedagógica que vem nomeando como educação pela arte ou arte-educação. A importância da nomenclatura está em contextualizar o grupo sem distanciá-lo das práticas contemporâneas em teatro-educação, uma vez que:

"Em nossos dias, a área de conhecimento que estabelece conexões entre os campos da arte teatral e da pedagogia é internacionalmente conhecido como Teatro-Educação." ${ }^{, 51}$

Sendo assim, abordaremos desse modo sua prática, embora no decorrer do texto as três formas tenham sido utilizadas: educação pela arte, arte-educação e teatro-educação, não por descuido, mas refletindo a pesquisa ainda imatura no nomear definitivo e principalmente em relação ao período histórico e político abordado.

Desenvolver a capacidade criadora da criança foi um dos ideais dos movimentos de caráter modernista, porém, a proposta em Arte-educação do grupo Ventoforte está longe de um deixar fazer livremente buscando só a espontaneidade, há uma elaboração das imagens, dos desenhos a partir dos materiais, da troca de experiências, das imagens sugeridas pelas letras das canções e toda a complexa rede de que se compõe o seu trabalho em que aula e espetáculos estão integrados.

A livre-expressão, o desenvolvimento da capacidade criadora da criança e os ideais do Movimento Escolinhas de Arte, são alguns dos temas da

\footnotetext{
${ }^{51}$ PUPO, Maria Lúcia B.S. Palavras em jogo. Textos literários e teatro-educação. Tese de livre docência. São Paulo, ECA/USP, 1997.
} 
dissertação de mestrado de Fernando Azevedo ${ }^{52}$. Nela o pesquisador inclui uma entrevista com llo Krugli. Faço aqui, uma breve síntese da pesquisa para discutir a visão modernista do ensino da Arte à qual llo Krugli é filiado pelo pesquisador.

A pesquisa procura esclarecer a transição do ensino de Arte desde o movimento das Escolinhas de Arte do Brasil (da livre-expressão, do deixar fazer, embutindo assim uma idéia de que arte não se ensina - uma visão chamada de modernista) até as recentes pesquisas que incluem leitura da obra de arte, fazer e contextualização, (Proposta Triangular, de que arte se ensina, se pesquisa - uma visão chamada de pós-modernista). Para aprofundar os temas, o pesquisador enfoca a experiência profissional de duas arte-educadoras, cada uma delas pertencente à um movimento ou tendo transcendido este movimento: Ana Mae Barbosa, difusora, no Brasil, da Proposta Triangular, na pós-modernidade e Noêmia Varela, no Modernismo.

"A idéia de livre-expressão, originada no expressionismo, levou à idéia de que Arte na educação tem como finalidade principal permitir que a criança expresse seus sentimentos e à idéia de que a Arte não é ensinada, mas expressada.

A Semana de Arte de 22 é considerada a primeira grande renovação metodológica no campo da Arte-Educação, os interesses pelas teorias expressionistas e pelas teorias freudianas irão levar a uma valorização da Arte Infantil. Segundo Ana Mae Barbosa, ${ }^{54}$ Mário de Andrade e Anita Malfatti foram os introdutores das idéias de livre-expressão para crianças no Brasil. Esses artistas

\footnotetext{
${ }^{52}$ AZEVEDO, Fernando Antonio G. de. Movimento das Escolinhas de Arte: em cena memórias de Noêmia Varella e Ana Mae Barbosa. São Paulo, Tese de Mestrado, ECA/USP, 2001.pág.70.

${ }^{53}$ BARBOSA, Ana Mae.Teoria e Prática da Educação Artística.São Paulo, Editora Cultrix,

${ }^{54}$ BARBOSA, Ana Mae. Teoria e Prática da Educação Artística. São Paulo, Editora Cultrix,
} 
foram influenciados por um movimento que aconteceu na Áustria; Franz Cizek é considerado o pai da livre-expressão por alguns teóricos. ${ }^{55}$

Nascido em 1865, Franz Cizek estudou na Academia de Artes de Viena, envolvendo-se com movimentos renovadores da arte, influenciados por tendências simbólicas e antirealistas do pintor Gustav Klimt, membro mais conhecido do grupo ao qual, o então estudante de Artes, Cizek, pertencia. Observando o trabalho de várias crianças, ele admirou-se com suas qualidades. Junto ao seu grupo ele foi encorajado a criar uma escola particular de Arte para crianças. Nascia assim, após algumas dificuldades, em 1897, a escola de artes para crianças de Cizek que, em 1904, foi incorporada à Academia de Artes e Ofícios de Viena, onde permaneceu até 1938, quando Cizek tinha 73 anos. Ele faleceu em $1946{ }^{56}$ Apesar de ser considerado o deflagrador da idéia da livre-expressão, o método proposto por Cizek, analisado por MacDonald, como registra Efland, ${ }^{57}$ não era exatamente o deixar fazer livremente. Trabalhos dos alunos demonstram uma sofisticação das formas, uma extrema competência e muito influenciado pela arte adulta. Contudo, o valor de Cizek e sua iniciativa não podem ser negados, liberdade pode ser considerado um termo relativo e para os padrões das escolas vienenses da época, sua pedagogia era, comparativamente, uma pedagogia livre.

Nas palavras de Fusari e Ferraz:

"A Educação Através da Arte, quando difundida no Brasil, recuperou a valorização da arte infantil e a concepção de arte baseada na expressão e na liberdade criadoras. Para que isso ocorresse era necessário a total independência

55 EFLAND, ARTHUR D. A History of Art Education.Intellectual and Social currents in Teaching the Visual Arts. New York, Teacher College Press, Columbia University, 1990.

56 Idem.pág 197.

57 Idem.Pág. 198. 
da criança ou do jovem, que deveriam produzir seus trabalhos artísticos sem intervenção dos adultos. Vale ressaltar, ainda, que desde os anos 20 alguns professores de Arte já vinham incorporando a idéia de livre-expressão entendida como um caminho para se atingir o centro de criação. Os primeiros trabalhos de Arte feitos pelo método da livre expressão foram os do educador tcheco Franz Cizek, da Escola de Artes e Ofícios de Viena, Áustria. Através de suas propostas Cizek demonstrou a importância estética e psicológica de libertar-se o impulso criador das crianças. O próprio John Dewey, depois de acompanhar as aulas do professor Cizek em Viena, manifesta o seu entusiasmo com relação a essa maneira de ensinar Arte escrevendo o artigo "Franz Cizek e o Método da Livre Expressão", que foi publicado no Journal of the Barnes Foundation, em outubro de 1925. ${ }^{.58}$

E os resultados específicos da Semana para a Arte-Educação, segundo Ana Mae Barbosa ${ }^{59}$, são a valorização do Desenho como técnica e a exaltação dos elementos internos expressivos como constituintes da própria forma. Somando-se os desdobramentos da Semana e novas propostas na área:

"Estava preparado o longo caminho percorrido desde as influências do liberalismo, procedentes do século XIX, até as primeiras manifestações da Arte Moderna, em 1922, para que no Brasil fosse possível, sobretudo após a Segunda Guerra Mundial, sob influência da Bauhaus, o desdobramento dialético das tensões entre Desenho como Arte e o Desenho como Técnica, entre a expressão do eu e a expressão dos materiais." 60

58 Citado por Thomas Munro, Art Education-lts Philosophy na Psychology, Nova York, The Liberal Arts Press, 1956. Apud FUSARI, Maria F.R. e FERRAZ, Maria Heloísa C. Arte na educação escolar. São Paulo, Cortez Editora, 1993.

${ }_{60}^{59}$ BARBOSA, Ana Mae. Arte-Educação no Brasil. São Paulo, Editora Perspectiva,1995.

60 Idem. Pág. 115. 
Os ideais da Semana permanecem, a idéia de revolução por vir, citando Chauí ${ }^{11}$ também se mantém, e assim teremos em 1945, uma floração, uma extensão da investigação estética proposta pelo movimento modernista, a geração de 45 , é a terceira geração modernista. Como representantes, na Literatura, cito João Cabral de Mello Neto, Clarice Lispector e Guimarães Rosa.

“(...) Contribuíram, sobretudo, para levar às últimas conseqüências certas tendências que vinham do modernismo dos anos 20, como a estética do fragmento, as intenções anti-líricas e um certo gosto pela desarticulação do poema. Com isto, instauraram um ar de jogo combinatório, de experiência calculada e de projeto mental, que contrastava com a expressão dominante de decênio de 50, a da chamada "geração de 45", formada por poetas inclinados ao mistério, ao sentimentalismo, a um certo patético, embora entre eles se inclua um completamente diferente, João Cabral de Mello Neto, precursor da vanguarda atual. ${ }^{, 62}$

Nesse panorama artístico surge, então, em 1948 no Rio de Janeiro, a Escolinha de Arte do Brasil, criada por Augusto Rodrigues, que iniciou a divulgação do movimento Educação pela Arte depois de manter contato com Herbert Read.

"O outro autor que vai assumir a base psicológica da pedagogia e influir no pensamento de professores de Arte é Herbert Read (1893-1968), filósofo inglês que se dedicou também à análise de expressões artísticas de crianças e adolescentes. Admirador de Carl Gustav Jung, médico e psicanalista alemão seu

\footnotetext{
${ }^{61}$ CHAUÍ, Marilena. Seminários. São Paulo, Editora Brasiliense, 1983, pág. 67.

${ }^{62}$ CANDIDO, Antonio. A Literatura em 1972. Arte em Revista $n \circ 1$, São Paulo, Kairós Livraria e Editora, Jan/Mar. 1979.
} 
contemporâneo, Read procurou demonstrar a presença dos arquétipos e símbolos na arte infantil por ele analisada." 63

As Escolinhas de Arte do Brasil se espalharam por vários estados do país, Paraguai e Argentina, e ainda hoje algumas delas estão funcionando, como a de Recife e a do Rio de Janeiro. A educação para a liberdade, juntamente com a proposta de Paulo Freire, irão se difundir. Entre as personalidades brasileiras que deram suas contribuições para elevar o nome da Escolinha de Arte do Brasil, podem ser citados Anísio Teixeira, Nise da Silveira, Oswald Goeldi, Abelardo Zaluar, Hidi Mignome.

A importância da escola e de sua proposta de ensino propagou-se de tal forma que chegou a receber até mesmo a visita do então presidente Juscelino Kubistchek. No folheto comemorativo de seus 53 anos, a Escolinha de Arte que ainda funciona no Rio de Janeiro salienta a visita do presidente para demonstrar sua importância e seu valor histórico.

Noêmia Varela define o movimento das Escolinhas como um "movimento de raízes subversivas, por isso mesmo, inerente à arte-educação, tão somente, na medida em que essa forma de educar exista no entrelaçamento do exercício do ato criador, tendo como suporte um discurso marcado por valores universais, vinculado à realidade educativa, na referência da realidade social sempre na dependência do espaço tempo do educando que nela está envolvido, a partir de seu próprio território existencial e em perspectiva de virtual construtor de outras formas inovadoras de educação." 64

\footnotetext{
${ }^{63}$ FUSARI, Maria F.R. e FERRAZ, Maria Heloísa C. Arte na educação escolar. São Paulo, Cortez Editora,1993.

${ }^{64}$ VARELA, Noêmia. Movimento Escolinhas de Arte. Revista Fazendo Artes n.o 13. 1988. pp2-7 in Jornal Arte\&Educação. Edição especial em comemoração dos 50 anos da Escolinha de Arte do Brasil. Fevereiro de 1999.
} 
Embora nascido de movimentos dos anos 70, o grupo vem construindo uma práxis política e estética que o insere na contemporaneidade e embora valorize a improvisação, esse não é um recurso exclusivo, incluindo o trabalho com textos dramáticos e de origem não dramatúrgica com o objetivo de nutrir 0 imaginário dos alunos.

"Se os anos 70 assistem à valorização absoluta da improvisação como recurso exclusivo em Teatro-educação, a década de 80 presencia uma nova tendência, sobretudo em determinados países desenvolvidos. A exemplo do movimento teatral mais amplo, no qual ganham relevo questões oriundas da encenação de diferentes modalidades textuais, as práticas em teatro-educação passam a incorporar o desafio do trabalho com textos considerados em suas múltiplas formas, dramatúrgicas ou não. Espera-se dele que possam nutrir 0 imaginário de quem joga."65

No decorrer deste trabalho foi incluída uma cronologia do grupo na qual se pode perceber que os textos montados são de origens distintas, sua prática pedagógica é sempre um comprometimento estético-político e os espetáculos são criados dessa mesma forma.

"Entre os traços mais marcantes desta concepção podemos destacar alguns: a busca de modalidades de representação que incorporem uma atuação marcada por algum tipo de organicidade, um alargamento da noção de teatralidade para além dos moldes consagrados, a abertura para a experiência por parte de quem atua, a valorização do trabalho coletivo, o questionamento dos

${ }^{65}$ Idem. 
papéis habituais de ator e platéia e a ênfase na reflexão sobre o próprio processo de criação."

A aprendizagem estética no Ventoforte inclui a intuição, forma de percepção pouco valorizada na educação ocidental e excluída do ensino formal. Para alcançar esta proposição de ensino da Arte da qual em sua entrevista llo Krugli fala despretenciosamente além do percurso histórico, da educação não formal, fora de instituições, realizada ao longo da vida me parece, que neto e bisneto de Javier de Villafañe como se define em seu poema, ele segue plantando plumas para que nasçam pássaros!!

Buscando chegar à essencialidade que só a poesia oferece e desistindo da moeda mais cobiçada, o reconhecimento. Tornar-se aprendiz de feiticeiro parece demasiado doloroso nos dias de hoje, mas insisto em continuar a desvendar os meandros da forma teatral engendrada por Krugli e o Ventorte no próximo capítulo.

${ }^{66}$ PUPO, Maria Lúcia S.B. Além das dicotomias. In. Anais do seminário nacional de arte e educação: Educação emancipatória e processos de inclusão sócio-cultural. Fundação Municipal de Artes de Montenegro, RS, Fundarte, 2001. 


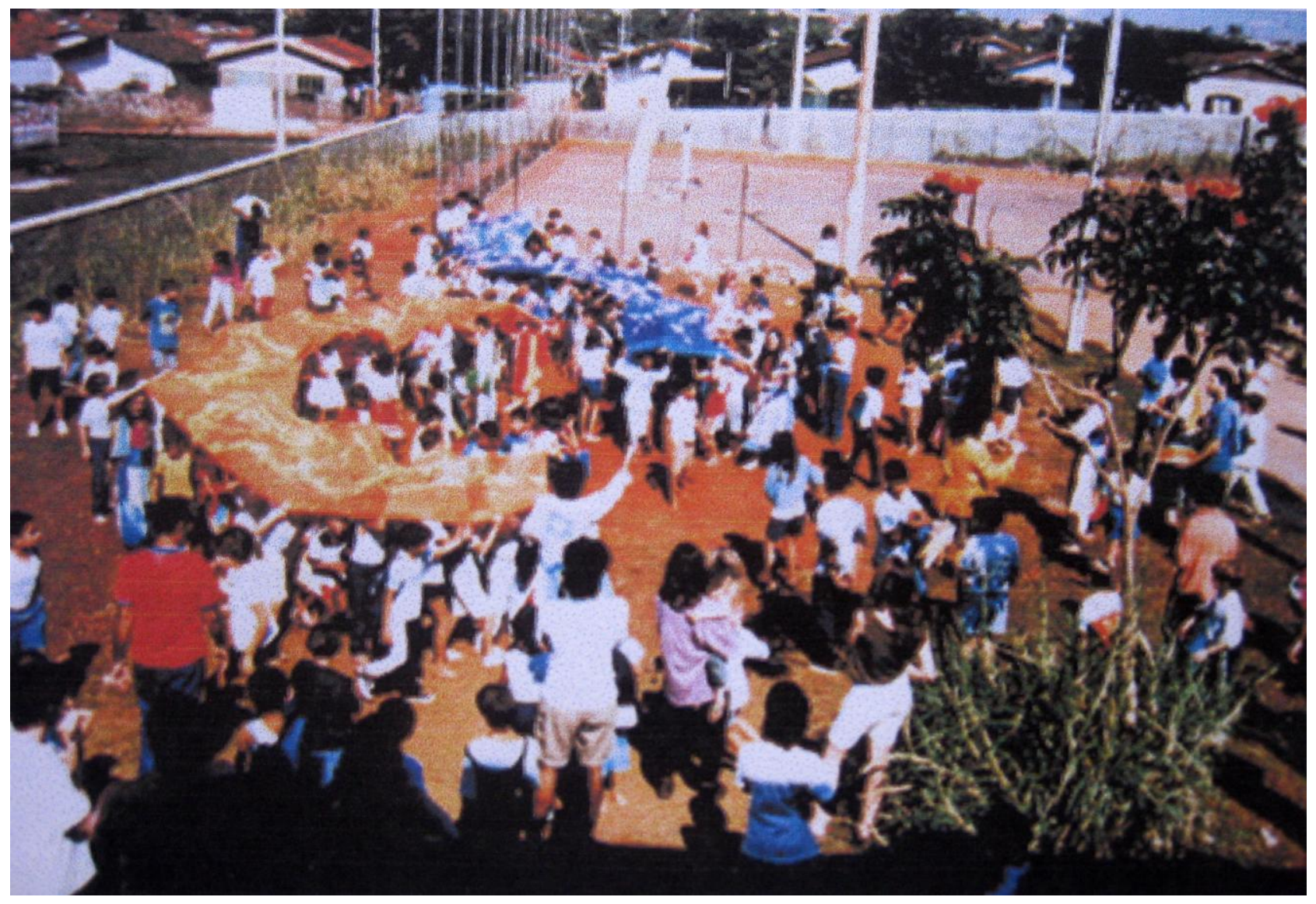

Foto As quatro chaves. Arquivo Ventoforte 


\section{Capítulo IV}

\section{A porta da Água e do Ar}

“(..) mas em estados de ânimo artísticos nós nos dirigimos a profundeza, onde nos enleamos por todos os lados com exclamações sintomáticas, sobre a vida e a morte, o bem e o mal, a substância, a beleza e outros tópicos inexistentes."

S. Langer

"Existo ou não existo?

Era uma vez uma rosa inexistente.

Ilo Krugli 


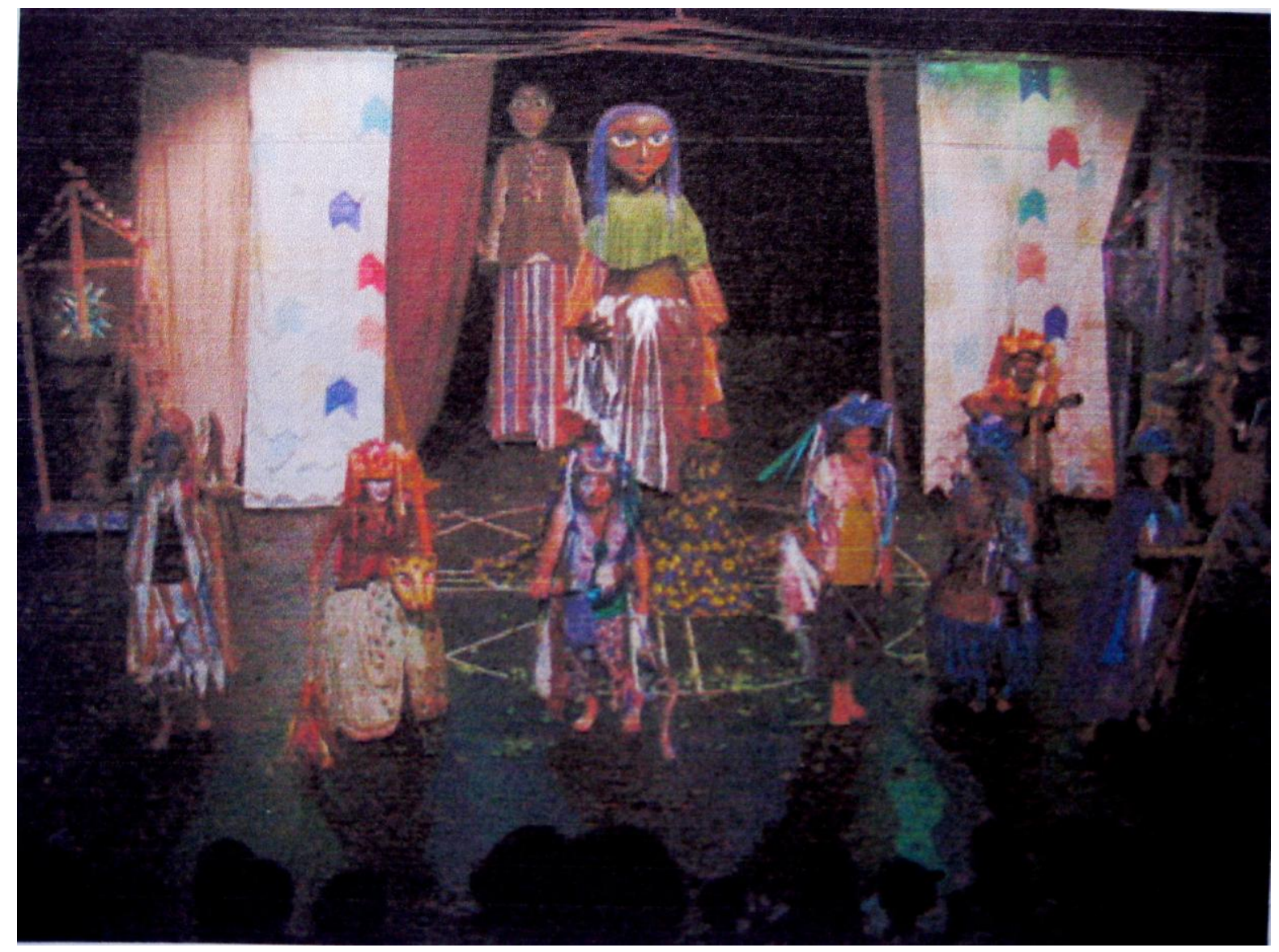

Mistério das Nove Luas. Foto: Fábio Viana. Arquivo Ventoforte 
As águas, aparentemente calmas e transparentes não sugerem a força que podem vir a adquirir; maremotos são alguns dos exemplos da devastação que podem provocar. Sem falar da escuridão e da profundidade. $\mathrm{O}$ ar, aparentemente inofensivo, transforma-se em brisa, vento, vendaval e este último pode destruir e carregar casas, até cidades. Assim, a passagem pelas portas da água e do ar imprimem, seja pela fluidez corredia, seja pela violência que podem vir a adquirir esses elementos, novas impressões no processo contínuo que deságua na elaboração de uma proposta de integração das Artes para uma integração do ser humano em um teatro construído por imagens de grande expressividade simbólica.

Essa forma teatral, manifestação estética não só voltada para a criança mas para pessoas de todas as idades possui especificidades, porém a universalidade das propostas codificadas em jogo simbólico fizeram por destinálas a um público mais amplo.

A linguagem do grupo trilhou uma interessante passagem: do teatro andarilho, teatro de bonecos, da festa de rua, identificando-se com presépios primitivos e representações de portais de igrejas, processos religiosos e profanos - o teatro ritual - às apresentações realizadas ao longo de temporadas em edifícios teatrais. Explorando outras modalidades de palcos traz a arte popular, o brinquedo vivo. $O$ auto popular é transposto para a cena.

Essa origem e a sua transposição têm grande peso no forjar das características da linguagem cênica do grupo no uso que faz da dramaturgia, do espaço cênico e do trabalho de ator. Grande parte dos textos encenados pelo grupo são adaptações e textos autorais de llo Krugli que lida com a dramaturgia da maneira mais ampla possível, multiplicando suas leituras; uma delas e 
constante na dramaturgia do grupo é o uso da forma épica, narrativa e do texto dramático conjuntamente fazendo do ator-manipulador, um contador de histórias.

"Ao contar os acontecimentos ao invés de mostrá-lo as personagens expõe os fatos em vez de dramatizá-los." 67

Algumas dessas características já foram inauguradas em Histórias de Lenços e Ventos. Um exemplo da complexidade dessa forma dramática é a cena do espetáculo em que se pode ver llo Krugli, em primeiro plano, com o personagem Jornal na mão; na sequência, ajoelhado junto a uma bacia ainda com o personagem Jornal, observa a água escorrer de uma lata cheia de furos levantada da bacia pela atriz, em segundo plano. O som da água caindo na bacia velha mescla-se aos sons produzidos pelos atores que ao fundo movimentam panos como em um vendaval. Enquanto isso o ator narra:

- As nuvens estão cobrindo o céu. Foi ficando escuro, escuro até que começou a chover... O Papel foi ficando molhado, quase se desmanchando. Se continuar chovendo, o nosso herói não vai conseguir salvar Azulzinha.

A atriz faz chover sem parar, entra a música e o Jornal está quase dentro da bacia. O ator manipulando o Jornal volta a narrar:

- E o Papel voou para outro quintal; nesse quintal encontrou outros personagens que estavam voando no céu sozinhos.

${ }^{67}$ ROSENFELD, Anatol. Teatro épico. São Paulo: $4^{3}$ Edição, Ed. Perspectiva, 2000. 
Na dramaturgia de llo Krugli, quando de seus próprios textos ( Histórias de Lenços e Ventos, A história do Barquinho, Da metade do caminho ao país do último círculo, Andando e voando com alguém e ninguém, Caminhadas, As quatro chaves e $\mathrm{O}$ mistério do fundo do pote) ou quando das adaptações, a forma narrativa está sempre presente. Em sua condução há uma procura pelo “(...) interesse apaixonado pelo desenrolar mais do que pelo desfecho. Cada cena é trabalhada isoladamente, o efeito de "montagem", o desenrolar sinuoso do enredo que se processa por "saltos" têm por objeto colocar o espectador "em face de algo" e fazê-lo reagir, mais do que deixá-lo a mercê dos sentimentos. "68

Pavis comenta que "o teatro épico tenta encontrar e acentuar a intervenção de um narrador, isto é, de um ponto de vista sobre a fábula e sobre a encenação."

No exemplo da bacia, a utilização da narração, aliando música composta para o espetáculo, a sons e imagens, torna o espectador observador da cena, despertando sua atividade, forçando-o a tomar decisões quando é colocado em face de algo. Esses são atributos do teatro épico, assim nomeado por B. Brecht na década de 20.

“(...) antes dele, Piscator deram este nome a uma prática e a um estilo de representação que ultrapassam a dramaturgia clássica "aristotélica", baseada na tensão dramática, no conflito, na progressão regular da ação. "70

\footnotetext{
${ }^{68}$ RYNGAERT, Jean-Pierre. Introdução à análise do teatro. São Paulo: Martins Fontes, 1995.pág.16

${ }^{69}$ PAVIS, Patrice. Dicionário de Teatro. São Paulo, Ed. Perspectiva,1999.

${ }^{70}$ Idem
} 


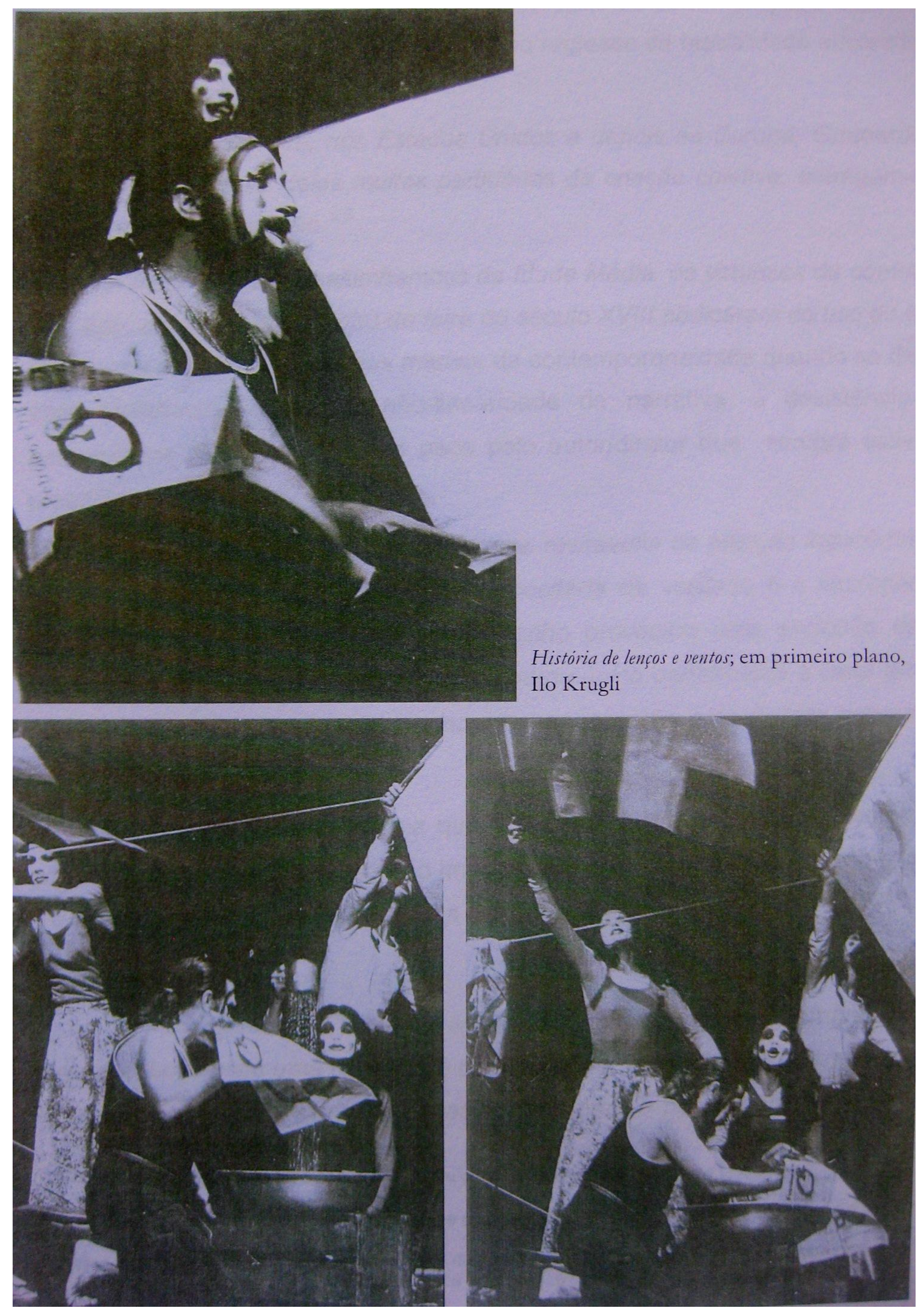


A encenação já esteve atrelada ao texto de tal forma que o espetáculo era definido por ele. Os anos 70 assistem ao regresso da teatralidade ancorada no corpo e na imaginação do ator.

"O Living Theatre, nos Estados Unidos e depois na Europa, Grotowski na Polônia, e na esteira deles muitos partidários da craição coletiva, entregam-se à vertigem da improvisação." 71

A festa antiga, os saltimbamcos da ldade Média, os virtuosoes da commedia dell' arte, os artesãos do teatro de feira do século XVIII abdicaram do uso do texto. E na sua evolução algumas das marcas da contemporaneidade quando se discute essa transformação são: a não linearidade da narrativa, a desistência dos personagens e a interrupção da peça pelo autor/diretor que sempre estiveram presentes na obra de Krugli.

"No final do séc. XIX tem início uma reviravolta da posição logocêntrica. A suspeita em relação à palavra como depositária da verdade e a liberação das forças inconscientes da imagem e do sonho provocam uma exclusão da arte teatral do domínio do verbo, considerado como único pertencente a cena e tudo o que se pode operar nela são promovidas ao escalão organizador supremo no sentido da representação."72

É Piragibe ${ }^{73}$ quem reafirma que a obra de Krugli é complexa em vista da profusão de referências e isso não impede que possua a clareza de comunicação e empatia direta com o público. E cita o próprio Krugli:

"A gente não faz uma linguagem para ser melhor compreendido. É claro que buscamos uma clareza de comunicação, mas não uma clareza racional. O que pretendemos é criar uma possibilidade para o público acolher o recado, a

\footnotetext{
${ }^{71}$ RYNGAERT,Jean-Pierre. Introdução à analise do teatro. Pág 27.

${ }^{72}$ PAVIS, Patrice. Dicionário de teatro. São Paulo, Ed. Perspectiva.

${ }^{73}$ PIRAGIBE, Mário. Um percurso do teatro de animação através da experiência de llo Krugli. Pesquisa para o site. (http://www.cbtij.org.br/pesquisa_p3.htm) pág 13.
} 
imagem ou a descrição de um conflito através de uma forma poética, menos ligada a uma concepção do real muito determinada. No teatro a, realidade e os conflitos do cotidiano aparecem através do jogo poético. Não é um jornal que informa, mas um espaço que enfoca os dramas do homem". ${ }^{74}$

Durante a pesquisa, Mário Piragibe ${ }^{75}$ situa o Ventoforte junto a grupos e encenadores contemporâneos como Eugênio Barba, autor dos livros: Canoa de Papel, Tratado de Antropologia Teatral, Além das Ilhas flutuantes, A arte secreta do ator, Dicionário de Antropologia Teatral, este conjuntamente com Nicola Savarese, fundador do ISTA (International School of Theatre Anthropology). E aos grupos franceses Velô Théatre, o Théatre cuisine, L'Arc-en-terre e o Teatro dellle Briciole, que investigam possibilidades de animação de formas, o chamado teatro de animação e teatro de bonecos.

Concordo que é uma maneira de tirá-lo do limbo ao qual vem sendo atirado por ter nascido e se influenciado pelos movimentos aos quais pode ser identificado e dos quais mantém características como por exemplo, a da catarse emocional, decorrência do período histórico em que elementos da linguagem do grupo se fundamentaram; por isso Fernando Azevedo afirma:

"A concepção de teatro de Krugli é de catarse emocional, concepção que está intimamente ligada ao ideário modernista de Arte/Educação" 76

\footnotetext{
${ }^{74}$ Idem, pág.15

${ }^{75}$ Idem pág 4.

${ }^{76}$ AZEVEDO, Fernando Antonio G. de. Movimento das Escolinhas de Arte: em cena memórias de Noêmia Varella e Ana Mae Barbosa. São Paulo, Tese de Mestrado, ECA/ USP, 2001. Pág. 71.
} 
Enfocando esse aspecto, o da catarse emocional, o pesquisador filia o teatro de Krugli ao ideário modernista, porém, esse é apenas um aspecto da concepção da linguagem do Ventoforte, se analisarmos o texto dramático, o espaço cênico e a animação de formas teremos que identificá-lo com diretores da pós-modernidade.

No uso do espaço cênico a transição ocorreu com a intenção deliberada de romper com o poder ilusionista do espetáculo. As propostas sempre levam em consideração o corpo no espaço, a palavra e o som em relação ao espaço, no qual tudo está à mostra, cortinas têm as roldanas aparentes, reguladores e bambolinas estão descartados, varas e urdimentos estão expostos ao olhar do público que acompanha a construção e desconstrução de cenários. Ribalta e gambiarras para a iluminação, tudo está à vista do público.

Atualmente, instalado num espaço arborizado, com vários barracões em torno de um coreto e fora do chamado circuito de teatros em São Paulo, o espaço do teatro de llo Krugli é contemporâneo ao de outros encenadores.

"Com Grotowski, Ronconi, Mnouchkine e muitos outros que lamentamos não poder enumerar aqui, o teatro liberta-se de suas amarras. O espaço teatral torna-se, ou volta a ser, uma estrutura completamente flexível e transformável (...) Agora o teatro pode ser feito em qualquer lugar- de preferência evitando-se aquelas construções a que se costuma dar o nome de teatros... A estrutura desse novo espaço pode variar ao infinito. Ela não conhece outros limites do que aqueles determinados pelo engenho dos cenógrafos, pela imaginação dos diretores, pela aparelhagem técnica e pelos materiais postos à sua disposição"77

\footnotetext{
${ }^{77}$ ROUBINE, Jean Jaques. A linguagem da encenação teatral. R.J, Jorge Zahar Editora, 1998. Pág.
} 85. 
A utilização dos planos que os barrações de seu teatro podem oferecer em alçapões alcançados por escadas mal encobertas por cortinas ou utilizando outros praticáveis que possibilitem à encenação maior mobilidade, faz algumas das encenações memoráveis na flexibilidade e transformabilidade das cenas que acontecem simultaneamente, cada plano compondo com a música as suas várias intenções. 


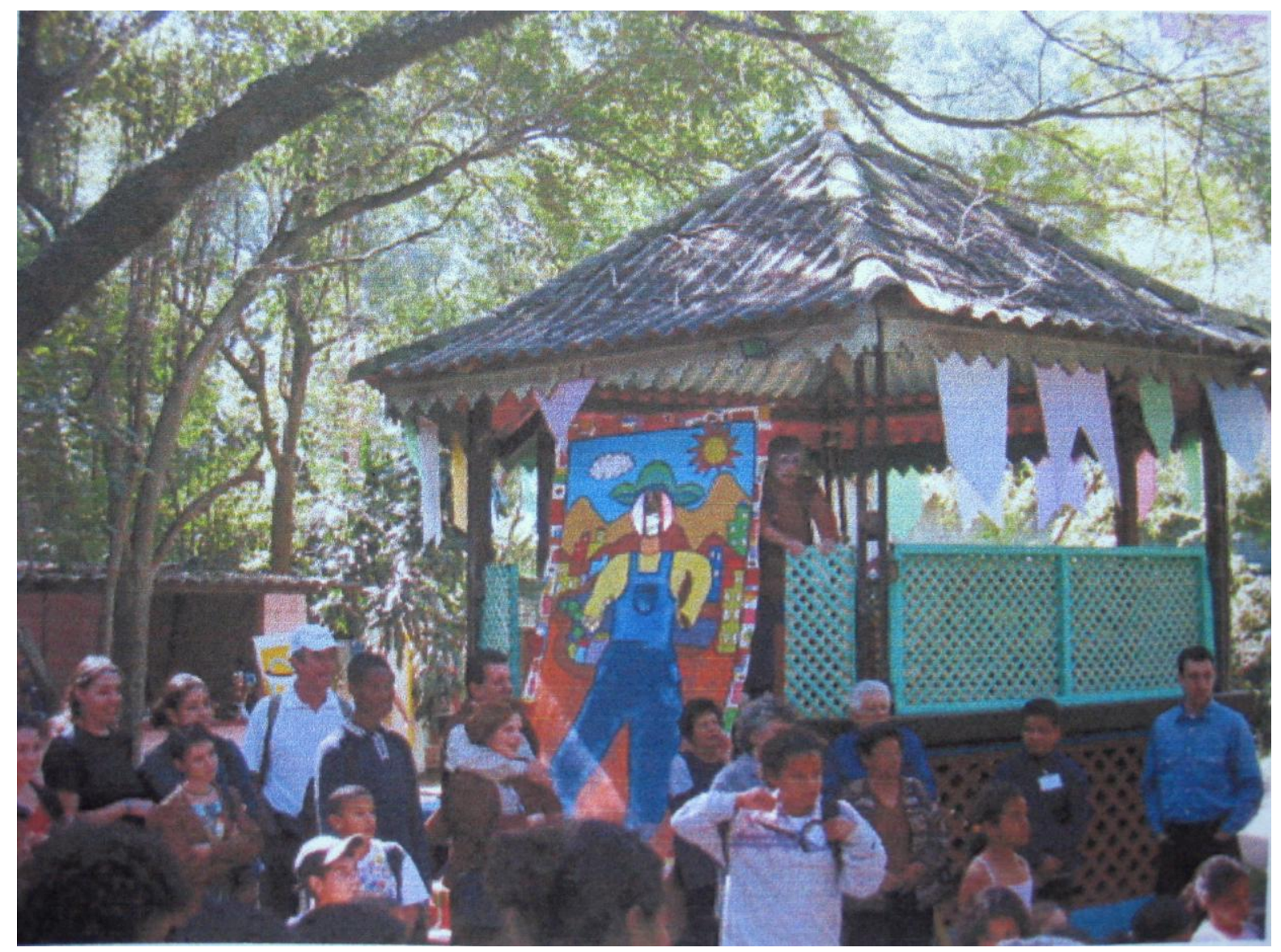

Espaço do Teatro Ventoforte. As quatro chaves. Foto: Fábio Viana. Arquivo Ventoforte. 
No próximo capítulo, a atriz Fátima Campidelli descreve sua criação para a personagem Ariel do espetáculo "A Tempestade". Com muita leveza Ariel, um espírito a serviço de Próspero, desaparecia e voltava a aparecer em locais diferentes do espaço cênico enquanto as cenas se desenrolavam. Isso em um teatro rústico, feito com panos e objetos, sem aparelhagens e exigindo uma grande preparação corporal do ator.

Também em "Minueto para o final do século" atuando com a bailarina Mariana Muniz e cinco músicos, llo Krugli em meio à escadas e velas que se transformavam em espaços os mais variados e dos quais a bailarina pode tirar grande proveito cênico fazendo com que em meio à cortinas surgissem os diferentes personagens presentes na história.

Caracterizada pelo excesso de imagens, e buscando símbolos para expressar o imaginário coletivo do grupo, o que para mim não quer dizer, então, conhecendo-se o "valor" que tem tido a imaginação no mundo ocidental e considerando ao que nos referimos quando falamos em imagem e imaginário que o teatro feito pelo grupo deseja refletir mitologias ou sugerir visualmente 0 arquétipo como afirma Silvia Fernandes.

"No Ventoforte, a pesquisa teatral é uma busca de religação com as raízes primitivas do homem. As imagens da cena, mais poéticas que dramáticas ou narrativas, são a forma encontrada pelo grupo para sugerir visualmente $o$

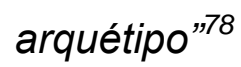

E ainda,

78 FERNANDES, SILVIA. Grupos Teatrais. Anos 70. Editora da Unicamp, Campinas, 2000. Pág 15. 
“... descobrindo uma forma particular de fazer teatro à medida que faz teatro, no que é acompanhado pelo Ventoforte, que estrutura uma linguagem a partir de experiências destinadas em última instância, a responder ao desejo de transmitir uma mitologia do inconsciente"79

A idéia de arquétipo vem da psicologia analítica proposta por C. G. Jung. Contudo, foi nos movimentos resistentes e guardiães do imaginário enquanto reinava o cientificismo racionalista - o romantismo, o simbolismo e o surrealismo -, que o sonho, o onírico e até mesmo a alucinação tiveram uma reavaliação positiva. Como resultado tivemos a "descoberta do inconsciente", título dado por Henri Ellembergr. ${ }^{80}$

Essa descoberta relaciona-se a Freud e à psicanálise comprovando o papel decisivo das imagens como mensagens que afloram do fundo do inconsciente do psiquismo recalcado para o consciente. Carl Gustav Jung, discípulo de Freud é quem vai trazer a idéia de que a imagem é um modelo de autoconstrução (ou individuação) da psique. Assim a imagem passa de papel de sintoma ao de agente terapêutico, como propôs aqui no Brasil a médica Nise da Silveira e que desenvolveu estudos junto à Escolinha de Arte do Brasil e viria a influenciar artistas e professores no que tange ao pensar a imagem e a criação.

Em síntese, a imagem, a poética são elementos que compõem o imaginário. Identificar um teatro da imaginação diretamente e apenas a arquétipos limita a rede complexa de que é feito o teatro do grupo Ventoforte.

79 Idem. Pág. 219.

80 DURAND, Gilbert. O imaginário. Ensaio acerca das ciências e da filosofia da imagem.2ํedição, Rio de Janeiro, Editora Difel, 2001. pág 35 


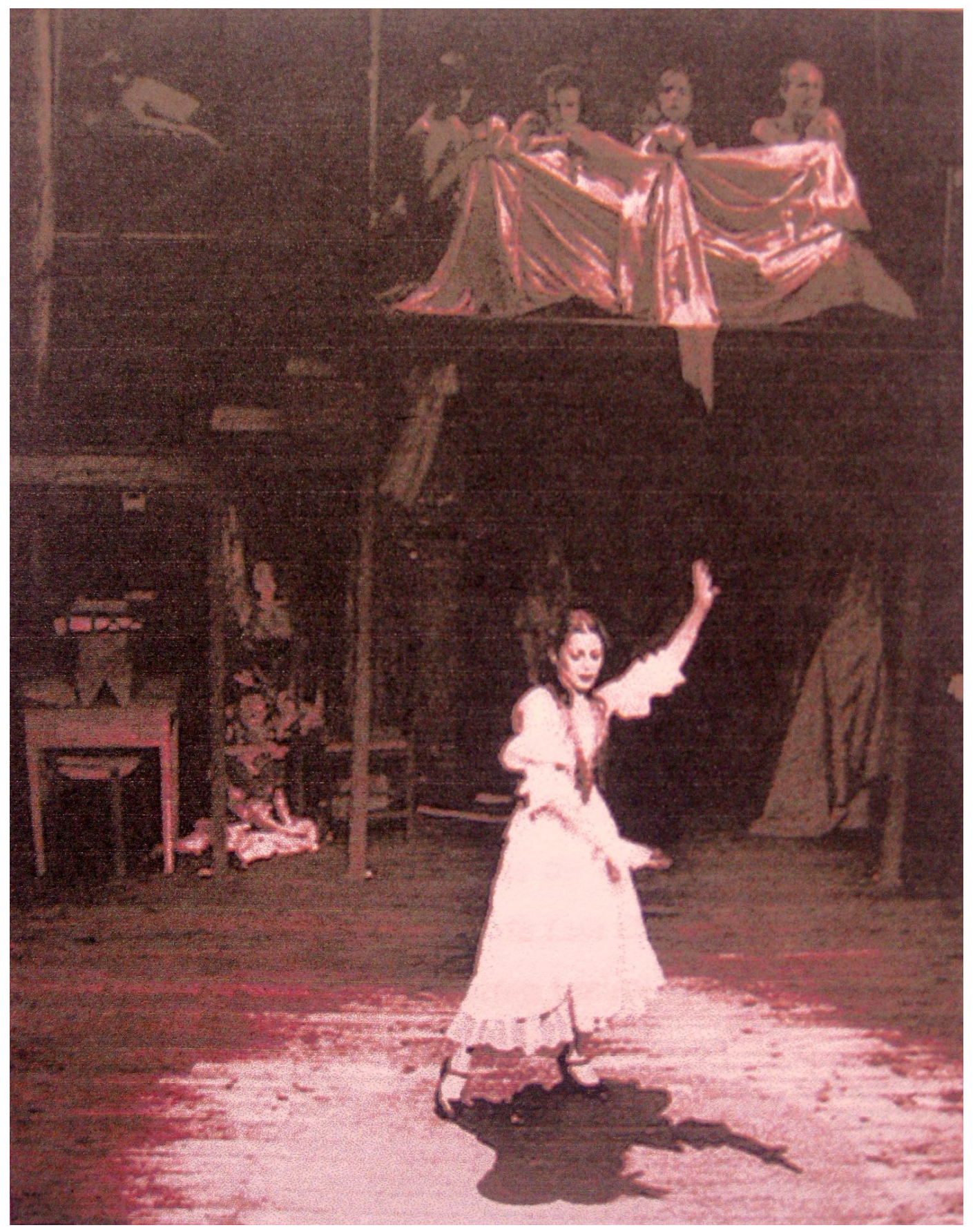

Espetáculo: Choro Lorca. Foto: Gil Grossi. Arquivo Ventoforte. 
Esse é o pensamento de llo Krugli. Em entrevista de 1993 ele afirma que:

“(...) a influência do inconsciente eu não diria, sem inconsciente não se pode criar, não é não, não fomos nós que inventamos, nem a Nise da Silveira, ele é uma coisa viva, real, inteira, o ocidente divide muito consciente de inconsciente. Nem sempre o inconsciente está falando uma coisa e o inconsciente outra ao mesmo tempo, são formas convencionadas de se falar alguma coisa em algum plano do ser humano, o plano não só das relações de comportamento mas das comunicações transcendentes. Está presente no trabalho que fazemos, a Nise é uma influência na minha vida porque é uma pessoa com a qual eu lidei bastante, este é o mesmo caminho porque ela foi estudou, trabalhou mas não é também uma coisa assim de profissão de fé, nós somos junguianos, nos somos...é porque são, porque isso às vezes se confunde...agora somos, como se fosse....e aí está falando meio em uma moda. Agora somos budistas, mudou totalmente a religião, eu acho meio difícil mudar a religião totalmente porque existe um processo interno que vem de ancestralidades, pode ter identificações. ${ }^{81}$

O clima visual cigano, a Andaluzia são referências estéticas no teatro de Krugli, mesclados a outros elementos configurando sua estética rústica, temos os espetáculos As Pequenas Histórias de Lorca de (1976), Choro Lorca (1986), Sete-corações (1986), Tragicomédia da Lua Branca (1995) nos quais a poesia e a dramaturgia de Lorca assumem a forma teatral de auto popular.

\footnotetext{
${ }^{81}$ CAVINATO, Andrea. Ventoforte: de "Histórias de Lenços e Ventos ao Príncipe feliz, sua trajetória de construção de uma linguagem teatral. Entrevista de llo Krugli concedida em 1993. Monografia de conclusão de curso, Faculdade de Medicina, T.O/USP, São Paulo, 1994.
} 


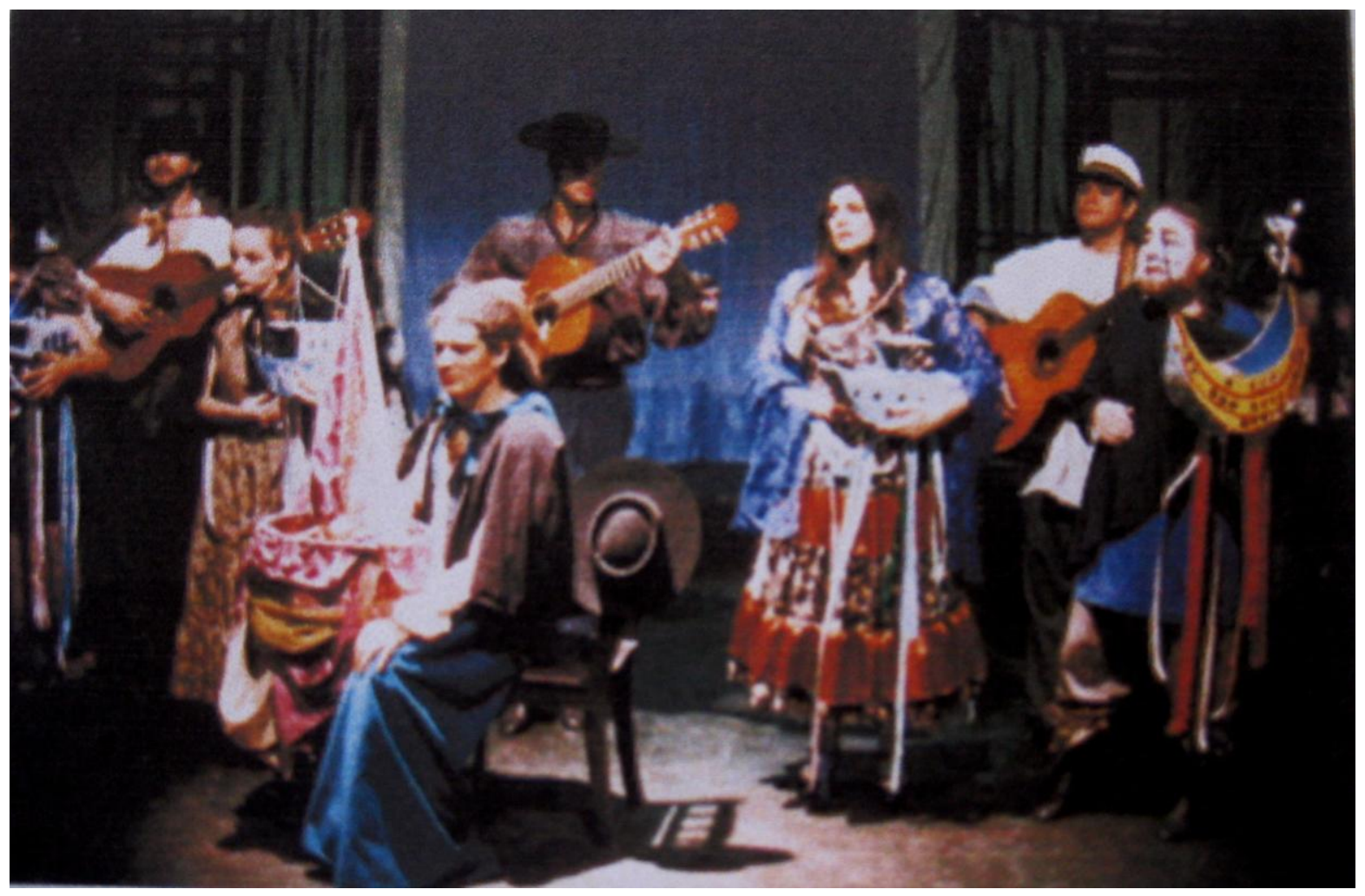

Tragicomédia da Lua Branca. Foto Gil Grossi. Arquivo Ventoforte. 


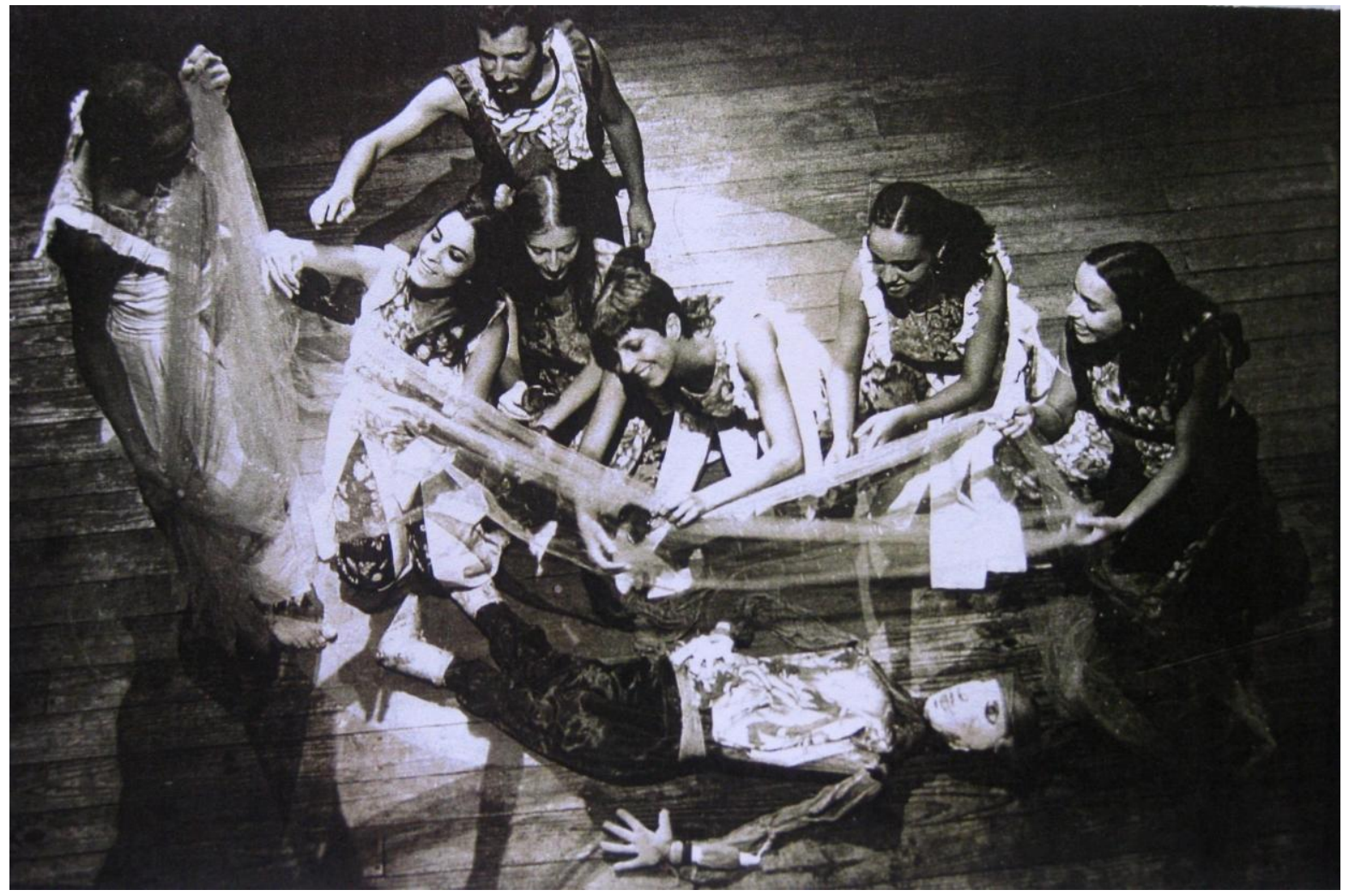

Qualquer homem é suspeito. Foto Valdir Silva. Arquivo Rosa Comporte. 


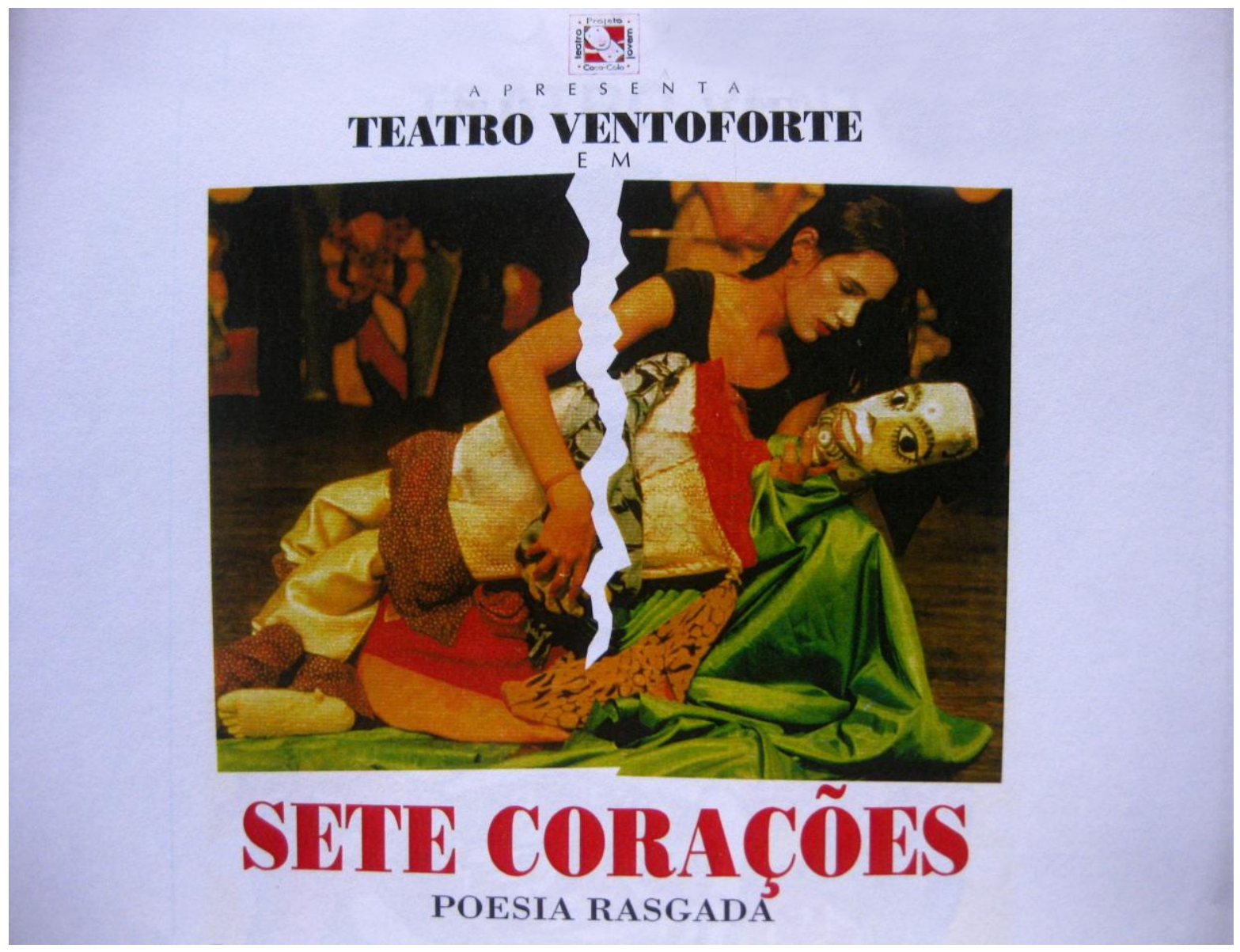

Programa Sete-corações. Poesia Rasgada. Arquivo Andrea Cavinato. 
de Federico Garcia Lorca
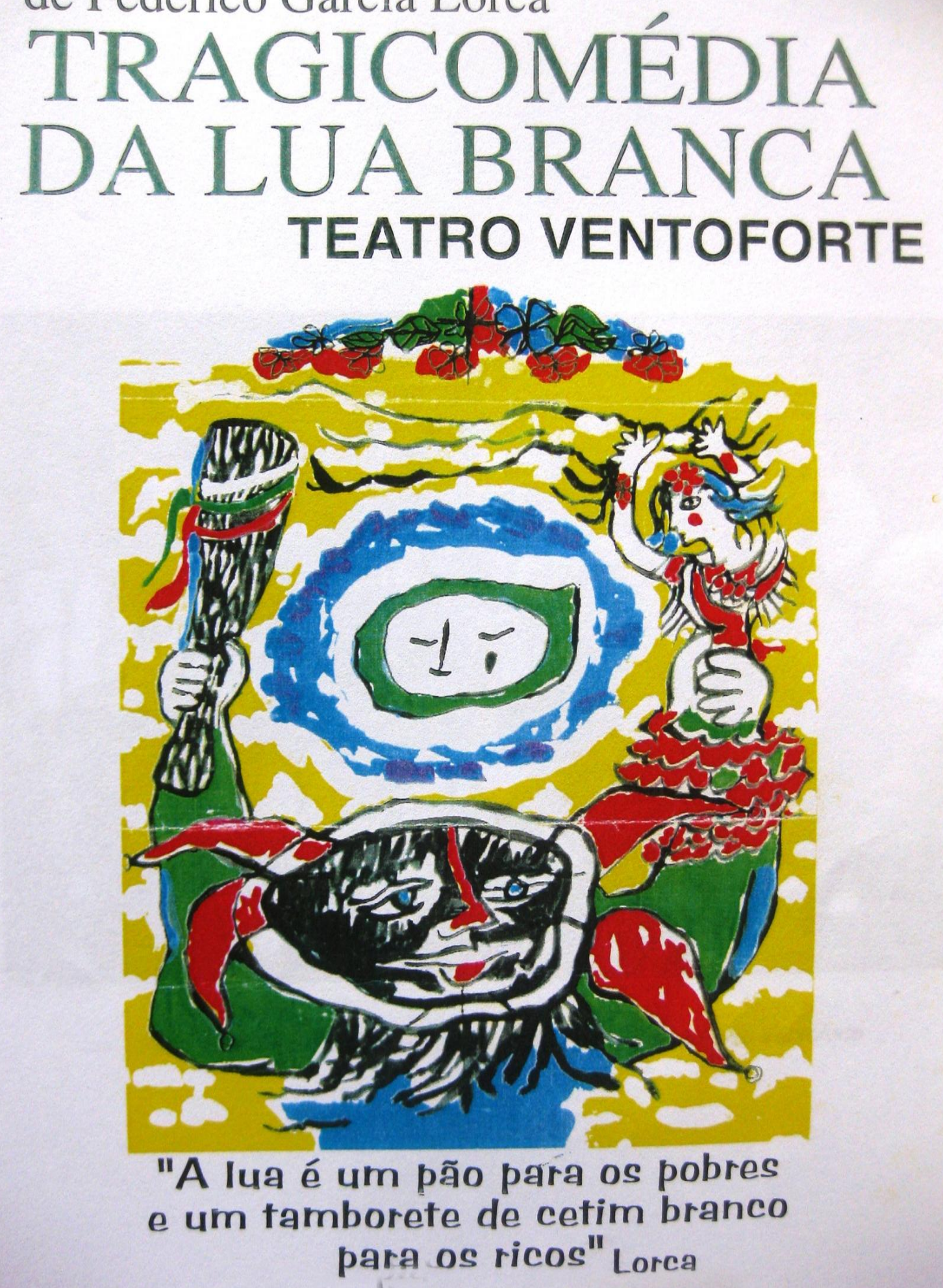

Cartaz Tragicomédia da Lua Branca. Arquivo Andrea Cavinato 


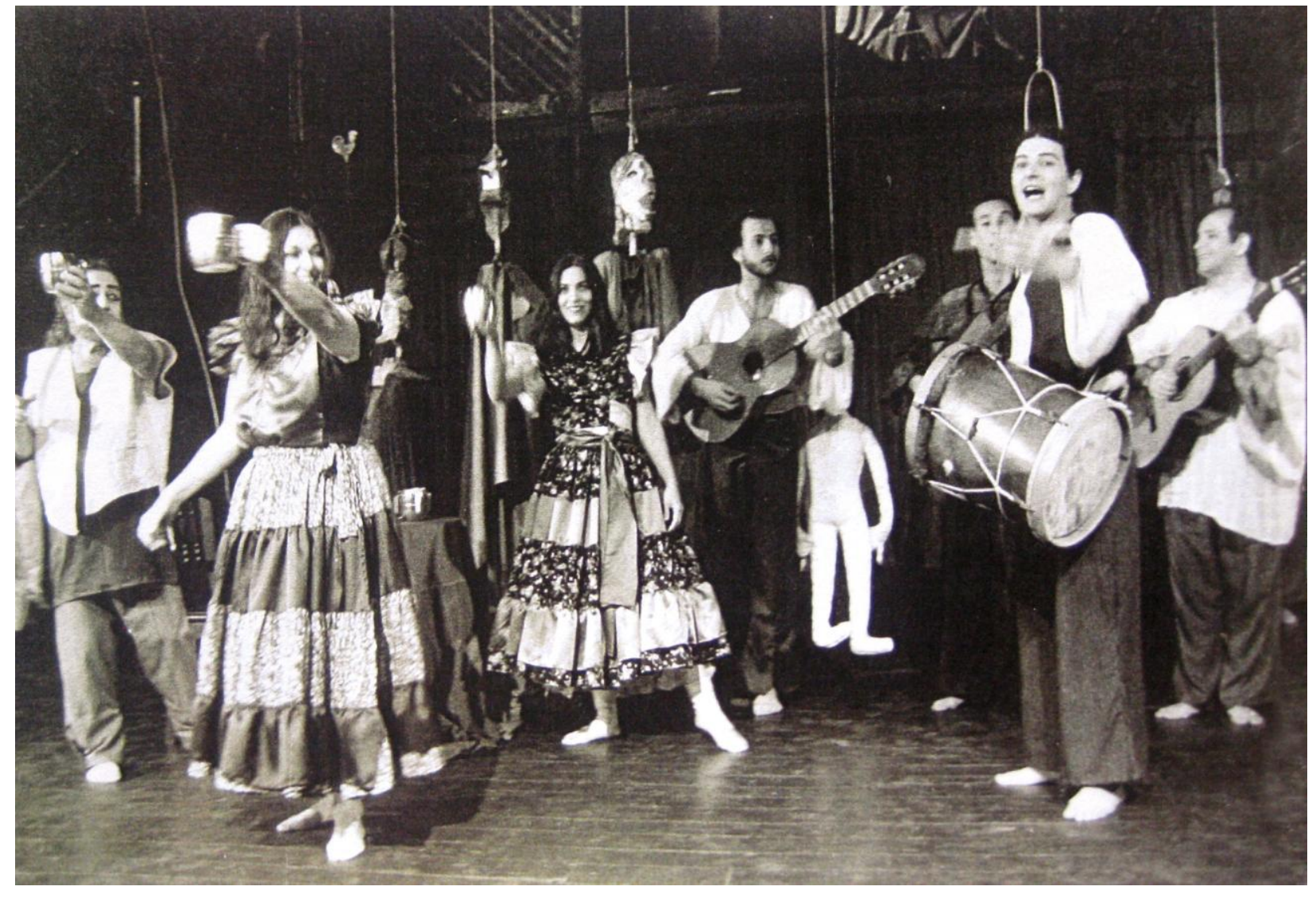

Foto Tragicomédia da Lua Branca. Foto Gil Grossi. Arquivo Ventoforte 


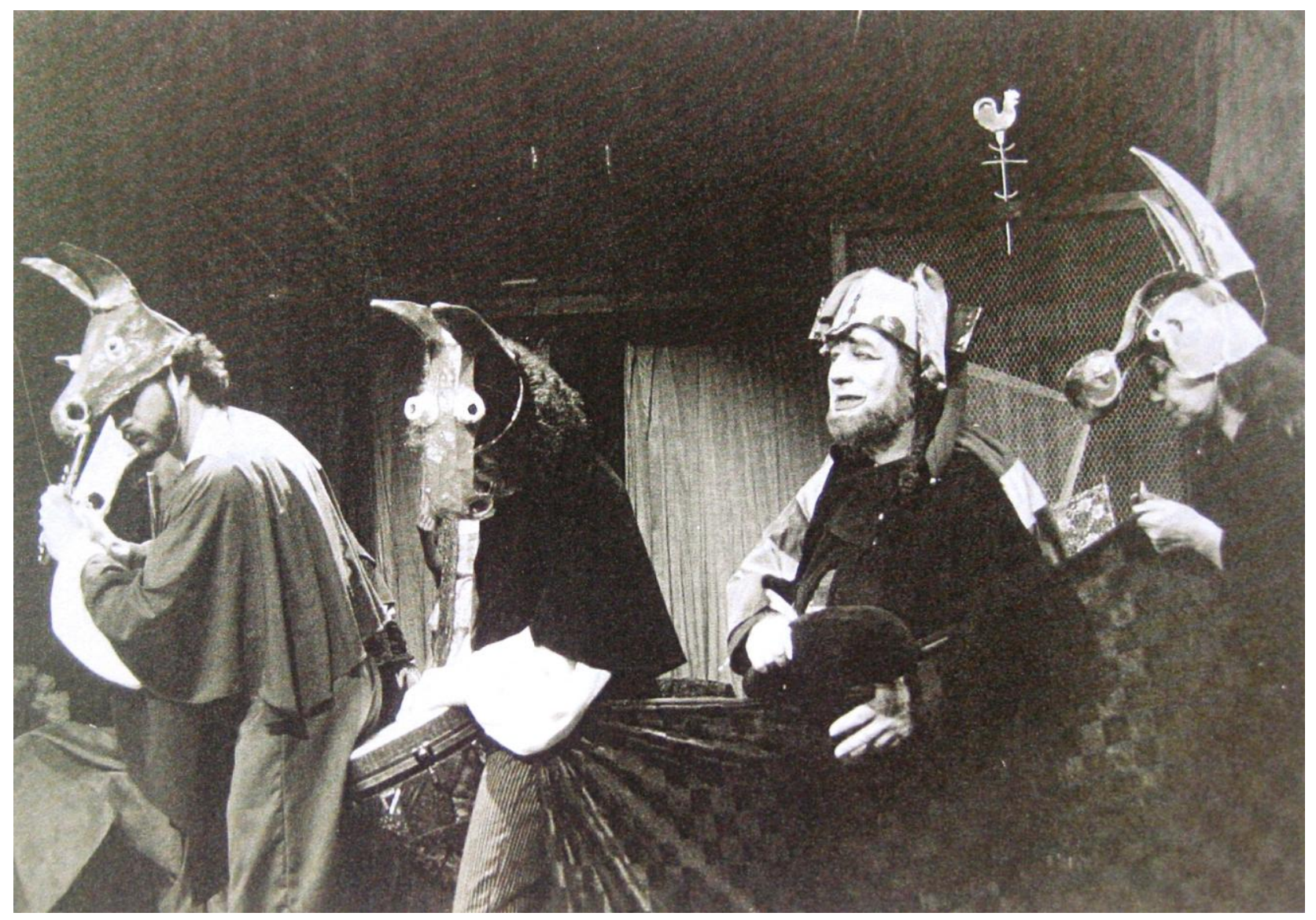

Foto Tragicomédia da Lua Branca. Foto Gil Grossi. Arquivo Gil Grossi 


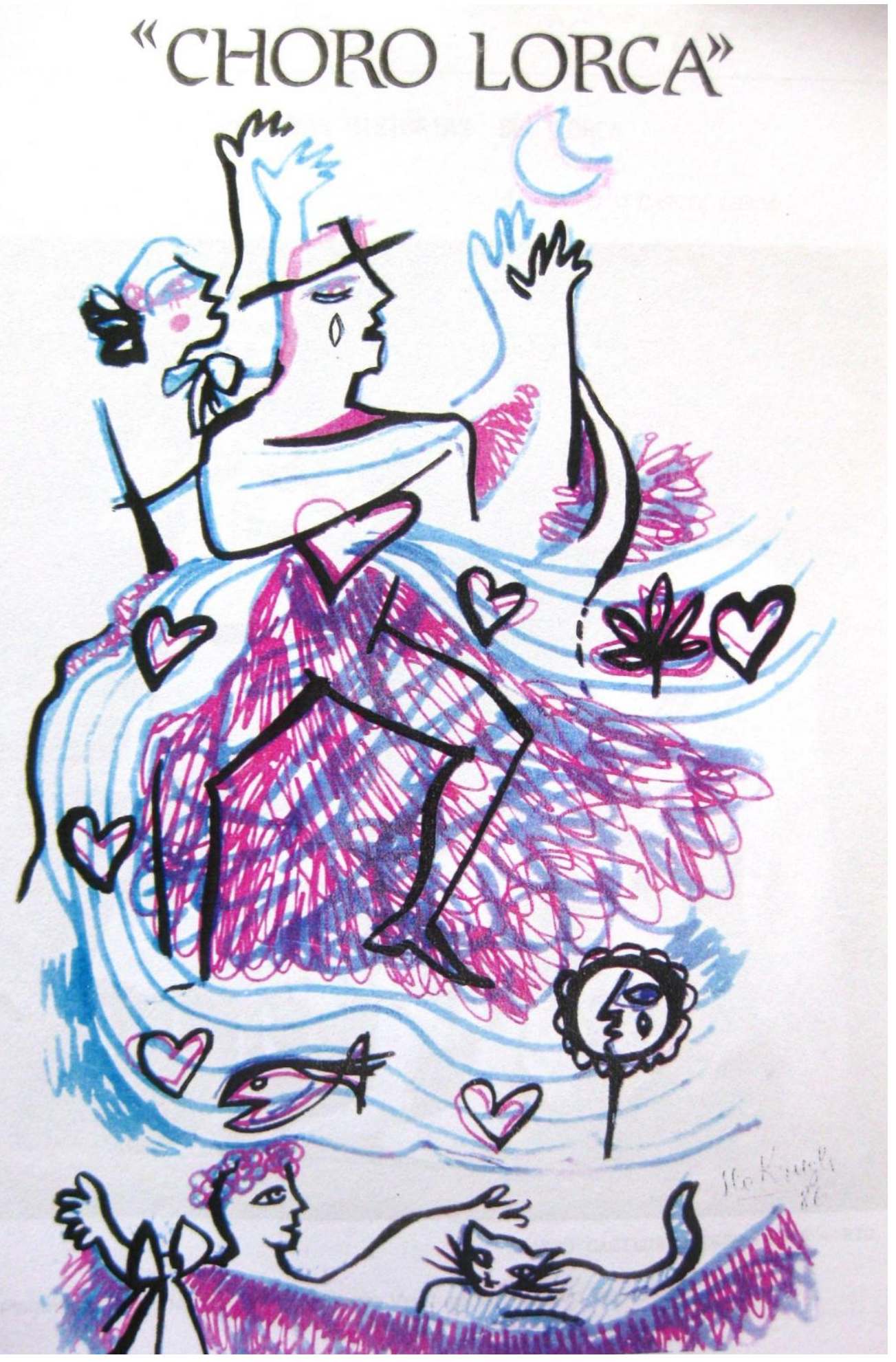

Capa do programa do espetáculo Choro Lorca. Arquivo Andrea Cavinato. 


\section{PEQUENAS HISTÓRIAS DE LORCA}

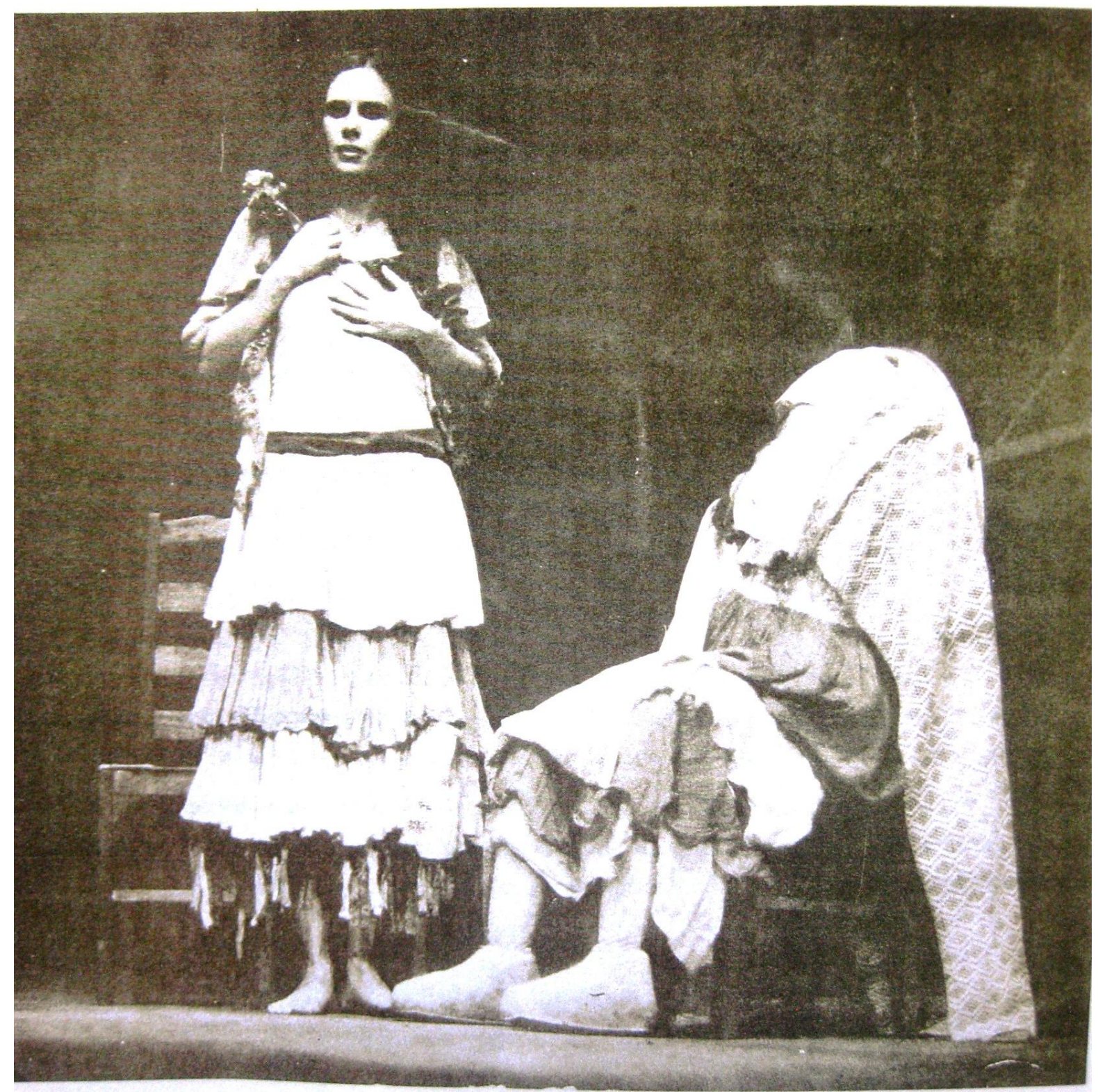

TEATRO CACILDA BECKER - 1976 - RIO

Pequenas Histórias de Lorca. Folheto Ventoforte. Arquivo Ventoforte 


\section{O Ventoforte faz de você um herói}

"A memória e o esquecimento são igualmente inventivos"

J. L. Borges

O grupo Ventoforte manteve ao longo do tempo cursos de formação de atores que em alguns casos passavam a atuar e a dar aulas no próprio grupo. Os misteriosos pássaros de barro, Brinquedos da Noite, Luzes e Sombras, Os cisnes selvagens, Dois irmãos, Uma rosa para Bela e Histórias que o Eco Canta são os espetáculos gerados nos cursos e dirigidos tanto por outros professores como por llo Krugli que coordenava a equipe. Os cursos cumpriam dupla função: renovavam o elenco, forneciam vasto material criativo que se transformavam em espetáculos, festas e pequenas apresentações e a manutenção material do grupo e do espaço.

O processo de ensino-aprendizagem do qual enquanto aluna-atriz participei na íntegra originou o espetáculo Histórias que o Eco canta que estreou em 1995. A partir de anotações de uma espécie de diário de bordo e o recurso da memória quero descrever e demonstrar o processo de construção sensível da aquisição da linguagem teatral proposto por llo Krugli. Processo que integrou todas as etapas de construção de um espetáculo teatral: a participação nos ensaios, na produção, na divulgação, na construção dos cenários e dos adereços.

Os textos escolhidos e trabalhados foram contos de Oscar Wilde (1854-1900). A escolha dos textos de origem não dramatúrgica para o desenvolvimento das propostas de montagens com os alunos é uma constante no grupo. Em outros tempos a escola era mais conhecida por formar atores para o teatro infantil, mas à medida que o público se definiu - para todas as idades também a formação ganhou um outro status, uma vez que é conhecido o 
preconceito em relação aos profissionais de teatro infantil essa mudança também ocorreu devido à conscientização e amadurecimento da proposta. A escolha desse tipo de texto claramente possibilita a riqueza de imagens, valores e símbolos coerentes com a visão de mundo do grupo e de ensino da arte e a possibilidade de a partir dela exercitar uma dramaturgia própria.

A escolha recaiu sobre os contos: $O$ amigo dedicado, $O$ rouxinol e a rosa, $O$ gigante egoísta, $O$ aniversário da infanta, $O$ filho da estrela, $O$ foguete ${ }^{82}$. A escolha e sugestão dos contos partiu do coordenador e professor do curso, llo Krugli, que já havia montado um conto do autor, O príncipe feliz, seu brinquedo desde a infância.

Sua preferência pelos contos desse autor é por estes conterem temáticas que têm identidade com as propostas do grupo. Os contos foram escritos por Wilde para seus filhos em 1888 e embora reunidos por uma editora com o título de histórias de fadas, são contos de autor e refletem a visão que Wilde tem da sociedade, seu modo de ver o mundo. Realidades muito duras, tristeza, morbidez, um retrato de uma sociedade fútil, desigual e opressora, amores impossíveis, com questionamentos profundos sobre a existência e seus valores morais.

A escolha do autor e de seus contos para crianças de todas as idades, coerente com a afirmação do grupo, de que faz teatro para todas as idades, pois aborda temas universais, gerou pesquisa e discussão e possibilitou a compreensão da visão que o grupo tem da criança.

${ }^{82}$ WILDE, Oscar. Histórias de Fadas. Rio de Janeiro, Ed. Nova Fronteira, 1992. 
A criança é vista como ser simbólico capaz da compreensão complexa da narrativa se esta preservar e respeitar elementos que são inerentes à criança enquanto sujeito que está se construindo no mundo.

Desde os anos 70 o Ventoforte contraria valores estereotipados da sociedade como o de que criança gosta de coisas alegres, ou de que a produção precisa ser de fácil compreensão e linear. Muitas vezes o teatro infantil produz discursos moralizantes em que a participação da criança é a mesma dos programas de auditório. Os contos de Wilde com personagens próximos às crianças: anões, princesas, pássaros, gigantes e flores, estão possibilitando diferentes formas de se ver o mundo. Este fato, associado à eficiência da encenação, originaram um espetáculo singular.

\section{O autor}

Oscar Wilde, irlandês, autor dentre outras peças, de Salomé, O marido ideal e A importância de ser prudente, teve sua opção sexual conhecida no mundo todo por ter sido acusado e preso por assédio a um jovem lorde. Visto como decadente e degenerado pela sociedade e pela imprensa londrina do século XIX, foi considerado por artistas e intelectuais pela sua contribuição ao teatro e à arte de pensar e filosofar com inteligência e sensibilidade.

\section{O processo e o produto}

A ordem em que vou apresentá-los é a da minha lembrança em um sentido ao mesmo tempo racional e emocional, que é a lógica da memória.

- Leitura em grupos. A partir da leitura, uma caixa de papelão deveria ser transformada no espaço que o conto sugeria, incluindo clima, cores, e outros 
elementos que o grupo pudesse perceber. Esse trabalho originou, por exemplo, um livro grande, em papelão pintado aberto na página onde se via um grande castelo também de papelão, referindo-se ao Aniversário da Infanta, quatro caixas em que se viam pintadas uma floresta, cada caixa uma estação do ano, para $O$ gigante egoísta, um imenso jardim de papel crepom com roseiras feitas de galhos secos e rosas de crepom e uma casa pintada e recortada em papelão para $O$ rouxinol e a rosa.

- Utilizando as caixas contar em grupo a história para ou outros participantes procurando apenas ater-se ao início, ao meio e ao fim da história. Desenhos das etapas, do que foi contado e das personagens.

- Escolha de um trecho do texto para ser transformado em objeto.

- Trocar as histórias e contá-las com outros objetos. Foram utilizadas pedras, caldeirões, bacias, tambores, desenhos, dentre outros.

- A partir da escolha de um dos personagens de qualquer um dos textos buscar imagens para essa personagem através do exercício dos sete corações, buscar imagens que representem corações para a personagem, entendendo coração como o impulsionador da vida.

- Escolha de quatro movimentos e fragmentos da história para cada um deles.

- Exercícios da palavra no espaço, gesto e texto no espaço modulando a forma, a intensidade e o volume. 
- As caixas (cenários) eram dispostas pelo teatro como o canto de cada conto, a proposta: contar partes, trechos, fragmentos da história à medida que se passasse pelo canto, enquanto se brincava de roda, ou se trabalhava. O exercício de trabalhar: gestos referentes a um trabalho da história eram escolhidos, tinham de ser artesanais, não podia ser o do rei, o objetivo é para inspirar o gesto, e o trabalho do rei é reinar; os trabalhos variavam, os gestos surgidos por exemplo foram cozinhar, bordar, fiar, costurar, cavar, carregar carrinho de mão, plantar, carregar água, lavar roupa, dançar. Só se podia parar de trabalhar para contar a história, no canto dela.

- Escrita de texto. Cada participante (o grupo diminuiu bastante no decorrer do processo) deveria escrever um texto relacionado à história que vem contando com objetos e a da personagem.

- Discussão dos textos juntamente com as histórias referentes à dos integrantes que permaneceram no grupo até essa fase. Os textos que se mantinham eram $O$ aniversário da Infanta, $O$ gigante egoísta, o amigo dedicado e $\mathrm{O}$ rouxinol e a rosa. $\mathrm{Na}$ discussão optou-se por suprimir partes desses textos escritos que não tivessem realmente sido improvisadas e contadas nas aulas. $\mathrm{Na}$ última fase a história $O$ amigo dedicado foi deixada de lado, a representante da caixa abandonou o grupo durante a composição de seu texto.

- Sistematização do texto. Em 1995, no segundo ano de trabalho llo Krugli escreveu o texto do espetáculo a partir dos textos entregues pelos alunos, uma espécie de colagem à medida que adaptava os contos.

- Trabalho com o texto final. Leitura no início dos ensaios e improvisação de várias formas, corporalmente, com objetos, com palavras, com bonecos, sem 
palavras, a regra é permanecer fiéis ao novo texto e trabalhar com trechos memorizados na leitura.

A partir dessa etapa uma grande ênfase será dada à palavra, as imagens que as palavras traduzem. Os jogos são brincadeiras de roda cantadas, e escravos de jó com os bonecos que acabaram por permanecer no espetáculo.

- Continuidade da experimentação. Dizer os textos de formas variadas, as propostas eram dizer como quem está gripado, ou dizer, com muita raiva, sussurrando, etc.

O texto não foi escrito cena a cena como a seqüência de sua forma final, foi rearranjado muitas vezes, a narrativa não foi colocada de forma linear. Essa idéia também permaneceu no trabalho, assim como nossos exercícios vocais de chamar de longe e de perto.

- A música. Durante as aulas/ensaios, professores- músicos criaram músicas e llo escreveu canções para o trabalho. Piano, violão, flauta, e outros instrumentos de sopro, percussão e voz.

- Material cênico, adereços e cenários foram compostos pelos alunos no decorrer do processo.

- Figurino. Os ensaios foram feitos com nossas roupas de aula e outras para compor as personagens trazidas pelos alunos que eram sobrepostas, foram feitos desenhos com idéias de cores e esboços para o figurino, llo Krugli sistematizou essas idéias e a idéia de sobreposição foi mantida. 
- Luz. Executada por alunos e criada em parceria com os professores.

O espetáculo como um todo eram recortes das aulas e das improvisações rearranjados por llo. Para alinhavar os contos ele propôs algumas cenas prontas, o resultado final era o de jogo, o grupo passara quase dois anos jogando juntos, o uso constante dos bonecos e dos objetos também compunha o clima de jogo. $O$ espaço sugeriu um sótão, um quintal atemporal.

Nenhum dos atores decorou seu texto que foi sendo aprendido no decorrer do processo. Anos depois o texto final, um roteiro, quase sem rubricas foi organizado. As histórias contadas foram O Aniversário da Infanta, O Rouxinol e a rosa e O gigante egoísta.

O teatro de imagens, de festa de feira foi uma opção do grupo presente também em Histórias que o Eco canta. As cenas formavam quadros, pinturas que se sucediam em espiral, simbolizando em conjunto com a música o tempo e o conhecimento. Enquanto resultado do curso de formação de atores, proporcionou a experiência com os elementos da linguagem teatral, seu resultado é uma experiência estética, termo utilizado por Dewey, já citado no capítulo 2, a aquisição de uma linguagem, que possa ser ampliadora da consciência e que possa articular a visão de mundo e os desejos de quem faz.

A proposta do curso e do espetáculo se funde, através de jogos tradicionais da cultura brasileira tornando $o$ ator apto e expressivo para a atenção e concentração do estar em cena de maneira espontânea. À medida que se faz teatro, incluindo as etapas de produção, se aprende teatro. Contudo, muitas vezes falta o embasamento teórico, indicação para leituras que venham complementar o aprendizado prático. 
Como se pode ler na entrevista, llo Krugli considera sua escola ainda incompleta, seu modo anárquico de criação é imposto aos alunos, trabalha-se junto ao mestre como nas oficinas medievais e se aprende o ofício.

Ilo Krugli enquanto mestre da oficina conduz a experiência de seus alunos discutindo em grupo cada passo, não de maneira conceitual ou discurssiva mas, mais uma vez propõe em forma de enigma, vem daí a alcunha de bruxo, sua capacidade de observação do aluno, pelos exercícios que propõe nos levam a conduzir propostas e desafios para resolver etapas que sem se deterem na habilidade técnica conduzem sempre a libertação de padrões, à expressividade, a originalidade. $O$ contato de cada aluno com seu arcabouço de imagens.

A característica mais proeminente de llo é que na condução do espetáculo com alunos ele não determina marcações, elas surgem a partir dos processos dos integrantes, e o espetáculo vai sendo definido a partir da repetição. A concretização das cores e formas em panos e objetos são sugeridos por ele a partir do que foi trazido antes pelos alunos. Para a personagem Geada, que entrava no jardim do gigante egoísta, ele me trouxe um tecido prata que se demonstrou curto para o que se pretendia, sugeriu-me que eu experimentasse movimentos de geada e como eu flutuasse com o pano, rindo de mim, ele me amarrou. Com uma ponta presa do tecido, amarrado em uma extremidade do palco, meus movimentos ficaram curtos e só quando realizei o movimento gelado, mas não esteriotipado e nem banalizado é que entendi o que ele tinha proposto. $\mathrm{O}$ que eu naquele momento de meu aprendizado podia oferecer foi continuamente ampliado para que eu pudesse encontrar uma forma de expressar a personagem.

Se comento que ele ri de nós ou discute conosco é justamente para enfocar a maneira, às vezes, leve e descontraída que assume a direção, o que 
dificulta muito para os atores a compreensão de como ele conduz o processo da encenação. Nos depoimentos em anexo essa característica é citada algumas vezes.

O pensamento visual é concretizado em objetos e em forma cênica através de procedimentos de riqueza extraordinária: pedras, tecido, rodas de bicicleta, latas, pedaços de madeira e outros tantos objetos que possam concretizar sensações e sentimentos.

Frio, solidez, leveza e outras sensações são transpostas para o movimento, são expressadas no uso do objeto, na sua manipulação cênica. Os sentimentos evocados vão aos poucos tomando forma, a vivência através do objeto garante expressividade e espontaneidade.

Pelo amor, tudo! É uma frase fundamental do personagem rouxinol em $O$ rouxinol e a rosa. Em uma das propostas que considero das mais complexas, deveríamos dizê-la sem os objetos. Constatamos nossa dificuldade em dizer o texto, sentados numa cadeira, de chofre, sem nenhum artifício, com um mínimo de veracidade. Não era ainda meu tempo de poder dizer: Pelo amor, tudo!! Mas mesmo assim tive a oportunidade, no decorrer da temporada, que durou dez meses, de exercitar minha curiosidade em descobrir como eu poderia conseguir dizer a frase tão simbólica e enigmática na construção do meu aprendizado em Arte. 
Capítulo V

Desdobramentos

.... e entregou as chaves para outras pessoas...

(...) Muita cousa mais do que isso

Fala-se de muitas outras cousas.

De memória e de saudade

E de cousas que nunca foram.

Nunca ouviste passar o vento

O vento só fala do vento

O que ouviste foi mentira

E a mentira está em ti"

Alberto Caeiro 


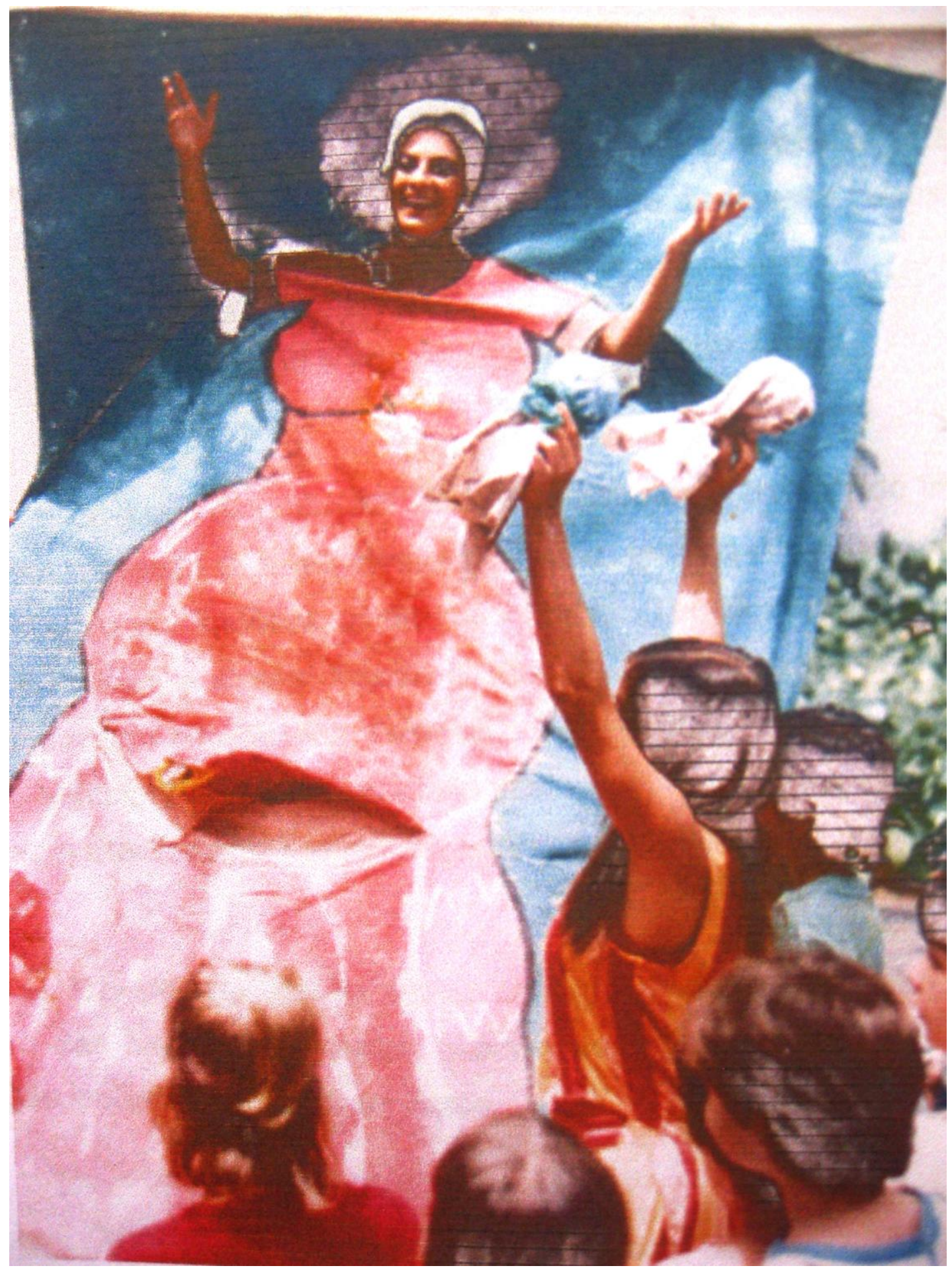

As quatro chaves. Foto Roberto Mello. Arquivo Ventoforte 
A proposta estética-pedagógica do grupo Ventoforte está presente em seu âmbito formador e em seus espetáculos. Alunos que se formaram junto ao grupo ou ex-integrantes levam consigo marcas desse aprendizado seja pela formação subjetiva ou o aprendizagem da linguagem teatral do grupo, ou a visão de criança, um rio cria outros cursos. Vejamos alguns desses outros cursos.

\section{Oswaldo Gabrielli e sua experiência com llo Krugli}

O grupo de teatro XPTO é apontado como tendo sido influenciado pela Bauhaus. Oswaldo Gabrielli, diretor do grupo, relatou em entrevista as influências que recebeu da Bauhaus ainda na infância. Tendo encenado Babel Blum, O Pequeno Mago, e Buster Keaton-O Enigma do Minotauro, para citar alguns de seus premiados espetáculos Gabrielli contou o início da carreira com Ilo Krugli no Teatro Ventoforte, em entrevista pelo telefone e no depoimento encontrado no site do Centro Brasileiro de Teatro para Infância e Juventude ${ }^{83}$.

Oswaldo Gabrielli entrou em contato com o grupo Ventoforte em 1978, no Teatro San Martín, no Uruguai, quando assistiu ao espetáculo Sonhos de um coração brejeiro naufragado de ilusão.

"Utilizando-se de fantoches, bonecos de vara, teatro de sombras, animação de coisas, sem esquecer a importância da presença do ator, o espetáculo apresenta uma diversidade de propostas, integradas numa dinâmica cênica, que segura o expectador e o incorpora à magia teatral. Além disso, esse

\footnotetext{
83 GABRIELLI, Oswaldo. Depoimento prestado à Antonio C. Bernardes em 02-11-2000.
} (http://www.cbtij.org.br/destaque_oswaldogabrieli.htm) 
argentino que está no Brasil há 18 anos sabe fazer uso da nossa cultura espontânea popular, no caso especialmente o mamulengo (...)"84

E afirma ter ficado seduzido pelo charme da encenação, pelo choque cultural que ela representava para a cultura européia.

"A Argentina é um país extremamente racional, europeu. Tudo o que aprendi nos cursos era fundamentado nas escolas francesas, inglesas e italianas $(\ldots)^{\text {"85 }}$

Quando deixa a Argentina e vem para o Brasil, ele procura o grupo que havia se instalado em São Paulo e vivia uma época de mudanças e rupturas, de elenco e de propostas.

"Foi aí, que eu passei de uma visão racional do mundo a uma visão mais sensível do mundo, digamos, mais esotérica. Comecei a ter contato com a cultura brasileira, com a música, com o candomblé. Todos esses elementos colaboraram para desenvolver um lado urbano com nuances místicas, esotéricas. A busca do transcendental. Daquilo que não se vê. Essa forma de observar a vida tem muito a ver com o trabalho do llo Krugli." ${ }^{86}$

Permanece no grupo por quatro anos e participa dos espetáculos Luzes e Sombras, Histórias de Fugas, Paixão e Fogo e em Estou fazendo uma flor; atua ${ }^{84}$ GARCIA, Clóvis. A força do mamulendo aliada ao jogo teatral. O Estado de São Paulo, São Paulo, 23-07-1979.

${ }^{85}$ GABRIELLI, Oswaldo. Depoimento prestado a Antonio C. Bernardes em 02-11-2000. (http://www.cbtij.org.br/destaque_oswaldogabrieli.htm)

${ }^{86}$ Idem. Pág. 2 
juntamente com llo e três músicos. Dirige no Ventoforte seu primeiro espetáculo, Os misteriosos pássaros de barro ${ }^{87}$.

Gabrielli conta que considera llo Krugli um bruxo de movimentar as pessoas por dentro, e que o trabalho com o grupo o ajudou a se descobrir afetivamente, trouxe um olhar de fora para dentro, um olhar interior. As pesquisas do grupo com as raízes e o interior de cada um o levaram a sair para procurar seu próprio caminho, que ele afirma ser muito diferente do caminho do grupo, pois procurava "uma coisa mais urbana" e que sendo de uma geração diferente, se decepcionou com a "caretice" da militância de esquerda, e se envolveu mais com a expressão dos anos 80 , que abria outras possibilidades e que não a de vir na rasteira de ideologias.

Considera que a influência do trabalho junto ao Ventoforte está na forma que, enquanto diretor, trabalha com os atores; diz que, se não tivesse observado por quatro anos o trabalho do Ilo, seria um diretor completamente diferente.

Sobre a estética do Ventoforte, Gabrielli faz várias considerações e comenta que "o llo tem uma coisa da criança interior" e o vê sempre em cena muito autêntico, com verdade interior, o que não acontece com os outros atores que atuam com ele. E, mesmo que seja a "maior loucura", gosta dos espetáculos e que llo criou um estilo pessoal de encenar "a coisa bruta", não a embeleza, é sempre cheio de profundidade, é ideológico e sabe exatamente o que quer.

Concluindo, o diretor do XPTO não vê nenhuma semelhança entre a Bauhaus (que nunca pesquisou, viu uma exposição quando era criança em

${ }^{87}$ GARCIA, Clóvis. Ventoforte: beleza e magia para as crianças. O Estado de São Paulo, São Paulo,22-08-1981. 
Buenos Aires e um video do Balé Triádico de Oskar Schlemmer) e a linguagem teatral proposta por llo Krugli no seu Teatro Ventoforte, e que a pintura de llo Krugli é influenciada pelo Cubismo e pela Arte Moderna.

\section{Ligia Catunda e a descoberta da liberdade}

Ligia Catunda, ceramista, de 67 anos, cursou formação de atores no Ventoforte aos cinquenta anos e atuou no espetáculo Dois Irmãos ou O pássaro de fogo. Em entrevista ela contou do desejo, ainda menina, de cursar teatro e de como a resposta do pai a espantou: Não é uma profissão decente é uma profissão de putas!! Além disso, segundo o pai, só poderia cursar teatro no Rio de Janeiro e ele não queria os filhos longe da família. Assim ela pode estudar um pouco de artes plásticas até se casar. Quatro filhos, dois casamentos, em que os maridos decidiam pela mulher, Lígia só pôde fazer o que queria ao se livrar, como ela mesmo disse, do segundo marido. Começou a fazer teatro no Ventoforte e no início achava as propostas meio hippies.

"De repente você chega numa aula que tem uma pessoa como o llo que te diz: Você traz de casa um objeto bem bonito, que você goste muito, um lenço, uma coisa de cor vibrante. Só isso me deixava meio... que coisa mais maluca, mais hippie..."

No relato abaixo ela conta a importância dessa aprendizado de maneira informal, como pode ocorrer quando os depoimentos são recolhidos com o uso do gravador.

"Lá no llo tem uma liberdade!! Sabe essa liberdade que ele dá !! As festas do Ventoforte são as coisas mais lindas do mundo, todo mundo dança com todo 
mundo, faz aquelas cirandas, aquelas coisas, isso é tudo muito lindo porque isso vem dele, essa liberdade intensa dele.

No meu trabalho tirou minhas amarras, eu fiz uma exposição eu criei um monte de discos...

Me deu uma abertura, para eu me soltar, às vezes você pensa, não vou fazer! A gente está muito acostumado a fazer coisas boas para serem vendidas, isso aí não dá certo para o artista.

Você tem que criar e eu acho que o llo me ajudou muito porque ele via minhas coisas...parece que tem um anjo aqui... Olha... Sabe eu acho que a aula com o llo e com tudo que fazia os exercícios que fazia, com todas as portas que ele ia abrindo me trouxe essa coisa maravilhosa de soltar, que a gente é presa. Eu me sentia assim, aí ele começa a soltar, quando você vê, está voando! Solta a voz, aprende a cantar, falar direito. Tudo me encantava, a aula do Tião de dança que era uma maravilha, aula com Paulo César que era uma desbunde: expressão corporal e o llo né, que é o mágico-rei. Ele tem uma sensibilidade incrível, fala umas coisa e toda aquela música...

Vivi a magia... Cansativa né? Que a gente ensaiou feito uns loucos para fazer aquela peça, éramos 18! Levou bastante tempo!

(...) O respeito à liberdade, a Cultura fez um vídeo e ela perguntava para vários artistas sobre a arte no ensino e eu falei também, tem um depoimento meu aqui embaixo no meu ateliê. Me viram trabalhando, enquanto eu estava trabalhando eles iam perguntando eu ia falando

Foram lá no llo, aí ele falou, eu nunca vou esquecer, que eles perguntaram assim: o que é Arte ? Para que serve a Arte? Ele falou assim: a Arte serve para matar a nossa fome. Achei tão lindo.

Porque é mesmo, é a fome de conhecimento, de liberdade de coisas que você vai extrapolando por aí, você vai colocando no desenho, no barro, onde for, numa dança a liberdade que é essencial para criar, se você for amarrado a 
cânones a coisa não funciona de jeito nenhum, se ele vai aprender do jeito que o professor faz é um absurdo, ele não aprende, ele vai aprender a copiar...

Eu acho que principalmente é essa abertura de porta que faz se eu pretendo eu acho que faço também com os meus alunos abri a porta prá fantasia sair mais livre e não ter medo de ser autêntico, não ter medo de errar. Ser bem autêntico.

Eu me sinto muito irmanada ao llo acho que mudou um pouco o pessoal, as pessoas tomaram outros rumos. Fui muitas vezes levar meus netos

Sempre pecou muito pela falta de divulgação ninguém divulga as coisas do Ilo, ele é um pintor, é um artista, ele é tudo, é muito sensível... Parte prática faz falta.

Ele é uma pessoa que está no meu coração porque ele ajudou a abrir as portinhas da percepção para mim sem nenhum cogumelo."

\section{Confluentes em Curitiba pelo relato de Fátima Ortiz}

$\mathrm{Na}$ cidade de Curitiba onde estreou em 1974 o grupo influenciou permanentemente o teatro infantil. Outros antigos componentes do grupo exercem intensa atividade pedagógica e artística em vários estados brasileiros.

Fátima Ortiz escreveu seu depoimento contando o impacto da estréia do grupo Ventoforte em Curitiba e como llo Krugli influenciou seu trabalho em Arte com crianças.

"Comecei a fazer teatro na escolinha de arte do Colégio Estadual do Paraná no 1aano do Ensino Médio. Não parei mais. Festivais. Cursos Livres. Atriz, já com preferência para o teatro para crianças. Formei um grupo com Enéas Lour 
e Rosy Greca, juntos criamos e produzimos muitos trabalhos endereçado ao público infantil.

Espetáculos premiados: Era uma vez, outra história, A moda de viola e bala, Assim que passem cinco anos, Batimpaz, O guardador de rebanhos, Flicts, O menino maluquinho, A história de pã, Que história é essa?, A fada que tinha idéias, Ari areia, Um grãozinho apaixonado, O menino maluquinho.

Conclui na UFPR (Universidade Federal do Paraná) o curso de Educação Artística (1979). Entrei para a equipe de orientadores do Centro de Criatividade de Curitiba, onde vi a primeira versão da História de Lenços e Ventos e conheci o llo. Em 1980, comecei a dirigir, trabalhar com educadores.

Nesta época foram frequentes os encontros com o llo e também com a Fanny Abramovich, duas pessoas que mais marcaram minha trajetória. Em 82, já exercitava o meu pendor para crianças. Ganhei prêmios, participei de encontros, seminários, comissões julgadoras de concursos de textos. Depois fiz uma especialização em Educação Fundamentada na Arte (UTP).

Desde 95 me dedico prioritariamente ao Pé no Palco, projeto criado por mim que hoje abrange vários segmentos.

Meus últimos encontros com o llo foram no Festival de Teatro Infantil de Blumenau e no Rio de Janeiro, nas comemorações dos 50 anos de teatro infantil no Brasil.

Vi pela primeira vez o grupo Ventoforte e o llo em 1974 no Centro de Criatividade de Curitiba num seminário e festival de teatro infantil promovido pelo teatro Guaíra. Era início do grupo e penso que a estréia da História de lenços e 
ventos. Foi um grande impacto. Tudo novo: o uso dos bonecos desmistificado, com um manipulador/ator circulando na cena e até no meio do público; o canto a dança; os atores fazendo tudo e desestruturando o espaço convencional. A postura do ator mergulhada no lúdico, no mágico, no aqui agora. Muitos grupos novos e a classe artística perceberam as inúmeras possibilidades que aquele espetáculo abria.

Para mim, que estava começando e não tinha os vícios do velho teatro didático, foi fácil captar a essência daquele teatro pulsante e verdadeiro. E pensei: Também quero fazer um teatro legal para crianças! O Ventoforte soprou naquilo que estava latente em muitas pessoas vocacionadas para o fazer teatral dirigido às crianças. A repercussão do trabalho do Ventoforte, penso ter sido a mais marcante e significativa daquele período. Foi mesmo um "divisor de águas"! Teve o mesmo impacto (dizem) que o Casaco Encantado de Lúcia Benedetti, em 1949. Acho que o llo Krugli nos influenciou, não tanto pelas inovações na linguagem cênica, mas principalmente por sua postura diante da criança, da arte e da vida.

Seu teatro prima pela ênfase ao imaginário e ele vive também assim, com aqueles olhos sempre decifrando o mundo, com seu jeito de bruxo, seu senso crítico profundo e suave, enfim exemplo de um grande artista. O trabalho do Ilo repercute até hoje em nossos palcos, nas minhas direções, nos textos de Enéas Lour, nas composições musicais de Rosy Greca, no trabalho do grupo Filhos da Lua e no trabalho dos grupos jovens que hoje agradecem a mim por realizarem um bom teatro para crianças e eu intimamente sempre estendo esta gratidão a muitas pessoas, dentre elas ao Ilo Krugli. "

(Fátima Ortiz, atriz, autora, diretora de teatro e arte-educadora, 49 anos) 


\section{Os anos 80 na formação de Marina Marcondes Machado}

"O Teatro Ventoforte foi um acontecimento muito especial da vida cultural paulistana na década de 80. Penso que, em São Paulo, o Grupo Rumo, Itamar e Arrigo Barnabé na MPB -- e o Ventoforte no teatro -- aconteciam de modo alternativo e levavam muita gente para fora da comodidade de suas casas... Também foi naquele tempo que se fundou o Partido dos Trabalhadores, e um novo Brasil se desenhava.

No meu percurso pessoal, a vinda do Grupo Ventoforte para São Paulo significou a chance de fazer com eles o curso de formação de atores para teatro infantil. Na época o Ventoforte funcionava numa casa na Rua Tabapuã; tínhamos aulas de segunda à quarta à noite e as propostas eram maravilhosas. Uma turma de alunos foi convidada para realizar o espetáculo "Luzes e Sombras", no qual o Ilo dirigia brincadeiras das nossas próprias infâncias, além de colocar em cena depoimentos pessoais dos atores, misturando realidade e ficção, muito antes disso entrar em "moda" no cinema e na literatura. Durante as noites, saíamos para "vivências" pelas ruas do Itaim Bibi, que não era ainda o bairro chique que é agora. Saíamos descalços, levávamos bonecos para passear, conversávamos com transeuntes como personagens... A vida era bela e valia a pena ser vivida. Por essa e por outras eu abandonei, em 1981, a formação acadêmica e passei quase três anos em formação no Ventoforte. Com llo aprendi o que é trabalhar criativamente com crianças: sem metodologia explícita, trabalhávamos simplesmente com propostas semelhantes às que vivenciávamos nas aulas de teatro. Algumas davam certo, outras não, mas não havia problema nenhum nisso: tudo era processual, tudo era acontecimento.

Perto da metade do ano de 1983 já estávamos em cartaz com o Luzes e Sombras por cerca de dois anos. Foi quando o trabalho perdeu, para mim, muito da alegria e do brilho da novidade. Precisava começar a me preocupar em ganhar 
dinheiro: casei e engravidei muito cedo. Parti para a experiência de trabalho em pré-escolas, mas sem nunca deixar a perspectiva do Ventoforte.

Em 1989 ingressei como professora na Escola Municipal de Iniciação Artística de São Paulo, onde trabalhei por quase 12 anos. Graduei em Psicologia e realizei o Mestrado na Área de Artes Cênicas. Minha pesquisa procurou retratar a personagem criança de uma maneira não-estereotipada, numa dramaturgia construída em processo, onde tematizei nascimento, vida e morte. Tenho certeza de que esse percurso jamais seria o mesmo se eu não tivesse me entregado de cabeça às vivências do Vento nos anos 80: para só voltar para a Universidade com bagagem suficiente para pesquisar a linguagem teatral com autenticidade, indo ao encontro de uma arte não-espetacular, intimista e aberta a dialogar com espectadores de todas as idades."

(Marina Marcondes Machado, professora universitária, 41 anos)

\section{O som de Manaus...}

"Nem sabe como me fez bem você perguntar essas coisas pra mim!

Amo o Ventoforte e prá não se esquecer de tanta gente digo o mesmo para meu lindo e carinhoso amigo llo Krugli.

Espero conseguir mandar umas letras legais, pois na verdade gosto de fazer um som! Sou músico autodidata, toquei guitarra de plástico e mesmo desligada dentro da minha cabeça de criança já escutava um barulho bem alto e gostoso dentro da minha alma!

Nunca pensei que ia ser músico, mas os ventos e as águas do mundo foram me mostrando que tocar faz festa e as pessoas se emocionarem quando a melodia, harmonia, ritmo poesia e intenção forem prá integrar as pessoas de alguma maneira ou de outra! 
O Vento eu nem conhecia! Emprestei uma guitarra para o espetáculo lindo, Caminhadas. Ai ganhei um convite pra ver As Quatro Chaves, foi super bom não só o Lindo Espetáculo como também o depois onde tive prazer ao cumprimentar todos os artistas que fizeram uma Festa que dura até hoje! Dali para o Bar do Bigode e uma carqueja onde conheci gente maravilhosa, com sonhos e simpatia e muita Fé no trabalho!

O Vento era uma Casa do Ventoforte e tinha um quintal e um Céu!, Uma Komby "Paloma" muito Samba, Boi, Sincopes, O Vento é muito especial prá o Teatro do Brasil ,pois:

\author{
Sempre tem Cheiro Bom! \\ Perfume da Alma! \\ Das mãos \\ Dos Pés \\ Da Flor!
}

Depois disso aí eu fui ver Caminhadas com minha querida Graziela e meu camarada Tião e o Pedrão do Maranhão! Na música: Marta Ozzetti ( com dois zz e dois tt ) A Marta sempre foi uma Lady e sua maviosa melodia na flauta pareciam seus olhos e sorrisos generosos e brilhantes! Além do som muito lindo do gente boa Pena Vinicius!

Toquei depois também no Caminhadas, 7 poemas, e uma estória ?8 $^{88}$

\footnotetext{
${ }^{88}$ Creio que Edgar Lippo esteja se referindo enigmaticamente aos espetáculos "Qualquer homem é suspeito ou Sete-corações e Histórias de Lenços e Ventos.
} 
Isso foi o melhor presente que ganhei do Vento! Sempre é bom viver isso, parar o tempo e entrar em outra forma de expressão mais nítida e limpa e amorosa e forte e bela e boa por ser simples não, não é simples é a sua calma e verdade! As crianças adoram meu som!

Meu agradecimento por seu interesse em ouvir as pessoas que como eu puderam ter o prazer de viver essas coisas só acho bom poder estar nos mesmos caminhos, acho que quando a gente acredita em uma coisa sobre o que é sua maneira de tocar ou atuar ou qualquer coisa, você tem que tentar tirar disso o Teatro do Homem!

Eu gostaria de estar junto com todo mundo aí tocando no Final Misterioso!

Vô me indo!

(Edgard Lippo, músico em Manaus)

\section{Ventos de Florianópolis...}

Iniciei em teatro em 1976 com um grupo de Santos que se intitulava de Teatro Educativo - TERV. Este grupo dirigido por Roberto Villani mantinha uma pesquisa de teatroeducação. Além dos espetáculos, realizava oficinas para crianças, jovens e adultos. Tenho formação técnica em música.

Em 1986 iniciei no curso de formação de atores no Ventoforte. Eu não conhecia o grupo, nunca havia visto um espetáculo e soube do endereço por indicação de uma pessoa. Eu acredito que a identificação foi muito rápida, amor à primeira vista, me lembro da entrada colorida com muitas árvores, casinhas 
pequeninas... E muito ar... Depois eu descobri que ali ainda tinha água, terra e fogo! Lá conheci pessoas que influenciaram diretamente a minha arte.

Após dois anos participei da primeira montagem: Os dois Irmãos - O Pássaro de Ouro, texto e direção de Ilo Krugli, Direção Musical de Edgar Lippo, com elenco de alunos do curso de Formação de Atores. Esta montagem ganhou um prêmio Estímulo e esteve em cartaz até 1989. O processo de montagem veio do estudo dos contos de fadas. Foi selecionado Os dois irmãos e partindo de cenas improvisadas o llo foi escrevendo o texto.

O segundo espetáculo que participei foi Os três cavalos encantados. Este espetáculo surgiu de um projeto do llo de trabalhar com a literatura de cordel. Eram para ser montagens realizadas com o público e que os contos selecionados mudassem toda semana ou de $15 \mathrm{em} \mathrm{15...} \mathrm{A} \mathrm{criação} \mathrm{do} \mathrm{texto} \mathrm{e} \mathrm{a} \mathrm{direção} \mathrm{foi}$ coletiva, com um núcleo de alunos que tinham trabalhado juntos no espetáculo Os Dois Irmãos. Estivemos realizando Os Três Cavalos por várias temporadas no espaço do Ventoforte e em escolas e eventos.

O terceiro espetáculo que realizei no Vento foi o "Mistério do Fundo do Pote, 1992. Este projeto teve início com oficinas que realizávamos em casas de cultura da prefeitura. Em paralelo aconteceu a montagem do espetáculo com texto e direção do Ilo, com elenco do Vento Forte e alunos das oficinas das casas de cultura que, mais tarde, formaram um grupo: O Camaleão.

Houve ainda um processo de montagem do Visconde Partido ao Meio do Ítalo Calvino, que não chegou à fase final de produção, mas que sem dúvida iria ser um lindo espetáculo do qual eu ainda guardo a metade de um texto.

Indiretamente participei da Tempestade como ajudante do João Maria na confecção de máscaras e bonecos. 
Lembro ainda que durante o tempo que passei no Vento realizávamos eventos teatrais onde tratávamos de colocar o público para dançar, cantar, construir e manipular bonecos e adereços e principalmente participar ativamente do fazer teatral, com sua voz, corpo e espírito. Estes momentos eram mágicos para mim, como se fosse transportado para um outro tempo: de prazer, alegria e comunhão. Realizamos diversos destes eventos no espaço do Vento, no Memorial da América Latina, em parques e praças... Foi principalmente nestes eventos que eu cultivei boa parte do que eu quero do fazer teatral, este contato direto com o público, como parceiro, como fazedores sem distâncias, sem níveis.

Participei no Vento como educador. Primeiramente no projeto Enturmando da Secretaria do Menor e depois do projeto A Turma Faz Arte na Rua perto da Praça da Sé e no Brás. Atuei ainda no projeto do Mutirão - Sem Terra Leste 1 e em casa de cultura municipais e como educador no curso de Teatro da Imaginação com adolescentes no espaço do Vento.

Foi um valioso aprendizado, são histórias e situações que guardo comigo e que sem dúvida nenhuma influenciam o meu trabalho atual. Aprender no Ventoforte se confunde com fazer. Eu aprendi fazendo, errando e acertando, me decepcionando e me alegrando. Desde o primeiro momento fui colocado em situações de fazer, de decidir, de atuar e sentir o resultado disto. A coexistência entre o certo e o errado, o bem e o mal, ficar ou correr foi sendo exposta a mim na prática. É uma aprendizagem viva!

De todas as experiências pelas quais passei gostaria de contar uma. Estávamos trabalhando na elaboração de um painel que iria ser pintado pelas crianças e transformado em peças de cerâmica que enfeitariam a tribuna livre da criança, um palco montado embaixo do vão do metrô do Brás, onde trabalhávamos. Para o dia da grande inauguração do painel o local deveria ser limpo e, assim, uma tropa da Polícia veio uns dias antes e retirou do lugar uma 
série de barracos onde moravam algumas das crianças que participaram da pintura do painel... Esta contradição representa para mim uma das maiores lições que recebi no Vento.

O llo é para mim um grande mestre, ser humano de visão privilegiada $e$ que com certeza ajudou-me a definir rumos na minha vida artística. Durante o tempo que estive no Vento, trabalhei com outros diferentes propostas teatrais (CPT, Teatro Oficina, Butô) e que influenciaram o trabalho que desenvolvo hoje, mas eu vejo no trabalho do llo minha principal referência. Desde os tempos que eu trabalhava no Vento, e até os dias de hoje, sigo com temas e exercícios que ele ministrava no curso, que são inesgotáveis e que de alguma forma chegaram e tocaram outras pessoas com as quais eu venho trabalhando, principalmente na formação de professoras.

A possibilidade de se trabalhar em conjunto com música ao vivo também é uma influência inegável. Outra característica é o olhar voltado para a estética popular, a música, as danças, os bonecos, as cores. Outra característica é o fato de procurar no público um parceiro através de uma relação de troca. Por fim, uma certeza que tive a partir do trabalho com o llo foi a de fazer um teatro para todos, ignorando limites geográficos, políticos, econômicos, religiosos e outros. Democratização da Arte.

Estas características do trabalho do Vento e que se repetem no meu trabalho hoje em dia podem ser observadas tanto no trabalho artístico como na prática pedagógica. Acredito que esta seja mais uma influência do llo a de eliminar as barreiras entre a arte e a educação.

Logo que saí do Vento demorei para conseguir me distanciar daquele trabalho e procurar novos rumos. Hoje faço um trabalho diferente, fruto de outras vivências, mas olhando bem, sempre vejo um pouco de llo naquilo que faço. 
Após sair do Vento eu comecei a me aproximar mais da teoria. Que sem dúvida não era foco dentro do Vento. Hoje acredito que bem dosada a teoria pode colaborar no processo mas a prática ainda é insubstituível.

(Révero Paula Ribeiro, 38 anos. Diretor do grupo Teatro Jabuti criado em 1996 em Florianópolis)

\section{O vento é onde tenho plantado um pedaço do meu coração...}

Comecei minha vida teatral como espectadora. Com 11 anos fui levada por um amigo de meu irmão e assisti Morte e Vida Severina na famosa montagem do Tuca, lembro até hoje que não havia cenários, só a iluminação e os atores fazendo tudo com seus corpos, depois disso ao teatro com a escola, vi A Moreninha com a Marília Pêra e tudo isto ficou impresso em mim.

A vivência veio mais tarde, com 19 anos no Grutemon, grupo de teatro amador que acabou tendo depois várias pessoas trabalhando no Ventoforte, esse grupo foi fundamental na minha aprendizagem teatral, depois veio a ECA, onde fiz Licenciatura em Artes Cênicas, mas o mais importante na minha vida foi sem dúvida o Ventoforte, aonde fiz de tudo, atuei, fui produtora, assistente de direção, professora, coordenadora de curso, faxineira, secretária, etc e tal; e onde tenho até hoje plantado um pedaço de meu coração, paixão que tenho pelo Vento e pelo Ilo.

Minha relação com o Vento começou como espectadora. Em 1976 assisti As Pequenas Histórias de Lorca no Eugenio Kusnet em SP, e pirei totalmente, não sabia nem quem era o llo entre os atores, mas percebi que havia algo que ele colocava no palco de uma maneira que eu nunca tinha visto e que $o$ espetáculo que eu tinha assistido coincidia com o que eu queria do teatro.

A partir daí comecei uma perseguição ao grupo, indo mesmo até Niterói para assistir seus espetáculos, mas sem nunca falar com eles. No meu grupo 
amador duas pessoas que haviam feito um curso com o llo nos dirigiram, mas eu sentia uma dicotomia entre o processo e a montagem em si.

Em fins de 1979, já com a idéia do Vento mudar para SP, o llo deu um curso intensivo e eu participei, entrei para o curso em 1980, mas tive um sério problema de saúde e comecei a participar dos espetáculos a partir de 1983, daí vieram As 4 Chaves, O Flautista de Hamelim, Os Cisnes Selvagens, Brinquedos da Noite, O Muro, O Labirinto de Januário, Choro Lorca (assistente de direção), Sete Corações, Histórias de Lenços e Ventos.

Na área de educação trabalhei como coordenadora e professora de adolescentes no curso para crianças e adolescentes no Vento; trabalhei no Projeto dos Circos, no projeto com crianças da favela, com a Prefeitura e Vento, em projeto na Escola Estadual Aristides de Castro, com a Pró Memória/Funarte e Vento.

Sei dizer que me envolvi de maneira total com a proposta do Vento, e é claro que isto interferiu em minha maneira de trabalhar, de ver a criança e o mundo. Sinto que procurei o Vento porque a sua proposta correspondia as minhas perguntas, e quando saí de lá para morar em outros lugares do Brasil levei comigo uma bagagem preciosa, a qual acrescentei informações e vivências. Mas ainda acredito que o Vento trabalha a base do teatro: o ser humano. Podem haver propostas que enfatizem de outra forma o trabalho do ator e se proponham a finalizar de outras formas os espetáculos, mas o Vento possui uma base muito importante quando valoriza o homem e sua história como base de qualquer processo artístico.

Para mim, a base de qualquer processo artístico tem que partir do ser que produz esta arte, seu mergulho interior que possibilitará passar ao mundo uma visão que tenha conteúdo que possa impressionar ao público. 
É sempre importante falar, pensar e reviver o Vento com seu povo, sua história, sua magia e principalmente com o llo que considero meu mestre e que sempre foi mágico na vida de todos que puderam trocar com ele.

(Selma Bustamante, 47 anos, professora de teatro na Universidade de Manaus em cursos técnicos e livres. Diretora e atriz, produtora, faxineira, secretária e etc no Grupo Baião de Dois, que fundei na saída do Vento e atua aqui em Manaus)

\section{Henrique Sitchin e o olhar sobre A História do Baquinho}

Comecei a fazer teatro em 1985, mais como exercício interno de crescimento e auto-conhecimento do que propriamente com o objetivo de comunicar-me com o mundo. Em 1987, no entanto, assisti ao espetáculo História do Barquinho, de llo Krugli, e considero aquele um dos momentos mais marcantes da minha experiência com o teatro, e que me fizeram mudar o "olhar" que eu dedicava à minha ocupação. Fiquei muito impressionado. Era como se uma nova possibilidade se abrisse no que era, até então, o meu universo teatral. Encantoume a simplicidade, a fantasia, a poesia... Em palco havia um homem de aparência quase frágil, mas que revelava-se um gigante, tamanha a facilidade, e ao mesmo tempo a força, de seu poder de comunicação e de produzir encantamento.

Era a expressão do trabalho de um artista especial, daqueles capazes de, com um único olhar, tocar fundo em nossas almas. Aprendi que aquela deveria ser a magia do teatro - a emoção de tocar almas... Ilo Krugli, naquele dia, mostrou-me que era possivel um teatro em que um simples lenço seria dos mais completos personagens, de uma grande fantasia. Era também possível construir a fantasia com as mãos, ou, como mais tarde o ouvi dizer, transformando o sangue de nossas veias no instrumento de fruição da vida que chega ao espectador. Venho tentando seguir este caminho... 
Ilo impressiona-me até hoje. Ultrapassados os 70 anos de vida, segue trabalhando com força e determinação invejáveis. E com uma poesia que, a essa altura, parece haver tomado conta de seu corpo. É como se já não precisasse dizer quase nada, fazer quase nada. Ilo parece haver alcançado um lugar único, reservado, de fato, a muito poucos. Um olhar, uma pequena palavra, um único gesto revelam o verdadeiro Mestre.

São Paulo, 05 de Fevereiro de 2003 (Henrique Sitchin, diretor da Cia. Truks - Teatro de Bonecos)

Navegando sem âncora até que...

Minha formação vem do teatro amador de Goiânia, quando vim pára São Paulo me identifiquei com o projeto do Ventoforte por diversos motivos, principalmente com a ligação com a cultura popular brasileira. Como já manifestava interesse em diversas linguagens como artes plásticas, dança, literatura e música, alem do teatro, a vivência no Ventoforte não só ampliou minhas tendências como sedimentou um processo criativo que tenho aplicado nos últimos 15 anos.

Comecei no Ventoforte como aluno, em 1986, fiz o curso de formação de atores regularmente e montamos o espetáculo Os dois irmãos ou o pássaro de ouro em 1988/89. A partir daí recebi um convite do llo para ser assistente de direção na montagem de A Tempestade, fiz estágio em arte educação e fui orientador em diversos projetos de oficinas e arte educação. Fui professor no curso de formação de atores para adultos e dirigi o espetáculo Uma Rosa para Bela que foi a formatura da turma de 1992/93. Como assistente substituía o llo em suas aulas em diversas ocasiões. Participei ainda do espetáculo O Mistério do fundo do Pote e outros projetos que não chegaram a estrear. Permaneci no grupo até 1995. 
O Ventoforte tem esta característica de integrar as linguagens artísticas, o que fez com eu desenvolvesse varias habilidades latentes, principalmente a direção e criação dramatúrgica, as quais me dedico atualmente. A arte educação foi outro veio que o aprendizado no Ventoforte abriu como possibilidade profissional. A forma do aprendizado se deu de maneira orgânica, embora eu tenha a tendência a sistematizar os processos criativos, mas a confiança e dedicação exigidas pelo processo proposto pela escola mostraram que o caminho valia a pena e posso dizer que houve um grande ganho no sentido de lidar com a intuição e perceber os caminhos que a própria arte nos indica.

Neste sentido a proposta estética do Ventoforte foi determinante para que eu pudesse sintetizar e reconhecer as características do meu trabalho enquanto artista e educador. A condução do processo criativo aplicado no Ventoforte tem sempre um olhar especial para cada indivíduo e ao mesmo tempo ao grupo. Esta percepção é fundamental para que um orientador possa encaminhar um aluno para o desenvolvimento de suas tendências.

A cultura popular nos ensina ha séculos que podemos aprender vivendo a experiência, o pai que ensina ao filho aquilo que aprendeu com o avô. Uma escola pode nos dar grandes referências teórica, mas deve, sobretudo permitir este acesso ás experiências dos outros e às suas próprias experiências, assim penso que o aprendizado da arte passa por este canal do sensível quando nos percebemos num contexto geral e podemos nos relacionar com o que acontece no aqui e agora. O llo sempre nos disse que o artista é um artesão que transforma com suas próprias mãos a matéria e imprime a sua marca pessoal no resultado final, mas devemos resguardar, sobretudo as experiências que o processo nos revela, muitas vezes mais intensa que o próprio resultado.

Cada processo é um processo. O que talvez podemos dizer que há de comum em uma ou outra montagem é o fato de que a construção de um espetáculo se faz nos ensaios, no palco. Um ensaio determina a necessidade que 
será trabalhada no próximo ensaio. Uma cena abre a perspectiva para a outra cena, nada é muito planejado neste sentido. Valorizam-se assim as descobertas dos artistas envolvidos. Talvez aí esteja a maior dificuldade de se entender racionalmente o processo criativo do Ventoforte. Trabalhamos com o imponderável, com a transformação. A maioria das pessoas, a meu ver, necessita de um porto seguro, no Ventoforte é como A História do Barquinho navegamos sem ancora até aprendermos como baixar e levantar a ancora, entre estes dois momentos estaremos sujeitos às intempéries da vida e da construção artística. É só navegar... (Wilton Amorim, 40 anos, diretor e autor teatral, arte educador nas linguagens de teatro, artes plásticas e literatura)

\section{Beto Andreeta e a Pia Fraus}

A Pia Fraus existe há 19 anos, formada desde o início por Beto Andreetta e Beto Lima.

Somente eu tive uma relação mais próxima ao Ventoforte, nunca tendo sido parte do grupo, mas um aluno que praticamente morava no teatro; não participei da criação de nenhum espetáculo do Ventoforte, apenas fiz uma substituição em um espetáculo já estreado ${ }^{89}$ (desculpe, não lembro o título do trabalho).

Nos anos de 1981 e 1982, tive aulas com Paulo César Brito, Thaia Perez, Oswaldo Grabrielli, Graziela Rodrigues e llo Krugli, creio que sem essa equipe profundamente inspirada e criativa, o trabalho e a linguagem do Vento Forte não seriam tão significativos.

Acompanhando a trajetória do Ventoforte, percebo que a qualidade/criatividade de seus espetáculos variam muito de acordo com suas equipes e creio que tive a sorte de presenciar e vivenciar o que na minha opinião, foi até agora o ápice da linguagem do Ilo. Depois de mais ou menos, 1985,

89 Segundo Rosa Comporte o espetáculo ao qual Beto Andreeta se refere é Brinquedos da noite. 
percebo a repetição de uma fórmula consagrada neste período (75/85), já sem o mesmo vigor criativo.

Do Ventoforte trago comigo o grande respeito a sensibilidade e inteligência do público infantil e a prática de um teatro que parta do interior da alma humana e não uma mera técnica de representar.

Ainda no ano de 1983, realizei uma turnê de um ano por Bolívia, Peru, Equador e Amazônia profundamente inspirada pelas histórias de viagens pela América do Sul, que escutava de llo e Oswaldo, viagem esta, que foi a primeira de uma série de viagens internacionais, que até hoje a Pia Fraus realiza.

(Beto Andreetta, Ator e Diretor, 41 anos, Pia Fraus Teatro)

\section{Processos de criação do grupo Ventoforte por Fátima Campidelli}

Fátima Campidelli, atriz e arte-educadora, 42 anos; foi integrante do grupo Ventoforte e atuou em vários espetáculos, foi uma das professoras do curso Teatro da Imaginação. Em seu depoimento ela relata sua entrada no grupo, seus processos de criação nos espetáculo Labirinto de Januário, A Tempestade, As quatro chaves, Choro Lorca e Sete-corações, O mistério do fundo do pote ou como nasceu a fome. A experiência contínua é relatada em sua prática como educadora no SESI, professora de teatro de adolescentes, nas propostas elaboradas por ela e seus alunos.

O depoimento escrito por Fátima Campidelli, assim como quase todos, foi elaborado a partir de um roteiro de perguntas que buscava conhecer sua experiência com o grupo, seu conhecimento dos espetáculos pelo olhar de quem cria e sua visão de ensino de arte a partir do encontro com o Ventoforte. 
No início tudo girava...Ele ainda está dormindo. O sonho dele demora, os sonhos de muita gente junta. Enquanto nós sonhamos trezentos e sessenta sonhos... Ele sonha um só.

Este texto era dito pelo Mágico, no espetáculo Da metade do caminho até o país do último círculo; refere-se ao Gigante azul, um menino que nasceu azul e não mais parou de crescer.

Abro com esta imagem de sonho, o processo de elaboração de um espetáculo no teatro Ventoforte. Um mergulho profundo, sem pressa, com carinho de mestre, o Diretor espera o sonho acontecer. O sonho de todos, que devagar vai virando o espetáculo! (...)

O teatro apontou na minha vida, graças a um ímpeto, nas festas da escola, gostava de falar poemas, homenagens... Morria de vergonha, meu coração batia forte, mas eu adorava. Um grupo na escola, passagem rápida no curso Macunaíma, um curso com o Osmar Rodrigues Cruz, no SESI da Paulista, estímulo, passear pela periferia de São Paulo com o espetáculo Pedro Mico. A Companhia Carroça de Ouro (Comédia dell'arte), namorar o Teatro União e Olho Vivo, casar com o Ventoforte numa experiência definitiva para este adorar.

Eu fui somente para fazer um curso de férias, me apaixonei, porque pela primeira vez, dentre tudo que já havia feito, estava ali presente o meu ser, minha história, minha mãe, a pequena cidade onde nasci, onde coisas mágicas faziam parte do cotidiano. E no Vento, no pequeno palco da casa da Tabapuã, a magia estava ali mergulhada num caos de panos, objetos grandes e pequenos que envolviam o grupo e nos transportava e nos fazia sonhar. Eu enlouqueci! 
Ainda estava no Olho Vivo, mas por pouco tempo, logo estava fazendo os ensaios para o Labirinto de (...) mas o processo era rápido já fazia parte do grupo e estava no elenco da História do Barquinho e das Quatro Chaves, produzíamos muito, oficinas, festas, cursos...

Estreamos o Labirinto com quatro horas, uma senhora muito simples se levantou e agradeceu a maravilhosa tarde, era no teatro da Penha, diminuímos para duas horas o tempo do espetáculo, ganhamos vários prêmios, como o Moliére, não tínhamos público. O grupo tinha crises, às vezes alguém saia, o básico que éramos nós: Paulinho (Paulo César Brito), Rosa, (Rosa Comporte), Laurent (Laurent Lucien), Selma Bustamante, Edgar, (Edgar Lipo), Luís Luís Laranjeiras) continuávamos.

Mudamos para o Parque do Povo onde ainda está o Ventoforte. Vieram os espetáculos: Choro Lorca, Lorquinha (Sete Corações); comecei a dar aula para crianças monitorada totalmente pela Selma, nós montávamos aula juntas e depois eu contava a ela, exatamente o que tinha feito, foi um grande aprendizado. Era lindo o Choro Lorca, ousado o Sete Corações, as Quatro Chaves continuava, sempre, até hoje.

Comecei a nadar com o Sato às seis horas da manha, este encontro zen com a água, me fez ver melhor a linguagem teatral do Vento, foram anos nadando e coincidentemente adivinhei o próximo espetáculo, a Tempestade de Shakespeare, ganhei de presente o Ariel. Nos ensaios deixava me transportar pela água com movimentos que vinham da natação, o Ariel era fascinante, ele levava objetos, como se fossem armas compondo personagens, aparecendo e desaparecendo. 
O llo me convidou para dar aulas no curso da Imaginação, eu trabalhava com os elementos da natureza o llo me ajudava, comecei a segui-lo, ficava observando-o a dar aulas, às vezes desenhava as pessoas, dançávamos a Ciranda no Mutirão, (oficina com jovens e senhoras do Mutirão São Francisco), fiz o curso na USP com a Ingrid Kondela, ela gostou muito da maiêutica da aula que apresentei.

Arquivo Diário de Ensaio: Espetáculo A Tempestade

Dia 20 de Dezembro de 1988.

Fizemos barcos com caixotes, papeis panos e bonecos. No final desenhamos e pela primeira vez entendi o que era sensação e conceito. Jogamos um copo de água sobre o desenho, e tudo se transformou sem controle.

Dia 07 de Dezembro de 1988.

Construímos uma ilha com objetos. E o grupo saqueava, a ilha de cada um. O Paulinho contava sua história, de como havia chegado àquela ilha, depois nos entregou até as calças.

Dia 13 de Dezembro de 1988.

Ilo: Porque você parou, porque não aproveita o que ti vem, sem que você tenha pedido?

Dia 13 de Fevereiro de 1989. 
Conversávamos sobre o punhal de Caliban, o símbolo que ele dá ao Próspero, que permite a saída de Ariel e também provoca a morte do Próspero. $O$ llo tinha dúvidas às vezes achava que o Caliban deveria interferir nesta morte, deixamos o tempo correr...

Dia 20 de fevereiro de 1989.

Conversamos sobre o espelho da Miranda. Que é um paralelo, que ela conversa com ela mesma. Com o seu duplo. Também a máscara de homem, que Próspero coloca em Ariel. Próspero: - É só uma mascara de homem, Ariel, experimente, mas não te apaixones por ela, porque, se ela ficar muito tempo no teu rosto, depois vai ser difícil tirá-la.

Dia 23 de março de 1989.

O llo veio com uma idéia bastante interessante, cortamos grandes silhuetas no jornal, com rasgos que as tornavam humanas. Começamos a trabalhar com a respiração, que era ora do Ariel, ora do Caliban. E com a frase: "De mim nasce Ariel", "De mim nasce Caliban".

Dia 25 de maio de 1989.

Faz tempo que não escrevo sobre os ensaios, já temos várias cenas esboçadas, tudo se entregou panos, caixas, papéis, folha, areia, mas ainda estamos longe da estréia.

Estreamos em setembro, um ano de ensaio. Viajamos para Córdoba, na Argentina, fizemos temporada no João Caetano e no Ventoforte.

(...) começamos a ensaiar, sem o texto, construímos barcos com caixas, bambus e naufragávamos, criávamos ilhas com sentimentos de poder, inveja e conquista. A princípio, nenhum de nós tinha personagem definido, ainda era 0 mesmo núcleo de atores, com algumas baixas e alguns ganhos, estávamos 
trabalhando juntos há anos, havia entre nós uma intimidade muito grande, não era preciso mais do que um olhar para perceber se um de nós estava em dificuldades teatrais, nos ajudávamos, acolhíamos, brincávamos e criávamos imagens, a partir do caos, jornais, panos, varas longas, caixas, água, terra e espaços. A Tempestade de Shakespeare era transformada todos os dias, o llo já havia mexido no texto em função de um texto sobre o Caliban de um autor latino e nos propúnhamos muitas coisas. Hoje depois de saber o que é teatro Colaborativo, creio que era isto: Colaboração!

Fiz o Ariel, estava bem, me sentia bem, meu corpo estava muito presente no palco, era rápido o Ariel, sempre pronto a ajudar, a obedecer ao Próspero, feito pelo Ilo, conservamos muito, chegamos a conclusão que o Ariel deveria ter ferramentas, objetos. E juntos criamos várias armas esquisitas que compunham e desenhavam no espaço, uma figura mística. Quem narrava a história era um grupo de palhaços, em cena havia três tinas com água, folhas e terra. Os espaços eram extremamente aproveitados, percorríamos todos os lugares, patamares e buracos do teatro. As mesas e cadeiras se transformaram em barcos, os panos em navios, os corpos em bichos, a música ao vivo acompanhava, dando ao espetáculo a magia.

Fizemos temporada no Ventoforte, o ritual da preparação, a espera, as roupas, os detalhes dos objetos que eram muitos, a maquiagem pesada $e$ pouco público. O que acontecia, não entendíamos ou talvez não víssemos o lado mais prático do teatro.

Ensaiar dois anos para se fazer o Labirinto do Januário, que foi para mim, apesar de um processo sofrido, o mais intenso que vivemos enquanto o grupo. Éramos jovens e muito apaixonados, começamos me lembro, a ler o texto no palco da casa da Tabapuã. A história se passava em um grande labirinto (a 
cidade grande), brincávamos num primeiro momento de narrar a história, loucamente, sem se preocupar com qualquer lógica.

O Ilo, atento, éramos jovens na linguagem. O VentoForte sofria o processo de mudança, muito atores haviam saído. Era só mais uma crise, das tantas que passaríamos juntos. A lembrança mais forte que tem desses ensaios é a construção do labirinto. O llo fez um grande quadro de madeira, como um grande tear; a Andorinha que era muda, ia tecendo nesse tear caminhos com fio enorme, como Ariadne do Minotauro. Este quadro começava no chão em determinados momentos, ele subia, se inclinava, e nós, nos movíamos entre estes planos, o que era trabalhoso e complicado. Havíamos criado vários bonecos, pois todos faziam vários papéis. O Ilo, atento, aproveitava cada momento do ator: o jeito de usar o boneco, uma brincadeira antes do ensaio...

Quando fomos para o terreno do Parque do Povo, o Labirinto se espremeu numa sala com chão de terra, ensaiávamos descalços, os elencos sofriam, havia o personagem Fumaça que era filho da água e do fogo, que mudava sempre de ator, era difícil o processo, discussões, cansaço...

Passamos para outra sala, havíamos inventado muitas cenas, inúmeras, o llo caminhava dentro do processo, numa troca constante, mexia e remexia no texto, em função de coisas que propúnhamos, aprendíamos a cantar, decifrávamos os códigos de uma mãe e pai que só tinha uma roupa e ficavam esperando enroladas em uma toalha, que a roupa secasse, mas haviam roubado a roupa do varal e por muito tempo eles não poderiam sair.

A guerra entre os Louros e os Mouros, os bonecos, muitos e também tantas trocas de roupa. A força do Folguedo Popular, a Cavalhada, o universo da criança, aprendíamos inconscientemente a linguagem teatral. 
Para mim era mesmo o envolver-se sem pensar, estava ali de corpo e alma, tinha enorme prazer de descobrir coisas. Todos os objetos tinham características dadas pelos atores, meu boneco, por exemplo, tinha a boca que abria meio metro, este personagem ajudava o capitão dos Louros. O Ilo pretendia fazer um teatro especialmente para o espetáculo, com túneis, passagens que fariam as cenas aparecerem como mágica, como labirinto. E não havia dinheiro, íamos porque queríamos, o grupo ajudava na construção dos objetos, na costura, na limpeza...

Quando ficou pronto, durava quatro horas, eu tinha nítida impressão que entrávamos em um sonho, porque todos tinham muitas funções, ninguém parava sequer para olhar o outro nas coxias, era tudo em função da história. Era estar na história, crescemos muito neste período, como atores, como pessoas, como grupo... Que estava pronto, tínhamos um repertório, fazíamos festas, oficinas e assim, fazer um outro espetáculo era quase um refresco, então fizemos dois que apelidamos de Lorcão (Choro Lorca) e o Lorquinha (Sete Corações).

A produção do Ventoforte nesta época era intensa, havia muito, muito trabalho e sempre comemorávamos todas as festas, com oficinas que eram rituais teatrais, com a participação de todos, crianças, adultos. Nesta época apareceu um rapaz da USP, que fez um filme sobre a Casa do Ventoforte. Bem... Choro Lorca eram dois textos do Lorca, A Sapateirinha Prodigiosa e o Romaceiro Gitano. Eu sofri muito neste espetáculo, houve, como que uma selação para o elenco, e de algum modo, a princípio não me sentia a vontade.

Começamos a brincar com cadeiras, pesquisamos este objeto, ao mesmo tempo aprendíamos coreografias flamencas, (e eu me saía muito mal) havia um ator que me maltratava, o llo me defendia, um dia tomei um drink na 
padaria da esquina, nós fazíamos uma cena no patamar, representando a lua, era Lorca, tirei a blusa ofertando os seios para a lua, como se fosse a lua, o diretor adorou, talvez na época ele gostasse da minha pessoa, porque em cena principalmente nos ensaios, eu era capaz de ter idéias malucas e ousadas.

O grupo era complicado! À tarde ensaiávamos o Lorquinha (Sete Corações), com uma proposta interativa e simples, contávamos a história do poeta Garcia Lorca. A morte! E a partir daí a estrutura do espetáculo se modificava, o público assumia os papéis dos atores, dava-se à passagem através dos bonecos, depois fazíamos poemas com o público, a Guarda Civil matava todos os poetas, que eram ressuscitadas com poemas sussurrados no ouvido. Era emocionante e divertido.

Às vezes apareciam crianças da classe média alta, que queriam, é claro, ser o Rei, e se transformavam rapidamente em ditadores. Os pais, assustados, tentavam dissuadir o filho de tanta violência, mas o Rei mandava prender o próprio pai ou até matá-Io. Este trabalho, as oficinas, as Quatro Chaves, nos possibilitaram a oportunidade de trabalhar de uma maneira direta $e$ espontânea com o público, aprendizado que até hoje uso, nas aulas, em eventos, na vida!

Fomos para Europa, tentamos montar O Mistério do Fundo do Pote, e tudo girou, numa gravidez súbita, várias não só a minha. Entrei no SESI, dirigi vários espetáculos: Arthur Azevedo, Shakeaspere, Lorca, Ilo Krugli. Atualmente trabalho no Teatro do SESI em Osasco, dando continuidade ao Ilo, ao Vento que ficou em mim. Aprendi muito com o llo, ver os detalhes, as sombras nos rostos e na natureza, ser humilde e apaixonada por um trabalho que ainda adoro, com aquele mesmo ímpeto que me fazia me expor nas festas da minha infância. 
O Ariel foi para mim o momento ápice de estar no Vento. Por que se vai a Europa? Como Caliban... Digo como colonizador ou como colonizado. Fomos como colonizados, e trabalhamos muito em uma feira chamada Juvenalhia, novas crises, desfalque no grupo, outra montagem O Mistério do Fundo do Pote, o grupo estava cansado, perdeu a força, o mundo estava diferente, agora se pensava em dinheiro, até se ganhava.

O espetáculo não acontecia, minha criatividade também não, o grupo estava recomeçando de uma maneira estranha, era como retornar ao estágio do Labirinto. No final estreamos sem dinheiro, com coisas inacabadas, lembro que havia uma cena que a personagem deveria fazer, uma cena junto a uma tela com o filme do Carlitos e não conseguimos a câmera, e assim a tela ficou em branco, eu estava grávida e tinha enjôos, as tardes estavam quentes.

O espetáculo naufragava. O llo, porém, sempre me surpreendia nele a vontade, não se esmaecia nunca, ele adorava fazer o espetáculo com uma força, ou com a mesma que o vi agora dizendo um texto lindo no espetáculo Portal das Maravilhas. A sua presença no palco tem a dignidade de quem atravessa as portas da vida com emoção.

Trabalhar com criança

Estou tentando relatar um processo, de uma aula, com o tema imaginação e sou atropelada pela lembrança de uma experiência que tivemos, com crianças dos cortiços no Brás.

Trabalhávamos embaixo da estação do metrô, em frente à Central de Triagem das pessoas que vinham de todos os cantos. 
As crianças nos encontravam ali, naquele espaço de vida, vinham de pequenos quartinhos, perdidas, num labirinto de corredores.

Eu e o Luís Laranjeiras formávamos uma dupla, íamos à tarde. As crianças vinham arrumadas, sujas e lindas. Nós fazíamos grandes rodas, construíamos bonecos, dançávamos no cinza.

O trabalho fluía bem! E num dia especial, ocorreram coisas, que misturavam a vida, a morte e a proposta.

Neste momento, além das crianças dos cortiços, outras crianças já haviam se aproximado, as da rua, as que chegavam de longe e estavam ali acompanhadas, esperando literalmente o Destino.

O llo nos deu como proposta fazer o Mapa da Vida, que em síntese é desenhar, o antes de nascer, o presente e o futuro. Neste dia, o Luís não pode ir e fui com uma moça estagiária, chegamos cedo e nos sentamos à espera das crianças. Casualmente nos sentamos perto de um grande embrulho de papelão. $E$ a moça me contou que estava grávida, pretendia fazer um aborto, ela estava emocionada, alguém se aproximou e nos perguntava se havíamos visto o morto. Não sabíamos... Ela continuou a falar da vida, da dúvida entre a vida e a morte, e as pessoas continuavam a nos perguntar: vocês sabem onde está o morto? Me disseram que estava aqui...

As crianças chegaram alvoroçadas, também elas nos perguntaram do morto...Fomos para o parque, dançamos coisas com barrigas, umbigadas. Construímos no trepa-trepa (brinquedo), com panos, papéis, barbantes, uma grande barrigona. E ficamos lá dentro, pequenos não me lembro do que falávamos, mas sim da luz que nos chegava tênue, azulada. Às vezes alguém 
nascia, olhava o mundo, voltava para dentro da barriga e se aconchegava, para voltar a nascer...

De repente, uma sirene... Nos abortou de uma vez só para fora. Era já um grande caixão preto sobre rodas, era o carro negro do IML, chegou e estacou perto do grande embrulho de papelão, aquele que sentamos perto.

As crianças correram e se empoleiravam nas grades do parque, nós duas também, corríamos divididas, entre a continuidade da aula, a curiosidade e a preocupação que as crianças vissem o morto.

E todos nós vimos o morto! Era o morto indo embora, éramos nós nascendo, era uma barriga grávida de muitas crianças limpas e bonitas ainda que cheirassem mal, ainda que às vezes não conseguíssemos abraçar, tal a brutalidade do cheiro e da visão terrível dos piolhos...

E tudo girou... Por cinco minutos, revi a praça, mas não do chão, como se eu fosse uma passageira de metrô, olhando lá de cima, vi as rodas coloridas, os bonecos, a grande barriga, as grandes filas dos pontos de ônibus, ouvi os palavrões que as crianças já sabiam, a menina de cinco anos me dizendo como a minha vida era fácil, difícil era estar ali na praça, sem paredes, sem banho esperando. Tudo isto durou cinco minutos.

O IML foi embora as crianças, gritavam e corriam enlouquecidas, nós e algumas crianças desenhávamos a barrigona, e não conseguimos mais controlar o que era incontrolável. Ficamos, tristes, desorganizadas. As crianças no outro dia desenharam, a experiência da barriga, e nos surpreendeu, elas se desenharam 
dentro das barrigas dos pais, das mães, havia detalhes, havia morte, eram lindos e orgânicos.

Como se trabalha com crianças? Tem receita?

Trabalhar com o llo é revisar o universo infantil, onde é permitido, a emoção, os sentimentos do bem e do mal e a possibilidade de brincar. Respondame rápido: Por onde andam as suas mãos e onde caminhavam seus pés? Qual é a sua mão de criança?

Usar o que the oferecem sem que você tenha pedido, envolver-se com um objeto, deixar o movimento fluir, sem ter nada que não sejam sensações.

Meus pés caminham pela água e minhas mãos se arrastam pela terra. Deixar o objetivo, de levar, de acreditar nele, não sou eu (pensamento) que está no comando, quem me leva é a imagem, de imaginar de ver e sonhar. Como o menino que toca na madeira, e no seu deslizar acontece o barco ou quem sabe $o$ carro.

Quem determina a imagem, o movimento ou o pensamento?

Parece simples os adultos sofrem, o adolescente desconfia, a criança nos leva junto. É preciso ter um grande olhar, perceber com que grupo se trabalha, sentir o que aqueles seres esperam do seu trabalho com a arte, o que propor quando deixar se modificar o que se propôs. O llo dizia: "Vamos levar materiais, barbantes, panos, papéis, a gente nunca sabe onde a proposta vai nos levar...” 
O encontro do desenho, das formas, de deixar concreto o que sentimos, o que percebemos, deixar este sentimento participar concretamente do mundo.

As rodas, estar de mãos dadas, sentir o movimento que se repete os olhos circulando junto com os olhos da roda, o contato dos pés das mãos. Integrando o homem a natureza, procurando a percepção de um ser que é múltiplo, tem ancestralidade e vive num mundo que esta em ampla mutação, que não pára, que não dá tempo para ver com outros olhos, que não a palavra, o verbo.

Perceber o presente, estar no presente, não ter medo de errar, ou melhor, deixar o erro te mostrar o novo. Porque o teatro, a arte tem este grande aliado: o erro.

Não sei explicar claramente, teoricamente, o que faço hoje nas aulas e nem o que o llo me ensinou. Integrei! Já não penso tanto nas aulas que vou dar, escrevo as idéias em papéis que acabo esquecendo de levar, percebo as pessoas, brinco junto, procuro ser feliz.

Quando começo um processo de direção, nunca sei como vai ser o espetáculo, começo brincando com imagens e objetos, com idéias, que percebemos no texto, primeiro sem lógica alguma. Entro num estado maravilhoso, que é estar próximo de um sopro divino, durmo e acordo com idéias de cenas passando pela minha cabeça, e não as chamo, elas vêem. No ensaio experimento, conto ao grupo e eles acrescentam coisas, criam juntos. E isto é tão maravilhoso que me entristeço quando o espetáculo está pronto. 
Herdei do llo também a vontade de estar no palco, entro em cena, às vezes improviso, os meninos também, percebo no corpo deles coisas minhas e também o contrário, enlouquecemos juntos fazendo com que o espetáculo não se feche, como se fosse festa popular, onde o teatro envolve e faz o público estar junto na mesma brincadeira. E é assim um delicioso sonho de viver o teatro!

\section{Da metade do caminho até o país do último círculo}

"Para fazer uma história de sorrisos com alguma lágrima" (Charles Chaplin)

Depois de tantos anos, trabalho no teatro do SESI em Osasco, onde tenho um núcleo de atores-alunos, que estão trabalhando comigo há seis anos. Escolhi junto com a minha chefe Sônia Machado, que também passou pelo Ventoforte, o texto do llo Da metade do caminho até o país do último círculo. Que eu não conhecia e desde o primeiro momento sabia estar diante de um grande desafio:

1) Ele foi escrito para ser representado em dois dias;

2) Era grande, com caminhos e histórias que se cruzavam, era muito clara a presença e a dinâmica do Ilo. Como ator, ele fazia o mágico, e eu sabia que o jeito com que ele conduzia a história em cena era determinante.

3) Como era fazer um espetáculo onde na minha experiência com o Ventoforte, tudo ocorria organicamente? Deveria marcar o espetáculo ou não?

4º) Discutíamos o texto e alguns atores tinham dificuldade de entender a história.

Comecei bem devagar, trabalhando primeiro com objetos que eles escolheram, que representavam e contavam a história. Resgatamos as músicas que faziam parte do repertório do Vento e os meninos pesquisavam os ritmos intuitivamente. 
Eu quase não dormia, ou melhor, dormia um pouco e acordava preocupada, o que poderia fazer, ao mesmo tempo me lembrava dos espetáculos feitos com o llo. E era incrível como eles pareciam se encaixar como numa colcha de retalhos no texto Da Metade do Caminho.

Assim, avisei o llo e assumidamente usei cenas de vários espetáculos fazendo uma homenagem ao Ventoforte. Cenas de espetáculos do Ventoforte que foram usadas para a construção do espetáculo Da Metade do Caminho: Abertura: Quatro Chaves e A Tempestade. Prólogo: Labirinto de Januário e O Mistério das Nove Luas.

Através do projeto Ademar Guerra, o diretor Alexandre Mate nos ensinou coisas de circo, sem interferir na direção.

Numa noite acordei e li o texto, atentamente, grifei todos os trechos que achava importante e que me emocionavam. O meu objetivo era diminuir o texto, simplificar a história. Continuávamos discutindo no grupo o destino do espetáculo. Enquanto brincávamos de sonhos de magia e de espaço. Ainda construíamos materiais com a ajuda de algumas mães.

Era a primeira vez que eles iriam trabalhar com bonecos, eu estava retomando uma trajetória, definindo uma linguagem que estava camuflada nos meus espetáculos anteriores e que agora me expunha diretamente diante dos olhos azuis do Seu llo.

Chegamos a um roteiro, simples, complicado, que permitia, pelo menos acreditávamos, que o público entendesse a história. Havia ainda alguns pontos extremamente difíceis, como as bandeiras que os meninos traziam do país da Guerra, do país do Silêncio, do país do Sim e do país do Não. O que fazer com o Gigante e por que o João João morria e depois ressuscitava. Discutíamos muito isto, matamos o João João, não matamos, eu não queria mudar de uma forma que mexesse tanto com a estrutura do texto. O autor está vivo! 
O processo durou nove meses e um mês antes a Sônia Machado foi ver e achou tudo uma bagunça! Fiquei de fora da cena e olhei com olhos de diretor, aproveitei o que o grupo tinha de orgânico e fiz marcas.

Perto da estréia teve o 11 de setembro, o tema do nosso espetáculo infantil - a Guerra estava solta no mundo -

Trouxemos as professoras com as crianças de terceira série do ensino fundamental, era muito importante saber se as crianças entenderiam, e nos surpreendemos, pois elas entenderam e decifraram todas as simbologias do texto, as professoras, porém, não entenderam.

A Sônia chorou na estréia, o último espetáculo fizemos na Casa do Ventoforte, num domingo pela manhã com muita chuva e um frio de rachar. O llo sentou com os meninos e disse que havia gostado, por termos usado cenas de vários espetáculos que vieram depois dele ter escrito Da Metade do Caminho... A imagem dele foi de um sonho, onde os espetáculos se misturavam, achou bom que tudo não era perfeito. Os meninos choraram muito, a maquiagem branca se encheu de rios de lágrimas."

(Fátima Campidelli)

O relato espontâneo de Fátima Campidelli possibilita novos elos para a história que aqui vem sendo desencadeada. Por exemplo: a função das pessoas no grupo, o processo criador do ator nos espetáculos, as dificuldades impostas ao ator por esse modo de fazer teatro e a constatação da mudança nos modos de produção após o final dos anos 80 .

Mas existem muitos outros elos possíveis, afetivos e da memória que se entrecruzam com outros que foram levantados. São experiências de vida e arte que se transformaram em teatro. Embora uma arte efêmera, fugaz, deixou marcas no tempo. 
A amostragem de depoimentos buscou, sobretudo, elementos que enriquecessem o entendimento de como ocorre a aprendizagem estética, qual a sua importância e como se desdobra, assim sendo não é qualitativa no sentido de que não temos o depoimento de todas as pessoas que trabalharam ou foram alunos dos cursos e oficinas. Os depoimentos buscam também compreender a amplitude da figura de llo Krugli que nos depoimentos sempre é lembrada como uma referência artística.

Dei os títulos aos depoimentos a partir de sua leitura e de palavras-chave que corroboravam com as idéias que vinham sendo levantadas até aqui. É importante frisar que os depoimentos vieram depois e que a pesquisa fundamentou-se na minha convivência e aprendizado e que tentei localizar todas as pessoas que aparecem nos depoimentos e nas fichas técnicas. Os relatos trazem sempre a afetividade em relação ao aprendizado ocorrido, são poucas as críticas em relação ao trabalho do grupo Ventoforte, que é visto como deflagrador da prática artística por quase todos os que passaram por ele e pelos que assistiram aos espetáculos.

Reconheço que poderia haver uma análise de como foi posta em prática, pelos ex-integrantes do grupo, a proposta de llo Krugli no ensino da Arte. Mas considero que os depoimentos seriam apenas o ponto de partida para essa investigação e acredito que não há possibilidades de realizá-la para esse trabalho. 


\section{Considerações Finais}

Adeus, adeus eu já vou me embora, eu vou com Deus e Nossa Senhora !! Adeus, adeus, adeus, adeus...

(Cantiga de Domínio Público) 
O Teatro Ventoforte foi considerado pela crítica especializada um marco, um divisor de águas, no teatro infantil brasileiro com a estréia de Histórias de Lenços e Ventos, sua proposta de encenação encontra paralelos e ressonâncias com movimentos artísticos que renovaram a educação artística e estética, no Brasil e na Europa. Sua trajetória relaciona-se à da história do ensino das artes plásticas e do teatro, influencia-se por este movimento e deságua em propostas articuladas de forma a integrar várias tendências

Nos seus 28 anos de trajetória, insere-se no contexto da contemporaneidade identificado a movimentos e idéias modernistas e no melhor devir dos ideais propostos por estes. O diretor llo Krugli e seu Ventoforte, mantém sua proposta de encenação.

Todas as cortinas foram abertas, atores e músicos ensolarados pela memória saem cantando, carregam bonecos, sonhos e saudades, o espetáculo termina. Eu, mestre de cerimônias, agradeço com profunda gratidão e respeito a todos os que fizeram essa história acontecer, que foram pedra, água, terra e fogo. Como diz José Celso Martinez, diretor do grupo Oficina, no programa de Os Sertões:

"A superação de ser esse ninguém chamado todo mundo pela possibilidade de ser todo mundo...pedra, rios chuvas, ventos, elementos que estão em todos nós" 90

Alice Gonçalves, Alice Reis, Alsonia Bernardes, Ana Beatriz Mesquita, Ana Lu Fernandes, Ana Luíza Frangipani, Ana Maria Carvalho, Ana Oliveira, Ana Van Steen, André Collazzi, Andrea Cavinato, Angela Cresta, Antônio Gomes, Armindo Rodrigues Pinto, Benê Castro Aleixo, Berenice Baeder, Biza Viana, Beto Coimbra,

${ }^{90}$ MARTINEZ, José Celso Correa. Os Sertões. Programa do espetáculo, 2002. 
Beto Andretta, Caíque Botkay, Claudio Cabrera, Cinthia Gusmão, Cissa Tucori (in memoria), Colemar Ferreira Nunes, Damilton Viana, Dinho Lima, Daniel Pereyra, David Tygel, Edilson Castanheira Eduardo Machado, Edgar Lippo, Eliane Weinfurther, Evandro Palma, Fábio Atorino, Fernando Cavalcanti, Fernando Gatti, Fátima Campidelli, Flávia Cunha, Giovanna Quaglia, Graziela Rodrigues, Ignes Carvalho, Ignez Perdião, Ilo Krugli, Isa Uehára, Isadora Dias Prates, Joana Pinheiro, João Poletto, João Maria Teixeira, José Carlos Machado, José Marcos Bueno, João Gomes, Gustavo Trestini, Jaqueline de Paula, Jaqueline Schein, Jorge Bóris, Jorge Odara (in memoria), Karu Basso, Laerte Arnis, Lauro Gastanãga, Loy de Andrade, Laurent Lucien Matari, Ligia Cavalcanti, Liliana lacooca, Ligia Catunda, Luri de Almeida, Luís Carlos Laranjeiras, Luís Figueiredo, Lena de Sá, Luciana Coin, Maicira Trevisan, Marcela Alves, Márcia Correa, Márcia Cabral, Márcia Fernandes, Marcos Coin, Marco Rovério, Marcus Vinicius (Peninha), Maria do Carmo Amaral, Marina Marcondes Machado, Mariana Muniz, Mariana Corollon, Marilde Belo, Marilda Alface, Marlon Chaves Feitosa, Marta Ozzeti, Mary Gelman, Ná Ozzetti, Nana Mattos, Neusa Navarro, Ocimar Barbosa, Osvaldo Gabrielli, Osmar Emídio, Ozair Lessa, Paco, Paulo Alexandre, Paulo César Brito, Paulo Farah André, Paulo da Rosa, Paulo Freire, Paulo Roberto de Souza Campos, Pedrão do Maranhão, Pedro Veras, Peterson Negreiros, Queca Vieira, Regina Costa, Regina Celi, Regina Arruda, Renata Alucci, Renato Anesi, Renato Vidal, Révero Ribeiro, Rita Coelho, Ricardo Nogueira, Rosa Comporte, Roberto Mello, Ronaldo Motta, Rui Weber, Selma Bustamante, Sérgio Fidalgo, Sérgio Habibe, Silvia Aderne, Silvia Heller, Sílvia Yuba, Sidney Cerchiaro, Silvio Correia Lima, Sonia Azevedo, Sonia Gato, Sonia Piccinin, Thaia Perez, Tatiana Bichara, Thelma Bonavita, Ted Rey, Teresa Freitas, Teresa Herling, Tião Carvalho, Tina Brunseck, Vanice Pozzeti, Xuxa Lopez, Wagner Bonnetti, Wilton Amorim, Wilker Soares, Zula Lemes, 
São pessoas que estão, passaram; e quem sabe? Ainda retornem ao Ventoforte. E, com seu trabalho pessoal, contribuiram para sua continuidade. Outras, cujos nomes foi impossível registrar também fazem parte dessa história.

Ao contar essa história, percebi que a aprendizagem estética necessita ser organizada e aprofundada teoricamente para tornar consciente a própria prática. A conquista dos alicerces para a construção do pensamento está presente em desvendar suas origens e os conceitos que a fundamentam.

$\mathrm{Na}$ aprendizagem no Ventoforte encontrei possibilidades, ordenação, e formas para o meu hábito de imaginar, que deixou de ser devaneio. Agora conquisto as palavras, tento ordenar minhas idéias e minhas imagens através delas; conquista valiosa, mesmo porque, foi desde muito cedo na minha vida, desejada.

Com meus pés diferentes inventei um caminho possível para mim, porque, se no Ventoforte reaprendi a andar, caminhei do Vento para a universidade e da universidade para o Vento, na lenta construção do reconhecimento do que era que eu tinha, na verdade, me apropriado.

Agora que estou conquistando as palavras registro uma experiência em Teatro e Educação para que outros também possam ter acesso a ela.

Embora o mistério inominável e imponderável esteja sempre presente, exercitei-me no caminho da pena: escrever. O resultado desse esforço é o registro de uma prática artística para crianças que espero possa, também, se tornar útil para ampliar discussões sobre o modo como é vista a infância e o ensino de arte a ela destinada. 
Não nascemos virtuosos, mas nos tornamos. Como? Pela educação e pelo amor. Pelo amor, tudo! Disse o rouxinol que cantava há mais de mil anos...

"A generosidade, essa virtude humana! Agir bem e manter-se alegre, o amor é a finalidade, a generosidade é o caminho" dizia Spinoza. De minha parte continuo a tentar ser aprendiz de feiticeiro...

Lembro-me de uma frase de Paulo Mendes Campos que aprendi na adolescência... "eu quero o Vento que passa, pois o Vento que passa traz a notícia do momento". E traz muitas outras coisas...

\author{
"O vento da madrugada \\ nunca chega só \\ numa mão traz o sol \\ na outra o beija flor, \\ ele é misterioso \\ mas não é medroso \\ já fez no ar \\ um gato, um rato \\ uma escada, um telhado \\ mas que vento guloso \\ ele não é medroso ele traz o sol, \\ ele traz o sol. " ${ }^{\prime 91}$
}

${ }_{91}$ Letra de llo Krugli Música de Caíque Botkay. 
Eu encerro, assim como iniciei, tomando emprestadas as palavras de Caíque Botkay, com relação a isso, a idéia "de indomável Ventoforte" que está no título dessa dissertação foi tomada do Caíque. Ele escreveu uma crítica na temporada no Rio de Janeiro do Teatro Cacilda Becker, em 1997, sobre o grupo Ventoforte, no jornal Vertentes intitulada: Ilo Krugli e seu indomável Ventoforte.

Quando eu disse que tinha tomado emprestada essa expressão inventada por ele, respondeu-me:

- É sua. Não é emprestada, é sua. Eu te dei...

A partir da conversa com Caíque Botkai, considero que, apesar de inicialmente não ser meu objetivo de pesquisa entrevistar os integrantes fundadores do Ventoforte que ficaram no Rio de Janeiro, concluo que o trabalho teria sido diferente se meu contato, as entrevistas e depoimentos dele e de Beto Coimbra, Ronaldo Motta e Silvia Aderne, tivessem acontecido antes para que houvesse mais tempo de serem aprofundadas.

Espero que esse trabalho contribua para a reflexão sobre a obra de llo Krugli como um todo. Meu desdobramento do aprendizado foi concretizado para que cada vez mais ela se torne conhecida, que sua prática artística voltada para a virtude possa inspirar outras práticas. 


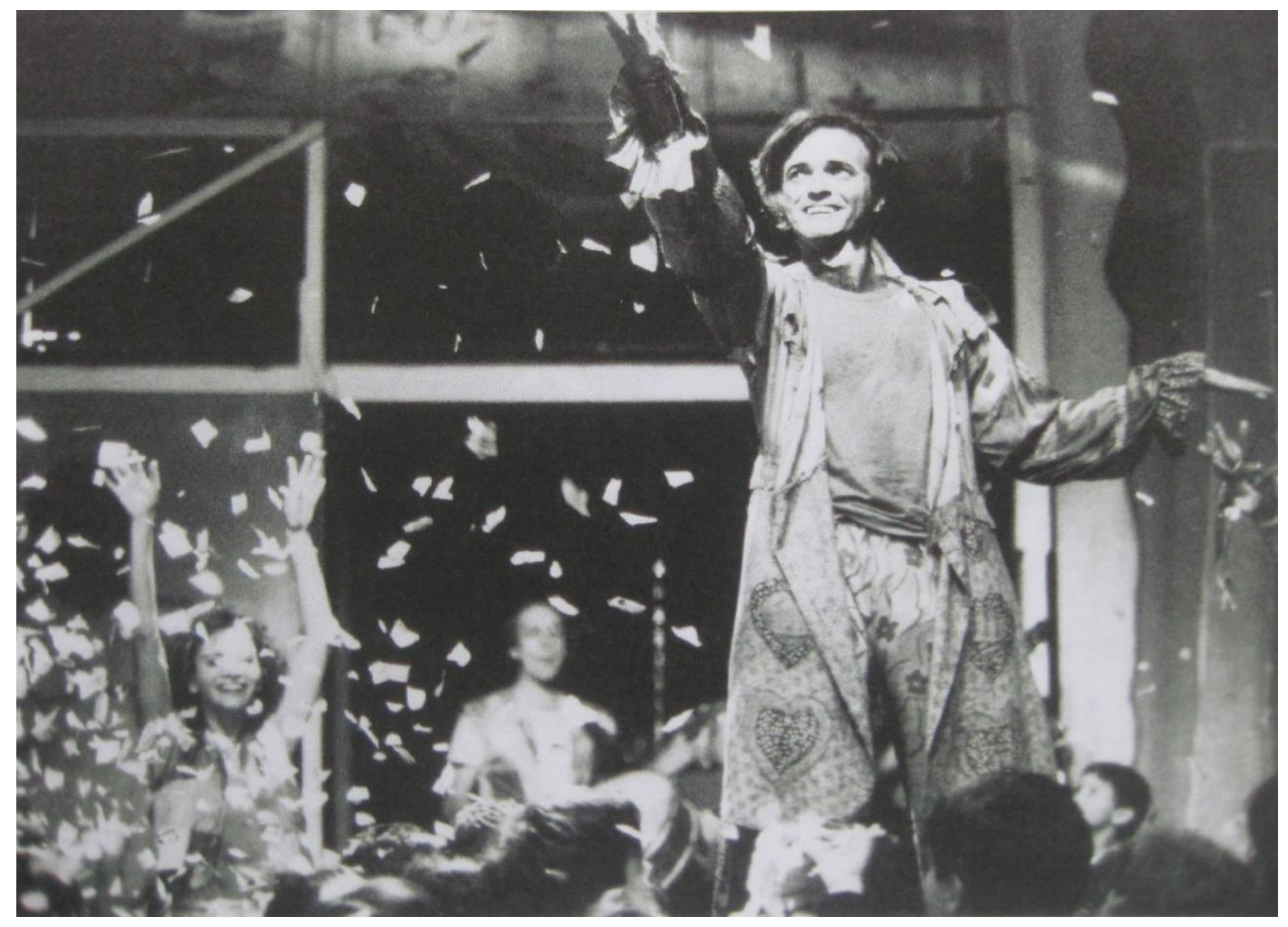




\section{Bibliografia}

AMARAL, Ana Maria. Teatro de bonecos no Brasil e em São Paulo de 1940 a 1980. São Paulo: ComArte, 1994.

Teatro de formas animadas. São Paulo: Edusp, 1993.

ALBANO, A. A. Moreira. O espaço do desenho e a educação do educador. Editora Loyola, São Paulo, 1991.

ALMEIDA, R. Inteligência do folclore. Rio de Janeiro: Editora Americana, 1974.

ALVES, Rubem. Conversas com quem gosta de ensinar. São Paulo: Cortez e Editores Associados, 1987.

A escola com que sempre sonhei sem imaginar que pudesse existir. Porto: Edições Asa, 2001.

ARIÈS, Philipe. História social da família e da criança. Rio de Janeiro: Guanabara, 1981.

ARNHEIM, Rudolf. Intuição e intelecto na Arte. São Paulo: Martins Fontes, 1989. - Thoughts on Art education. United States of America: The Getty Center of Education in the Arts, 1991.

BACHELARD, Gaston. A poética do espaço. São Paulo: Martins Fontes, 1988. A água e os sonhos: Ensaios sobre a Imaginação da 
matéria. São Paulo: Martins Fontes, 1994.

. O ar e os sonhos. São Paulo: Martins Fontes, 1994.

BARBOSA, Ana Mae. Teoria e prática da Educação Artística. São Paulo: Editora Cultrix, 1985.

Arte-educação: leitura no subsolo. São Paulo: Cortez: 1991.

- Arte-Educação no Brasil: das origens ao modernismo. São

Paulo: Editora Perspectiva, 1978.

- Recorte e colagem : influências de John Dewey no ensino de arte no Brasil. São Paulo: Cortez, 1982.

Arte-educação: conflitos e acertos. São Paulo: Editora Max Limonad, 1984.

- (Org.). História da Arte-Educação: A experiência de Brasília. São Paulo: Editora Max Limonad, 1986.

. A imagem do ensino da Arte no Brasil. São Paulo:

Perspectiva, 1986.

BETTELLHEIM, Bruno. A psicanálise dos contos de fadas. São Paulo: Paz e Terra, 1978.

BELINKI, Tatiana e outros. Produção cultural para a criança. Porto Alegre: Mercado Aberto, 1982. 
BENJAMIM, Walter. Reflexões sobre a criança, o brinquedo e a educação. São Paulo: Duas Cidades Editora 34, Coleção Espírito crítico, 2002.

- Magia e técnica. Arte e política. São Paulo: Editora Brasiliense, 1985.

BOJUNGA, Ligia. Livro. Rio de Janeiro: Agir, 1988.

BORBA FILHO, Hermilo. Fisionomia e espírito do mamulengo. São Paulo: Edusp. 1966.

BOSI, Alfredo. Reflexões sobre a Arte. São Paulo: Editora Ática, 1989.

O ser e o tempo da poesia. São Paulo: Editora Cultrix, 1977.

Cultura brasileira: temas e situações. São Paulo: Editora Ática, 1991.

BOSI, Ecléa. Memória e sociedade: Lembranças de velhos. São Paulo: Editora Companhia das Letras, 1994.

BOTKAI, Caíque. Achados. Rio de Janeiro: Editora Nova Fronteira, 2002.

BROOK, Peter. O teatro e seu espaço. Rio de Janeiro: 1970.

CALVINO, Ítalo. Seis propostas para o próximo milênio. São Paulo: Companhia das Letras, 1990.

CASSIRER, Ernst. Linguagem e Mito: Uma contribuição ao problema do nome dos deuses. Editora Perspectiva, São Paulo, 1972.

CHACRA, Sandra. Natureza e sentido da improvisação teatral. São Paulo: 
Editora Perspectiva, 1983.

CHAUÍ, Marilena. Seminários. São Paulo: Editora Brasiliense, 1983.

COURTNEY, R. Jogo, teatro e pensamento. São Paulo: Editora Perspectiva, 1980.

DEWEY, John. A arte como experiência. São Paulo: Abril Cultural, 1985.

Vida e educação. São Paulo: Editora Nacional, 1959.

DORT, Bernard. O teatro e sua realidade. São Paulo: Editora Perspectiva, 1983.

DUMAZEDIER, J. Lazer e cultura popular. São Paulo: Editora Perspectiva, 1976.

DURAND, Gilbert. $\underline{\mathrm{O} \text { imaginário. Ensaio acerca das ciências e da }}$ filosofia da imagem. 2eedição. Rio de Janeiro: Editora Difel, 2001.

- Estruturas antropológicas do imaginário. São Paulo: Editora Martins Fontes, 1997.

ECO, Umberto. Seis passeios pelos bosques da ficção. São Paulo: Companhia das Letras, 1994.

EFLAND, Arthur D. A history of Art Education. Intellectual and social currents in teaching the Visual Arts. New York, Teacher College Press: Columbia University, 1990.

FELDMAN, E. B. Becoming human through art. N. Jesrey: Prentice-Hall, Englewood Cliffs, 1970.

FELíCIO, Vera Lúcia G. A imaginação simbólica nos quatro elementos bachelar- 
dianos. São Paulo: Ensaios de Cultura, vol. 5, EDUSP, 1994.

FERNANDES, Silvia. Memória e invenção. Gerald Thomas em cena. São Paulo: Editora Perspectiva, 1996.

. Grupos teatrais dos anos 70. Campinas: Unicamp, 2000.

FISCHER, Ernest. A necessidade da Arte. Rio de Janeiro: Zahar Editora, 1976.

FOUCAULT, Michel. Vigiar e punir. Petrópolis: Editora Vozes, 1979.

FORDHAM, Frieda. Introdução à psicologia de Jung. São Paulo: Verbo, Editora da Universidade de São Paulo, 1978.

FUSARI, Maria F. R. e FERRAZ, Maria Heloisa C. Arte na educação escolar. São Paulo: Cortez Editora, 1993.

FUSARI, Maria F. R. e FERRAZ, Maria Heloisa C. Arte na educação escolar. São Paulo: Cortez Editora, 1993. Apud Thomas Munro, ArtEducatio Its Philosophy na Psychology. Nova York: The Liberal Arts Press, 1956.

FREIRE, Paulo. Pedagogia do Oprimido. Rio de Janeiro: Editora Paz e Terra, 1983.

- Educação como prática de liberdade. Rio de Janeiro: Editora Paz e Terra, 1983. 
GUERRA, Marco Antônio. Carlos Queiróz Telles. História e Dramaturgia em Cena (Década de 70). São Paulo: AnnaBlume Editora,1993.

GUINSBURG, Jacó; COELHO NETO, José Teixeira; CARDOSO, Reni Chaves. (Org.). Semiologia do teatro. São Paulo: Editora Perspectiva, 1978.

HOLLANDA, Heloísa Buarque de. Impressões de viagem: CPC, vanguarda e desbunde - 1960/1970. São Paulo: Editora Brasiliense, 1981.

HELD, Jaqueline. O imaginário no poder: as crianças e a literatura fantástica. São Paulo: Summus Editora, 1985.

HUIZINGA, Johan. Homo ludens. O jogo como elemento da cultura. São Paulo: Editora Perspectiva, 2001.

JUNG, C. G. O homem e seus símbolos. Rio de Janeiro: Editora Nova Fronteira, 1985.

- Memórias, sonhos e reflexões. Rio de Janeiro: Editora Nova Fronteira, 1975.

. Psicologia do inconsciente. Petrópolis: Editora Vozes, 1978.

KENSKI, Vani Moreira. Sobre o conceito de memória. In: A pesquisa em educação e as transformações do conhecimento. FAZENDA, Ivani (Org.). Campinas: Papirus Editora.

KOUDELA, Ingrid. Jogos teatrais. São Paulo: Ed. Perspectiva, 1995. 
- Brecht: um jogo de aprendizagem. São Paulo: Editora Perspectiva, 1991.

KRUGLI, Ilo. História de Lenços e Ventos. Rio de Janeiro: Editora Didática e Científica, 2000.

LA TAILLE, Yves de; OLIVEIRA, Marta Kohl de; DANTAS, Heloísa. Piaget, Vigotsky e Wallon: Teorias psicogenéticas em discussão. São Paulo: Summus Editorial, 1992.

LANGER, Susanne. Filosofia em Nova Chave. Um estudo do simbolismo da Razão, Rito e Arte. São Paulo: Editora Perspectiva, 1971.

. Ensaios filosóficos. São Paulo: Editora Cultrix, 1971.

. Sentimento e forma. São Paulo: Editora Perspectiva, 1979.

LÉVI-STRAUSS, Claude. Antropologia estrutural. Tempo Brasileiro, Rio de Janeiro, 1967.

. O pensamento selvagem. São Paulo: Editora Nacional, 1976.

LORCA, F. Garcia. Romanceiro Gitano. Rio de Janeiro: Editora Nova Fronteira, 1985.

- Assim que passarem cinco anos. Lenda do Tempo. Brasília:

Editora da Universidade de Brasília; São Paulo: Imprensa Oficial do Estado, 2000.

LORCA, F. Garcia. Conferências. Brasília: Editora Universidade de Brasília; 
São Paulo: Imprensa Oficial do Estado, 2000.

LOPES, Joana. Pega teatro. São Paulo: Centro de Teatro e Educação Popular, 1981.

LOWENFELD, Viktor; BRITTAIN, W. L. Desenvolvimento da capacidade criadora. São Paulo: Editora Mestre Jou, 1977.

MEDINA, Pablo. Javier Villafañe. Antologia. Obras y recopilaciones. Buenos Aires: Editorial Sudamericana, 1990.

MOSTAÇO, Edélcio. Teatro e política: Arena, Oficina e Opinião. São Paulo: Proposta Editorial, 1982.

MORAES, Marina Célia Dias de. Metáfora e pensamento: considerações sobre a importância do jogo na aquisição do conhecimento e implicações para a educação pré-escolar. In: HISHIMOTO, T. (Org.). Jogo, brinquedo, brincadeira e a educação. São Paulo: Cortez Editora.

MOURISSIER, François. Federico Garcia Lorca Dramaturgue. Paris: L'Arche Éditeur, 1955.

OAKLANDER, V. Descobrindo crianças: abordagem gestáltica com crianças e adolescentes. São Paulo: Summus Editorial, 1980.

OLIVEIRA, Marta Kohl de. Vygotsky: Aprendizado e desenvolvimento, um processo sócio-histórico. São Paulo: Editora Scipione, 1995.

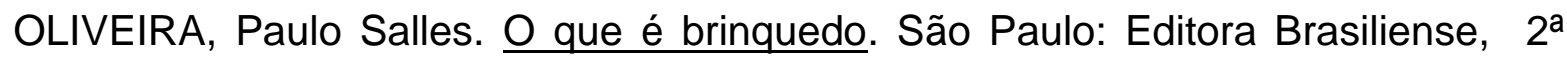
ed, 1989.

ORTEGA Y GASSET, José. A idéia do teatro. São Paulo: Perspectiva/ 
Secretaria de Cultura, Ciência e Tecnologia do Estado de São Paulo, 1978.

OSSONA, Paulina. A educação pela dança. São Paulo: Summus Editorial, 1988.

OSTROWER, Fayga. Criatividade e processos de criação. Petrópolis: Editora Vozes, 1984.

PALLOTTINI, Renata. Introdução à dramaturgia. São Paulo: Editora Ática, 1988.

PAVIS, Patrice. Dicionário de Teatro. São Paulo: Editora Perspectiva, 1999.

PIAGET, Jean. A psicologia da criança. São Paulo: Riefel Saber Atual, 1974.

. A formação do símbolo na criança. Rio de Janeiro: Jorge Zahar Editor, 1971.

PIRAGIBE, Mário. (2001) Um percurso do teatro de animação através da experiência de llo Krugli. (http://www.cbtij.org.b.htm).

PUPO, Maria Lúcia de S. B. No reino da diversidade. São Paulo: Editora Perspectiva, 1985

READ, Herbert. A educação pela Arte. Lisboa: Edições 70, 1982.

- A redenção do robô: meu encontro com a educação através da Arte. São Paulo: Summus Editorial, 1986.

RILKE, Rainer Maria. Cartas a um jovem poeta e A canção de amor e de morte do porta-estandarte. Cristóvão Rilke. São Paulo: Editora Globo, 2001.

RODRIGUES, Augusto (Coord.). Escolinha de Arte do Brasil. Brasília: EAB, 1980. 


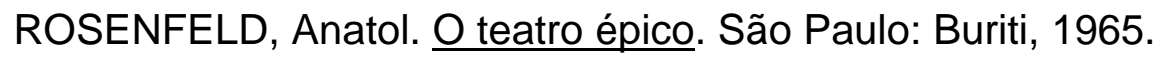

ROUBINE, Jean-Jacques. A linguagem da encenação teatral. Rio de Janeiro: Jorge Zahar Editora, 1998.

. A Arte do ator. Rio de Janeiro: Jorge Zahar Editor, 1995.

RYNGAERT, Jean-Pierre. Introdução à análise do teatro. São Paulo: Martins Fontes, 1996.

SCHLEMMER, Oskar. Theatre of the Bauhaus. (Ed. e introdução de W. Gropius, tradução de A. S. Weisinger). Midletown: Wesleyan University Press, 1961.

SEVERINO, Antonio Joaquim. Metodologia do trabalho científico. São Paulo: Cortez Editora, 2002.

SILVEIRA, Nise da. O Mundo das imagens. São Paulo: Editora Ática, 1992.

. Imagens do inconsciente. Rio de Janeiro: Editora Alhambra, 1981.

Jung, vida e obra. Rio de Janeiro: José Álvaro Editor, 1977.

Casa das Palmeiras: A emoção de lidar. Uma experiência em Psiquiatria. Rio de Janeiro: Ed. Alhambra, 1986.

SLADE, Peter. O jogo dramático infantil. São Paulo: Summus Editorial, 1978.

SPONVILE, André Conté. Pequeno tratado das grandes virtudes. São Paulo: Martins Fontes, 1996. 
VÁSQUEZ, Adolfo Sanches. Filosofia da práxis. Rio de Janeiro: Editora Paz e Terra, $2^{\circ} \mathrm{Ed}, 1997$.

VIGOTSKY, L. S. A formação social da mente. São Paulo: Martins Fontes, 1988.

Pensamento e linguagem. São Paulo: Martins Fontes, 1987.

. La imaginación y el arte en la infancia: Ensayo Psicológico. Madrid: Ediciones Akal, 1990.

VILLAFAÑE, Javier. Títeres de la Andariega. Buenos Aires: Ediciones Colihue, 1990.

Cuentos con pájaros. Buenos Aires: Libraria Hachete, 1978.

WEKWERTH, Manfred. Diálogo sobre a encenação: Um manual de direção teatral. São Paulo: Editora Hucitec, 1997.

WINICOTT, D. W. $\underline{O}$ ambiente e os processos de maturação: estudos sobre 0 desenvolvimento emocional. Porto Alegre: Artes Médicas, 1983.

O brincar e a realidade. Rio de Janeiro: Editora Imago, 1975.

ZILBERMAN, Regina (Org.). A produção cultural para a criança. Porto Alegre: Editora Mercado Aberto, 1990.

Dissertações, teses e não-publicados:

ALVES, Amara Chagas. A brincadeira prometida... O jogo teatral e os folhetos populares. Dissertação de mestrado da ECA/USP: São Paulo, 1992. 
AZEVEDO, Fernando Antonio G. de. Movimento das Escolinhas de Arte: em cena memórias de Noêmia Varella e Ana Mae Barbosa. São Paulo, Tese de mestrado, ECA/USP, 2001.

CAVINATO, Andrea. Ventoforte: de Histórias de Lenços e Ventos ao Príncipe Feliz, sua trajetória de construção de uma linguagem teatral. Entrevista de llo Krugli concedida em 1993. São Paulo, TCC, Faculdade de Medicina, TO/USP, 1994.

CASTRO, Ilíada Silva Alves. A dramaturgia no teatro para crianças em São Paulo - Uma análise de textos premiados. Tese de Mestrado ECA/USP, 1987.

COSTA, Sabino. A dramaturgia nos grupos alternativos no período de 1975 a 1985. Tese ECA/USP, s. d.

CURRICULUM VITAE ILO KRUGLI. Arquivo Ventoforte.

FIGUEIREDO, Luís Fernando. Ventoforte: O teatro de imagens fantásticas. Não publicado. Relatório de Bolsa de iniciação científica CEPE, 1993.

GRANERO, Maria Victória V. M. A aventura do teatro na Bauhaus. Tese de doutorado apresentada à ECA/USP, São Paulo, 1995.

MACHADO, Regina. Arte-educação e o conto de tradição oral: elementos para uma pedagogia do imaginário. Doutorado ECA/CAP/USP, São Paulo, 1989.

NOGUEIRA, Márcia Pompeu. Teatro com meninos de rua. São Paulo, Dissertação de mestrado. ECA/USP, 1993. 
PUPO, Maria Lúcia S. B. Palavras em jogo: textos literários e teatro-educação. 1997. Tese de livre docência. ECA/USP, São Paulo.

VENTOFORTE. Projeto Vento 87 Teatro para todos. Museu da Arte e Liberdade de Expressão da Criança. Mimeo. 1987, Arquivo Ventoforte.

\section{Artigos em revistas e periódicos}

CANDIDO, Antonio. A Literatura em 1972. Arte em Revista no 1, São Paulo, Kairós Livraria e Editora, jan./mar. 1979.

GODOY, Carlos Ernesto de. Um brinquedo: Simples mas sem fórmula. Rio de Janeiro: Visão ano X no 22, 7-7-80.

KRUGLI, Ilo. Um panorama do teatro jovem no Brasil. In. Revista O Teatro Jovem, Rio de Janeiro: Brito Produções, maio 1998, pág. 12.

Arte nas Escolas. In. Revista E, São Paulo: SESC, Através da Arte propõe-se reconstruir uma arquitetura social, ética e sobretudo estética. Publicação Mensal, № 01, Ano 3, julho, 1996, p. 33-34.

PUPO, Maria Lúcia S. B. "Além das dicotomias". In: Anais do Seminário nacional de arte e educação: Educação emancipatória e processos de inclusão sociocultural. Fundação Municipal de Artes de Montenegro, RS: Fundarte, 2001.

. "Fronteiras etárias no teatro: da demarcação à abertura". Revista da USP, dez./fev. 1999-2000, p. 335-341.

VARELA, Noêmia. Movimento Escolinhas de Arte. Revista Fazendo Artes, Rio de Janeiro, no 13, p. 2-7, 1988. In: Jornal Arte\&Educação, Rio de Janeiro, Edição Especial em comemoração aos 50 anos da 
Escolinha de Arte do Brasil. Fevereiro de 1999.

\section{Críticas e artigos em jornais}

ALMEIDA, Lívia. "...sinto que muita gente não sabe se me coloca em um pedestal, no museu ou se me joga no ostracismo". Rio de Janeiro: Jornal Vertente, voltado à produção cultural para a criança e o adolescente, Ano I, № 2, fev. 1997, p. 10-11.

BELINKI, Tatiana. Lenços ao sopro do Ventoforte. São Paulo, Folha de S. Paulo, 13/7/1980.

. Um poema para Lorca. São Paulo: O Estado de S. Paulo, Caderno 2, 13-12-1986.

BERNASCONI, Roberto. II vento, i bambini, la speranza. Lugano: Libera Stampa, Quotidiano Del Partito Socialista Ticinese, 9 jun. 1981.

BOTKAY, Caíque. lo Krugli e seu indomável Ventoforte. Rio de Janeiro: Jornal Vertente, voltado à produção cultural para a criança e o adolescente, Ano I, no 2, fev. 1997, p. 11.

CAMARGO, Robson. Barquinho movido a pura poesia. São Paulo: Folha de São Paulo, llustrada, 5-10-1984.

Sonhos e mistérios do mundo infantil. São Paulo: Folha de S. Paulo, llustrada, 14-12-85.

FILHO, Antônio Gonçalves. História de llo, o menino navegador. São Paulo: Folha de S. Paulo, llustrada, 2-10-81.

FUSER, Fausto. A tempestade traz bons ares ao Ventoforte. São Paulo: Diário 
Popular, sábado, 2-12-1989, pág. 3.

GARCIA, Clóvis. A força do mamulengo aliada ao jogo teatral. São Paulo: O Estado de S. Paulo, 23-7-1979.

Uma brincadeira para as crianças. E os adultos não resistem. São Paulo, Jornal da Tarde, 30-7-1983.

Um barquinho viajando em ritmo preciso. São Paulo: O Estado de S. Paulo, Infantil/Crítica, 7 nov. 1981.

. Ventoforte, rico e irresistível. São Paulo: Jornal da Tarde, Divirtase, $12-4-86$.

. Lorca, para crianças (e adultos). Em favor da liberdade. São Paulo, O Estado de S. Paulo, Jornal da Tarde, 28-03-87.

. Os jogos infantis, num espetáculo eficiente. $\mathrm{E}$ de muita beleza. São Paulo: O Estado de S. Paulo, Jornal da Tarde, 29-10-83.

. Nesta peça, diversão. E seriedade. São Paulo: O Estado de S. Paulo, Jornal da Tarde, 8-11-1980.

. No palco, cantos e jogos infantis. São Paulo: O Estado de S. Paulo, Jornal da Tarde, 18-04-1981.

LOPEZ, Rui Fontana. "Lenços e Ventos", jogos que derrotam a tirania. São Paulo: O Estado de S. Paulo, 17-1-1981.

MACHADO, Ana Maria. Novos prêmios para teatro infantil. Rio de Janeiro, Jornal do Brasil, 1977.

MAGALDI, Sábato. Um grande espetáculo feito de coisinhas. São Paulo, O 
Estado de S. Paulo, 1977.

MICHALSKI, Yan. Pequenas Histórias. Grande Espetáculo. Rio de Janeiro, Jornal do Brasil, 1976.

NETO, Dib Carneiro. Ventoforte faz 20 anos e monta Oscar Wilde. São Paulo: O Estado de S. Paulo, Caderno 2, no 2713, 14-7-1994.

Ventoforte está mais poético do que nunca. São Paulo: Estado de S. Paulo ${ }_{2}$ Caderno 2 (Guia), 28-7-1994.

\section{Entrevistas}

BÓRIS, Jorge. Entrevista concedida por telefone a Andrea Cavinato, em janeiro de 2003.

BRITO, Paulo César. Entrevista concedida por telefone a Andrea Cavinato, em janeiro de 2003.

CARVALHO, Tião. Entrevista concedida a Andrea Cavinato, em janeiro de 2003.

CATUNDA, Lígia. Entrevista concedida a Andrea Cavinato, em janeiro de 2003.

COMPORTE, Rosa. Entrevista concedida a Andrea Cavinato, em janeiro de 2003.

KRUGLI, Ilo. Entrevista concedida a Andrea Cavinato, em outubro de 1994.

. Entrevista concedida a Andrea Cavinato, em 
dezembro/janeiro de 2002/2003.

GABRIELLI, Oswaldo. Entrevista concedida por telefone a Andrea Cavinato, em janeiro de 2001.

ROSA, Paulo da. Entrevista concedida a Andrea Cavinato, em outubro de 1994.

\section{Roteiros}

KRUGLI, Ilo. Histórias que o eco canta. Manuscrito, 1995. O mistério do fundo do pote. São Paulo, 1992, mimeo.

\section{Documentação fotográfica e textual}

Festival Internacional de Londrina. Mostra internacional. Catálogo, 1997.

SESC Carmo. Festival de Teatro de Rua. Programa, 1993.

SESC. Festival Internacional de animação. Programa. 1994.

SESI. Folheto da $1^{\text {a}}$ Mostra de Teatro Infantil. São Paulo, 2002.

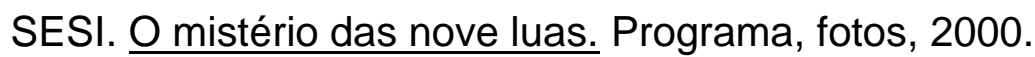

VENTOFORTE. As Pequenas Histórias de Lorca. Programa, 1976. Catálogo dos 10 anos do Ventoforte. 1984. Choro Lorca. Programa do espetáculo, São Paulo, 1986. 
O círculo de giz caucasiano. Programa, cartaz, 1996.

. Feira de Teatro. 28 anos. Programa, 2002.

. História de Fuga, Paixão e Fogo. Programa, 1982.

. Labirinto de Januário. Programa, 1984.

A Tempestade ou O Punhal de Caliban. Programa, 1989.

. Tragicomédia da Lua Branca. Programa, cartaz, fotos, 1995.

Histórias que o eco canta. Programa, fotos, cartaz, video, 1995.

. Sete corações poesia rasgada. Programa, fotos, cartaz, video, 1997.

. As quatro chaves. Programa, fotos, 1993.

. Portal das maravilhas. Programa, cartaz, fotos, 2001.

. O rio que vem de longe. Programa, cartaz, 1999.

- Seminário de Celebração dos 15 anos do Teatro Ventoforte. "As quatro idades". Prêmio Tempo. Folheto, cartaz, 1989.

. Minueto do final do século. Programa, 1994. 
Anexos 


\section{Tião Carvalho e a tradição popular}

Tião Carvalho é cantor, dançarino e fundador do grupo Cupuaçu de Danças Populares, integrou a equipe do grupo Ventoforte e foi professor dos cursos. Nasceu em Curupuru, no interior do Maranhão, e descende de uma família tradicional de artistas populares. O pai foi cantador, poeta popular.

"Pessoa muito esperta no uso da rima que se chama de cordel, mas lá no Maranhão é um pouco diferente, uso essa mesma forma de fazer poesia, mas é feita através dos tambores."

Em seu depoimento, registrado com o uso do gravador, Tião conta sobre sua formação em São Luís, onde foi morar com 8 anos de idade, onde participou de escola de samba, bumba-meu-boi e capoeira, e da importância do encontro com o Ventoforte.

"Eu diria que tem três pontos importantes na minha vida nesse decorrer do tempo: primeiro, esse lado familiar; depois a capoeira, a capoeira me ampliou bastante, meu mestre era músico também, então ele era muito próximo de outros músicos, então isso fez com que eu fosse me ampliar também, ter uma sustância ali e me entender um pouco; e o terceiro é quando eu saí do Maranhão, já com meus 24 anos, que eu saí com o Ventoforte, saí para trabalhar com o Ventoforte."

Tião conheceu o grupo em 1979, no Festival de Teatro de Bonecos de Ouro Preto, onde se apresentava com o grupo Laborart, do Maranhão.

"Quando eu vim para o Festival de Teatro de Ouro Preto, eu conheci o grupo Ventoforte. Nessa época eles apresentavam Sonho de um coração brejeiro naufragado de ilusão, que era um texto do Ernesto Albuquerque, um escritor pernambucano. Ganhou prêmio da ABTB, chamaram o llo para dirigir, ele levou o elenco dele para montar esse espetáculo e conheci assim o grupo, que tinha dois maranhenses na época, que era o Ronaldo Mota e a Júlia Emília.

A gente tinha o hábito de tocar, e aí que tinha o grande fascínio, eu já tinha essa coisa comigo desse cantor popular, do artista popular, tinha Ronaldo Mota, o 
Teo, que era um sanfoneiro que fazia parte do espetáculo, o Damilton Viana, percussionista, essas pessoas se encontraram e começavam a fazer festa e as outras pessoas do festival UHHH!!! Em cima. Porque a gente chegava no lugar, fazia, ia para a praça, tinha o Brás, mestre de Lua, que trabalhava no Ventoforte também, que era mestre de capoeira, angoleiro. E a gente tocava, fazia festa, ia para um bar, ficava a noite tocando, fazendo coisas para as pessoas dançarem. A gente fala mais da gente, mas o Paulo César, a Sonia Piccinin, a Márcia, todo o elenco, Lu e o pessoal do Laborart. Maranhenses se encontrando ali, mineiro, paulista, uma festividade.

Quando eles foram viajar para o exterior, no mesmo ano eles disseram: 'pô, nós vamos precisar de um percussionista'. Não teve outra dúvida, precisavam de um cara, podia chamar o Tião. Eu estava no Maranhão, eles me escreveram: 'a gente vai fazer uma viagem internacional'.

E o Ventoforte foi que me trouxe para a cidade grande e me deu espaço para eu também colocar minha linguagem, não chegava a ser uma carência, mas - Ventoforte tinha essa receptividade, que para mim era um pouco assim...novidade. Porque o llo, llo Krugli, argentino, morando no Brasil, dirigindo teatro no Brasil e com essa paixão pela cultura brasileira que ele tem, esse conhecimento que ele tem, paixão pelo Brasil, para mim foi uma coisa fascinante, apaixonante, que bom que houve essa empatia aí."

\section{Sem o llo, Isadora não seria Isadora}

"Minha trajetória de formação e complementação: passei pela faculdade Anhembi, USP com Marta Vestin (Estocolmo), Bolsa do CCFD da França, Teatro Vento Forte com Ilo Krugli, Mariana Muniz (dança), Grotowski (seminários e workshops). Eugenio Barba (seminários e workshops).

Escolhi o Ventoforte para estagiar tanto no teatro como na arte-educação. Pois já conhecia o trabalho do llo, como público e como aluna, em 1985. Acabei 
permanecendo no Vento de 87 a 90. Durante esse período, fui assistente do llo e professora, tanto no curso de formação para adultos e no curso para crianças e adolescentes, nos projetos com a prefeitura e Secretaria do Menor do Estado de São Paulo, como na direção das peças Histórias de lenços e ventos, do Ilo, $O$ Pássaro de Ouro ou Os Dois Irmãos, dos irmãos Grimm, A Tempestade, de Shakespeare. E eu e o Paulinho dirigimos o llo na peça Um Rio que vem de Longe, texto do Ilo. Foram anos muito frutíferos porque o llo estava fazendo, naquele momento, uma reflexão sobre o processo do ator e as fronteiras do teatro adulto e o infanto-juvenil, e o que ele chama de teatro para todos.

Foi imprescindível para a compreensão e apreensão do meu próprio processo, inevitável e insistente.

No sentido de que ampliou o meu universo de compreensão em relação ao teatro como um todo. E o carinho e a profundidade com que llo pensa a questão das idades (quatro idades do ser humano) e a arte-educação é simplesmente contagiante e enriquecedor.

Como localidade, espaço-tempo de apreensão de si mesmo no cosmo. Apreensão essa que nos leva à constante viagem do interno ao externo e viceversa. É assim quase impossível. Tínhamos períodos de improvisações e aquilo que chamo de reflexão sobre a improvisação. Durante os ensaios, eu desenhava e escrevia todo $o$ ensaio $e$ as mais fortes imagens e acontecimentos. Todo $o$ trabalho de voz e movimento partia do próprio ator.

Acho que tem um pouco dessa síntese na resposta anterior. Mas, nos ensaios usávamos a seguinte forma: com música, fazíamos aquecimento e alongamento - aquecimento e exercícios de voz. Improvisação, montagem de uma. Paralelamente, num horário diferente, leitura e reflexão sobre o texto. 
O objetivo dos cursos do Vento sempre foi a criação, a invenção e a vivência dos processos.

O meu pensamento sobre teatro e a arte como um todo mudou. Tenho o llo como uma jóia preciosa dentro do meu coração. Sem o llo, Isadora não seria a Isadora de hoje."

(Isadora Dias tem 48 anos, diretora de teatro e arte-educadora)

\section{Ronaldo Mota e o início no Rio de Janeiro.}

"Autodidatismo em música. Criador, desde a infância (mais ou menos 12 anos), de canções populares, vendo e escutando compositores e cantores em São Luís do Maranhão. Aprendi muito escutando minha mãe (cantora) que, desde cedo, informalmente, apresentou-me vasto repertório musical. O teatro musicado foi o próximo lugar de fazer e aprender.

Encontrei o Ventoforte no final da década de 70. Entrei no grupo para substituir um músico-ator no espetáculo Pequenas Estórias de Garcia Lorca. Fiquei quatro anos seguidos no grupo, trabalhando em cena como músico e ator. Nesse período, criei as músicas originais, trilhas e fazia a direção musical dos espetáculos O mistério das nove luas, Sonhos de um Coração Brejeiro, A História de um Barquinho - Esse Menino Navegador e Pequenos Bonecos que Movimentam o Mundo. 
No Ventoforte aprendi, antes de tudo com llo, a perceber e aprofundar a relação Artes Plásticas-Música-Dramaturgia. Nesse trinômio llo é mestre e, através de seu extremo processo de exercícios e "provocações", marcou indelevelmente todos que trabalharam com ele.

Pude desenvolver minha música dentro de um universo poético de extrema criatividade entre o texto da arte chamada erudita (Lorca, Ítalo Calvino, o próprio Ilo Krugli - o autor, diretor e cenógrafo) e a arte popular das ruas da América do Sul.

Meu processo de criação sempre esteve na linha de passagem que estabelecemos, sem formalizações entre texto, espaço cênico, movimento corporal e sonoridade. A parceria foi sempre "anárquica". Um gesto virava música. Uma cor que se movimentava sugeria um som, um timbre, um instrumento. Um pedaço de papel com versos feitos por llo, por mim ou ambos, já era uma nova música do espetáculo. Sempre fizemos muito rápido essas conexões.

Tudo isso eu levei muito para meus shows de música como solista, até hoje. A forma sugerida através do movimento plástico-musical. A brincadeira e o terreno lúdico comandando a ação e a apresentação. 
Uma coisa inestimável para mim. Uma coisa sem numeração é o que posso dizer ter herdado na minha passagem pelo Ventoforte, que me fez voltar, mesmo já sem pertencer formalmente ao grupo, e continuar desenvolvendo (largando tudo) outros espetáculos pelo tempo afora: Choro Lorca, Um rio que veio de longe e $\mathrm{O}$ mistério do fundo do pote, entre outras apresentações nos anos 80 e 90."

(Ronaldo Mota. Sou aquilo que se convencionou chamar de músico-ator no teatro. Sou também compositor e cantor de música popular)

\section{Roteiro para depoimento: Luiz Carlos Laranjeiras}

\section{Síntese da sua formação em Arte, sua trajetória de aprendizagem.}

Nasci ator, artista e, para mim, a vida sem a Arte seria um erro. Sou do Rio de Janeiro, das Laranjeiras, criado no Morro do Pasmado, em Botafogo, e aos nove anos encarei o palco pela primeira vez, para encenar um drama doméstico escrito por mim, chamado Ele vai nascer. A primeira imagem da minha vida teatral como ator e autor foi uma representação alegórica da fome: uma criança nasce, mas o peito da mãe é seco, não tem uma gota de leite. Nasci no Dia de Reis e minha vó Caçula, matriarca de 13 filhos, todo ano fazia festa em casa para receber a Folia de Reis do Mestre Pinga-Fogo. No fundo do terreiro, ela comandava um centro de umbanda em que os tambores e os caboclos viravam as madrugadas no chão de areia enquanto eu dormia atrás do altar. No carnaval, eu descia o morro para ensaiar na escola de samba do Pasmado. Fui um garoto magricelo, fruto dessa identidade cultural carioca que consegue transcender a fome com a alegria. Vendia picolé na praia e na feira, engraxava sapato quando não fazia sol, subia e descia até a bica do morro para pegar água e jogava futebol 
com bola de meia em frente ao campo do Botafogo. Como uma criança do morro, da favela, tive três caminhos apontados claramente em minha vida: ou seria um bandido, como muitos de meus amigos, um tio e um irmão que vi morrer, ou seria um jogador de futebol, pois nasci com o dom e o talento com a bola, ou seria um artista, um ator, já que desde sempre eu via o mundo como imagem, ação, poesia e sentimento.

O palco e a bola eram os meus refúgios necessários, sem os quais eu não poderia viver, mas com uma arma certamente iria morrer mais cedo e eu queria dizer sim à vida, e porque precisava encontrar saídas para a fome e a bandidagem e aprimorar os meus talentos artísticos, aos 16 anos entrei numa escola de Arte. Depois de vários testes práticos, ganhei uma bolsa integral na Escola de Artes Visuais (EAV), no Parque Lage, Rio, onde aprofundei o conhecimento das Artes Cênicas, especialmente em Cenografia, construção de bonecos e adereços, e estudei Desenho, Pintura, Projeto Gráfico, Gravura em Metal, Litografia, Serigrafia, Xilogravura, Escultura, Cerâmica (Artes do Fogo), como matérias práticas, e, como complementação teórica, História da Arte, História do Cinema e da Fotografia. Isso era nos anos 70 e o Parque Lage era um foco de resistência cultural à ditadura. Mesmo diante da crise institucional e política, era o tempo da diversidade cultural e no Rio chacoalhavam os happenings, os parangolés de Hélio Oiticica (seja marginal, seja herói), os cenários de Hélio Eichbauer, a dança de Klaus Vianna, a poesia marginal, o teatro de resistência política e o cacete da polícia política comendo nos atores e atrizes, que nem tinham reconhecimento como profissionais.

Já no Parque Lage, comecei a viver do que fazia, conseguia me sustentar como artista, com a venda de desenhos e gravuras, e a apresentação de espetáculos com cenas curtas que fazia pelas ruas da cidade, quando passava o chapéu e dava para ganhar alguns trocados. Também participei de exposições coletivas de artistas a favor da anistia ampla, geral e irrestrita, na ABI (Associação 
Brasileira de Imprensa), no MAM e na Cinelândia, palco de movimentos populares no centro do Rio.

$\mathrm{Na}$ Escolinha de Arte do Brasil, do mestre Augusto Rodrigues, tive o meu primeiro contato com a Arte-Educação e comecei a trabalhar com crianças. Paralelamente aos meus estudos nos Parque Lage e na Escolinha de Arte, me formei em Desenho de Arquitetura como uma maneira de conseguir trabalho como desenhista técnico nas empresas, mas optei em ensinar às crianças o que sabia em Arte e não contribuir produtivamente para o milagre econômico brasileiro, como um simples funcionário, mão de obra barata de uma multinacional qualquer, pois eu tinha muito que dizer e contestar.

Já em São Paulo, me formei em Filosofia e atualmente desenvolvo, como mestrando, o projeto de pesquisa "A estética do teatro desagradável e a subversão do belo na obra teatral de Nelson Rodrigues", na Universidade São Judas Tadeu, como bolsista da CAPES. Participo ativamente na vida cultural da cidade como ator, diretor, autor, cenógrafo, carnavalesco, professor, orientador de Artes Cênicas de grupos de teatro amador, no Projeto Ademar Guerra (Secretaria de Estado da Cultura), realizo atividades com professores em programas de qualificação (SIMPRO/SP, FAFE/USP, PUC/SP) e faço seminários de Teatro e Filosofia da Arte em universidades e entidades culturais, públicas e privadas.

\section{Qual foi sua relação com o Ventoforte? Como entrou para o trabalho do grupo, tempo de permanência, de que atividades participou e de quais espetáculos?}

Conheci o Ventoforte no Teatro Cacilda Becker, no Largo do Machado, Rio, não sei se em 1976, quando assisti Pequenas histórias de Garcia Lorca. O Rio fervilhava com o Asdrúbal Trouxe o Trombone, os shows de Milton 
Nascimento, Hermeto e Fagner no MAM, o Teatro Opinião, o Teatro Teresa Rachel, o píer de Ipanema e os sovacos eruditos (expressão que inventei para caracterizar os intelectuais da resistência, sempre andando com os seus livros de Sartre, Heidegger, Adorno, Benjamim, Marx ou Nietzsche debaixo do braço) na porta do Cine Paissandu delirando com Godard, Glauber Rocha, o realismo italiano, enquanto na Cinelândia e na Praça Tiradentes imperava o Teatro de Revista e Nelson Rodrigues metia o pau na esquerda e nos padres de passeata que protestavam por Cuba e não pelo Brasil. Mesmo com a minha "vivência" em Teatro desde criança, foi ao ver Bibi Ferreira em Gota d'Água, de Chico Buarque, no Teatro Carlos Gomes, na Praça Tiradentes, que resolvi ser ator. Dito e confirmado isso para mim mesmo, um jovem artista inquieto procurando caminhos, passei a assistir quase todos os espetáculos da cidade e foi assim que eu conheci o trabalho do Ventoforte.

Quando vi Pequenas histórias de Garcia Lorca, as cadeiras que se arrastavam e o elenco cantando limpo e afinado transmitiam uma cumplicidade cênica impressionante, como uma tribo que canta e dança num ritual de vida e de morte. Sempre digo ao Ilo que, para Pequenas histórias de Garcia Lorca ser considerado um espetáculo teatral perfeito e mágico em toda plenitude, só faltava que o público sentisse o cheiro de alho, vinho e cebola. Era um espetáculo rico e forte em sua movimentação cênica, havia sinceridade nos atores e era tudo tão vibrante, como anjos escorrendo pelas catedrais, mas faltava o cheiro andaluz de Lorca. Foi só com Choro Lorca, já em São Paulo, que essa falta poética pôde ser preenchida. Fiquei atento ao trabalho do Vento, fui aos camarins, conversei com o llo, a Sílvia Aderne e o Paulo César Brito e, encantado, mas ainda não fascinado como quando fiquei ao ver Bibi Ferreira atuando, quis ver o próximo espetáculo do grupo.

Ganhei uma bolsa de estudos para participar do Festival de Inverno de Ouro Preto em 1979 e, por uma daquelas coincidências da vida, viajei no 
mesmo ônibus do grupo, que estava indo ao festival para apresentar Mistério das Nove Luas no Teatro Municipal. Foi aí que eu, de fato, consolidei a minha admiração pelo trabalho do grupo. Eles fizeram uma apresentação encantadora e aqueles bonecos enormes, as músicas e as danças fascinaram o público, que aplaudiu de pé. Quanto a mim, fascinado pela linguagem, as cores e os sons do espetáculo, guardei na lembrança a imagem de uma mulher parindo centenas de filhos e uma canção que falava de uma certa Dalva que estava louca para amar. Tempo e transcendência se misturavam num espetáculo vigoroso e poético; foi amor à segunda vista e paixão à primeira música. Depois de atuar no filme de Walter Lima Júnior, Chico Rei, em Ouro Preto, mudei para São Paulo.

Cheguei em São Paulo no final de 80, início de 1981, com um book cheio de fotos para deixar nas agências de atores, um portifólio com desenhos, pinturas e gravuras para vender nas galerias de Arte e uma pasta com vários textos teatrais de minha autoria, à procura de grupos para encená-los. Fui almoçar com o llo, a comida da Cilene (a famosa Pudim, cozinheira do Vento durante muito tempo) com a Diana cheirando meus pés (cadela mascote da casa da Tabapuã) e o Daniel (filho da Cilene) choramingando ao lado do fogão. $\mathrm{Na}$ casa, comecei a trabalhar com as crianças e o llo, vendo as minhas múltiplas facetas artísticas e querendo me integrar ao elenco do Vento, propôs que eu entrasse no curso de formação de atores, já que sairia dali um espetáculo e ele estava formando um novo elenco, pois na mudança do Rio para São Paulo o elenco carioca que começou com Lenços e ventos e $O$ barquinho se dispersou e alguns não vieram para São Paulo. Resumindo: o primeiro Curso era a forma que o llo encontrava não só para passar os seus ensinamentos, mas também para formar o seu elenco paulistano.

Foi daí que surgiu o primeiro núcleo paulistano do Vento, com Pedrão do Maranhão, eu, Tião Carvalho, Marilda Alface, Thaya Perez, Graziela Rodrigues, Beto Andretta, Paco, Ana Van Steen, Rosa Comporte, Rita Coelho, 
Edilson Castanheira, Márcia Cabral, Edgar Lippo, Selma Bustamente, Laurent Lucien, Jorge Bóris, Fernando Gatti, Isa Uehara, Marta e Ná Ozetti, Osvaldo Gabrielli, Peninha, Paulo da Rosa, o saudoso Jorge Odara e muitos outros, responsáveis por vários espetáculos.

O meu primeiro trabalho oficial com o Vento foi a gravação de um disco infantil, O gigante azul, um fragmento de Da Metade do Caminho ao País do Último Círculo, um texto pouco montado do llo, da Coleção Taba, editada pela Abril Cultural, gravado nos estúdios da Rádio Transamérica, em que fiz algumas vozes e personagens. $O$ convite para a gravação surgiu graças a uma aula sobre contos de fadas e contadores de histórias e o llo gostou muito da minha contação d'O Rouxinol, e a partir daí muitas coisas boas viriam.

Nessa época, llo juntou um grande elenco para montar Histórias de Fuga, Paixão e Fogo, um título belíssimo para um caos cênico e estético que misturava o Século das Luzes, do cubano Alejo Carpentier, com batuques para Oxum, lutas e guerreiros, procissões, ladainhas e igrejas incendiadas, que tinha três horas e pouco de duração e chegou a ser apresentado no Sesc Pompéia algumas poucas vezes, para um público reduzidíssimo. Dessa verdadeira loucura, dessa empreitada épica, participei timidamente na confecção de algumas máscaras e adereços, ajudando Edilson Castanheira e Osvaldo Gabrielli na construção infindável dos objetos; o espetáculo se apresentava com cola e tinta ainda fresca, das coisas que não acabavam nunca.

Participei ativamente do Ventoforte de 1981 a 1996, desde a casa da Tabapuã até a construção e implantação do novo espaço no Parque do Povo. Muito próximo ao llo como amigo e como um artista cúmplice de suas propostas e ele das minhas, apresentei a ideia, que no início parecia um sonho ou um desejo inatingível, da ocupação de um espaço, já que a casa fora pedida pelo proprietário e isso seria, fatalmente, a desmobilização do grupo e de todo o nosso trabalho. Conseguimos o terreno, levantamos a cerca, plantamos milho, fizemos uma 
fogueira e eu fotografei e participei de todo o processo da obra e também pintei as placas indicativas do novo espaço, que vi transmutar-se de um sonho distante para uma realidade palpável.

Trabalhei como ator, cenógrafo, construí bonecos, marotes e máscaras para vários espetáculos do grupo e, como professor do Curso de Formação de Atores e do de Artes Integradas para crianças, ajudei a formar as gerações seguintes do Vento. Ilo me instigava a usar todas as minhas potencialidades artísticas e trabalhamos em dupla, como criadores, em várias peças do grupo. Tive o prazer de compartilhar das suas idéias e de apresentar as minhas para a criação dos espetáculos. Trabalhávamos em sintonia e produzíamos muito: llo apresentava uma ideia e eu a colocava em prática, principalmente na parte cenográfica e de construção de bonecos e adereços. Ilo Krugli foi o único artista que eu consegui fazer junto uma obra e, inclusive, pintamos a quatro mãos um painel enorme com os dizeres de Garcia Lorca, do Romanceiro Gitano, "a Lua é um tamborete de cetim branco para os ricos e um pão para os pobres", para uma exposição no Centro Cultural São Paulo, chamada Arte contra a Fome.

O meu primeiro trabalho teatral propriamente dito com o grupo foi uma substituição em Os Misteriosos Pássaros de Barro, e depois fiz Brinquedos da Noite, espetáculo-depoimento baseado nas experiências dos atores, premiadíssimo pela crítica, com direção de Paulo César Brito. O Vento, nessa época, se desdobrava em dois elencos, e assim, era um grupo de repertório, com várias peças em cartaz e sempre com a casa cheia. Nos finais de semana nos apresentávamos e durante a semana fazíamos aulas com o llo e ensaiávamos os novos trabalhos. Fazíamos uma peça atrás da outra e logo veio Caminhadas, com Tião Carvalho e Graziela Rodrigues, um belíssimo espetáculo de teatro e dança, em que fiz os cenários, junto com Pedrão do Maranhão. Depois entrei de verdade como ator em As quatro chaves, um roteiro aberto, um exercício transformado em 
espetáculo de rua, com a efetiva participação lúdica do público, em que atuei como o narrador e o detetive e pintei os painéis cenográficos.

No Labirinto de Januário, fui o Januário, menino pobre que sonhava com o cavalo alado, engraxate como eu fui de verdade, e também construí todos os bonecos e adereços, junto com Edilson Castanheira. Ensaiamos um ano e meio, durante as obras do novo espaço, e participamos de vários festivais, inclusive com muitos prêmios. O Labirinto, com duas horas de duração, foi um dos espetáculos mais premiados do Vento e, curiosamente, um dos menos vistos pelo público. Devo dizer que o processo de montagem foi conturbado, com substituições de atores e a mudança para o novo espaço (tomávamos choques com nossas lanças e espadas nas ferragens da obra), além das viagens com os outros espetáculos já prontos.

Vai aí um resumo das minhas participações no Vento, entre as atuações, os personagens e a construção de bonecos, cenários e adereços: As Quatro Chaves (narrador e detetive), Lenços e ventos (vários), Barquinho (vários), Choro Lorca (vários), O labirinto de Januário (Januário), A tempestade (Caliban), foram os espetáculos em que atuei e também fiz os cenários, os bonecos, os adereços e os objetos cênicos. Em Brinquedo da noite e $A$ tempestade apenas atuei, e em Caminhadas fiz toda a cenografia, junto com Pedrão do Maranhão. Em Sete Corações concebi e construí os bonecos e objetos com José Gallas, e em Dois Irmãos, espetáculo com os nossos alunos, resultado do Curso de Formação de Atores, coordenei, como professor de Cenografia, máscaras, marotes e bonecos de luva e vara, todo o trabalho de investigação estética do conto dos irmãos Grimm.

Também vale a pena registrar o trabalho que fazíamos com as crianças da Favela JK, perto da Funchal. Levávamos papéis e instrumentos musicais e ensinávamos a construir bonecos, cantar cirandas e cantigas; era um 
pouco de sonho e poesia, alimentos para a alma, para quem vivia no esgoto e tinha fome de tudo. Havia uma menina, a Íris, de 10 anos, que recolhia jornal velho e papelão com sua carroça, para sustentar a mãe doente e o irmão menor. Quando ela descobriu que poderia, além de sobreviver, também brincar com bonecos de jornal e construir cenários de papelão, ela trouxe de volta a criança linda e alegre que vivia escondida nela pelas agruras e exigências de uma vida adulta. Conquistas como essas eu poderia contar muitas e vale só mais uma para ilustrar o alcance sócio-cultural do nosso trabalho: ensinei as crianças da favela a fazer cavalos de pau com caixas de sapato e eles passaram a vender na feira livre e nas festas do Vento os seus cavalos. Também teve o projeto de arte-educação, Interação Escola e Comunidade, em parceria com a Fundação Pró-Memória, que fizemos na E. E. "Aristides de Castro", no Itaim, com ótimos resultados artísticos e pedagógicos. Com o Ventoforte, a Favela JK e a escola do bairro nunca mais seriam as mesmas. Tínhamos uma atuação muito positiva no bairro do Itaim Bibi, pois se é uma característica do bairro estabelecer uma fronteira explícita entre o poder e a miséria, nós integrávamos as classes, já que o nosso público era composto pelos filhos da classe média alta que conviviam perfeita e poeticamente com os meninos descalços da favela, ao assistir e participar de um espetáculo como As Quatro Chaves, por exemplo, ou de brincar de roda num evento de rua ou nas nossas aulas abertas no quintal de casa. Aos sábados e domingos, na Rua Tabapuã, nos idos de 81 a 84, o Teatro Ventoforte fincava o seu mastro, hasteava a bandeira da poesia e um menino descalço, barrigudo, faminto e desdentado dava as mãos a uma menina dourada pelo sol, ao som de "passa, passa, gavião, todo mundo passa..." e todo mundo passava, sorrindo o mais puro dos sorrisos.

Das experiências com as crianças da favela, do bairro e da escola, partimos para outros projetos, como os mutirões da Zona Leste da cidade, em parceria com a prefeita Luiza Erundina. Como uma forma de integrar o Teatro, a Arte, como instrumento de ação cultural objetiva, a uma ação política e popular, nós trabalhávamos com os mutirantes e os seus filhos. Esse trabalho teve um alcance tão grande que até hoje, nos mutirões da Zona Leste, ainda existe a 
lembrança de um grupo de atores e artistas cirandeiros que ensinou muita coisa para eles. Ainda há desdobramentos sociais e culturais dessa época, especialmente, nos mutirões São Francisco, Associação XV de Novembro de 1988 e na Fazenda da Juta, onde as crianças de outrora, hoje são mães e pais que cantam cocos, cirandas, pastoris e contam histórias para os seus filhos. Quando atualmente sou reconhecido por eles ao fazer um trabalho na região, afirmo para mim mesmo que valeu muito a pena comer tanta poeira e agüentar duas horas na Paloma (nossa primeira Kombi) até os mutirões para cantar, brincar e encantar aquele povo todo, que dava um duro danado para realizar o sonho de construir e ter as suas próprias casas.

Formei dupla de trabalho com o llo durante muito tempo, quando ele era convidado para dar oficinas em universidades e escolas em outros estados e até em outros países, como na Nicarágua, quando fui com ele e Beto Melo, convidados pelo governo sandinista recém-empossado, de Havana/Cuba para Manágua, trabalhar com jovens nicaragüenses numa casa chamada Casa de los Trabajadores de la Cultura, criada pelo poeta brasileiro Thiago de Mello e outros artistas latinoamericanos. Pagamos, cada um, \$25,00 para entrar no país, como uma taxa de estado de guerra. A capital nicaragüense tinha toque de recolher, se ouviam estrondos ao longe, toda hora passava um caminhão do exército sandinista levando os contra-revolucionários (soldados mercenários financiados pelos EUA) presos, os carros caíam aos pedaços, a cidade estava destruída e faminta, Anastásio Somoza havia caído, os sandinistas assumiram o poder e, no centro da cidade, numa praça rodeada por igrejas e prédios em ruínas, onde havia a estátua de Somoza, eles ergueram a de um guerrilheiro brandindo sua metralhadora para o céu, num grito de liberdade. Nós fomos lá para implantar uma proposta de arte-educação num país que estava destruído pela guerra e pelos terremotos e precisava ser reconstruído. Fomos agentes históricos multiplicadores, mas só depois de algum tempo é que fomos perceber a dimensão histórica, política e cultural do nosso papel ali naquele momento, da nossa ação cultural. Ainda na Nicarágua, eu peguei uma febre tropical e não conseguia comer 
nada e, com o país em guerra, a comida era escassa e o llo e o Beto, cheios de fome, comiam o meu punhado de macarrão, arroz e ervilha, enquanto eu só conseguia ingerir líquidos.

Houve uma experiência muito importante também no Peru quando, com o llo e a Fátima Campidelli, fomos apresentar As Quatro Chaves (espetáculo originalmente feito por 10 atores) para uma população indígena que vivia nas favelas de Lima, e dar aulas de teatro para os professores da capital peruana, na programação do Festival Internacional de Teatro para la Infancia y la Juventud, com a participação de grupos de teatro de várias partes do mundo. $O$ aspecto importante dessas viagens com o llo é que levávamos as nossas experiências artísticas e pedagógicas para países ávidos e necessitados de novas práticas para a educação de suas crianças e jovens.

\section{Como foi sua aprendizagem em Arte no Ventoforte?}

Com as crianças, no curso de Artes Integradas, eu ensinava sambas-de-roda do Morro do Pasmado, no Rio, cantigas, brincadeiras, danças de roda e fazia oficinas de construção de bonecos com jornais, papéis de seda e papelão. Iniciei uma pesquisa rigorosa de folguedos e recolhi pastoris, cocos, reisados, jongos e batuques (da minha infância). Era uma forma de pegar a criança primeiro pelo corpo, pelo jogo, pelo ritmo pessoal e comum, para depois trabalhar com as cores, as mãos e construir bonecos e formas animadas.

Foi no primeiro curso de formação de atores do Vento que, como aluno do Ilo, pude aprimorar as minhas potencialidades enquanto ator e enquanto artista plástico. Depois fui convidado para ser um dos professores do curso, responsável pela pesquisa estética (cenografia, maquetes, bonecos e objetos), fazendo parte do núcleo de professores do Vento, junto com llo, Paulo César Brito, Thaia Perez, Graziela Rodrigues e Tião Carvalho. 


\section{De que maneira a proposta estética e pedagógica do llo afetam o seu trabalho? (Artístico/Pedagógico com crianças e adultos)}

Por ter trabalhado junto com llo em várias peças, como ator, como cenógrafo e, principalmente, por ser seu amigo, naturalmente as suas propostas pedagógicas e estéticas afetaram o meu trabalho. Afetaram tanto que fui considerado por alguns atores, do Vento e de fora do Vento, do meio teatral paulistano e carioca, como um herdeiro do llo. Mas tenho o meu caminho e, por um princípio aprendido com Sêneca, filósofo latino, prezo as minhas amizades na medida em que posso criticar e ser criticado pelos meus amigos, porque acredito que o amor, a amizade verdadeira (a phylia grega), permite que um amigo aponte as coisas para um outro amigo ou que um discípulo queira ir um pouco mais longe que o seu mestre. Logo que saí do Vento, não sei se em 1996, depois de $A$ Tempestade, carregava comigo as suas influências, mas atualmente estou desenvolvendo as minhas próprias estratégias de trabalho com o Teatro, a ponto de já ser identificado por meus alunos, atores que dirijo e pelo público que assiste aos meus espetáculos, com um estilo característico do Laranjeiras, que estou suando muito para conseguir, com muito estudo e pesquisa. Eu já era um artista quando conheci o llo e o Ventoforte no Rio e procurava, com a inquietude juvenil que move todo artista, um caminho para o meu trabalho, e o nosso encontro foi o encontro de dois artistas que se encontraram num determinado ponto de suas vidas.

Acho que muitos de nós, com suas várias influências artísticas, do Maranhão, do Rio, de Pernambuco e de São Paulo, também influenciamos a estética e a pedagogia do llo, que sempre se mostrou muito hábil em mexer o

caldeirão cultural que era o Vento e em fazer, como só um mestre sabe fazer, a convergência das nossas várias referências artísticas e das nossas diversificadas identidades culturais. Nos ensaios e sensibilizações que fazíamos para os 
espetáculos, levávamos os nossos repertórios e apresentávamos ao llo, que, se percebesse ser útil ao espetáculo, encampava as nossas idéias, mas se não fosse, ele soltava a sua famosa e antológica frase: "esto no me serve", e partíamos para outras propostas até a plena satisfação do mestre. Dava gosto ver o brilho dos seus olhos azuis quando fazíamos algo que ele gostava e aprovava cênica, estética ou até dramaturgicamente (muitas e muitas vezes mudávamos os seus textos). Como diretor, ele sabia muito bem assimilar as propostas e idéias dos atores, desde uma simples caracterização de personagem até as músicas que recolhíamos de nossas memórias musicais e culturais. A estética do Vento, a sua musicalidade, tinha muito dos artistas do grupo e o llo era o nosso timoneiro, o condutor dos nossos talentos, e tanto nós quanto ele aprendíamos e ampliávamos assim os nossos horizontes artísticos.

\section{Descreva com riqueza de detalhes as etapas de uma proposta de aulas/exercícios do llo.}

A resposta a esta pergunta depende de que proposta do llo se fala, porque se for um trabalho de sensibilização com as quatro idades, se dá de uma forma, e se for, por exemplo, com o mapa da vida ou os quatro elementos, ocorrem estratégias distintas. Esta é uma resposta que eu precisaria de mais tempo para responder satisfatoriamente, assim como a pergunta acima.

\section{Existe algum aprendizado, algo de importante que você "carregou" do Ventoforte e do llo com você, na sua prática artística, na sua visão de mundo?}

Naturalmente que existem, pois foram praticamente 15 anos de trabalho com o llo e o Vento em muitos espetáculos. Além dos trabalhos como ator, bonequeiro, cenógrafo, aderecista e arte-educador, também convivi e participei com o llo de experiências políticas e culturais como as realizadas na Nicarágua e no Peru, descritas acima. O mais importante é que o Teatro que faço atualmente é feito para o homem de olhos abertos, e essa é uma característica, um traço 
fundamental do trabalho do llo que sempre carrego comigo. Usando uma expressão do próprio llo, eu poderia dizer que a imagem que traduz o que sinto pelo Vento é a seguinte: o Ventoforte foi uma paisagem colorida pintada no mapa do meu corpo, uma linha em que eu amarrei a minha pipa e pude deixá-la voar livremente.

Luiz Carlos Laranjeiras, ator, autor, diretor, arte-educador, artista plástico, carnavalesco, professor, orientador de Artes Cênicas e filósofo (um ator doado à Filosofia), carioca, com 46 anos de existência e de resistência, sempre acreditando que a vida sem a Arte seria um erro e que onde há poder deve haver, ao menos, a possibilidade de uma resistência e eu estou aqui no mundo, nasci, não para fazer uma simples reação, mas para buscar com o corpo e a alma as ferramentas artísticas e filosóficas para uma resistência criativa.

\section{O Ventoforte faz um teatro de essência ritualística}

Paulo César Corrêa de Brito, ator, educador, terapeuta corporal. Nasceu no Rio de Janeiro e entrou no grupo Ventoforte para fazer uma substituição em 1975.

No tempo de permanência, até 1986, desenvolveu espetáculos como ator e diretor. Dirigiu grupos de alunos e foi professor nos cursos mantidos pela Casa do Ventoforte. Em entrevista pelo telefone, ele reflete sobre a prática do grupo.

Paulo César é sobrinho de Sérgio Brito e, apesar da tradição artística na família, afirma que sua iniciação teatral aconteceu com o Ventoforte porque fortaleceu um lado popular, trouxe o lado negro das religiões afro-brasileiras, pelo qual ele já se interessava. 
O que o encantou foi o trabalho com objetos simbólicos, o inconsciente individual e coletivo.

"Em As pequenas histórias de Lorca, em 1976, éramos eu, Regina Costa, Eduardo Machado, Sonia Piccinin, Sílvia Aderne, Beto Coimbra, Neusa Navarro, Biza Viana, Xuxa Lopes, Sérgio Fidalgo e o llo Krugli. A direção musical foi do David Tygel.

Fizemos um Lorca nordestino, D. Cristóvão e Sinhá Rosita que começava com Assum preto... "Talvez por ignorância, ou mardade das pior, furaro o zóio do assum preto pra ele assim cantá mio". Uma analogia ao próprio Lorca.

E o Antunes não saía do Lorca, naquela época era diferente, os críticos viam os ensaios, conversavam com a gente e falaram do encontro do poeta Lorca com o poeta llo."

"O llo tem o dom de mexer com a emoção das pessoas, ele fazia naquele momento um teatro despojado, um brinquedo vivo, a arte popular, o auto popular, fazia a transposição do auto popular para a cena. Não era uma cópia do auto, trazia algo mais em linguagem cênica.

Quando fizemos Histórias de lenços e ventos nos presídios, em 1976, no projeto Pacote Cultural, do Paulo Afonso Grizzolli, fizemos várias cidades e os presídios, Bangu, Niterói, os presos choravam, choravam e nos pediam os lenços.

É que tinha uma religiosidade meio mística, meio invisível que se materializava naquele produto.

Em Artigas, no Uruguai, quando estreamos Sonhos de um coração brejeiro naufragado de ilusão, ensaiávamos, finalizávamos os objetos. Quando estávamos indo embora, uma moça disse que não sabia que religião era aquela que nós tínhamos e pediu para que rezássemos por ela. Nós fazíamos tudo, bonecos, figurinos, cenários e ensaiávamos e a comunidade assistia.

O mundo mudou, não há coesão de grupo, disposição dos atores em busca de uma linguagem. Não há tempo de se dedicar só ao teatro. 
Nós tínhamos uma pureza, no bom sentido, naquele tempo, tínhamos disponibilidade. O llo continua o mesmo, mas a criação se perdeu, o trabalho de ator se era sensibilizar a pessoa e trazer para aquele contexto teatral, para que 0 ator pudesse acontecer, celebrar. Falta o ritual puro.

Há um barroquismo na linguagem, falta síntese, dentro de um espetáculo tem 10. A coesão interna e a celebração se perderam.

O grupo sempre viveu muitas crises: perda de pessoas, centralização de poder e espaço... Mas hoje as pessoas saem do trabalho com muita facilidade, antes era quase uma separação. E por que elas saem? Sobrevivência? Um outro tempo? Despertávamos o novo, éramos o novo, já não é tão novo, não traz tanto público?

O Ventoforte é o llo, é uma linguagem, um espaço que acredita na individualidade das pessoas. Não é cultuado hoje, mas a semente está lá."

\section{Da França à continuidade ética e poética.}

"Sou formado pela USP em Licenciatura em Artes Cênicas, mas minha formação realmente se desenvolveu e se desenvolve no trabalho de um 'teatro de grupo', no qual acredito e me dedico, como também nos ateliers e oficinas dirigidos a um público variado que nunca parei de conduzir ao longo dos anos em

que faço teatro. Aliás eu sempre me defini muito mais como alguém que faz teatro do que ator, diretor ou professor.

O trabalho simbólico e a linguagem teatral que o llo propõe eu os encontrei pela primeira vez quando ainda fazia parte do Grutemon, um grupo de teatro amador, da Vila Morais, zona sul de São Paulo. E do qual faziam parte muitos dos que acabaram integrando o Vento mais tarde: Paulinho da Rosa, Jorge Bóris, Selma Bustamante, Benê.

Na época estávamos trabalhando uma peça dirigida por alguém (Evaristo, não sei o sobrenome) que acabava de fazer um curso com o llo e naturalmente, 
como sempre acontece, tinha sido extremamente influenciado pelo universo poético proposto pelo Ilo. Eu fiquei sabendo do Vento antes de ter visto seus espetáculos e antes que ele se transferisse para São Paulo.

Depois disso acabei finalmente vendo o Pequenas histórias de Garcia Lorca no Teatro Arena, atualmente Eugênio Kusnet, e ali foi como um furacão, com o espetáculo culminando na rua, às portas do teatro. Sempre gostei da rua, e sempre me incomodou um teatro confinado simplesmente ao palco das casas de espetáculo.

Depois vi o Sonhos de um coração brejeiro naufragado de ilusão no Teatro Artur Azevedo, o Mistério das nove luas num projeto do Sesc no Dr. Vila Nova, e finalmente o Vento tinha idéia de se transferir para São Paulo e o llo desenvolveu um curso numa garagem residencial de uma rua paralela à Av. Brasil, onde foi a primeira vez que tive um contato com ele e sua proposta mais diretamente.

O que me atraiu, de cara, foi a profundidade do trabalho calcado no imaginário de cada um. Em que os exercícios propostos eram sensíveis e abriam portas e portas no interior de cada um. No curso ficou evidente também que, muito embora o llo fosse o timoneiro, o Vento era o trabalho de um bando coeso, solidário, onde cada um tinha seu lugar e ia fundo em suas potencialidades.

Quando do meu ingresso no grupo confirmei o que intuía, ou seja, que o Vento é como um jardim propício a toda sorte de flores e... espinhos, e o llo o jardineiro que as auxilia e permite crescer e que, fundamentalmente, como todo mestre são os mestres que o fazem -, sabe lidar com o tempo, cronológico e atmosférico.

Enfim, o Vento ampliou em mim as dimensões do palco em todos os sentidos, e o elevou ao campo do sagrado. As montagens do Vento são como manipulações alquímicas, feitas com amor, carinho, de maneira artesanal.

Eu integrei o Vento entre 1983 e 1990. No início participei como aluno em um projeto de contos de fadas que culminou no espetáculo Os cisnes selvagens, 
apresentado em parques, praças, favelas, feiras, e que acabou entrando em cartaz no próprio teatro do Vento, ainda na Tabapuã.

Logo depois ingressei no elenco do Brinquedo da Noite, de Paulo César Brito e quase na mesma época fui convidado pelo llo para participar do Labirinto de Januário. A criação foi longa e durou um ano e meio, e coincidiu com a construção do espaço onde o Vento se encontra hoje. Lembro que chagamos a ensaiar o Labirinto em pleno inverno, em chão de terra batida no galpão ainda em construção, onde hoje se encontra a lareira.

Depois fizemos Sete Corações, Choro Lorca, uma remontagem de a História de Lenços e Ventos que se apresentou em Cuba, e integrei em substituição na História do Barquinho e As Quatro Chaves.

Isso sem contar as inúmeras festas de aniversário, que no começo eram feitas no antigo Vento, em plena Rua Tabapuã bloqueada ao trânsito. A festa durava o dia todo, até a noite, com trechos de peça, canções, boi, caroço, oficinas. As festas continuaram no Vento novo, ligadas aos temas como os quatro elementos; ou ao galo (festa do galo: galo da manhã, galo do meio-dia, galo da meia-noite, galo da madrugada); e outras, sempre com temas estimulantes e organizadas com paixão, alegria, partilhadas com amor junto ao público amigo.

Em termos de arte-educação participei de alguns projetos como o circo piloto da Secretaria Estadual do Menor na Freguesia do Ó; um trabalho com crianças de cortiços, em praça pública e na rua, no Brás e Glicério, com a mesma secretaria; e durante algum tempo conduzi um dos cursos de adolescentes no Vento, cursos que eram coordenados por Selma Bustamante.

No Vento não há meias medidas, eu ingressei no grupo e me dediquei de corpo e alma.. Aprendi muito, muito, muito... Me doei muito, muito, muito e fui extremamente marcado por tudo que ali vivi. Carrego o Vento em mim à minha maneira, digerido à minha maneira, pois o llo e o Vento propõem não um modelo, mas uma direção, uma procura.

Trabalhei no Piauí durante 6 anos, com atores de lá, alguns que iniciei; com meninos de rua; com filhos de quebradeiras de coco babaçu; educadores 
populares, etc... E Vento esteve todo tempo presente em mim como uma parte preciosa de meu caminho.

Agora na França, há 7 anos, tendo trabalhado com desempregados, deficientes físicos e mentais, ciganos, imigrantes, populações de bairros desfavorecidos, o Vento continua presente em mim, não como uma memória estética, passada, mas como uma referência ética, poética e de busca constante.

O teatro que o Vento propõe, que o llo propõe, e que integra a música, as artes plásticas, a poesia, e o espaço de encontro onde a história e a cultura de cada indivíduo podem se manifestar, não como uma cópia do real, mas em transcendência e transformação.

O mapa da vida é isso: o presente, paisagem de um caminho e seus segredos, medos; o futuro, um desconhecido, alimentado por desejos, vontades, buscas; e o passado, um lago-memória nebuloso onde vamos resgatar imagens e sensações resvalando o espaço mítico.

Sou Laurent Mattalia, tenho 48 anos, homem de teatro..." 


\section{Em MAIO, sempre é o aniversário do VENTOFORTE... desde Maio de 74.}

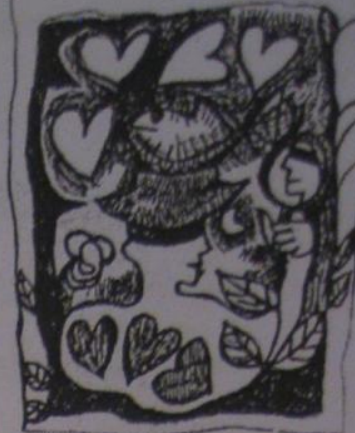

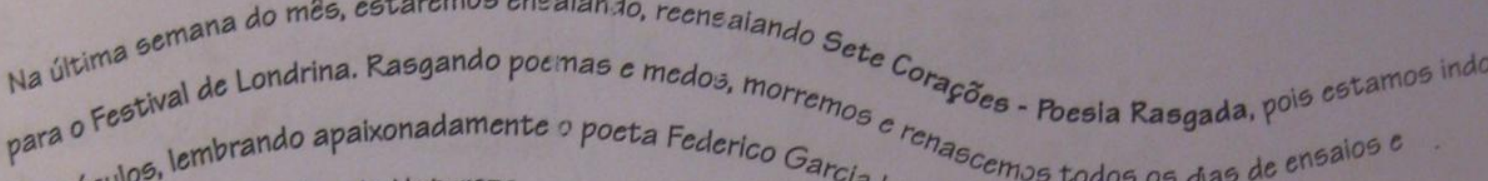
espetáculos, lembrando apalyo caminhar da Natureza.

eno tatro, e no caminhar da Natureza. "Ca. Sos nossos "papéis" na vida

No domingo 25, interromperevios als 19 horas o ensaio para lembrar os 23 anos do VENTO.

Nesse dia, à noitinha, eu me convido a levar um papo noVENTO (oVENTOFORTE geralmente não me convida, me obriga) - portanto eu me convido e convido vocês a um papo não muito longo, nem muito racional, talvez irracional? talvez sobrenatural? talvez apenas fantasiosamente incomum... mas sinceramente, esboçando novos caminhos, e novos caminhos velhos, que nos levaråo, a partir de 1998, ao movimento e aos passos da nossa "chegança" no próximo milênio - $2.000 \ldots$

É preciso chegar de coração e olhar abertos, trazer as comidas
Deuses do Teatro, e à Natureza, mas também para algradas, doces ou salgadas, para oferecer a0s Teatro - atores e músicus, poet alimentar, agradar, vitalizar os escravos dedicados do

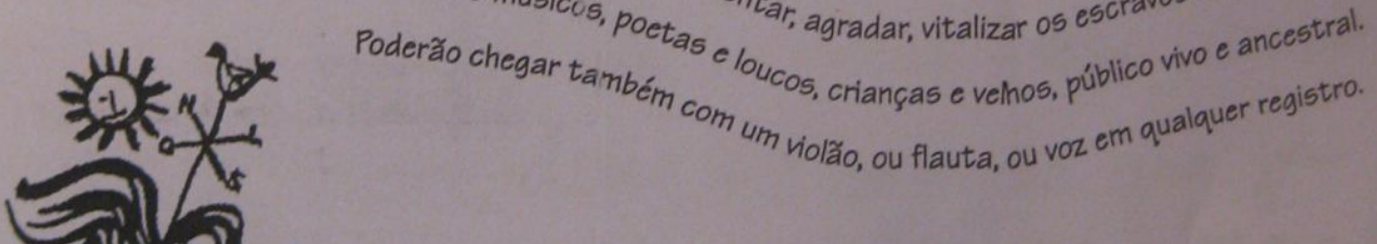
을

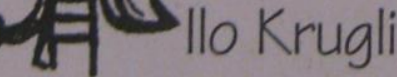

Durante os festejos serão sorteados painéis dos que

RUA BRIGADEIRO HAROLDO VELOSO 150 - ITAIM BIBI FONE: 820.3095 FAX: 866.9626 realizamos em cada espetáculo, aqui no Vento generoso de Maio.

Convite. Comemoração Aniversário Ventoforte. Arquivo Andrea Cavinato 
am anbia no balle no castelo do principe, - todos elogiaram a rosa vermella no men peito. e dancarei com ele e tod os rapazes bonitos da festa... dise a fovem .... de cabelos emufrid. Eu sou una rosa inexistente,..... em o men vermedho, minhas petalas sāo inex. tentes, 0 annor e a alesria sās inexictentes. in ... rexistente ... existente..

Existo ou nas exvato?

disse a ros a inexptes

* Esta historia, é a historia denua rosa vermellna .... kelo anor en saco tudo.. ate... una rosa vermelina disse o Rouxinho que ja cantavo a mais de misl anoo..

Manuscrito do texto Histórias que o eco canta, de llo Krugli. Arquivo: Andrea Cavinato

262 


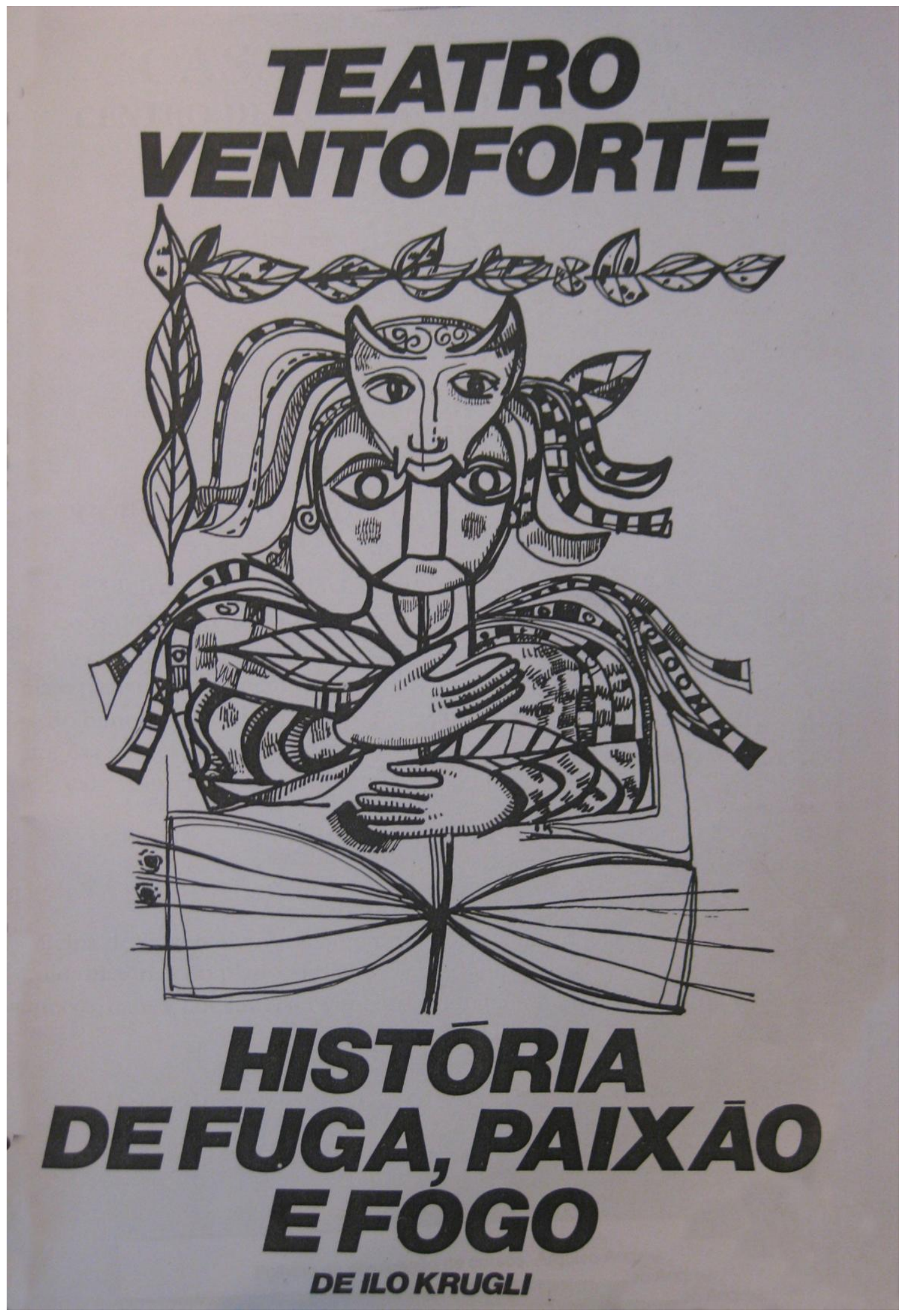




\section{CASA VENTOFORTIE CENTRO DE ARTE E CULTURA INTIEGRADA}

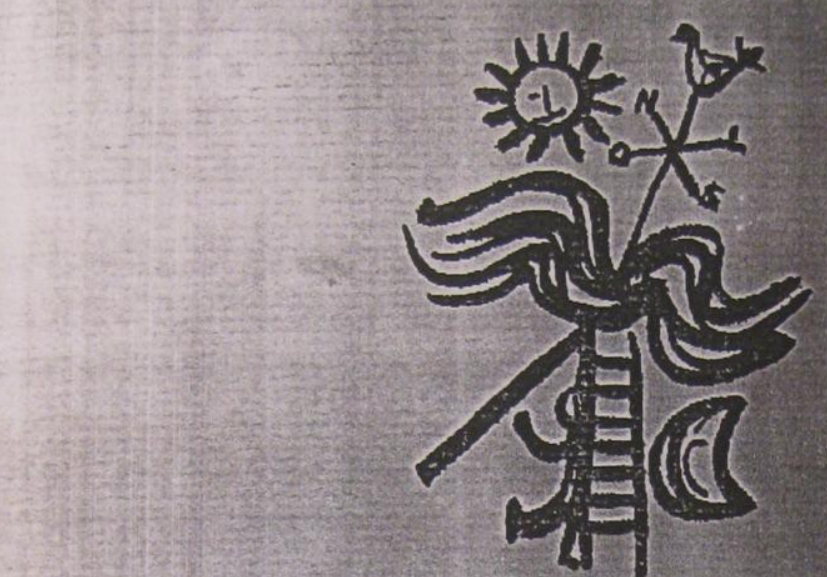

CURSO INTEGRADO DE TEATTRO E EXIPRESSÃO PARA ADOLESCENTES

Às $3^{\text {a }}$ feiras, das 14.30 às 16.30 h e aos sábados, das 10 às $12 \mathrm{~h}$. Processos de sensibilização, expressão e experimentação. Processos criativos a rtir do corpo e de outras linguagens. Experimentação de materiais, objetos, cor, rma e palavra. Linguagem orgânica integradora, que vem dos brinquedos popures, do boneco e da realidade em níveis poéticos, que permitem a utilização e o ggate das expressões dramáticas da infância, a reelaboração das linguagens musi-

cais e sintéticas, e as diferentes simbologias individuais e coletivas.

\section{OFICINA DE TEATRO}

PARA CRIANÇAS

\section{Aos sábados, das 10 às $12 \mathrm{~h}$.}

I oficina desenvolve um trabalho de processos imaginativos, onde o aluno lida com histórias no plano verbal e escrito, animação de objetos, animação de bonecos, dança, cor, luz e movimento, culminando em jogos de representação.

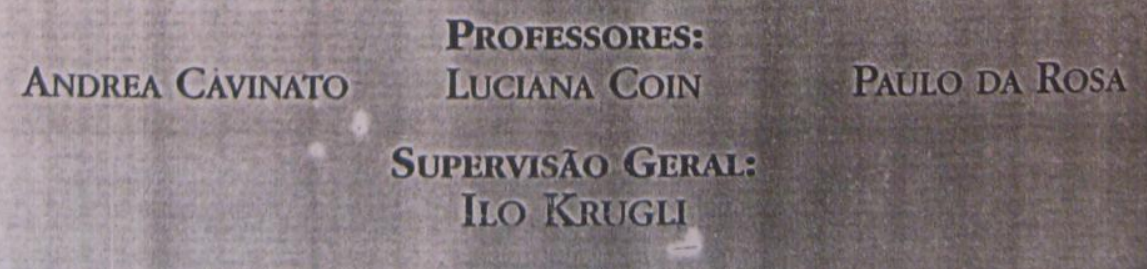

Folheto de divulgação de cursos. Arquivo Andrea Cavinato 


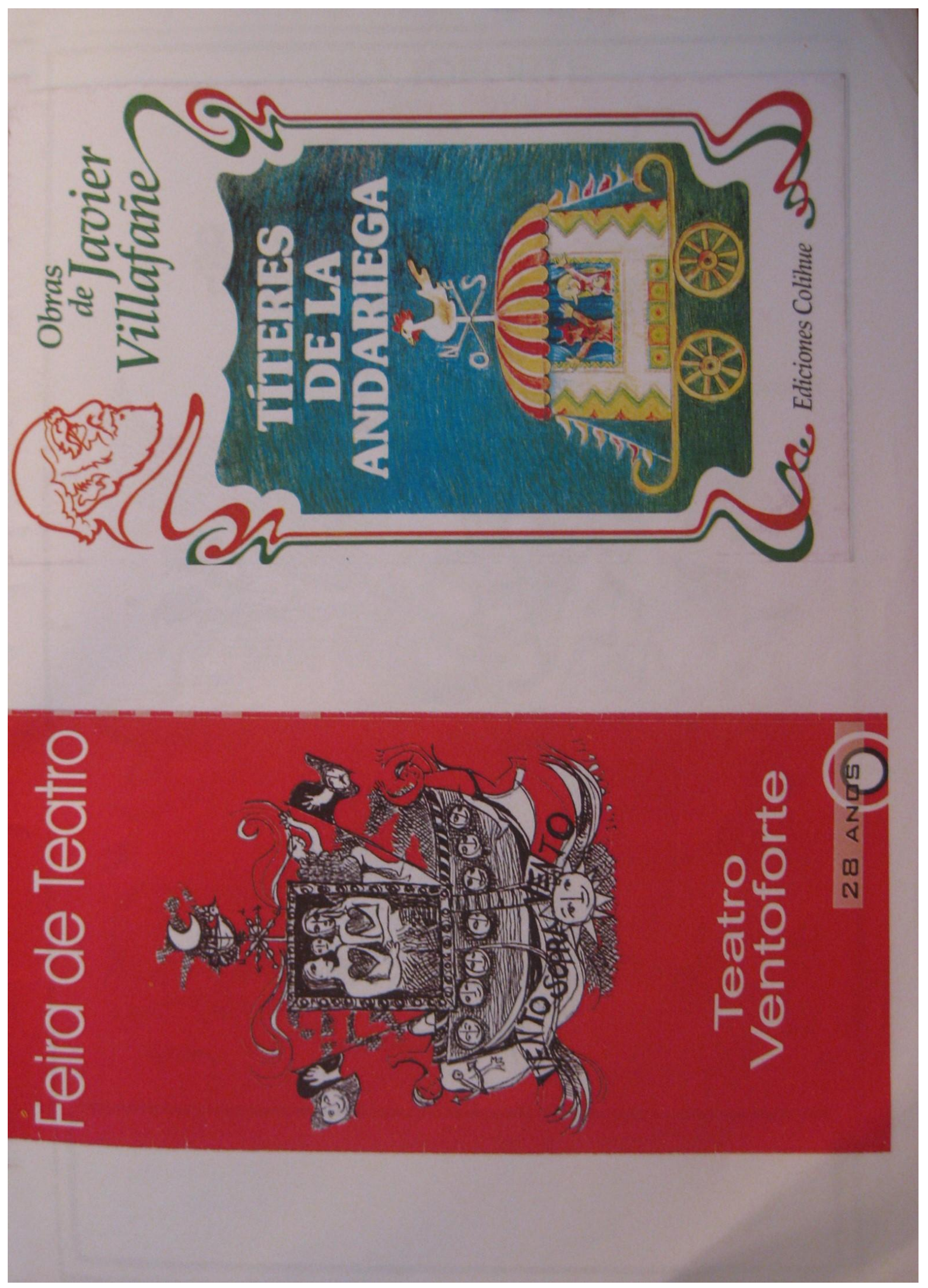




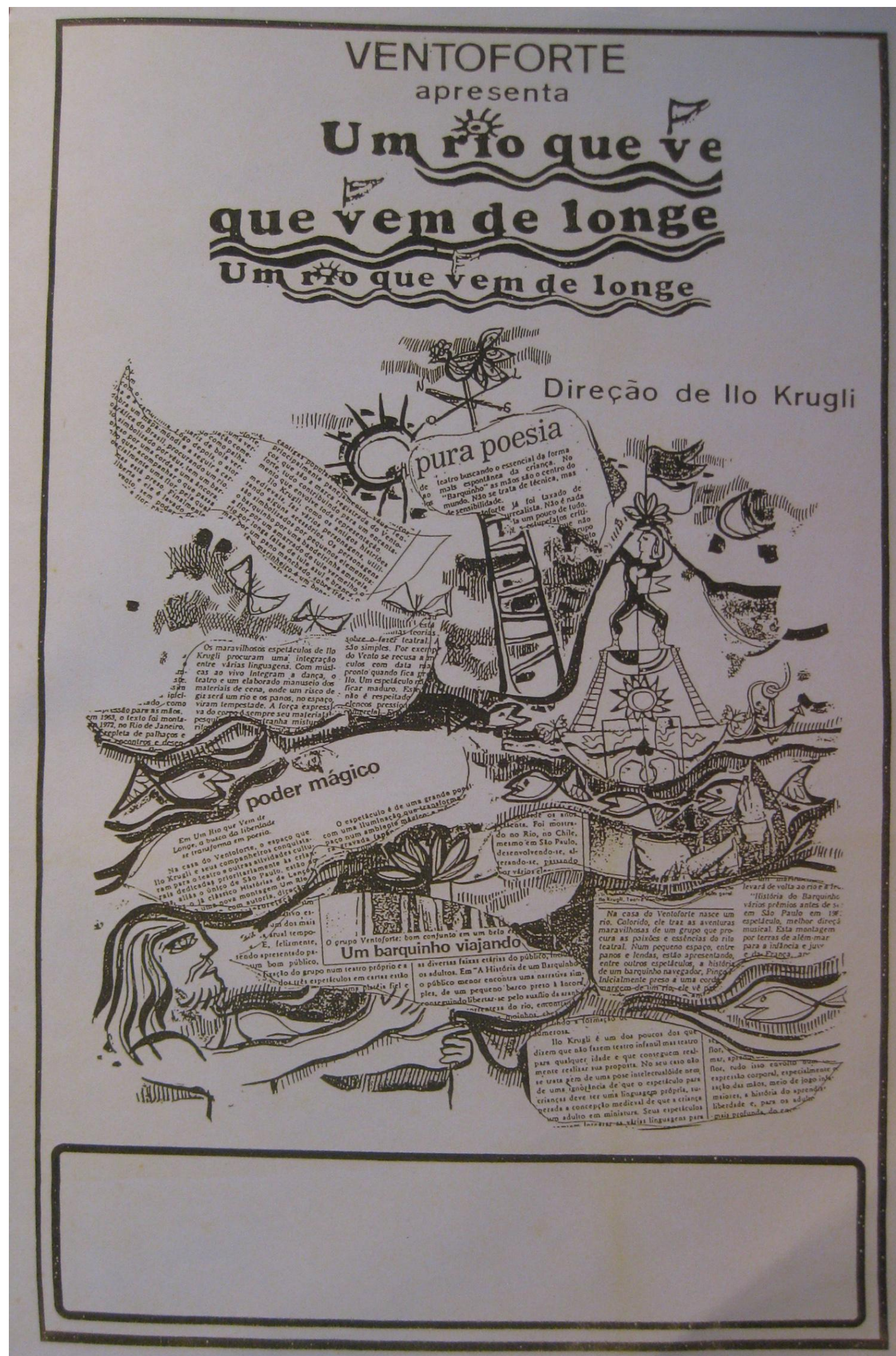

